

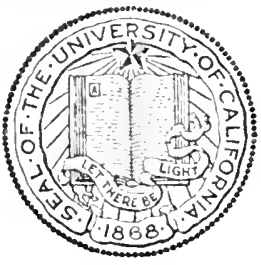

THE LIBRARY

OF

THE UNIVERSITY OF CALIFORNIA LOS ANGELES

\section{GIFT OF}

WAIDEAR WESTERCALRD 

Digitized by the Internet Archive in 2007 with funding from Microsoft Corporation 


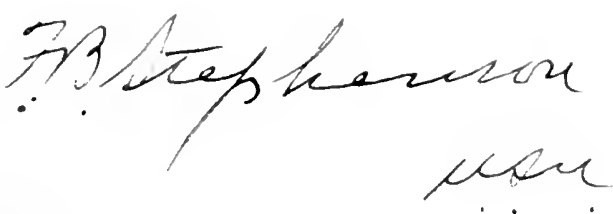

From

Tankin Bache blepunson bornmouder, lieclecul torpos

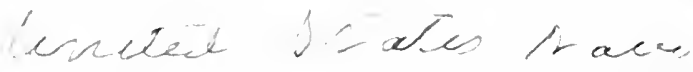




\section{.}




\section{A SHOR'T HISTORY}

OF

\section{ANGLO-SAXON FREEDOM}

THE POLITY OF THE ENGLISH-SPEAKING RACE

OUTLIYED IN ITS INCEPTION, DEVELOP.WENT, DIFFESION, AND PRESENT CONDITIOA

\section{$\mathrm{BY}$}

J AMES K. HOSMER

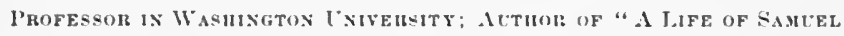

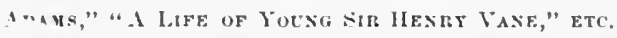

NEW Yolik

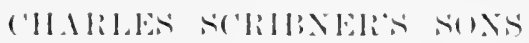


COPYRIGHT, 1890,

BY CIIARLES SCRIENER'S SONS. 


\section{Colloge \\ Library \\ JF51 \\ H79}

\section{P R E F A C E.}

Is this book an effort has been made to eompress a sketel of constitutional history for a period of nearly two thousand years, - from the time of the Teutons of Casar and Taeitus to the British Empire and the United States of 1890. It is not the polity of any single people that is outlined, but that of the English-speaking race, that body to-day perhaps one hundred and twenty millions strong, scattered in several nationalities aetnal or incipient, which upon all the continents and all the great islands of the world, stands now so in the foregroumd of attention. It is a polity one and the same in its essence in England, in the Uniterl States, in Anstralia, in Canarla: one and the same in its essence, moreover, as viewed in the institutions of to-day and in those of the North Germans of the time of C'hrist. As Sir Francis Palgrave says: "The new huilding has been raised upon the old gromulwork ; the institutions of one age have always been molelled and formed from those of the precerling, and the lineal descent has never been interrupted or disturbed." Anglo-sixon freedom is most simply and comprehensively stated in the phrase of Abraham Lincoln, "govermment of the people, ly" the people, and for the people." In its long history 
there have been periods of temporary submergence, adaptation to the needs of ever vaster multitudes and higher eivilizations, manifold development and elaboration : one spirit, however, has survived through all, apparent in the deliberations of a modern Congress or Parliament, as also it was apparent in the ancient folk-moots, where the free ceorls chose their army leaders and regulated the life in their marks.

While works upon the constitutional history, both of England and Ameriea, abound, they for the most part appeal, both as to style and size, rather to the scholar and the statesman, than to the general reader and the youthful student. Moreover, in such works it has too seldom happened that the constitutional history of the English-speaking raee has been regarded en solidarité: but in this way it is both proper and expedient to regard that history. England and America are mother and child; the polity of the latter in its origin is a mere outflow from that of the former, the two constitutional streams since the divergence flowing eonstantly parallel and mutually reacting. Our frequent eomplaint is that Englishmen fail to understand us; just so, we fail to understand them. Says the Westminster Review, for March, 1889: "England's sternest, coldest, most eritical eensors, I have found among descendants of the old settlers; surely they retain something of aneient Puritan bitterness. The souree of estrangement I am inclined to trace largely to the fact that the average Ameriean reads no history but United States history, and he ean hardly be said to study that." Certainly, to set right the "average Ameriean," and also the average Englishman, is a task worth essaying. There ought to be 
room for a book sueeinct and simple in its terms, which should tell to busy men and to youth in the elass-room, the story of Anglo-Saxon freedom; for as James Bryce has said: "It is a matter of the first consequenee that the relation to one another of the two branches of the English-speaking race should be more fully understood and realized."

In the exeeution of such a task the difficulties are not small. How to prescrve a proper historical perspective while viewing upon so reduced a scale such a multitude of events and figures? What guides to select in threading one's way through the long ages? 'There is no period through which one must not proeeed with care, and the embarrassments are perhaps as great with respeet to times close at hand as with respect to times remote. While this book was in preparation, the establishment of the Comnty Councils has restored to the English shires their ancient local self-govermment; since it was ready for the printer six Commonwealths have been added to the American Union; as it awaits its publication, an Anglo-Saxon protectorate extends itself more and nore widely over Africa, and the fecleration of Australia may heeome any month an aceomplisherl fact. These ale all events noteworthy in the history of Anglo-Saxon freedom, as are still others of which the newspapers weekly give report. How to eateh them accurately and in due proportion? - $\Delta$ s to remote ages, the dankness due to the remoteness is further deepened by the eontroversies of scholars. The employment of representation has commonly been held to be elaracteristic of Anglo-Saxon societies in the most distant epochs; but this honor is now denied to them by anthorities 
deserving of high respect, who find no good evidence of the existence of a representative system until after the Norman conquest. Mr. Frederic Seebohm, in his "English Village Communities," fails to see that the Anglo-Saxon invaders brought with them any freedom at all, as they set up their tuns and scires in their new home: in the settlements that were established a lord ruled as master, with a society under him in a condition of villenage; the free village community was by no means the type, but from the first a marked feudalism in which the mass of men were serfs.

Still more sweepingly, Mr. H. C. Coote, in his "Romans of Britain," will have it that the AngloSaxons transmitted to us not only no freedom, but nothing else. They were simply a horde of invading savages, exercising for a time dominion over a people they had conquered, who much surpassed them in civilization, - a horde which was at length annihilated by the Danes, leaving no trace of itself or its influence; for, thinks Mr. Coote, all that we have called Anglo-Saxon, in blood, tongue, or institutions, ought to be ascribed to a different stock, and has received the name only through mistake. - While at the two extremes of the subject embarrassments thus abound, certain intermediate periods are scarcely more free. In the English colonization of America, for instance, the extent to which the new country followed the precedents of the old is not a matter upon which all are agreed. The "new historical school," of which E. A. Freeman may be regarded as the founder, and of which the most characteristic publications in America are the historical and politi- 
cal tracts of Johns Hopkins University, edited by Prof. Herbert B. Adams, is inelined to trace in minute detail in American societies the usages of the old world, - a course for which it has been sharply censured, sometimes by seholars of reputation.

Under these cireumstances, if a time were ever likely to arrive when doubtful questions will be any less in doubt, it would be prudent to defer the execution of sueh a task as the present one until that time. What probability is there, however, that the mighty mareh of Anglo-Saxondom will in these ages, ever press less confusingly upon the eontemporaneous ehronieler; or that as regards the past, the discord of authorities will ever be harmonized? The task is worth exeeuting; the time as propitious as any that is likely to arise. The present writer, fortifying his juclgment as he could, has written his book, following the lead of the seholars most accepted. The mumerous footnotes will show, he trusts, that he has not been negligent in his reading. Ilowever open to question his conelusions may sometimes appear, they are not, at any rate, hap-hazard, but referable to respectable sorrees.

The witer desires to express his obligation to a number of helpers. He is indehted to Mr. Coldwin Simith and to Mr. James Bryee for letters expressing sympathy with the main idea he has liad at heart, to illustrate, namely, the substantial identity of the great English-speaking nations, in stork, and in the spirit of their social and political institutions, as well as in tongue: and the expediency that these nations should, in John bright's phrase, become one 
people. The writer has received such a letter also from the venerable Sir George Grey of Auckland, at different times formerly, governor-general of New Zealand, of an Australian province, and of South Africa, and in those high positions so honorably identified with the rise of an English-speaking world in the South Pacific. Dr. W. G. Hammond, Dean of the St. Louis Law School, Hon. Mellen Chamberlain, late librarian of the Boston Public Library, and Prof. W. W. Folwell of the University of Minnesota, have given the writer the benefit of their criticisms upon several of his ehapters, and helped him to important books which he could not otherwise have obtained. To Messis. Houghton, Mifflin, \& Co., owners of the copyright of the "Life of Samuel Adams" and "Life of Young Sir Henry Vane," the writer is under obligation, for permission to quote from earlier work of his own bearing upon the present subject. Finally, it must be mentioned that this History of AngloSaxon Freedom has been written at the instance of Mrs. Mary Hemenway, of Boston, and is to be regarded as an outgrowth of the work undertaken by her to promote good citizenship and love of freedom, known as the Old South work.

JAMES K. HOSMER.

ST. Lovis, September 21st, 1890. 


\section{TABLE OF CONTENTS.}

\section{CHAPTER I.}

Tine Prmitrye Saxons.

The polity of the United States to some extent a revival of something most ancient. - The plains at the mouths of the Eibe and Weser. - Social and legal aspects of the civilization of the Anglo-Saxons. - Divisions of rank. - Political forms. - Comparison of the Anglo-Saxon polity with that of other primitive Aryan peoples; with that of modern Anerica. - Freeman and J. R. Green on the retention of Anglo-Saxon elements in the constitutions of England and America .

\section{CHAPTER II.}

Tite Axglo-Sixox Coxquest of Britan.

Inquiry into the value cf Anglo-Saxon freedom. - Views of John Stuart Mill and J. Toulmin Smith. - Saxon conquest of Britain. - Transferrence of the continental civilization to the new home. - Appearance of kingship. - llow the King was appointed. - Origrin of the thegus. - Conversion of the Saxons to Christianity. - The IIeptarchy. The supremacy of Wessex. - Moots of tmo, hundred, and shire. - The witenagemote. - Conservative spirit of Alfred. - Influence of the Danes. - The ceorls sink towarl villeinage. - Incipient fendalism. - Elward the Confessor.

\section{CHATPTER III.}

ThF BatTh: OF Ilastregis.

Appearance to-day of the flele of Senlac. - Importance of the battle. - The beach at Hastingrs. - Ianding of the Yormans in 1066. - Appearance of Duke William. - Ilis pres- 
ence of mind. - Difficult situation of Harold. - Battle Abbey. - The " Roman de Rou." - The two armies opposed. - The minstrel Taillefer. - Dangerous situation of the Normans. - The wounding of Ilarold. - The rout of the Saxons. - A walk to-day over the battle-field . . .

\section{CHAPTER IV.}

Magia Charta and tile Rise of Parliament.

Submergence of popular government under fendalism. Ultimate good effect of the Norman conquest. - Character of the rule of William I. - Domesday Book. - Persistence of ancient institutions in tun, hundred, and shire. - Cliaracter of the King's title. - Limitation of feudalism in England. - Work of Henry II in depressing the great vassals. - The Curia Regis. - Serfdom. - Trial by jury. - Accession of John. - Runnymede. - Analysis of Magna Charta. - The work of Langton. - The origin of Parliament. Value of the representative system. - Conditions of its success. - Simon de Montfort and his achievement. - Edward I and the establishment of the House of Commons .

\section{CHAPTER V.}

The Coming UP of the Serfs.

Condition of freedom in Europe in the thirteenth century. Constitution of the early Parliaments. - Importance of the knights-of-the-shire. - The yeomen. - Unfortunate state of the boroughs. - The Chapter House at Westminster. - Division of Parliament into two Houses. - Growth of the power of Parliament. - Its imperfect character as a representative body. - Rise of the farmers and the free laborers. - The Statute of Laborers. - Peasant rebellion. - John Ball in Kent. - Bearing of Richard II. - Wat 'Tyler of Essex. - His death. - Treachery of the King. - William Grindecobbe. - Aristocratic temper of Parliament .

\section{CHAPTER VI.}

The Times of the Lancastrians.

Deposition of Richard II. - Power of Parliament under Henry IV. - Popularity of Henry V. - Fortescue on the English constitution. - Sudden decay of the power of Par- 
liament. - Misfortunes to representation in the shires and the boroughs. - Jack Cade's rebellion. - Justice of his cause. - The Wars of the Roses. - Extinction of the power of the nobles. - Accession of the Tudor line. . .

\section{CHAPTER VII.}

\section{Depressiox of tile Power of Parlanient.}

Great increase of the power of the Crown. - Effect of the Reformation in producing this. - Position and character of Henry VIII. - Good points of his reign. - Catholic reaction under Mary. - Wyatt's rebellion. - Parliament grows more spirited under Elizabeth. - Sir Thomas Smith's description. - Tact of the Queen-Acts of Supremacy and Uniformity. - Star Clamber and High Commission Courts. - Absolutism restrained under the Tudors. Its triumph everywhere upon the continent. - Growth of the doctrine of the jus divinum. - Cowell's "Interpreter." - Subserviency of Convocation and the University of Oxford. - Claims of Janes I.-Opposition of Parliament. - Accession of Charles 1. - The Petition of Right. - Laud, Strafford, and the policy of "Thorough." - Shipmoney

\section{CHAPTER VIII.}

\section{Settlemext of Ameirica.}

Charters of the East India and Virginia Companies. - Settlement of Jamestown; of Plymontl. - Reviral of ancient Anglo-Saxon polity in New England. - Submergence in lingland of the populat moots. - Methods of Puritan settlement in Now England. - The town-meeting. - Reproduction of contemporary England in Virginia. - The parish, the county, the cont of Quarter Sessions.Scene at the connty court. - Reasons for the contrast between New Fngland and Virginia. - The yeoman settlers of the former. - The ereat planters, the slaves, the poor whites of the South. - Disrepute of labor. - Virtues of the Virginia society. - Spirit of the IIouve of Burgesioes. - Condition of South Carolina of Maryland. - Foudalism in New York and Penusylvania. - The popular moot the 
primordial cell of Anglo-Saxon freedom. - Its condition in the Thirteen Colonies, its spirit in New England, its feebleness in the South

\section{CHAPTER IX. \\ The Exgland of Chardes I.}

Effort of Charles to rule without a Parliament. - The Short Parliament. - Assembling of the Long Parliament. - Its idea to establish the equilibrium between King, Lords, and Commons. - Arrest of Laud and Strafford. - The Grand Remonstrance. - Attempt to arrest the Five Members. Outbreak of the Civil War. - Constitution of the two parties. - Edgehill. - Low estate of the Parliament. The Solemn League and Covenant and Marston Moor. Naseby. - The rank and file of the Ironsides. - Their manifestoes. - Reluctance of the leaders to subscribe to them. - The prayer-meeting of December 22, 1647 . . 130

\section{CHAPTER X.}

\section{The Exglisil Comonwealth.}

Civil war of 1648. - Siege of Colchester and battle of Preston. - The Grand Army Remonstrance. - Resistance of Parliament. - Pride's Purge. - Ireton's declarations. The Agreement of the People. - Its antieipation of the Reform Bill of 1832. - Abolishment of the kingship and the House of Peers. - Execution of the King. - Republican ideas of the party in power. - Temporary government of the Rump and the Couneil of State. - Embarrassments of the Independents. - Cromwell in Ireland. - The campaigns of Dunbar and Worcester. - The ocean war with Holland. - Schism among the Independents. - The dissolution of the Rump. - The autocracy of Cromwell. Panegyric of Milton. - The Restoration. - Benefits secured by the English Revolution . . . . . 146

\section{CHAPTER XI.}

The Revolution of 1688.

Enthusiasm for Charles II. - Reaction from the ideas of the Commonwealth. - Benefits flowing from the bad char- 
aeters of Charles II and James II.-The nation foreed into resistance. - The Bill of Rights and the Revolution. - William and Mary. - Extinction of liberty elsewhere. Whigs and Tories. - Important part played by the nonconformists and commercial classes. - The Huguenots and other refugees.-Doubtful struggle between Whigs and Tories. - Establishment of modern forms in the polity. Rise of the Cabinet. - Unsatisfactory condition of Parliament. - l'ower of the nobles and men of wealth . .

\section{CHAPTER XII.}

Fra of Parlianextary Corruptios.

Equal responsibility of Whigs and Tories for parliamentary corruption. - Stooping of honest men to bribery. - Degeneracy of the comuty representation. - Decline of yeomen. - Assumptions of the great land-holders. - Bad eondition of the boronghs. - Destruetion of the popular franehise. - Rotten boroughs. - Their growth under the Tndors and Stuarts. - Large towns unrepresented. - Cases of Buckingham, Bewdley, Oxford, Salisbury, Bath, New Shoreham, Sudbury. - Condition of Scotland. - Case of the shire of Bute. - Price of seats in Parliament. - The " nabobs." - Testimony of Sir Samuel Romilly. - The people unrepresented. - Case of Wilkes. - Mass-meetings. lise of the great newspapers. - Dangers to freedom

\section{CHAPTER XIII.}

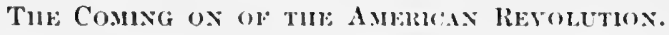

Condition of the Thirteen Colonies in the first half of righteenth century. - The approach of the American kerolution. - The title to the colonies in the Crown, not in the Parliment. - Inconsisteney of Kings and colonists. The ecclesiastical yrieranee. - The commereial grievance. - Selflshess of the trading-spirit. - The Sugar Act. The rights and privileges of Englishmen. - Effect of the destruction of Funeh power. - Fuforeenent of customs regulations. - The Writs of Assistance. - The Stamp Act. - Dehafe in Parlianent. - Burke, Chatham, Camden. Mansfleld. - The yltestion smmed up. - Superior appre- 
ciation by American statesmen of Anglo-Saxon freedom.

- Leadership of Massachusetts . . . . . . 192

CHAPTER XIV.

The Americay Revolution a Struggle of Parties, NoT Countries.

Character of George III. - Sympathy of Englishmen with the American struggle.-A strife on both sides of the ocean. - Ability and number of pro-American advocates. - Fear for English liberty if America was conquered. Position of Burke. - The masses pro-American. - Strength of Tories in America. - Their wealth and position. Their expatriation. - Pathetic circumstances of their story. - Victory of the popular party on both sides of the Atlantic .

CHAPTER XV.

The Constitution of tire Uxited States.

The written Constitution a unique feature of the American polity. - In England Parliament completely unfettered. Importance of the written Constitution. - History of the idea. - A germ of it in Magna Charta, in guilds of Middle Ages. - Charters of trading-companies. - Social compact of the "Mayflower." - Connecticut precedent. - Vane's "Healing Question." - Convention of 1787. - It proceeds upon English lines. - Careful retention of Anglo-Saxon forms. - Contrast between constitution-makers in America and elsewhere. - Local forms unchanged. - The President the English King of the eighteenth century. - The Electoral College borrowed from Holy Roman Empire. - The House of Representatives compared with the Commons, the Senate with the House of Lords. - The Supreme Court. Influence of Montesquieu's " Esprit des Lois." - Sir Henry Maine's admiration of the Constitution

\section{CHAPTER XVI.}

The New Colonial Empire axd the ReFory BIll OF 1832.

French anticipations of England's ruin at close of American Revolution. - How they were frustrated. - Why Canada 
did not join the United States. - Voyages of Cook. - Distinctions to be made in the present colonial empire of Britain. - India, the West Indies, Canada, South Africa, Australia. - Pitt's agitation of parliamentary reform.The "Friends of the leople."-General sympathy with French Revolution in its early stages. - Reaction on account of the Reign of Terror. - Cessation of the reaction at Waterloo. - Agitation for reform. - Passage of the Reform Bill of 1832. - Good effects of passage of the bill. - Present shape of English polity. - England practically a republic. - Adequacy of the people to their responsibilities. - County Couneils of 1888. - Ilenry George's scheme of reform. - Flexible and rigid constitutions. l'itt's colonial bill of 1791 . - Freedom of Greater Britain. - Colonial Fxhibition of 1886. - Fxtension of Anglo-Saxon freedom to other countries. - It must be administered by Anglo-Saxon men

\section{CHAPTER XVII.}

\section{Present Condmion of the American Polity.}

Permanence of the Federal Constitution. - Distrust of legislatures as indicated by the State constitutions. - Condition of the primordial cell of an Anglo-Saxon polity, the popular moot. - Examination of rural Ameriea. - Loeal self-government in New England. - Intluences which impair the eharacter of the town-meeting. - Picture of it thirty years since. - Tributes to its value. - Settlement of the West. - Ordinanee of $178 \pi$. - Loeal self-government in Ohio, Michigan, Illinois. - The Township-Connty system of the Northwest. - The County system of the Sonth. - Virginia continues to be typieal of the South. The Township-County system the perfect type. - Fxamination of urban America. - Growth and multiplication of cities. - Their government the most conspicuons failure of the Lnited States. - Fagerness to remedy the abuses. - Views of Hon. Seth Low. - No reason for discourage. ment 


\section{CHAPTER XVIII.}

The Future of Axglo-Saxon Freedom.

Predictions of its wide dominance. - Views of J. R. Green, F. B. Zincke, Gladstone. - The blood of the English-speaking race still pure, though enriehed by foreign admixture. - Views of F. A. Freeman, Matthew Arnold, R. A. Proctor, J. Bryce, Sir Edwin Arnold. - Identity of English-speaking men as illustrated at the Colonial Exhibition of 1886. - The stock never stronger or better than now. The troubles that beset it. - Dangers from intemperance, licentiousness, neglect of public education. - The French question in Canada; fear of the Chinese in Australia; Home Rule in England; in $\Lambda$ merica the negro question, excessive immigration. - The embarrassments not especially formiclable as compared with those of other times . . . 308

\section{CHAPTER XIX.}

Do We Respect our Freedom?

The celebration of April 30th, 1889. - The people's love of Anglo-Saxon freedom. - Testimony of Andrew Carnegie; of J. Toulmin Smith. - The American and the German. Value in politics of the instinct of the plain people. View of J. Bryce, of Lecky, of Addison, of Motley, of President C. W. Eliot of Harvard. - General confidence of high and low in our freedom . . . . . .

\section{CHAPTER XX.}

\section{A Fraternity of Exglisit-Speaking Men.}

The idea of an Anglo-Saxon brotherhood. - Views of J. R. Seeley, of John Bright, of Sir Henry Parkes, of Sir George Grey, of J. C. Firth, of the Westminster Review, of the New Zealand IIerald. - Australians especially cordial to the idea. - Indifference of Americans. - Reasons for cultivating fraternal feelings among English-speaking lands. - English readiness to admit and make good past mistakes. - Sir Edwin Arnold's plan of an International Council. - Necessity of doing something to prevent AngloSaxon traditions from becoming obscured. - Need to the 
world of Anglo-Saxon leadership. - Possible perils from China; from Russia. — Sketch of Russia. - Threatening character of her vast development. - Lessing and Goethe on the virtue of patriotism. - Love for lumanity ligher than love of country. - Blessings of unification. - For the abrogation of national distinetions like must first seek like. - An Anglo-Saxon fraternity a step toward the "federation of the world". . 343

\section{APPENDIX.}
A. Mafisa Chimet 1215. . . . . . . 371
B. Petition of Rigitr. 1628 . . . . . . . . 383
C. BIt. of Rigits. 1688 . . . . . . . . . . . 386
1). Coxstitution of the Unitein States. 1787 . . 394
F. Cosititution of Canad, 1867 . . . . . . 399

INIDEX . • . . . . . . . . . 403 
"It is a matter of the first consequence that the relation to one another of the two branches of the English-speaking race should be more fully understood and realized."

JAMES BRYCE.

"The new building has been raised upon the old groundioork; the institutions of one age have always bcen molelled and formed from those of the preceding, and the lineal descent has never been interrupted or disturbed."

Sir Fraxcis Palgrave: English Commonwealth, I, 6. 


\title{
ANGLO-SAXON FREEDOM.
}

\author{
CHAPTER I. \\ THE PRIMITIVE SAXONS.
}

100 B.C. -449 A.D.

ON the 30th of April, 1789, Washington, as the first President of the United States, took a solemn oath to maintain the Federal Constitution. The Deelaration of Independence had been made fourteen years before; the Revolutionary War had been fought through; the Constitution painfully formulated, and after the most anxious fears, ratified. The first elections had been held in due form. 'The ship of state had been built and launched. One last anxious moment remained, when, for the first time, steam was turned into the new machinery. Would the contrivance work that had been set in order with such pains? As Washington took the oath, the pulsations began of the mighty engine whose accomplishment through the hundred years need not here les reliearsed. Government of the people. by the people, and for the people, went into opreation, a thing at that time unknown elsewhere anong civilized nations. 
Unknown elsewhere; but had the world never before seen anything like it? As a polity, it was no The polity of original device, but a revival of something America to most ancient. I once crossed the North Bome extent of something most ancient. Sea, and coming upon deck after a night of storm, found the ship entering a great river, out from which rolled masses of ice. From the deck a monotonous, far-extending landscape could be seen, dotted here and there with compact red-roofed villages. Once landed, it was a journey of many leagues before the broad plains were left behind, and we reached a country more picturesque. If, however, the plains near the mouths of the rivers Weser and Elbe offer little attraction to the eye, no land is more interesting through its associations to the mind; for here lay the primeval home of the Angles and Saxons, with their kindred, the Jutes, just north, the remote forefathers of the imperial race which, now one hundred and twenty millions strong, retains substantially the language, institutions, and blood of those ancestors after the lapse of nearly two thousand years. In the ancient villages we can see distinctly a life proceeding, in some of its features, similar to that of English-speaking men at the present hour. ${ }^{1}$

The forefathers were not utter savages. Although fieree fighters, they were at the same time busy fisher-

Social and legal aspects of the civilization of the Anglo-Saxons. men and farmers. Though hard drinkers, the scenes within their homes were often not without a simple dignity, as the earl's wife with a troop of maidens bore the bowl

1 Tacitus: Germania, XI. Constitutional Histories of Stubbs, Free. man, Gneist, Taswell-Langmead, Hannis Taylor, etc. Von Maurer: Mark-verfassung. Waitz: Deutsche Verfassungsgeschichte, Band I, 4. 
of ale or mead about the hall while the minstrels sang. ${ }^{1}$ They possessed the runic alphabet, and showed in dress and arms an appreciation of the beautiful. The freeman in times that soon follow wore a smockfrock of coarse linen or wool falling to his knees, identical almost with that of the modern English ploughman. While it was the common garb of all classes, it was among those of good station handsomely embroidered: about feet and legs were wound linen bands, parti-colored. In winter, a hood covered the head, and over the shoulders was thrown a blue cloak, sometimes fastened by a costly clasp. For their constant warfare, the coats of ringed mail that were necessary, the swords scored with mystic runes while the hilts were finely wrought in silver and bronze, the helmets with heads of boars, wolves, or falcons for crests, - all made plain the skill of the smiths. In the society all the ceorls, or land-owning freemen, stood equal; they were bound together in families in such a way that if one underwent an injury, all his kin lay under obligation to exact reparation; as also they lay under obligation to afford reparation, if one of their number had inflieted the injury. Each elan oecupied its own mark, or village, a trict helil by the oecupiers in common. The homestearls within the tun (the storkate, quickset hedge, or protecting circle of earth) were lteld in severalty,

Phillips: Feschiehte dres Angelsächsischen liechts. J. Toulmin Smith: Iocal Self-Government and Centralization, p. 24:, etc. Johns Jlopkins University stullies, Ist Series, 1, II. J. R. (iren) Histury of the linglish People, Vol. I, Chap. 1. Howarl: Introduction to the laceal cunstitutional llistory of Lnitol states.

I See J. R. Green's graphic pieture at the begiming of the llistory of tho English People. 
modified, however, by a reservation of public rights; but the pasture and forest, stretching far, since wealth lay largely in flocks and herds, and since a good provision of wood was necessary for the winter, were free to all inhabitants. Between the homesteads, on the one hand, and the pasture and forest, on the other, was land the tenure of which was intermediate in its character. Such was the plough-land upon which each ceorl raised food for his household and cattle, but was under restrictions imposed by the community; such, too, was the meadow, which individuals owned from early spring to the time of the hay-harvest, but which through fall and winter was common feeding-ground for the swine and kine of all.

As to station, though in a primitive village of the Angles and Saxons the ceorls formed the most nuDivisions of merous class, they by no means comprised rank. all the people. There were besicles the lats, in some districts descendants of the race from whom the soil had been conquered, in other districts later comers than the Saxons themselves. The læt had no individual holding within the tun, and no share in the common land of the mark. He was dependent upon some ceorl, was to some extent restricted in his freedom, but at the same time possessed rights which the ceorl was forced to respect. Below the lats were the theows, men and women who were distinctly slaves, - captives in war perhaps, or persons fallen into this condition through debt or crime. The theow had no rights, his master having power over him for life or death: his children were born slaves; so, too, the children of a slave mother, though the father might be free. The theows were 
probably few in number. As at the bottom of the Anglo-Saxon social system the slave is found, so at the top stood the eorl, atheling, or noble, who, however, had no station apart from the ceorl. He was simply the man descended from the first settler, or the man set apart "because the blood that ran in the veins of all was believed to run purest in him." 1 But no power sustained him in his foremost place, except a free recognition on the part of his fellows that it was his due.

In the public life of the tribe the theow had no part, the laet little part; for the ceorl, by virtue of his possession of the land, held all power. Political In the centre of the tun was the moot-hill, forms. or perhaps a great tree, where the freemen came together to deliberate and to govern themselves. Here was administered the business of the common pasture and forest; here the grass-land was portioned out in the early spring, and the plough-land equalbly allotted. In case of a change in the private holding, the seller handed to the buyer a turf or a twig ent on the ground in question, in token of the transfer. As time proceederl, the tie of kinship gave way to the tie of neighlorhood, but the customs did not chlimge. As to the territory, there reminined the individual holding, the common, and the land hedel by intermediate tenure; as to the people, ceorl, lect, theow, aetheling, retained each his plitce. Above all. the moot remained the eentre of life in the mark. It is probable, ton. that here took place, after matters peculials to the little community were disposed of, the choosing of 
the representatives, who were to speak for those who sent them in the larger moots of the hundred and the folc. ${ }^{1}$

For before history begins, a series of moots ranging upward from the assembly of the mark in ever-widening comprehensiveness had come to pass. Marks were gathered into hundreds, districts sending, each, perhaps, one hundred men to war; and these again into the great tribe, or folc. Each division had its proper moot, the marks appearing probably by their representatives in the higher moots. On great occasions, and also at stated times, as at the solstice, the freemen gathered in thousands to the great folc-moot, dispensing with representation. The priests proclaimed silence and maintained order. Speakers were at liberty to persuade, but no one had power to command. The nation, which, upon occasion,

1 That representation appeared very early is asserted by the latest constitutional historians in general, - by none more confidently than the greatest among them, Bishop Stubbs (Constitutional History, Vol. I. pp. 44-45, 90-91, 95-96, 102-103, 114-115). There are profound and accnrate scholars, however, who see no adequate proof of it. Dr. W. G. Hammond finds no sufficient evidence as to the presence of representatives in the shire-moot until after the Norman Conquest, when, accorling to the laws of Henry I, the reeve and four men of the town appear, if the lord and steward are $a^{2}$ to remove the liability to fine of the unrepresented community. Dr. Hammond's views have been given in lectures in the law-schools of the State universities of Iowa, California, and Michigan; also of Boston University and Washington University, St. Louis. It is to be hoped that they will sometime be accessible to students in general in book form. My own examination of the passages in the Anglo-Saxon laws (Schmid: Gesetze der Angel-Sachsen, Leipsic, 1858) cited by Stubbs in support of his claim, leads me to feel that we must proceed here with cantion. However, the presence of the representatives of the tuns in the higher moots at a very early day is referred to in this book as a thing probable, - a position amply justified by the statements of those regarded at present as the greatest masters in this field. 
became at once a military host, sometimes opposed by loud shouts, sometimes approved by shaking their spears, while in vehement moments they clashed together weapon and shield. No functionary was recognized, except as he was elected by the national voice. No one was King, except as his title was based on the suffrages of the freemen. To lead armies, certain heretogas, herzogs, dukes, were selected and commissioned, usually out of the class of athelings; and these, if they became popular and redoubtable, had each his gesith, comitatus, a troop of spirited youths anxious to gain glory and booty, who attached themselves voluntarily to the successful chief.

If we compare this primitive polity of the AngloSaxons with that of other rude societies of the Aryan stock, some marked differences may be comparison noted. The power of the people, incleed, of primitive is no greater than in the Slavouic mir, or polity with is no greater than in the Slavonic mir, or that of other village; than in the communities of the ples. early Greeks, as described by Homer; than in the vilage communities of India. Inallan claims that all races oceupying a similar stage of culture possess a similar liberty. ${ }^{1}$ As regards the Slavs, however, the succession of moots above that of the mir is satid to be quite wanting. In the case of the Greeks, no such reengnition of the prineiple of representation existed, if we may trust Freeman," as that implied by the sending to the superior assembly of the spoliesmen for the mark. If we look at the village commmities of India, though in many of these a representative

1 Middie Ages, p. 6t, Harper's ed. See also G. L. Gomme: English Village Communities, Chap. I (18:0).

2 History of Federal Goverument, II, p. ti. 
council, standing for all the cultivators, exercises the government, nothing is to be found like the folkmoot, the general meeting of the people. ${ }^{1}$ Between the Anglo-Saxons and the Teutons south of them, a close analogy in institutions undoubtedly existed. The latter, however, though never conquered by Rome, became at an early period more or less affected by the Roman contact, and lost some of the primitive characteristics. Of all the Germanic tribes, the Angles and Saxons were those least touched by the influences streaming so abundantly and pervasively from the city of the Seven Hills.

Let us now set side by side ancient Germany and modern America, the ancient prolific mother and the

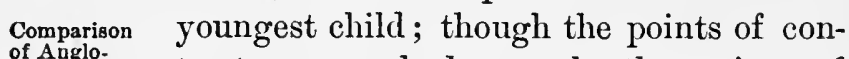
of Anglo-
Saxon with trast are marked enough, the points of Anerican intutions. resemblance will be found at the same time numerous and striking. A nation of sixty millions is vastly different from a tribe of a few thousands; the elaborate civilization of the nineteenth century is vastly different from the culture scarcely raised above barbarism, of the first; the intricate enginery of peace and war, the cities of iron and granite, the network of conventionalities by which we are bound, are far removed from the simple spear and shield, the palisaded tun, and the artless etiquette of the hall of the ætheling. Here are points, nevertheless, in which we agree with those men of the past. The first English settlers of America held their property by similar tenures, traces being by no means absent of the primeval communal system.2

1 Sir H. Maine : Ancient Village Communities, pp. 124, 154.

2 Johns Hopkins University Studies in History and Political Science, Ist Series, Nos. II, IX, and $\mathrm{X}$. 
The Indian, descendant of the aboriginal owners of the soil, without citizenship, yet not a slave, has been in some times and places probably, no remote analogue of the lat; so, too, the indented servant, a class numerous in the colonial days, who were bound in service to the freeman, and yet not distinctly servile. The slave, the counterpart of the ancient theow, we have had until within twenty-five years. As regards the theling, the man in a vague way set apart, likely to be chosen, if brave and competent, to the office of heretoga, or war-ehief, our society furnishes no trace of him; on the other hand, the American citizen, sovereign in all his privileges, is the counterpart of the ceorl, except that a share in the ownership of land is no longer a condition of the franchise. In the definite subordination, moreover, of tun to hundred, of hundred to shire, and of shire to tribe, we have no remote foreshadowing of town, county, state, and federal union. The New England town-meeting is the moot of the Anglo-Saxon tun, resuscitated with hardly a circumstance of difference; ${ }^{1}$ as closely parallel, perhaps, also are the ancient moots of the shire, if they were constituted of the representatives from each tithing, to the eounty boards of the Northwest made up by the supervisors of the different townships. ${ }^{2}$ Representation, the principle that pervades the whole apparatus for law-making and administration in the higher ranges of politic's, is distinctly an Anglo-Saxon idea, proceeding probably from the earliest times. If $A$ merica resembles the aneient

1 Freeman: Johns Hopkins I"niversity Studies, 1st Series, I, p. is.

2 Iloward: Introduction to Local Constitutional History of the Lnited States, 1, [1. 158. 
mother, in no less degree does England resemble her. "The voice of sober history does assuredly teach us that those distant times have really much in common with our own, much in which we are really nearer to them than to times which in a mere reckoning of years are far less distant from us." " "All England," Freeman and says J. R. Green, "lay in that oldest home, Freeman and
rreen on the
retention of in the village-moot, Parliament; in the retention of
Anglo-saxon
elements in glee-men, Chaucer and Shakspere; in piratethe constitu- bark, Drake and Nelson." All America lay
tions of Engtaons of Eng-
land and
America.

fibre of the whole great English-speaking race, in fact, is derived from those Elbe and Weser plains; government of the people, by the people, for the people, which is as the breath of its life wherever that race may be scattered, is the ancient AngloSaxon freedom.

1 Freeman: Growth of English Constitution, p. 158. 


\section{CHAPTER II.}

THE ANGLO-SAXON CONQUEST OF BRITAIN.

449-1066.

Oun freedom, then, is no new thing, but developed from the aneient Anglo-Saxon freedom, something transmitted from times perhaps prehistoric. We are to trace its course through nearly two thousand years, from the German plains to the United States of to-day. The fluetuations in its history lave been extreme and constant. Many times it has been upon the verge of extinetion. Always, however, it has been maintained, until at the present hour it advances to the dominion of the world.

But before entering upon the story of this progress, let us inquire precisely why Anglo-Saxon freedom must be regarterl as ralnable. Precisely why is it that in an intelligent the value of human society it is letter that the people freedom. should govern themselves than that they should be under mastership, either that of a sovereign or at ruling clasis, however wise and well disposed? Since human nature is what it is, it is quite certain that in the long run peace and justice between man and man will be better lorought to jass through selfgovernment, in a civilized state whose ritizens are 
fairly self-controlled, than through a monarchy or the rule of a few. Now and then a King arises of the highest good sense and the utmost worth. Sometimes a small governing class will show, through a term of years, unselfishmess and solieitous skill in public business. The beneficent autocrat is sure, however, to give way sooner or later to some tyrant - the well-meaning few to a grasping oligarehy. The masses of mankind can trust no one but themselves to afford to their welfare a proper oversight. No one will claim for demoeratic government that it is not beset by embarrassments and dangers. Its course is always through tumults; its frictions under the most favorable circumstances cause often painful jarring and obstruction. But when all is said against it that can be said, it remains true that, for Anglo-Saxon men, no other government is in the long run so safe and efficient.

There is, however, a more important consideration than even this in favor of government of the people, View of John and here I cannot do better than follow stuart Mill. the thought of John Stuart Mill. The best government is that which does most to improve the people, and that is the government in which the supreme controlling power in the last resort is vested in the entire aggregate of the community, - every citizen not only having a voice in the exercise of that ultimate sovereignty, but being, at least occasionally, called on to take an actual part in the government by the personal discharge of some public function, local or general. The superiority of popular government over every other as to effect upon character is decided and indisputable. The practice 
of the dicastery and ecclesia raised the intellectual standard of an average Athenian citizen far beyond anything of which there is any example, either ancient or modern. A benefit of the same kind is produced upon Englishmen and Americans, by their liability to be placed on juries and to serve in town, district, and parish offices. They are thus made very different beings in range of ideas and development of faculties from those who have done nothing in their lives but drive a quill or sell goods over a counter. Still more salutary is the moral part of the instruction afforded when private citizens take part in the public functions. They must weigh interests not their own, and be guided by another rule than their private partialities: they must regard the general good. Participation, even in the smallest public function, is useful: such participation should, however, be great as the general good will allow; nothing else ean be ultimately desirable than the admission of all to a share in the sovereign power of the state. Unless substantial mental cultivation in the mass of mankind is to be a mere vision, this is the road by which it must come. De Tocqueville has shown the close connection between the patriotism and intelligence of Americans and their democratic institutions. No such wide diffusion of the ideas, tastes, and sentiments of edueited minds hits ever been seen elsewhere, or even eonceived of as attainable. Nothing quickens and exprunds like politieal discussion; but politieal diseussions fly over the hearls of those who have no votes and alre not endeavoring to acpuire them. Their position in comparison with the electors is that of all atulience in 
a court of justice compared with the twelve men in the jury-box. 1

To these views of Mill may be added those of another energetic writer. Popular government af-

Views of J. Toulmin fords the only true education. It is not Smith. schools and colleges that can ever give that education. They may be the means of imposing cramps and fetters on the mind; they may dull out half the faculties by giving undue exercise to others; they may drill into a lifeless routine of proprieties and conventionalisms ; they may even impart what is called refinement and politeness; but they never are, and never can be, the means of training up to the great business of life. For that a greater and wider school is necessary, - the school of the active exercise of all the faculties in the earncst work of real life. But the great instrument for drawing forth the powers of mind and sharpening the wit in every useful way will be the free schools of manly discussion and intercommunication which popular institutions will keep always open and attended. Both as to thought and action, the faculties of man will have this as their best training. Men cannot discuss without first having paid some attention to the subject-matter of discussion. As long as everything is done for them, they have no occasion to think at all, and will soon become incapable of thinking. But the moment they are thrown on their own resources, the moment selfreliance and self-dependence are made necessary to their existence, they wake from their torpor, put forth their energies, and rouse their faculties. It becomes

1 Considerations respecting Representative Government, American ed., p. 62 , etc. 
necessary that they should act; and to act they should think. ${ }^{\mathrm{I}}$

If, then, Anglo-Saxon freedom is a matter of such paramount importance, time will be well spent in tracing its course in history. It has been seen that a considerable similarity exists among the popular institutions of the primitive Aryan stocks, a similarity extending in some degree to savage races in general. No such development, however, has anywhere else taken place as that in the ease of Anglo-Saxon freedom. The English-speaking ruee is the only race in which there has been an unbroken institutional growth from the forest beginnings. "No other society," says Macaulay, "has yet succeeded in uniting revolution with prescription, progress with stability, the energy of youth with the majesty of immemorial antiquity." 2

In the conquest of England there was a complete transfer to the islind, of the continental order. Veritable war-keels of the times of Hengist aud Horsi have been preserved in the peut- Anglo-Saxon and Horsia have been preserved in the peat- conquest of bogs of Sleswick, so that an acenuate islea may be formed of the fleets in which was effected this memorable deportation. They were flat-botomed, so that they might be easily bear-hed, seventy feet in length, eight or nine in width, with sides of oak planks fastened ly bark ropes and iron bolts. lice-

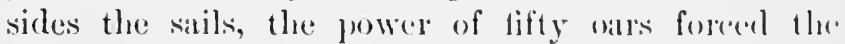
dragon figure-hearl thromgh the seit. Along the but-

1.J. Toulmin Smith: Incal Self-(iovermmunt and Centralization, London, J. Chapman, 18j1, 1. 50 , ete.

2 History of Eingland, Vol, I, 1. 20, Harper's ed. 
warks were ranged the war-boards, the round shields of the crew, of yellow limewood, with an iron boss in the centre. In the holds of the preserved ships have been found still lying the weapons and armor held ready for the landing, - the short seax, at once dagger and knife; the sword, with its blade runeinscribed; the long spear of ash; the falcon or boarcrested helmet. In the effete Roman world upon the border of which they had lived, scarcely touched by influences from it either good or bad, the basis of society was the peasant crushed by deepening fiscal tyranny into the slave ; the basis of political life was the hardly less enslaved proprietor, disarmed, bound like a serf to the soil, powerless to withstand the greed of the government in which he himself had not the slightest part. ${ }^{1}$ The society and polity with which those rude barks, breasting far and near the bleak German Ocean, were freighted, was, on the other hand, that of freemen, brave ceorls, judging, fighting for themselves; farmers and herdsmen by land, by sea the boldest of sailors.

After the foray of Jute, Angle, and Saxon warriors, wife and child presently followed; just as distinctly

Transference of the continental civilization to the new home. in the transplantation passed retheling, ceorl, læt, and slave, who presently set in order tun, liundred, and shire, each with its appropriate moot. ${ }^{2}$ The movement has

1 J. R. Green: The Making of England, p. 148.

2 It must be noted here that there are scholars who find no evidence of such a transference of life and institutious from the Elbe and Weser plains to Britain, at the time of the Anglo-Saxon conquest. Mr. H. C. Coote in his "Romans of Britain" (London, F. Norgate, 1879), argues at length, that during the Roman period the greater part of the island was occupied by the Belgae, who had begun to settle here before the 
not the attestation of documents, but, comparing the account of Tacitus with the reports of ammalists who after an interval appeared, the intermediate history becomes plain to us. As before, the land-owning freemen possessed all substantial power; the unit of the political body was the tun-scipe, township; and this, whether it was a settlement of kindred colonizing on their own account, or the estate of some rich man occupied by a body of dependents, or a neighborhood of small landholders brought to act together simply from their nearness to each other with no tie of relationship, possessed a vigorous vitality. In exeeptional cases the reeve of the tun was not elected, but nominated by the great proprietor; nevertheless, in all the tuns the ceorls had their moots with power

time of Cresar. They were Tentons, and to them we owe what we have called the Anglo-Saxon element in our institutions and langrage. When the Anglo-Saxons eame, they did not exterminate, but lived anong the Romanized population (the Belgar, namely, who had risen in civilization under the masters from the Seven IIills), as conquerors and controllers, though in a far more barbarous condition than their victims. The institutions and language that prevaled were derived entirely from those lomanized belgie: for the Anglo-Saxons were at last all killed by the lanes. Then the "Romau burgesses" came up, obtainiug concescions almost amonnting to independence. Through intluenees proceceling from then, fetclalism was overome, aul a place in the national conncil at last won for the Commons, this last achievement being hut the revival of a right which had been jossessed under the Roman empire. These ideas, so at variance with the ordinary tea bhing as regards early English listory, are presentel with much learning aud ingenuity. They have male upon the world little impression, however, and since the death of Mr. Coote, in 18sa, thay have fombl no conspirinoms ehampion. The vast weight of anthority remains in favor of the view stated in the text. Severtheless, the fact that a theory so utferly sulversive of this view almits of a presentment so plausible, must canse a feeling that here statements quite too definite may be made, and that the margin of meertainty, as regardsevents in these dark years, is very large. 
of making their local laws. The burh, or borough, was only a more strictly organized tun-scipe, with a ditch or rampart of eartl instead of the hedge or paling. The hundred, or wapentake, was a union of townships. These again were collected into divisions called in the North ridings, in Sussex rapes, in Kent lathes; the shire at last comprehended all, the chief officers of which were the shire-reeve, and the ealdorman, officials originally elective, but tending, as time gocs forward, to become hereditary. ${ }^{1}$

The most important change to be noticed, as the German invaders make their new homes, is that the Appearance King appears. In some tribes of the Teuof kingship. tons there had been in the earliest historic day a shadowy functionary, in a certain sense an over-lord through the suffrages of the freemen. The conquerors of Britain were not among these tribes, the folk-moot being supreme. Still, in carrying on war, the army-chiefs, heretogas, elected from among the æthelings by the people, each surrounded by a personal retinue of warlike youths attracted by his prowess, headed the military expeditions. As the necessity for one-man power became pressing in order to make effective the extraordinary undertakings upon which the barbarians at length entered, more and more authority was given to that heretoga who showed himself valiant and wise, until in chieftains like Hengist, Horsa, Ella, and Cerdic, personages stepped forth among them in a character quite new. Like the old heretogas, they possessed no authority

1 In the constitutional sketch, Stubbs at present is mainly followed, with side-lights, however, from a number of other authorities. 
but such as was aceorded them by their fellow-tribesmen, though when onee constituted they had a power co-ordinate with that of the folk-moot. They were ehosen usually from families whose blood was thought purest. Their sway now, however, prevailed in times of peace as well as war; or rather, sinee in the subjugation of the great island war never died out, though it might have intervals of slumber, their authority became constant. The principle of heredity began to have more distinct recognition. The Cyningas, Kings, soon elaim descent from Odin, barbarous people turning readily to the mythical. The qualities which made a great leader conspicuous would be likely to be found in his line. Some kinsman, therefore, by no means necessarily the son, - for heirs weak and wicked were for centuries passed over, - would be chosen to suceeed when the great lealer had played his part. The comitatus, too, acquires in the conquest greater definiteness, com- orgin of the posed of youths desiring education in arms, thegns. unpaid, but aeepting entertaimment and gifts of horses and weapons. From these proceeds the class of thegne, - as regards the King, servants and retainers; as regards the people, an upper class supplanting the ancient athelings,-- and from the thegns, as will be presently seen, a memorable development will one day flow.

In the almost speechless past in which the AngloSaxon eonquest is involvel, the lispings of history beeame at last audible. Pope Gregrory at Rome, lieholding in the slave market. among the aptives from foreign lands, the blomele Angles, finds it possible to beatify them ly so simples a process as the insertions 
of a letter. ${ }^{1}$ Augustine accomplishes his great conConversion of version. The seething discord of the earthe Anglo-
Saxons to Christianity. and in the Heptarchy at last, the vigor of Egbert achievès the supremacy of Wessex. Up to this time, the beginning of the ninth century, the church, the two archbishops of Canterbury and York at the head, has been the only unity among the distraeted English; for so we may now eall them. With the rise of Wessex comes about a political unity. Throughout these confused centuries no great change in institutions takes place, though names are trans ferred, and a general consolidation can be noticed. What in the seventh eentury was a state becomes, in the tenth, a shire, while the shire of the seventh century drops in the tenth into the position of the hundred. The King, partly elective and partly hereditary, is at the top; below him the land-owning freemen, in whose tun-scipes the tie of neighborhood seems entirely to have replaced the earlier tie of kinship. The tun-moots are primary assemblies, the moots of hundred and shire to a considerable extent representative. A nation has come into existence, far larger, both as regards territory and numbers, than the Teuton invaders have before known. Since a gathering of freemen into a great folk-moot has become The witenage. no longer possible, in its place is found mote. the witenagemote, meeting of the wise, the witan consisting of the King's wife and sons, the bishops, the ealdormen of the shires, and a number of the King's friends and dependents. No formal denial of the right to be present is ever made as

1 "Non Angli, sed angeli." 
regards the masses of the ceorls, but it comes about that only the rich and powerful usually appear. ${ }^{1}$ The witenagemote inherits much of the power of the folk-moot, choosing for example the King. Following the principle of hereditary succession, which is never set aside except in extraordinary emergencies, the kingship is restricted to one family, the best qualified person who stands in close relationship to the last King being chosen. For ages to come, however, the acknowledgment or recognition by a crowd of plain men gathered about the coronation chair, expressed in some tumultuous way, is never omitted - a more or less informal but quite essential supplement to the action of the witan.

In America, to-day, the President onee chosen, and the Upper House with the long term of its members, form a much-valued eounterpoise to the action of the popular will in the eyes of observers who may be regarded as impartial. ${ }^{2}$ So, probably, in the later Anglo-Saxon constitution, the King and the witan formed often a salutary counterpoise to the democracy. Radical changes from the ancient ways do not appear, though new applieations of old forms and methods are not rare. If grave innovations are threatened, some conservative ruler is sure to Work of restore things as nearly as possible to the Alred. ancient course. This was notalbly, the case with Alfred, at the end of the ninth contury, whose greatness more than anglit alse consisted in this, that he knew the value of the free institutions of his comntry.

1 Freeman : (irowth of the English Constitution, p. (in, etc.

2 Sir H. Maine: Popmlar (iovermment, article on the Amerien Constitution. Bryce: Ameriean Commonwealth, I. 
He sought not to make new laws of his own devising, "when it was unknown to him what of them would be liked by those who should come after him," but gave all his efforts toward the re-invigoration, so far as circumstances permitted, of the primitive institutions. $^{1}$

It cost a fierce struggle to maintain this polity against enemies within, a still fiercer struggle to maintain it against enemies without. From a station in the west of England once, as the train paused for a moment, I looked across a league or more of country, to where a hill sloped steeply up from the plain. Standing out against the deep green turf could be seen in clear outline the white figure of a horse, each detail remarkably perfect from the distance at which it was beheld. A thousand years or more had passed since the surface soil had been scraped away, allowing the chalk substratum to appear through in the gigantic delineation; for it is said to have been done by the hands of Alfred's Saxons, victorious close by over an army of Danes. But the Danes were not always vanquished, and at last succeeded in seating upon the English throne princes of their own stock. Closely allied with the Saxons though they were in blood, tongue, and institutions, attachment to the ancient order seems to have been less deeply stamped Influence of in their grain; and under their domination the Danes. may be observed the threatening progress of an innovation which was destined before long to supersede utterly, to all appearance, Anglo-Saxon freedom. Each heretoga had had, from the earliest times, as we have seen, his gesith, or comitatus, the

1 Taswell-Langmead: English Constitutional History, p. 43. 
company of warlike youths who followed his banner, devoting to him their labor and valor, while they received in return from him entertainment and protection. In the time of the Danes it became clear that the gesith was the germ of a growth so portentous as the feudal system. In the wars, at this time especially sharp, the ceorls were forced to "commend "themselves in great numbers to thegns, receiving protection in return for service, now with the ploughshare, now with the spear, in the fitful alternation of peace with strife. Thus the ceorls sank from the condition of pure freemen and beeame bound to soil and lord. The change by no means involved an entire destruetion of their old rights : they retained their land free as against all men but their lords, and continued to regulate their own affairs as before in the moots of tun, hundred, and shire. ${ }^{1}$ There was a liability, however, as never before, to interference, a liability that inereased; for the hour of Incipient feufendalism was at hand. In the time of dalism.

Edward the Confessor the air was full of ehange. The popular elements of the polity were becoming more and more depressed; the great thegns, dependents of the Sovereign, pushed aside or quite superserled the ancient atheling; the witenagemote beame more and more a royal eouncil, to which gathered only the great officers of the realm. Nevertheless, a remnant of the old order remaincel. When the witm hat elected the king, it was not felt that the action was confirmed until the ring of citizens at Westminstrer or Winchester had shouted their arknowled rment ahout the enronation ehair. At Eslwarl's drath, the nation

1 Green: Short History of the Englisls Prople, p. 24. 
exercised its sovereign right to choose a ruler to its mind, passing by the next of kin as inefficient, going even beyond the royal line, to place the crown on the brow of Harold. More than all, quite beneath the surface, as it were, each village-moot disenssed and voted, and from each went forth the representatives to speak for their townsmen in the larger sphere. In dark centuries that were to come, men often reealled with fondness the laws of Edward the Confessor, and demanded their restoration. We reach now an event so important in the history of Anglo-Saxon freedom that it will be in place to give it careful consideration. 


\section{CHAPTER III.}

\section{THE BATTLE OF HASTINGS.}

1066.

There is a little patch of a square mile or so, in the midst of the rich Sussex landseape in England. Through it, in low ground, sluggishly flows a small brook, and from the brook pearance of ridges slope up gently on either hand. It Senlac.

is covered for the most part with the green, thick English grass, dotted now and then by old elms and oaks. A gray, half-ruined wall, toothed with battlements at the summit, runs along one verge of the field; and there are two or three old towers, forlorn, through desertion and decrepitude, as Lears, whose comforting Cordelias are masses of elose-elinging ivy, - wall aud towers suggesting a splendor that has now departerl. What happened there in Oetoles, 1066, decided some important things; for instanee, that in the sentence that is now being written there shomld be nineteen words of Saxon origrin and four of Latin; and that in general, when we write and talk, about a yuarter of our speech shombl be derived from liome, and three-quarters from the German forests. It was derided there, in fatet, that those of us of Emglish book are what we are in mind and bonly, - a cross, namcly, between two tough stocks, each of which 
contributed precious qualities of brain and brawn to form a race which in the nineteenth century should stand so high. The field is that of Hastings, where the Normans under William beat the Saxons under Harold. Thence came a blending of tongues; thence a blending of traits - on the one hand enterprise, on the other sturdy fortitude - into a national character, too full of spring to break, too hard to be wasted, as carbon and iron blend together into steel.

One day, at the end of September, I stood on the beach at Hastings, a watering-place of some fashion The beach at on the south coast of England. It was Hastings.

a slope covered with rough shingle, close upon one edge of which crowded the blocks of the modern town, and on the other, the waters of the English Chamnel. On the summit of a high eliff to the eastward was the ruin of a Norman castle - cliff and ruin so in sympathy through a long community of stormy exposure, that the turf and rock of the downs seemed to rise into the moss and masonry with scarcely a perceptible dividing line. In front lay in the motionless air the wide glassy level of the Channel, with the horizon line blotted out by the afternoon haze. Coasters lay at anchor off the beach, somewhat dim, with their sails hanging slack. There was a sound of oars from pleasure-boats, and as I stood on the beach, the sailors came up and pressed me to row with them. Close by, among the many promenaders, a Sunday-school from an interior village was holding a picnic. A day or two before, - it was in 1870 , the Prince Imperial from France, with the Empress, just driven from Paris, had landed in Hastings from Normandy in great distress. Mother and son were 
still in the town, and not improbably among the groups on the beach.

It was in a different way that a prince from France landed at the same spot eight hundred years ago. Had I stood then on the shore looking southward through precisely such Septem- $\begin{aligned} & \text { Landing of } \\ & \text { the } \\ & \text { in } 106 \text { ormans }\end{aligned}$ ber mist upon a motionless sea, I should have seen countless sails floating up in the offing; and, in the front of the fleet, an ornamented bark, with a great cross on its flag, a sail marked with a coat of arms of three lions, and on the prow a brazen child holding an arrow and a bow bent to shoot. The chronicler, William of Malmesbury, says the sails of the vessel were crimson. These were kept turned to the wind and aided by oars until finally the keel grated upon the shore; and the multitude of craft that followed, bringing sixty thousand men, ranging eastward and westward for miles on either hand, were beached one after another by their erews in a similar manner. Over their sides instantly sprang a multitude of arehers; then of linights; then from the holds of the ships were led the horses, full of mettle from their long eonfinement, which panced on the sand and filled the air with their neighing. Lastly, on the ship whose prow bore the brazen ehild, a tall, strong man approached the of prparance Wil. side. His hair and beard were light, his faee florid. It had power and decision, bespealing a character fearless, enterprising, cruel. As he lapred down in his armor from the low vessel upon the wet samd, his foot slipped, and he fell forward upon his two hands. The thousands watehing him from the decks of the vessels and from the beach sent up at 
once a cry of distress; for it was taken as a sign of evil omen. Several of the chroniclers say it was a knight standing by who gave a favorable turn to the incident by a sudden explanation; but I like best the account of Wace, in the fine old "Roman de Rou," whose father was a soldier in that host, and had, no doubt, told the whole story to the son. It is that the strong warrior sprang up vigorously, and holding on high his dripping hands full of wet sand: "See, my lords," he cried, "by the splendor of God, I have taken possession of England with both my hands. It is now mine, and what is mine is yours." It was Duke William of Normandy. How he and his followers looked, with their kite-shaped shields, their helmets with the "nasals" projecting down from the front, their chain-armor, their boots of steel or strips of variegated cloth wound about the leg from knee to ankle, - all this we know from the Bayeux tapestry. What they said and did was rehearsed at length by many a patient monk, and far more picturesquely by the minstrels, who told the tale to the sound of the harp many generations after, to King and Difficult situ- noble. The Saxon King, Harold, was Difficult situ-
old.

north a rival claimant; but it was at that very time that the crimson sail came leading the Norman fleet from the southward, when the Saxons, though victorious, were weakened and disorganized. Harold, however, hurried to meet the new encmy, leaving behind, in his impetuosity, all the strength of the northern counties. He made a hasty levy of forces in London and in the south, and came swiftly towards the coast, hoping to take William by surprise. 
Finding the hope vain, he drew up his army a few miles from the shore and waited for the Norman onset.

Turning from the ealm sea and the beach which those historic keels had grated, I followed baek on William's track to the scene of the engagement. I rode through farms and handsome estates where there was nothing to suggest what filled my own thoughts but the name of the station at which I finally alighted, - Battle. Thence I walked into the High Street of the little town, whose existence dates back even to the great day, when it was called Senlac. Each reeeding century had left its wave-mark on the little ridge where ran the principal street. The railroad depot was a wrinkle which to-day had made, and going from thence there were waifs deposited now by one time and now by another. There was a portieo on which beaux of George the Fourth's time might have stood in surtouts and high stocks; old thatehed roofs, with house-leek green among the weather-beaten mass, that eame from a hundred years back; projecting upper stories from Cromwell's day. Close to the chureh I got glimpses of a lovely vicarage, withdrawn into quiet, whose shoulow-lappled front had the elaborate gables and oriel windows above and below that marked it as klizalethan, and the chureh itself wats partly at least, from the Wans of the Roses. l3ut at the end of the strect rose a strueture so massive and venerable that it subordinated to itself the whole of the little villacere. It was two-storied, guarded at the mattedubey. ends by solid turrets, and lattlemented at the top. In the eentre was a broal, low-arched gate, alove which 
the front rose sixty feet into a huge square tower. The side of the gateway was sculptured with the heads of Norman kings and queens. Everywhere over the front the weather had eaten into the brown stone, so that it was marked and crow's-footed as an old man's face. There was no decrepitude, however, but the halest old age. I went up to a narrow open door close by the broader portal. I found the masonry was many feet in thickness, and the doorstep firm and serviceable, though deeply grooved by foot-beats. From the dim room beyond, lit by slits in the thick wall, a woman came forward to answer my inquiries. It was the gateway of famous Battle Abbey, built by William to conmemorate the victory on the spot where he won it. Following the direction, I turned out of the High Street into a footpath, skirted the enclosure of a park, with a ravine to the right which once was full of wounded Saxons, and came out at last upon more open ground - a ridge of greensward, with now and then a tree, the ground from which descended to a little brook, then rose again into an answering ridge. The whole was traversed here and there by hedges, there were stacks about farmhouses; sometimes the brown thatch of cottages; to the left, the irregular line of the ruined abbey, with the fresher buildings of a nobleman's seat - all sweet under the subdued light of the autumn afternoon. I stood on the spot occupied by Harold's vanguard, the men of Kent.

I counsel all who make a pilgrimage to Hastings to take as a guide for the battle-field the old "Roman

The Roman de Rou. de Rou," either the translation, or, still better, the original Norman-French, as 
Thierry gives it in an appendix. ${ }^{1}$ A little previous study will make it intelligible enough to a reader of ordinary French; and if it is crossed now and then by an obscurity, the fine ehivalric picture is hardly injured. It is like the fierce beauty of a knight's face suggesting itself through helmet-bars; and the prompt iambics of the metre strike the ear with a vigorous music, like the rhythmic hoof-beat of a troop ranging for a charge. I could easily trace from point to point the progress of the battle. Right from my position had the handsome King, the idol of his people, run his simple entrenchment, - a line of stakes between which osiers were twisted. This marked the front of the position; and about the knoll to the left, a stronger and higher enclosure of the same sort seems to have been made for the protection of the Saxon standard, - the figure of a fighting man embroidered upon a banner and richly set with The two ar. gems and gold. 'The Norman monk, Or- mies opposed. derieus Vitalis, while condemning Harold as cruel and perjured, shows him in at tractive colors. He had a fine mind and ready eloquence, was intrep id and courteous, stalwart in figure, and of great strengtl. IIe appears in the Bayeux tapestry in a tunic of iron rings, and probably on the battle dity wore his crown upon his helmet, as was the enstom of Kings of his race. 'The banner shone and sparkled above a-strong, yellowhaired host, among whose weapons the two-handed axe was conspicuons. Their shichls were romol, with a boss in the eentre. Probally, sinee the levies (ame in hastily at the King's call, some wore the

\footnotetext{
1 Creasy gives much of it in the "Fifteen l)ecisive battles of the world."
} 
ancient picturesque Saxon armor, described by Sir Samuel Meyrick, ${ }^{1}$ heirlooms from warriors who had fought against the Danes, - plates of tough, hard leather overlying one another on a long-skirted tunic, leaf-shaped and stained variously, brown, orange, or scarlet, so that the men must have seemed to have clothed themselves from the October woods that were gorgeous about them. Raising my eyes and glancing across to the opposite slope, I tried to call up a vision of the Norman columns, troops of horsemen in steel, with front and flanks guarded by archers and pikemen in quilted coats or girt about with hides. I thought I could nearly fix the spot where the duke, putting on his hauberk, threw it over his shoulder, the back side in front. Those who stood near were sorely alarmed at the bad omen, as at the landing; but the ready leader changed it in an instant, crying out: "The hauberk which was turned wrong by me and then set right signifies that a change will take place out of the matter which is now stirring. We shall see the name of duke changed to King." The duke then mounted his Spanish charger and careered before his retinue, who burst forth into impetuous tribute to his strength and prowess.

Down the slope there, at nine o'clock, moved the Norman lines. But the page of battle about to be written in blood was illuminated at its edge with picThe minstrel turesque poetry. The minstrel Taillefer, Taillefer. having begged the boon of William, suddenly spurred forward to within a few paces of the waiting Saxons, pausing, I conjectured, a few rods down the slope from where I sat. There he sang the

1 Antient Armour, I, p. liiii, introduction. 
song of Roland and the peers of Charlemagne, engaging meantime in single combats, until at length he fell under a lance-thrust. Says the "Roman de Rou":-

"Taillefer, ki mult bien cantout,

Sor un eheval ki tost alout,

Devant li dus alont cantant

De Karlemaine e de Rollant,

E d'Oliver e des vassals

Ki morurent en Renchevals.

Sires, dist 'Taillefer, mierei,

Jo vos ai lungement servi ;

Otreiz mei, ke jo n'i faille,

$\mathrm{Li}$ primier colp de la bataille."

The battle now began with the utmost fierceness. Over the slopes the trumpets rang, the tramp of the horses resounded hollow on the eartl, the shields echoed, struck by sworks and maces. Like swarms of migrating wild fowl, the feathered arrows of the arehers sounded throngh the air, which they darkened by their number. The Normans shonted their war-ery, "God aid us!" 'The Saxons clamored in return, "Out, ont, IIoly Cross: God Almighty!" 'The "Roman de Rou" is here most pleasantly quaint:-

\author{
"Olicrosse, 'sovent erinent ; \\ E'Godemite, 'reclamoent; \\ 'Olicrosse, 'est en enyleiz \\ Ke Sainte Croix est 'n franceiz, \\ E'Codemite, 'iltritant \\ Com en franceiz Dex tot poissant."
}


The wicker-work, which with modern arms would be so feeble a barrier, was to the Normans a most formidable obstacle. From nine o'clock until Dangerous
Bituation of the Normans.

noon there was no advantage on either side. Then, however, a troop of Bretons under Eustace, Count of Boulogne, which had been specially engaged, fell back before the Saxons in almost utter rout. In the low ground, his followers became involved in ditches and in the brook, and perished by the hundred. Utter defeat seemed to lie before the invaders. Bishop Odo of Bayeux, William's brother, with a white ecclesiastical dress sweeping about his stately figure, but wearing a hauberk as well and with a mace swinging at his wrist, dashed on a white horse into the confusion, crying, "Stand fast!" William, too, who had been supposed to be slain, flung his helmet from him, and with head bare, stopped the flight. "I am here!" he cried. "Look at me; I live, and will conquer!" Throughout the afternoon the clang of the conflict was unabated. Somewhere toward four o'clock, it is probable, took place the event which was the beginning of the end. William, observing that the shafts of the archers, shot horizontally, stuck in the osiers and did little harm, ordered that they should be shot upward, that they might descend vertically upon the heads of the Saxons. Aloft flew Harold the arrows. Harold, looking up unwarily, wounded. received one in his left eye. Blinded, and crazed with pain, he drew it out, and leaned exhausted upon his shield. Just here the Normans practised a stratagem with results to them most fortunate. Their horsemen feigned a retreat in great confusion into the low ground, leaving their archers behind them. 
The Saxons, unrestrained now that Harold was wounded, rushed down the hill in disorderly pursuit, - "like sand without lime," is the graphic phrase of Matthew of Westminster. At a signal from William, the knights returned on the gallop and swept round them; then, fighting backward, Norman and Saxon entered the entrenchment together.

The elosing scenes are made sadly vivid in the old tales. The men of Kent who survived, and the levies of Essex and Sussex collected with the The rout of bleeding Harold at the foot of the gleam- the Saxons. ing standard. Covered with sweat and blood, they shouted cries of defiance that the Normans compared to the barking of dogs. But the knights came charging, William at the head fighting like a common manat-arms. The sun had sunk below the level of the woods. Twenty Norman knights, devoting themselves to death or victory, made their way to the standard's foot. The blinded King struck wildly at his foes; but a blow on the helmet felled him, and the sword of a knight cut his thigh through to the bone. In the twilight the last resistance was beaten down, and a group of exhausted men stood with uncertain footing upon the heap of corpses. The standard of the dead Harold fell, and that of William took its place.

"Then the duke took off his-armor, and the Barons and knights came, when he had unstrung his shield, and took the helmet from his head and the hauberk from his back, and sat the heary blows upon his shield and how his helmet was dinterl in, and all greatly womlered, and sairl: "Such a Baron never bestrode war-horse, nor dealt such blows, nor 
did such feats of arms; neither has there been on earth such a knight since Roland and Oliver.' And the duke stood meanwhile among them, of noble stature and mien, and rendered thanks to the King of Glory through whom he had the victory, and he ate and drank among the dead, and slept that night upon the field."

William was fierce as the lions which he had chosen for his escutcheon; but there is a superb strength in the historic figure. He had begun to take on some superficial refinement and accomplishment, just as upon the steel of his armor were embossed some few lines of ornament - a fine type of the Norse barbarian, whose tumultuous forces were beginning to be steadied and calmed for the ruling of the world. No doubt he was a sad scourge to his new domain; and yet it is not slight praise which our infant history accords him, pleasantly lisping in the Anglo-Saxon chronicle: "Man mihte faran ofer his rice mid his bosme fullum goldes ungedered" ("One might go through his kingdom full of gold unharmed"); and a passing flush of genial poetry burns momentarily in the dry, meagre record in the passage: "He loved the tall deer as if he were their father."

This is the story whose outline I read on the ridge, sitting where waited the Kentish vanguard for the Norman charge. I went slowly down the A walk to-day
over the battle-field.

troops to the spot where they were massacred. Centuries after, in wet weather, the brook was believed to flow with a reddish tinge, remembering the ancient slaughter. As I saw it, its bed was nearly dry, and in it grew osiers, descendants, 
perhaps, of slips that were woven into Harold's entrenehment, as I pleased myself with fancying I might be a descendant of a tattooed eeorl of Kent that stood sheltered behind them. It must have been just here that Odo, the bishop, rode forward with his mace; and here that the Spanish eharger pranced in the morning, and the eager Barons burst out rapturously over their leader's beauty and manhood. The gray ruin of the abbey now lay opposite; among constructions of a more recent date, a broken wall, an iry-covered turret, a mouldering gable pierced here and there with the rounded Norman areh. It was just there, where within the wall a remnant of the high altar yet remains, that the gems and gold of the Saxon standard flashed over the combat. That night there was seareely a soul in sight. Lovely upon the trees, here and there yellow and searlet, where the autumn was even then kindling, was the sunlight through the haze. The quiet fields sloped smoothly to the brook, welted down to the hillsides by the long herlges, and loossy with oaks and elms. The old brattle-field was indeed at peace. Ridling back to london in the dusk, I found myself imagining that the romoling of the hills, the wide moor, the patehes of woodland, might be somewhat as they were when ont from all this comntry the faithful levies came gathering to Harold's side. Old oaks were in the fields, which possibly mayeven then bave been standing: or whose parent acorns, at least, dropper from branches heneath whose shade as the King rushed too hotly sonthwarl, tired footmen might have fallen out to rest their blistered feet. 


\section{CHAPTER IV.}

\section{MAGNA CHARTA AND THE RISE OF PARLIAMENT.}

William I, 1066. William II, 10s7.

Henry I, 1100.
Stephen, 1135.

Henry II, 1154.

Richard I, 1189.
John, 1199.

Henry 1II, 1216.

Ed ward I, 1272.

THE ancient popular government underwent a great submergence through the Normans. These invaders,

Submergence of popular government through feu. dallem.

originally Scandinavian rovers, and probably then scarcely, if at all, distinguishable from the Danes, so long the scourge of England, had been in contact with the Franks, a German tribe, which after having conquered the Romanized Gauls, had undergone through the vanquished very considerable modification, blending with them into one people, assuming their language and many of their institutions. The Franks, in their turn, had wrought with a curious power, during a century and a half, upon the followers of Rolf the Ganger, the successful freebooter to whom had been ceded Northwestern France, until in 1066 William and his followers had accepted the tongue and customs of those who had been subdued. The Frankish polity, adopted by the Normans, had early shown, even before the emigrations from Germany, a difference from that of the Saxons. In the former the authority of the King was at first a well-marked feature, for which, in the case of the latter, must be 
supplied, as we liave seen, the rule of the elected heretogas, or of the folk-moot; but as time proceeds, the authority of the King among the Franks diminishes. Feudalism (plain signs of which, developed from the ancient institution of the comitatus, are traceable in Saxon England, particularly under the rule of the Danish Kings), had received among the Franks a much more thorough development. 'The great vassals almost equalled the King.

The Roman custom of granting lands to be held by tenure of military service, combined with the Teutonic comitatus to produce Frankish fendalism. But feudalism never prevailed in England to the extent that it did upon the continent; the Kings managed, except for one reign, to keep great power in their own hands, and were not overawed by vassals.

Although causing such woe to the vanquished, and overlying so thoroughly for the time being AngloSaxon freedom, the effect of the Norman ritimate good conquest, viewed in the historic perspec- effict of Nortive, was only good. It ereated in Eng- quest. land a sense of unity which before had been lacking. By mingling their strin with that of the English, the Normans adderl fire and vigor to the stock. So far as they remaned distinctly Norman, they provoked and stimulated the energies of the vanquished, even by their opposition and oppression. Before leaving Normanly, William had ruled his people as a personal sovereign, with the Charncter of advice and eonsent of a comncil of great Barons who stood to him in a fendal relation. The mass of the people were cultivators, living in strict dependence upon the lorks, to whose standiurls they 
might at any moment be rallied, either for defence or the foray, now and then remembering something of the ancient Teutonic freedom, but with nothing at all corresponding to the vigorous folk moot, the selfgovernment which the Anglo-Saxons had maintained. The vassal must serve the lord; the lord must protect and also judge the vassal.

To an observer studying the period superficially, it would seem that popular freedom gives no trace of itself for one hundred and fifty years, until in the exaction of Magna Charta took place a memorable outburst of the ancient spirit. That, however, was by no means unprepared, and we have now briefly to trace the indications of a free life that persisted uncrushed beneath the superincumbent mass that had overwhelmed it. 'To all appearance, indeed, nothing could be more arbitrary than William's rule. He became the supreme landlord of the kingdom. All the common land of the nation became his absolutely; and all land which had been appropriated, it was necessary now to hold from him mediately, if not immediately, for between him and the mass of the people, rank stood beneath rank in the feudal subordination. In place of the countless free-holders of the former time came fifteen hundred tenants-in-chief, on the one hand owning the suzerainty of the King, on the other hand exacting from liege-men, grade Domesday below grade, tribute and homage. In a Book. quiet room in Fetter Lane in London, in the Public Record Office, where are preserved the archives of England, one may see to-day the famous Domesday Book, in which the clerks of William made the record of the great survey and division by 
which this vast re-appropriation of England was accomplished. The attendant takes it for you out of its case of silver and glass, a massive volume, the inscription upon whose parehment leaves is as handsome and vivid as when the eyes of the Conqueror passed down the lines, to see that all was in order. As you behold it, an awe strikes you; for it is the very foundation of England, in one sense, upon which your eyes are fastened. Thousands of the eonquered, dispossessed, fled northward to the Seottish lowlands; thousands more, once free ceorls, sank to the eondition of villeins and serfs; while the remmant that suffered less, were still in every way humiliated, in the grasp of the rapacious and insolent horde who had fought with William at Senlac.

Nevertheless, a eareful eye to-day will see that William distubed as little as he eould the ancient eustoms. At his coronation, he scrupulously olserved the ancient Saxon usage. He was elected at Westminster by the witan, and aceepted afterward by the concourse of people, - the form which hat come to stand in place of the national recongnition. The mosts of shire, hmulred, and tun re- Persinecener of tatined something of their former power. tutionn in tun, In a dim way the oppresised people felt that the king wats a well-wislere to them, at any rate as compared with his lorks, the hated masters with whom they were immerliately in continet; and the King conld rely on the bulk of the people in all struggles with the great vassials, in spite of foulat obligritions to the immerliate suredains. 'The AnghoSixon system hath beren strongest in the colnesion of its lower organism, the atsisociation of individuals in 
the township, wapentake, and shire; the Norman system was strongest in the higher ranges, in the close relation of the sovereign to the tenants-in-chief. When the latter system was superimposed upon the former, the best elements of both were brought together, the weaker in each case disappearing. The dumb life of the Norman masses was superseded by the vigorous local self-government of the popular moots, with their constant, tumultuous, characterforming discussion. On the other hand, the somewhat shadowy Saxon King, doubtfully more powerful than his great earls, gave way to the Norman monarch, supreme above the strongest baron, who owed him definite allegiance. ${ }^{1}$

William Rufus, Henry I, and Stephen, the two sons and grandson of the Conqueror, constitute, with the great leader of the line, the Norman Character of
the King's title.

by no means the jus divinum, the divine right. If the Kings could have succeeded by the law of inheritance solely, liberty would, no doubt, have perished; but the election at the coronation in the case of each was carefully observed. It appeared, perhaps, to be a mere perfunctory ceremony, but it had by no means lost all of its earlier real importance. With the election, took place the formal acceptance by a crowd gathered from the neighborhood, who stood for the people. The oath to govern well was taken, and a solemn promise made to observe ancient ways. It all formed an important acknowledgment of the rights of the nation and a recognition of the duties of the sovereign. The power to elect and

1 Stubbs: Constitutional History, I, p. 278. 
approve implied at the same time a power to depose; and the fact that there were in every case others who, by blood, were as near the throne as the actual occupant, kept this power always in mind. The right of inheritance was held to be co-ordinate with election; the witenagemote remained substantially as before the conquest; no trace existed there of a representation of the free-holders in general; but though not yet traceable in the central council, representation was familiar enough in the lower courts.

In thoroughly developed feudalism, the ling, though at the top of the structure, is searcely more powerful than his great vassals. Against this danger both sons of the Conqueror of feudalism were forced to struggle, finding means to in England. resist in the help of the people, which help, the Kings, in the midst of their oppressions, were foreed to pay back by acts of grace. William Rufus testified to the nation that he had duties and they had rights. Henry I promised peace and good coinage, and restored the working of the lower moots as in the days of the Confessor. In the time of Stephen, feudiatism had its way. Inis great liegemen, entrenched in their eastles with which all England began to bristle, contested the authority of the suzerain, while they ground the people kelow them into the dust. The misery of the land, though so eruel, was yet in the end beneficent; it was so intolerable that something better must come perforee. The great Ienry II. first of the Plantagenet Kings (115t-1189), disilnued the femital party, destroged their strong-

lienry II sup. pressen the great iassals. holds, banished the merenaries with whom the lords had eonfronted the sovereign, and showed an inten- 
tion of ruling by means of, if not under the control of, the national council. He brought it about that juries of twelve men of the hundred and four men of the township should present before the justice all persons accused of felony by popular report; thus the people were distinctly recognized, and an important training prepared through which they became fitted for work that was to come for them in better days that were approaching.

The Curia Regis, the King's Court, must by no means escape our notice. Through this was exerThe Curia cised the judicial power of the King. The Regis. justices, while at work in the provinces, sat in the shire-moot, in which, besides the local magnates, sat also the reeve and four men and the parish priest from each township, after the venerable custom. The Parliament, the upspringing of which we shall have presently to study, was, when it came, a combination of local representatives with the council of great men of the land. It was no short step toward that when the Curia Regis and the shire-moot came together. The shire-moot had undergone no change, but was held "as in King Edward's day, and not otherwise." 'Twice a year it assembled, the lords of the land and their stewards appearing on the one hand, and the representatives of hundreds and townships, on the other. The ancient tun-scipes, to be sure, were now called manors, and were held by lords infeoffed by feudal grant. Of these manors, there were 1422 in the ancient demesne of the crown. But their courts baron were the primitive moots, the units of the ancient Anglo-Saxon polity. Multitudes of the freeholders had been depressed into villeinage, their children inheriting the debased station. 
Different grades ean be made out obscurely among these dependents, - liberi homines, sokemen, cotarii, bordarii, and thrall; but the Norman lord was disposed to depress all into one elass, Berfdom. - that of serfs, bound to the soil, and under obligation to render service. Nevertheless, the primitive fundamental organization was not obliterated. Towns now were growing rich and important, and at this time preserved the traditions of 'Teutonic liberty more perfeetly than the shires; for the burgesses, in the case of the larger ones, had a moot answering to the shiremoot, and also a moot of the ward answering to that of the hundred or wapentake. In the ease of smaller boroughs scattered through the provinees, the constitution was that of the hundred rather than the township. The condition of the serf was not utterly without hope; for if he could but obtain admission into a merchant-guild or club, and remain for a year and a day unelaimed by his lord, he was free. The practice of trial by jury strengthened now Trial by jury. the impulse toward freedom. Stubbs derives it from the Franks, with, perhaps, some distant relationship to the Roman law. Though introduced at the conquest, it does not, until Ifenry II, become a settled institution. Ileneeforth, however, there laty upon every common man the liability to act an a jurlge, even in cases of life and death. To ro such service fell within each man's experiener, - perhals to do it many times. How salutary the discipline, even thomgh the wisest decision may not be always reached!

The ancient freedom, therefore, was by no means dead beneath its superincumbent burden, lut simply 
oppressed and hidden. It needs no long searching to find it in the days when feudalism was heaviest, and in the great thirteenth century, at the first opportunity it gives plain manifestation of itself. With the last Accession of year of the twelfth century we reach the John. important reign of John, which was ushered in by a circumstance full of good omen. At the coronation, the Archbishop of Canterbury, as if the neglect of duty and rapacity of Richard I had shown the need of a reassertion of the ancient safeguards, declared that the right to reign comes to no man by birth, but is conferred by election, which the nation makes after invoking the Holy Ghost. On the 4th of August, 1213, a national council took place at St. Albans, to assess damages done to the church, in which not merely bishops and barons were present, but each township on the royal demesne sent its representatives, the traditional reeve and four men. Here, for the first time, we have historical proof of the summoning of representatives in any shape to the national council. It was, without doubt, intended that they should appear merely as witnesses; but it was important. For the last two or three reigns the divided nation had been growing together. French and Anglo-Saxon were blending fast into one speech; conquerors and conquered were becoming mutually interfused with one another's blood; community of perils and interests was bringing about an interchange of sympathy. At last, with the loss of Normandy, the circumstance ceased to exercise an influence which till now had caused the conquering race to feel a divided patriotism. Like the conquered, they were to have no land henceforth but England, and 
high and low extended hands to one another as had not been done before. We reach at length the 15 th of June, 1215.

Whoever stands on the great round tower of Windsor Castle, has under his eyes one of the most interesting landseapes of the world. The fairest part of England is spread out under Runnymede. his feet, through which winds the Thames eastward to where, on the horizon's edge, the bank of cloud and smoke marks the site of London. Not a point of the view but causes a thrill throngh great associations. The old tower here marks the churehyard of StokePogis, where Gray wrote his Elegy. The group of buildings elose at hand are Eton sehool, where, for four liundred years, the privileged boys of England have taken their start as they grew up, so many of them, into great historie figures. The landmark yonder stands on a field onee bloody, where the Red and White Roses elashed. The ehapel at your feet holds the tombs of Tudors, of Stnarts, and of the house of Brunswiek. There is no spot, however, in the wide prospect, upon which the eyes of thoughtful men are likely to rest longer, than a patch of bright green grats, seen among the darker foliange of a forest, at the distance of a leagrle or so, - a spot which still bears the name of Rumnymede. IIere the tyrant John was fored to meet his Baronis and grant to them Magna ('harta. To extort it wats "the first ant of the mited nation, - the ('hureh, the Barons, and the Commons, for the first time thoromerhly at one. It is in form only the alet of the king ; in sulstance and historical position, it is the tirst rfort of at corlurrate life that has reated its foll andscionsmess, re- 
solved to act for itself, and able to carry out the resolution. The whole constitutional history of England is little more than a commentary on Magna Charta." I

The Great Charter ${ }^{2}$ contains a summing up of the rights and duties that had been growing into recogAnalysis of nition, while the nation was growing into MagnaCharta. consciousness. The Commons are joined with the Barons in the execution of the Charter, and now, for the first time since the overturn of the old order, take part in the great life of the nation. It is in the form of a royal grant, but is really a treaty, which John had no idea of keeping, between him and his subjects, based on a series of articles drawn up by them. The Barons maintain the right of the whole people as against themselves as well as against the King. The rights of common men are as carefully provided for as those of the nobles; for always when the privilege of the simple freeman is not secured by the provision which affects the high-born, an added clause defines and protects his right. The whole advantage is secured for the common man by the comprehensive article which closes the essential part of the Charter. The XIIth, XIIIth, XIVth, and $\mathrm{XVth}$ articles are those most interesting. No tax is to be exacted without a grant from the common council of the realm; and the sense of the nation, with regard to the tax, is to be taken in a duly summoned assembly. This claim was not at all new, but the right had never before been stated in form so clear, and the statement startled even the Barons. 
The struggle for it did not end here, the claim not being fully conceded and firmly established until the close of the century. The nobles, as regards those below them, are bound here in the same way as the King. The XXXIXth and XLth clauses are famous and precious enumciations of principles. In these the right to be tried by his peers is secured to every freeman. This, too, was no novelty; the very formula used is probably derived from certain ancient laws; but the declaration was important. It is no new freedom, therefore, now for the first time appearing, but simply a coming up into consciousness again of the ameient right, and a revival of the old determination to make the right good. ${ }^{1}$

It was probably through the clergy, the great Langton, Archbishop of Canterlury, in partieular, that the rights of the Commons - free- Langton's holders, merehants, even villeins - were work. so carefully regarded. These churehmen and their successors led and acted for the people until the Reformation, three lumdred years after this time, with little jealousy of their growing influence, and it was the extinction of the influence of these natural leaders of the people, which caused the nation to fall so completely into despotie hands after the Wars of the Roses. It was in the North of England that the ery for freedom was first heard; but it was taken mp at length by the lamonial party in gemeral, and the demands berane definite moder the land of Langton, who followed in his redaction medels of former times. In such fashion as they eomlth. the matsses of men, until now mute since the conguest in all but loral

1 The account of Magna Clarta is summarizol from Stubls. 
affairs, signified their acceptance, the Londoners, ever foremost, in especial making plain their assent. Johm yielded in the full intention of eluding his promises, with the comnivance of the Pope. He died in the midst of the struggle, and Langton and the Barons took early occasion to prove to his successor that the Great Charter was no dead letter. In 1218 a fresh promulgation of it was required of Henry III, as the price of a subsidy, the principle being thus established that a redress of grievances must precede a grant to the Crown. Though the vital provision that men should not be taxed without their consent was then omitted, there was no step backward; in the succeeding three hundred years Magna Charta, with the lacking clause restored, was confirmed more than thirty times. ${ }^{1}$

As one pauses in the British Museum at the case containing the autographs, looking through the glass, The copy of he sees within a few inches of his hand the Magna Charta Great Charter. Six hundred and seventyMuseum.

five years have yellowed and mouldered the parchment, which also has been shrivelled by fire. The Latin of the mediæval scribes is still, however, in part, legible, the famous XXXIXth and XLth articles standing out with especial distinctness, as if the very flames had held them in honor. There are the names of the Barons who, halting their battlesteeds under the trees of Windsor forest, strode in armor that day (how precarious were their lives!) across the turf of Runnymede. There at the bottom

1 Hannis Taylor: Origin and Growth of the English Constitution, I, p. 423. 
is the great seal affixed by the fiat of the evil King.1 Whoever makes real to himself the signifieance of that wrinkled sheet must feel in his heart a thrill of awe. Magna Charta in 1215, the Petition of Right of 1628 , the Bill of Rights of 1688 , the Declaration of Independence of 1776 , the Constitution of the United States of 1787, the Reform Bill of 1832, - how memorable the series! Each rests upon its predecessor from Magna Charta forward. How venerable the doeument that forms the base of such a series! and yet Magna Charta is but a small instalment of AngloSaxon freedom, - govermment of the people. by the people, and for the people, - which, snatehed away from our race, has been given back to us piecemeal, the proeess lasting through nearly a thousand years. A slight share in the publie govermment is thus, in the time of John, restored to the people. We are to trace the story until government of the people is fully given back.

Through Henry II the feudalism, so unrestricted in the years of Stephen, had been thoroughly curbed. The great feudatories having been beaten down, Richard and John felt very absolute, and the extortion of Magna Chartal, though, as has just been seen, it was simply a conservative expedient designed to maintain what had been, no doubt seemed to John a thoroughly revolutionary proceeding. When Magna Charta speaks of the national commoil, it recognizes none as entitled to membership therein but temantsin-chief. Only such were smumoned, and a roval smmmons had now beeome essential. The vatst num-

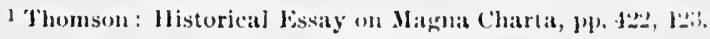


ber holding, of those subordinate to the King, were not counted as entitled to a voice. Moreover, there is rarely record of any opposition in the council to the King's will, - much less of any power of initiating measures of policy or reform. But the great year 1265 was at hand, the date of the second important crisis of this eventful century. The practice and obligation to do jury duty had been affording to the lowest freemen important discipline. The shire-moots went on as in Saxon times, made up of the landholders and their stewards, whom the sheriff, in his official coat, surrounded by liveried followers, presided over; while, on the outskirts of the crowd, in some undistinguished place, no doubt, but still a recognized and indispensable part of the assembly, the parish priest and the reeve and four men, in coarse brown smock-frocks of a fashion as ancient perhaps as the function the wearers were administering (and yet a costume still worn by the English ploughman), voted and spoke for each township on all local matters. The time had come when representation, which had lived on in the local self-government, was to play a larger part. "The humble processes by which men had made their by-laws in the manorial courts and fined offenders, by which they had assessed estates or presented the report of their neighbors, by which they had learned to work with the judges of the King's court for the determination of questions of custom, right, justice, and equity, were the training for the higher functions, in which they were to work out the right of taxation, legislation, and political determination on national action." 1

1 Stubbs: Constitutional History, I, p. 623. 
"The representative system," says Freeman, "is the great political invention of Teutonic Europe, the one form of political life to which neither Thucydides, Aristotle, nor Polybius ever $\begin{gathered}\text { Value of the } \\ \text { representative } \\ \text { system. }\end{gathered}$ saw more than the faintest approach." 1

"It is," says Dr. Franeis Lieber, "a flower of eivilization such as neither antiquity nor the middle ages either enjoyed or conceived of, - something direct and positive in itself, an institution having its own full, distinct, and independent eharacter, the exeellenee of which is not to be measured by asking how elosely it may approach to something beyond it, which would be the best thing, could we but have it, but which, for some reason, we must give up forever. The representative system seems to me one of the very greatest institutions that adorn the pages of the history of civilization; for through it alone can be obtained real eivil liberty, founded upon extensive politieal societies, and not on narrow city communities." 2

Let us obtain a elear idea of the eonditions under which this preeious thing must exist. It is only fitted to peoples among whom prevails a vigorons vigorous local self-govermment; for it is its success. not by instinct that men are able to form a proper judgment as to the qualifications or acts of their representatives. "Such judgment and the experience necessary to it ean never be got in any other way than by habitual and free discussion on similar elasses of subjects among those who feel that they have an immediate interest in the result. It is by the habit and experience of understanding and help-

1 History of Federalism, 11, p. 67.

2 Dr. Francis Lieber : l'olitical Ethies, 1I, p. 313. 
ing to manage their own affairs and the affairs of their own district, that men can alone have their minds so trained as to be able to judge of the mode in which their representatives in Parliament, or in the narrow local council, ought to, and do, manage the affairs of the nation, the shire, or the borough. It is by the independence of thought and conduct to be only acquired by the habit of being continually called upon to express an opinion on, and to take an active part in the management of the affairs of their own district, that men can alone ever be really fit to elect representatives, either to Parliament or the local council, or to form sound or respect-worthy opinions on the conduct of such representatives." For successful application, then, of the representative system, there must also be "regular, fixed, frequent, and accessible meetings together of the freemen themselves, at which all matters done by the representative bodies shall be laid before the folk, discussed, and approved or disapproved; and at which all matters of common interest to the respective associated communities shall be brought forward and fully canvassed: and having undergone this process, the public opinion thereupon shall be truly, peaceably, and healthily expressed." 1

The previous consideration has made plain the fact that in the century of the Renaissance, when England, rising from barbarism and acquiring solidarity as a nation, after long distraction, assumed at last a representative system of broad national import, there was in the land ample and adequate foundation for

$1 \mathrm{~J}$. Toulmin Smith: Local Self-Government and Civilization, p. 29, etc. 
it. There had existed for many ages, moots of shires, hundreds, and tithings, - a system of local self-government minutely ramified and wisely devised, so that there should be fixed, frequent, regular, and accessible meetings together of the folk in every part. The purpose was to have the means of getting justice nigh at hand, and also of understanding, diseussing, and determining upon all matters of common interest. Before the Conquest, the moots had maintained themselves from a prehistoric day in vigorous activity; this system, eapable of thorough resuseitation, still existed everywhere. The substructure for a representative system, indeed, was prepared as it has been prepared in no other raee before or since. Upon this, now, in the fulness of time, was to be reared suecessfully the very noblest of political edifiees. The era in which and the man througl whom the work was done deserve to be forever remembered.

Riding at leisure from Coventry in the early light of an August morning, before long I was making my way with some difficulty across a eonsider- simon de able brook, which, however men may eome Montort and and go, runs on forever through the rich ment. English midlands. 'That obstatele passed, I soon reached a gateway, passing which, I had before me one of the most veneralile of ruins. A mighty keep of red stone, whose walls were yards in thickness, rose half-huried beneath heary masses of ivy, from the swarl below. Alont it stood, in rarions stages of decay, walls of lighter construetion, the windows and doorways of which, surmounted by the sraceful, lowpointed areh, showed that they eame from the Turlor periorl. Mounds of broken ontline, over which the 
turf had spread itself, marked the site of towers and outworks which had undergone a demolition more complete. Broad meadows stretched away from the higher ground of the castle site, from which, as I lay on the grass with the imposing mass of the keep before me, came a sound most incongruous with the romantic reverie to which one in such a place would like to surrender himself, - the clatter of an American mowing-machine. It was Kenilworth Castle, - a ruin as beautiful and as rich in historic associations as any in England. The brook which crosses the path thither from the village is the one which once supplied water for the moat and for the broad lake, which, covering the lower ground about, was of old an important circumstance in the strength of the position. To the many visitors to Kenilworth, the associations of the spot uppermost in the mind are of Leicester and Amy Robsart, and the magnificent entertainment, described by Scott, of Queen Elizabeth. There is another name, however, of far greater import in the history of AngloSaxon freedom, which should be remembered there, - that of Simon de Montfort, the founder of the House of Commons, of whom Kenilworth Castle was the home.

He was the youngest son of the cruel crusader against the Albigenses, the precursors of Protestantism, who lived in Southern Firance. Foreigner and adventurer that he was, regarded by the aristocracy into which he pushed himself as an upstart, the antecedents were strange enough for the part he was destined to play, - that of a great English statesman and patriot. He had married Eleanor, sister of King Henry III, and by that union had come into a front 
rank among the Barons. It was a time of disorder and bloodshed. Little by little concessions were made to the rising spirit of freedom in the people. The Great Charter was again and again confirmed. At last, in 1264, when Simon de Montfort, at discord with the King, by his victory over the royal party at Lewes, had become arbiter of the kingdom, he summoned the famous Parliament in which for the first time the Commons of England were fairly represented, - one of the greatest landmarks in the history of our lace. It met on the 20 th of January, 1265, not a national Parliament, in the strict sense of the worl, which in consequence of the dissensions was a thing impossible, but an assembly of the supporters of the existing government. The elergy, in that century leaders of the people and friends of freedom, were there in force, to the number of one hundred and twenty. Of nobles, there were but twenty-three, five earls and eighteen Barons, for the peers stood generally for the King; but a noteworthy feature of the Parliament was the representation of shires, cities, and boroughs. Two "disereet Knights " were present for earh shire, two representatives from each eity and borough. There were informalities; " l but the custom of election wats so well established that it could not have been negleeted on this neeasion. He was greater as an opponent of tylumy than ats a deviser of liberties. The fetters imposed on royal antoeran'y, combrous and entangled ats they were, seem to have beren an intergal part of his poliey; the means he took for admitting the nation to self-rosermment wall very much the form of an occasional or party cxpedient, which a longer tenure of individual power might have 
led him either to develop or discard. The idea, however, of representative government had ripened in his hand; and, although the germ of the growth lay in the primitive institutions of the land, Simon has the merit of having been one of the first to see the uses and glories to which it would ultimately grow." 1

Earl Simon stands in his century as a man of honor, of steady purpose, and of high military and administrative ability. Church and people loved him enthusiastically. He was held to be a saintly figure, and extolled affectionately in hymns. ${ }^{2}$

At the battle of Evesham, where he was surprised one August day in 1265, by Prince Edward, while looking for succor from his castle of Kenilworth, he was completely overwhelmed and afterwards slain.

1 Stubbs : Constitutional History, II, p. 100.

2 Creighton gives the following specimen among others :-

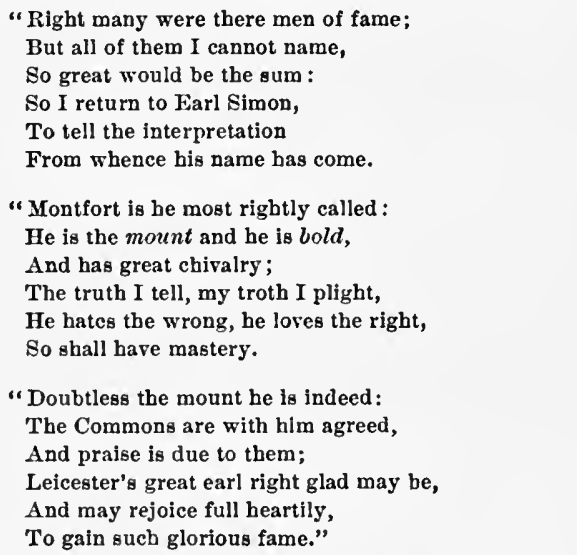

Translation: from Creighton's "Simon de Montfort," New York, 1877, p. 124. 
His body was cut to pieces and beeame the subject of miraculous stories. His hands were severed and given in charge to a messenger to be conveyed to a distant place. The messenger being present at a mass, when the lost was elevated, the hands of Earl Simon appeared from beneath their wrappings and put themselves together palm to palm in the attitude of prayer. So they were acenstomed to do in life, and in death the people believed the devont posture was not forgotten.

The third critical year of the thirteenth century is 1295. When Earl Simon beheld the host of Edward mancenving to compass his own destruction, on the field of Evesham, it is said Edward Iand that though he saw plainly the nearness of $\begin{gathered}\text { ment of the } \\ \text { Ilouse of } \\ \text { Commons. }\end{gathered}$ his own overthrow, he yet adnired the skill of the Prince, and proudly claimed that he himself had been the Prince's teacher. When Edward becime soon after one of the greatest of Kings, he showed that in peace as well as war he was a pmpil of the man whom he had slain. Thongh opposed to Earl Simon while the latter lived, yet he was constrained to pursue the poliey which hatd been entered upon, and he wrought to completion the strueture of the Parliament ats it stamb to-day. IIe wass al great lawgiver in a century of law-grivers; his contemporares were Frederick II in Ciemany and Italy, Lonis IX in France, and $A l_{p}$ honso the Wrise in Cistile. The constitution, as he left it at his death in 1307 , remains to this disy the morlel of representative institutions. IIe anticipated and almost superseded enstructive Iegislation for two centuries, furnishing at the sime time a basis which has served until the present hour. 
It was in the autumn of 1295 that he performed his most memorable act, the last formal step which established fully the representation of the Commons. The form of summons addressed to the prelates is most interesting, beginning with that quotation from the code of Justinian transmuted by Edward from a mere legal maxim into a great political and constitutional principle: "As the most righteous law, established by the provident cireumspection of the sacred princes, exhorts and ordains that that which touches all shall be approved by all, it is very evident that the common dangers must be met by measures concerted in eommon." 1 The writs issued to Barons and sheriffs, though more brief, are in similar strain. Each sheriff is to eause two knights of his shire, two eitizens of every city, and two burgesses of every borough, to be elected and returned, the representatives of the Commons to bring full power from their several constitueneies for doing what shall be ordained by common counsel. ${ }^{2}$

The reign of Edward was ushered in by a careful observance of the forms of election and acceptance, forms indeed never omitted, though sometimes they seemed mere idle ceremony. The times were full of tumult, - wars without and dissensions within. $\mathrm{He}$ was the ruthless King who flung the Jews out of England; the bards of Wales prayed that ruin might seize him, that confusion might wait upon his banners; - he won the victory of Falkirk, where so many Scots bled with Wallace. He was not, indeed, above being tempted to ambition, vindictiveness, and impatient

1 Taswell-Langmead : English Constitutional History, p. 245.

2 Stubbs : Constitutional History, II, p. 108, etc. 
violence. But the forward steps which the nation took, sometimes, to be sure, in spite of him, but sometimes under his guidance, were most momentous. The Great Charter was again and again confirmed, until it became as fixed as the hills, in the national life; the doctrine that grievanees must be redressed by those in power before supplies cam be granted was plainly admitted. In 1297, it was clearly established that there ean be no taxation without representation, - the principle upon which, five hundred years later, stood the Amerieans of '76, when they fought out their freedom: Parliament, too, stood forth, a welldefined and organized expositor of the national will. As one wanders among the graves of the great in Westminster Abbey, there is no tomb before which a more reverential pause may be made than the massive, unornamented sepulehre, built in a rude age, for the tall, stalwart monareh, the "Longshanks" of popular tradition, who bestrode to such purpose the realm to which he was born, - Edward I, strong in arm, brain, and soul. 


\section{CHAP'TER V.}

THE COMING UP OF THE SERFS.

Edward II, 1307. $\quad$ Edward III, 1327. $\quad$ Richard II, 1377.

IT was not only in England, in the thirteenth century, that national assemblies were coming into being. Condition of In Castile and Arragon, town representafreedoon in
Europe in the tives were appearing in the cortes. In 13th century. Sicily, Frederick II was instituting something very similar to the English shire-moots. In Germany, the cities appeared by deputies in the imperial diet. In France, the States-General were first summoned in 1302. These national councils were scarcely less proud and powerful than the one at Westminster. ${ }^{1}$ All, however, were destroyed or sank into insignificance. Only the English Parliament stood firmly on the constitutional right to give and withhold money, and maintained itself. In France and Spain, the outcome was royal absolutism. With the passing away of the Hohenstaufen, went Frederick II's institution in Italy. In Germany, there was utter disintegration, the life of the nation being diverted into hundreds of pretty provincial channels, while the people were smitten into dumbness. Meantime the Scandinavian kingdoms had scarcely emerged into the light of history, and in Russia pop-

1 Macaulay: History of England, I, p. 33. 
ular liberty underwent a curious hemming in, from which it has never recovered. In early times the moot in the mir or Slavic village was as distinctly marked and important as among the Saxons themselves. There was no development, however, of moots above, corresponding to those of the hundred and shire, and no use of the expedient of representation. The brilliant, ubiquitous Normans appeared to the east of the Baltic, as they did in France, England, Italy, and the Orient, assuming leadership here as everywhere, and imposing a feudalism which has endured until now. The popular life has persisted in the mir, but has never been able to rise into national significance.

In England, then, the ancient freedom revived, but in England alone. Can it be said that government of, by, and for the people had been thoroughly restored? By no means. The folk- Constitution oughly restored? By no means. The folk- of the early moot had possessed all the power once. It disappeared as regards central government, living on under the surface, as we have seen, in the various moots for local self-grovernment. 'The witenagemote, indeed, may have arisen from the national assembly, but it had become so changed in character, through the alsence of all but a few rich and powerful personages, that it must be regarded as a different thing. In the eourt of the Conqueror and his sons, the witenagemote had not disappeared: under Henry 11 , it became a complete feudal eouncil comsisting only of the King's tenants. At last, moler barl Simon and Edward, this grew into a full national asiembly ; the three estates, Clergy, Lords, and Commons. made it up, - the first and last by representation, the second 
directly, for each Lord had a seat by right. The great mark left by the thirteenth century on the constitution was the representation of the Commons. They are recognized in Magna Charta as creatures possessed of rights entitled to respect; under Earl Simon they were admitted to a voice in the government; under Edward, what Earl Simon had introduced was thoroughly established and systematized. The Parliament of 1295 is a precedent for all time to come. As regards form, the model of Edward has not been departed from in England, down to the present day, and is distinctly reflected, as will be hereafter seen, in the constitution of America. A quite different spirit, however, animates the ancient framework. In Edward's time, the voice in affairs which the people had gained was only faint. The monarch, though not autocratic, was immensely powerful; the privileged class of nobles, the clergy, too, possessed a might far outweighing that of the undistinguished mass. At present, in England, the plain people are nearly all-powerful; they are all-powerful in America and in the British dependencies. Many centuries were destined to pass before this thorough reinstatement of Anglo-Saxon freedom.

In the time of Edward I, one hundred and sixtysix cities and boroughs, and thirty-seven counties Importance of were represented in Parliament, and the Importance of
the knghhts-of. maximum number of representatives pres-
the-shire. the-shire. ent was four hundred and six. It was the knights-of-the-shire, seventy-four of them, two from each of the thirty-seven counties, who were at first the champions of the Commons. The divisions which had sent them to Westminster were coeval with the 
earliest Saxon occupation. The interests of these divisions were especially liable to injury at the hands of an arbitrary King, and it was natural that the knights-of-the-shire should be leaders in debate. It soon became evident that they were elected partly by the votes of the small free-holders of the counties, the yeomen, a class which gradually grows as the oppressions of feudalism relax (many The seomen. who had been ground down into some form of villeinage, rising into the character of independent cultivators), ${ }^{1}$ and becomes an immensely important constituent in the strength of the nation. From the younger sons of the yeomen were reeruited the archers and men-at-arms who made formidable the warfare of the Edwards and the Henrys. As tradesmen in cities, they rose often to be great merchants, and bound together in important ways town and country. In antiquity of possession of land and real purity of birth they were superior, usually, to those who despised them as ignoble, for their line went back far before the Conquest. As the midnle ages adrance, the recognition of their political rights beemes more and more distinct. There is, however, no proof that yeomen in the mirlde ages ever sat in P'arliament. There was no har to their election, and it may josiWy have happened, but the gentry pratically monopolized the representation. Represeutation was long regarded, not as a privilege, but as a burden: and quite possibly the absence of small free-loblers at Westminster was due to reluctance on their part, rather than to negleet of them by the eonstitueneies.

1 This movement was espercially marked during the lomg reign of llenry III, 1216-i2. J. Thorold Rogers: llistory of Agricullure and Prices, I, p. 3. 
As compared with the knights-of-the-shire, the borough members were insignificant in their influence.

Unfortunate state of the boroughs.
Though cities and towns had once played an important part in the conservation of freedom, it had come about that there were great irregularities in their constitutions. No uniform type of eity and borough court, corresponding to the shire-moot, existed. There were towns in which local administration was in the hands of a close corporation, often a body small in number; towns, too, where the administration remained in the hands of the townspeople. To the former type belonged generally the larger and older municipalities; to the latter, the smaller and more recent. There were towns in almost every stage of development between the widely different constitutions which have been indicated, a state of things whence arose anomalies and obscurities that gave embarrassment through many centuries, - to which an end was not set, indeed, until the reforms of 1832. Naturally this chaotic condition of the cities and boroughs affected the efficiency of their representation in Parliament. Often the member stood in no fair way for the body of men for whom he nominally sat. No wonder that as compared with the knights-of-the-shire, all deputed after one simple and uniform fashion by the county courts, and all in a certain way men of rank, the boroughmembers were at a disadvantage in undertaking the work of legislation.

In the case of the thoughtful man, interested in

The Chapter House at Westminster. reviewing the course of things which has resulted in the world that now is, the Abbey Church of Westminster, with all its beauty 
and great associations, will scarcely touch so deeply as the Chapter House elose by, plain comparatively in its adornments and proportions, which, in the early days we are now dealing with, beeame the regular meeting-plice of the recently constituted Parliament of England. It is a hall oetagonal in shape, with a massive central pillar rising high, to spread out at last into groined ares, whieh form, with similar ares proceeding from the sides, the lofty vaulted ceiling. The seats of stone about the columm and the walls are worn and made dark with many generations that have sat upon them. The floor is channelled deep with the footsteps that have trodden there. In the windows there is still old glass which must have let in light upon the faces of the great Edwards themselves, as, building so mneh better than they knew, they shaped, in anxious and troubled counsel with their Barons and the representatives of their people, the structure of the English legislature. No clear reeord las come to us of the debates that echoed from those walls. Could the stones speak, they might bear witness to struggles as memorable as those of a later time in Westminster Hall and St. Stephen's Chapel, whither the Parliament by and hy removed. As to details, little is to be recovered. In outline, however, the constitutional growth may still be tracel. In the first larliaments, the four orders, the clergy, the Barons, the knights-of-the-shire, and the burgesses, met each by itself, for the purpose of delileration. Soon, however, we Prisision of find the knights becoming alosely connected with the Baroms, ${ }^{1}$ by whom the knights were

'Sir T. Erskine May : Euryclopadia Britaunica, art., "Parliament." 
admitted apparently to an almost equal position with themselves, both as legislators and counsellors of the Crown. The clergy continued to hold aloof, while the burgesses took little part, except when they were to be taxed. But the position of the burgesses gradually improved. In 1322 their right to share fully in all legislative action was asserted; and soon, through some obscure cause, the knights-of-the-shire, giving up their community with the Barons, drifted over to the side of the burgesses, with whom they coalesced so thoroughly that the mited classes became known as the Commons. In 1325 is found the first recognition of the necessity of the assent of the Commons to making a law valid: it comes as an indorsement upon a proposed act. "It cannot be done without new law, which thing to do the Commons of the land will not yet assent." I In 1327, the young Parliament gave strong proof of its vigor in the deposition of Edward II. In 1341 came the definite division into two Houses, the Lords and Commons, which has existed until the present hour, and which is reflected in America, and in all other lands which Anglo-Saxon freedom has touched. It is hard to overestimate, says Green, the importance of this change. Had Parliament remained in four parts, jealousies would certainly have paralyzed its action. Had the knights and the Barons remained together, an aristocratic oligarchy could not have been escaped. The cause of the people derived an immense impulse when the knights-of-the-shire placed themselves side

I "Il ne put estre fait sanz novele ley, la quele chose fere, la comunalte de la terre ne vult my uncore assentit" (responsio in dorso). Guliel. Ryley : Placita Parliamentaria, p. 619. London, 1661. 
by side with the burgesses. Moreover, the knights, forming as they did a connecting link between the higher nobles and the people, bound happily together the whole national fabric. A new power was at once lent to Parliament which it lias never sinee lost.

Edward III, engaged in foreign wars, and, driven year after year to ask for grants, brought Parliament together in frequent sessions. With each grant the national eouncil took a step forward; the splhere of its action eontinued to widen; we find record of acts regulating trade, ehureh matters, and the general rights of subjects. The doctrines were emphasized that the King's needs could be supplied only by parliamentary grant, and that the King's ministers were responsible to the nation for power of Para faithful and honest discharge of their duties; at last from functions purely legislative, Parliament took hold of the work of administration. In the Good Parliament of 1376 , a most rigorous assertion of anthority took place. The Black Prince, sick unto death, was anxious to seeure the suceession to the throne of his young son, Richart. The probites at the same time stood opposed to John of Camut, and the latronial party of which he was the hearl. Edward III was in his dotage, and arainst the royal romeil, which alministered affars in his mame, the Parliament now fierecly arrayed itself. Sir Peter de lat Mare, the speaker, mate the walls of the ('hilpter. House ring with denunciations of military mismunagement, of olpressive taxation, of money spent withont rendering anconnt. Two ministers were impeached and condemmed: Aline Porers, the mistress who held in her control the inbeeile ling, wats 
banished; annual sessions of Parliament and free elections of knights-of-the-shire were demanded; arbitrary levies of money and the encroachments of the Pope were condemned. John of Gaunt opposed, to be sure, powerfully. De la Mare was imprisoned and the Good Parliament declared to be no Parliament. The great council, however, was by no means broken in its strength.

We are not to understand, however, that the Parliament, become so energetic, fairly represented the Its imperfect entire population of England. We have character as a
representative body. laborers, - a matter so interesting in connection with the story of Anglo-Saxon freedom that we must give the circumstances a eareful look. In Alfred's day, as has been mentioned, ${ }^{1}$ the number of freemen, or ceorls, had greatly diminished. The terrible Danish wars, when the life of every man was environed by perils, foreed the ceorls to "commend" themselves to thegns, receiving protection in return for a labor payment. Probably, thinks Green, whose view is here summarizcd, ${ }^{2}$ these dependent ceorls were the villeins of the Norman epoch, men sunk from pure freedom, and bound to the soil and to the lord, but still preserving many of their ancient rights. They retained, for instance, their lands, free as regards all men but their lords, and still sent representatives to hundred-moot and shire-moot. They were, therefore, far above the men possessed of no land, who in

1 p. 23.

2 Short History of the English People, p. 245, etc. See also Tuswell-Langmead: English Constitutional History, p. 291, etc. 
the Saxon day, having no politieal rights, were simply household servants or hired laborers, or at best rentpaying tenants of land not their own. After the eonquest, however, the Norman lords and their lawyers saw little difference between the two classes, and both tend to blend into the one class of serfs. All depended upon the lord, whose manor-house was the centre of the village, with the court in the hall, where justice was rendered and the estate administered, and the gallows outside for the extreme penalty. The lord's demesne, the home-farm, was close at hand, eultivated by the villeins or serts of the manor; so they paid their labor-rent for their holdings. They gathered their lord's harvest, ploughed and sowed for him, or provided his store of wood. All but the lowest serfs were at liberty, when work for the lord was done, to till their own holdings. The laborers must work for the lord throighout the year. These were at the lottom of the seale; for the absolute slave, to be found in the earlier period, hat now disappeared. It was the duty of the lord's bailiff to exilct from the villeins the proper amount of service; on the other hand, there was a reeve or foreman of the manor, chosen by the tenants themselves. who represented their interests and rights.

At length this system of tenure wis disturberl. The lord would let his manor to-a temant, and the rent paicl by the temant was called the rise of the feorm; hence farm and furmer. This prate- farmers and tice had a great indirect influence in hreak- borers. ing the fendal tie between the lord and the villein. An intermerliate cliss - these farmers - - imes up between the great proprietors and their dependents. 
The rise of the farmer class was presently followed by that of still another, - the free laborers. The influence of the Church helped to some extent to free the serf from land and lord. A year and a day in a chartered town, if the fugitive meantime were unclaimed, enfranchised him. Labor-service, too, at last, could be commuted for money. This the lords at first were glad to allow, for it gave them ready cash. Even the King, Edward III, on the royal estate, was glad to sell to his villeins freedom from their obligations. Thus out of feudalism, came up the yeoman, and his appearance modified the whole social condition of the country. On a multitude of manors, in the middle of the fourteenth century, the lords, instead of the old feudal methor, cultivated their estates by means of paid laborers, receiving money-rent from free tenants in place of actual work by half-enslaved villeins.

Now, however, intervened what, for that generation, was a terrible calamity. In 1348, the Black Death sweeping from the Levant across Europe, fell upon England, carrying off more than one-half of its population. Of the three or four million inhabitants at the beginning, scarcely enough were left to keep the country in many parts from reverting to wilderness. The villages suffered well-nigh as severely as the cities, until much of the land became almost a desert. At once the price of labor rose enormously ; and land-holders, and in the towns the master-craftsmen, were threatened with ruin. Forthwith, Parliament passed the Statute of Laborers, an enactment The Statute fully in the interest of the proprietary class, of Laborers. which forced every poor man " to serve the 
employer who shall require him to do so for the same wages as two years before the plague." It was also sought to bind the laborer again to the soil; he was forbidden to quit the parish where he had lived, in seareh of better wages, even though he had bought his enframehisement. It was probably impossible to enforee the law; but the high-placed were most persistent, and the statute was repeatedly re-enacted. The harboring in towns of those who had been serfs was vigorously put lown; a stop was set to the commutation of labor-service for money; manumissions and exemptions were eancelled on the ground of informality; finally, runaway laborers, when eaught, were branded upon the forehear with a hot iron. In the comitry, many who had once been villeins, but who had commuted the personal service due from them by money-payment, had become men of position and substance. 'These funding their dear-bought freedom questioned, lent a powerful support to the canse of those just enfranchised. Strikes and combinations disturbed everywhere borough and shire. 'The serf was wimning his freedom, while those who had been masters were trying hated to foree him back into dependence. Those lays are far behind us; lut here in free Ameriea that ancient struggle for liberty, and the heroes who fought and dien to serore it, omght not to be unknown. The eause was the same as that for which our own fathers bled amd alied ; its ahamponses wore the prototypes of the names we most lorere. Withomt dombt, a rertain liecense entered into the doxtrines whirh their loislers

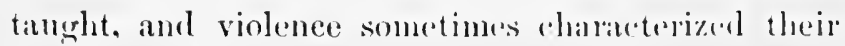
conduct. When has it been otherwise in times of 
revolution? Their cause was in great part just; and it was fought for not only with much bravery, but in the main with true forbearance and wisdom.

The priest, John Ball, preaching to thousands of the stout men of Kent, descendants of the ceorls who had The peasant been the vanguard of Harold at Hastings, rebellion. and still always foremost when England was in danger, gave utterance to ideas sometimes extravagant, but often full of natural equity. " "Good people," he cried, "things will never go well in England so long as goods be not in common, and so long as there be villeins and gentlemen. By what right are they whom we call lords greater folk than we? Why do they hold us in serfage? If we all came of the same father and mother, Adam and Eve, how can they say or prove that they are better than we, if it be not that they make us gain for them by our toil what they spend in their pride? They are clothed in velvet, and warm in their furs and their ermines, while we are covered with rags. They have wine and spices and fair bread; and we, oat-cake and straw, and water to drink. They have leisure and fine houses; we have pain and labor, the rain and the wind in the fields. And yet it is of us and our toil that these men hold their state."

Parliament, although in these very years it was boldly curbing the tyranny of the rulers as never before, became reactionary through fear of the widespread levelling and socialistic doctrines. As before it had legislated in the interests of the rich in passing the Statute of Laborers, so in 1380, by

1 Froissart: Translation of Thomas Johnes, Chap. LXXIII, etc. 
the imposition of a heavy poll-tax, which ground harshly the faces of the poor, England was set on fire from end to end. The homely rallying eries that passed from man to man have sometimes been preserved. "John Ball," ran one, "greeteth you all, and doth for to understand he hath rung your bell. Now right and might, will and skill, God speed you every dele." "Jack Miller," said the summons of another leader, "asketh help to turn his mill aright. He hath grounden small, small; the King's son of IJeaven he shall pay for all." "Jack Carter," declared another, "prays you all that ye make a good end of that ye have begun." "Falseness and guile," said Jaek Trewman, "have reigned too long, and truth hath been set under a lock, and falseness and guile reigneth in every stoek. True love is away that was so good, and clerks for wealth work them woe. God do bote for now is time." In these rude eries and songs, says. Green, ${ }^{1}$ we have the forermuners of the fiercely just invectives of Milton and Burke, instinet like the latter fuhminations with a longing for right rule and plitin justice, with a scorn for the immorality of the nobles and the infamy of the court. and a terrible resentment at the perversion of the litw.

Formidable insurrections broke out. The robels of Kent and Sussex marched upon london with such boldness and in such multitudes that opr Bearing of position to them seemed impossible. Rielt- Richard it. ard Il, latcly erowned. a boy of fiftcen, mitle a speech from a hoat in the Thames to the arowit on the banks. The youth in these dlays lore himself with

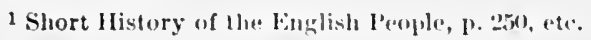


all the bravery of a true Plantagenet. His portrait as a young man still looks down upon you in the choir of Westminster Abbey, the earliest contemporary representation extant of any English sovereign. ${ }^{1}$ The cheeks are full and florid, the hair ruddy, the eye, one thinks, capable of frank and kindly expression, the figure kingly. The insurgent laborers felt kindly toward the handsome, spirited boy; but when those who surrounded him refused to allow him to land among them, they shonted angrily their war-cries, and along the lanes, full of the beauty of June, poured wrathfully toward the great city. The poorer artisans opened the gates to them; at once fire was put to the palace of John of Gaunt, the head of the brutal nobles; to the houses of foreign merchants, for there was a vehement, probably an unreasonable, hatred against things un-English; and also to the quarters of the lawyers in the Temple, for whom there was especial clislike, as the class from which were drawn the manorial stewards, the usual instruments of oppression.

In this rising, declared by Stubbs to be one of the most portentous events of English history, the most Wat Tyler noteworthy leader was Wat Tyler, of of Essex. Essex, a man of excellent purposes and ability, however rough. In the revolt, he tried hard to impose upon his followers a wholesome discipline; a plunderer carrying a silver vessel from the burning palace of John of Gaunt was himself thrown into the flames. By such sharp reminders he taught his men that the effort in behalf of better justice could not be served by thieves and robbers. There is some

1 Stanley: Memorials of Westminster Abbey, p. 147. 
reason for supposing he cherished a high plan for the overthrow of feudalism and a restoration of the old government of counties and distriets, through the ancient moots of the people; in a word, Anglo-Saxon freedom. The seheme in that day was wild and premature, but in the stout-hearted laborer may be beheld some of the traits of a Cromwell. ${ }^{1}$ His hour soon came. The crowd of rebels, no doubt rough and unsavory to the last degree, overran London, browbeating courtier and eitizen. At the Tower, they took by the beard in rude horse-play the knights of the royal household, declaring that heneeforth they were to be fellows and comrades; but presently after, in the Chapel of St. John (the Norman arehes of which, together with the gray columns and ancient carving, the visitor may still admire), they found lurking the Archbishop of Canterbury, against whom they cherished an especial spite. He was haled from sanctuary, and at onee beheaded; nor was that the only homicide. "We will that you free us forever," eried a nultitude, meeting the King in the streets, "us and our lands; and that we be never named nor held for serfs." "I grant it," saicl liehiard, and bade them go home, pledging limself to issue charters of freedom and ammesty. On June 15th, Richard and Wat Tyler eame face to face at simithfield. During the interview, Walworth, lord mayor of London, struck the popular champion dearl with a sudilen thrust of his dagger. "Kill, kill!" thumbered the erowd. "They have slain our eaptain!" "I am your eaptain and your king," cried yomng licharrl,

$1 \mathrm{~J}$. Thorold Rogers: 1listory of Agriculture and P'rices in lisiglind, I, p. 94. 
riding promptly and fearlessly to the front of the crowd. "Follow me." They followed him loyally and trustingly; for the people had a firm faith that could the sovereign be but separated from evil counsellors, their grievances would be fully redressed. Richard promised faithfully; a throng of clerks was Treachery of set to work to prepare charters, which were the King. issued by the seore, securing to their receivers ample rights. Only treachery, however, was in the minds of the King and his nobles. When the insurgents were dispersed, at the earliest safe moment the sternest vengeance was exacted. The pledges were broken; fire and sword raged throughout the land. Seven thousand died on the gallows and in the field.

A few incidents are related of that time of blood, showing how true was the temper of those strivers for freedom, At St. Albans, for instance, near London, the rule of the great abbey over its tenantry had been most oppressive. In the uprising, the laborers had obtained a charter, and full of joy, they tore from the pavement of the cloisters the mill-stones, which were laid there in token that grain could be ground nowhere on the demesne but at the abbey mill; these were broken to pieces in proof of the emancipation, "like blessed bread in church." When the rebels, taken at disadvantage, were put down, William Grindecobbe, their leader, was offered his life if he would persuade the St. Albans men to restore the charter. He bravely bade his followers to take no thought for him. "If I die," he said, "I shall die for the cause of the freedom we have won, counting myself happy to end my life by such a martyrdom."

When Richard was reproached for his faithlessness, 
he answered, with an insolence as precocious as the cool self-possession he had shown in the time of danger: "Villeins you were, and villeins you are. In bondage you shall abide, and that not your old bondage, but a worse." It is melancholy to read of the conduct of Parliament in this crisis. Assembecratic Assembled on the suppression of the revolt, temper of the Parliament was met by a royal message, Parliament. indicating a willingness to yield. "If you desire to enfranchise and set at liberty the serfs by your common assent, as the King has been informed that some of you desire, he will eonsent to your prayer." But the Parliament was stern. The King's eharters, it was answered truthfully, were legally null and void, as not being authorized by the national comneil. "Their serfs were their goods, and the King could not take their goods from them but by their own consent; and this consent we have never given and never will give, were we all to die in one day." 1

The eamse of the revolted villeins seemed to go lown in bloor, but really a vital blow harl been struck at villeinage, and the eomolition of the laborers imporoved. In spite of violones and threats from those high in place, the process eontinued, the elatsis of yeonen being steadily recruted form those eoming up from below.

"When Adam detred and bre span,

Who was then the gentlemin?"

the question asked in all the shops and fiolils of

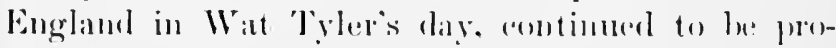
pomeled, themgh perhaps moler the hreatle, and the

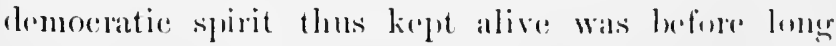
again to show itself.

1 (ireen: Short History, pl. 25, 25. 


\section{CHAPTER VI.}

\section{THE TIMES OF THE LANCASTRIANS.}

$\begin{array}{ll}\text { Henry IV, 1399. } & \text { Edward IV, 1461. } \\ \text { Henry V, 1413. } & \text { Edward V, 1483. } \\ \text { Henry VI, 1422. } & \text { Richard III, 1483. }\end{array}$

Arong the sovereigns of England, Richard II has the unenviable distinction of entertaining the most Deposition of extreme notion of the royal prerogative, Richard II. and of having urged most strongly the idea of hereditary succession, as opposed to the popular choice. He tried to make himself absolute, striking at the very root of the freedom now in process of revival. Aiming at a recognition of despotism, he tried to supersede Parliament by a commission. In Parliament there was little representation as yet of the humbler classes. So it was to be for many centuries, -in fact, until the influence of American example began to be felt. Nevertheless, it stood, however imperfectly, for the nation, and in these days was determined not to crouch before the King. When Richard II therefore claimed that the nation must provide for him whether he behaved well or ill, - that, as supreme law-giver, he could dispense with a statute, alter its wording, or revoke it entirely, that he might, in fact, do away with any institution interfering with his theory of sovereign right, Par- 
liament, in 1399, deposed him, and chose a prince of the Laneastrian line to rule in his Power of Parplace. In this suceessful assumption of liament. right, Parliament raised itself to a position searcely inferior to that which it vindieated for itself two hundred and fifty years later, against the oppressions of Charles I. By suceessive steps the Commons had become the active and aggressive force of the national eouneil. At first, "Tos humbles, pauvres Communes prient et supplient pour Dieu et en cuvre de charité," that their petitions may be granted. Soon they establish the principle that no grants can come until grievanees are redressed. They next elaim the right to examine the royal aceounts, to regulate the royal expenditures; and at last they hold responsible to themselves the ministers and depose the King. ${ }^{1}$

At the aceession of Henry IV Parliament seemed likely, indeed, to become supreme. In 1406, the demands of the Commons and the coneessions of the King, who, aware that he owed his dignity to parliamentary eleetion, dared not withstand the legislature, amounted almost to a supersession of royal anthority. Never before, and not for two hundred years after, were the Commons so strong as under Henry IV, and among them, as before, the leaters were the sturly knights-of-the-shire. A long step was talken in this reign toward a recongnition of the important principle that money-grants must originate in the lower Ilouse. But the llouse of Commons wats more and more losing tonch with the prople. To be sure, the knights-of-the-shire were still alected in the old shire-moots, every freeman having a voine, thomerh in

IHannis Taylor: Origin and (irowth of ling. ('onst., I, J. AH. 
the case of the poor and landless the voice was scarcely appreciable. The functions of the shiremoots were becoming, however, greatly restricted. As early as the reign of Edward III we find side by side with them in each comnty the Court of Quarter Sessions, made up of justices appointed by royal fiat, and these were fast alssorbing all judicial and administrative powers. The time was coming when the broad suffrage of the shire-moots was also to be greatly curtailed.

Henry V was a great constitutional King. Probably nation and sovereign have never been so completely at Popularity of one as under him. A glamour surrounds Henry v. the second Lancastrian such as attaches to no other sovereign of England. He was the ideal of Shakspere, in whose portrayal of him, first as Prince $\mathrm{Hal}$, and then as a brilliant, heroic leater, all the resources of the most consummate genius are lavished. Shakspere had, unmistakably, as a subject for his picture a man of noble qualities, and probably has not greatly exaggerated the traits. Sober history is scarcely calmer in its eulogy than the lines of the poct. Into what he might have matured had he lived longer, no one can say; but no King so holds the hearts of the English-speaking race, with the possible exception of Alfred, as the young victor of Agineourt. It is an interesting moment for any thoughtful man, when, with his mind charged with the immortal Shaksperian delineations, the wild fiolicking with Falstaff, the chivalric prowess at Shrewsbury, the camp-fires in Picardy, by which "each battle sees the other"s umbered face," the deeds the next day of the men whose hearts were in trim though " there was no piece 
of feather in the host," - he stands before the headless effigy in Westminster Abbey, and looks up at the relies above, - the spear, the saddle, the helmet, so far to the front with the King in the mêlée, when the knights of France underwent such humiliation. Like his father, Henry $\mathrm{V}$ knew well that he harl no title except that he had been ehosen by the nation to rule. Parliament was beeming oligarchical; Henry was more democratic even than his Honse of Commons, asserting often the rights of the unrepresenterl against elass-legislation. ${ }^{1}$ He was the idol of high and low. He gave himself to the nation, and the nation took him to its heart, surrendering itself to his leadership with full confidence in his capacity and good-will. The knights-of-the-shire upheld him in the deliberations of the Chapter House; the people poured money into his coffers, making nothing of the heary sums, because the right to give and the right to withhold were fully recognized; the children of the people, "the good yeomen whose limbs were made in lingland," 2 proved abundantly on foreign fields" "the met tle of their pasture," making light, for the sake of surh a King, of eold and hunger and hard matreling; while on the battle-day, as matehless arehors, they pierced the panoply of the best ehivalry of Europe to such effect as almost to destroy France.

Evil days, however, were at hind. The world wats not ready for parliamentary geverument. With the Lancastrians, it seemed at first on the point of lecing

1 Church: Henry V, p. (r).

2 The tifteenth century was the gohlen age of the Finglish yeomanry, a degree of social equality then "xisting smelt as has not often be'th wit -

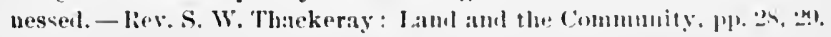


realized, but a reaction set in. "The Wars of the Roses," says Comines, found England, "among all the world's lordships of which I have knowledge, that where the public weal is best ordered, and where least violence reigns over the people." An English King "can undertake no enterprise of moment without assembling his Parliament, which is a thing most wise and holy, and therefore are their Kings better served" than the absolute sovereigns of the continent. ${ }^{1}$ Just as the Lancastrian power was Fortescue on the English constitution.

passing away, and the House of York was becoming supreme, a great judge, Sir John Fortescue, set forth in noble terms the constitutional view of the dynasty which was perishing. The King, he declares, exists for the kingdom ; not the kingdom for the King. His power is derived from the people, without whose consent he can neither change the laws nor impose taxes. The good King rules, not from the desire of power, but to take care of others. The origin of kingship is the will of the people; and though its conservation is secured by hereditary succession, yet righteous judgment is its true sustaining power and justification. The King is not only a sovereign lord, but a public servant, - not less than the Pope, a "servus servorum Dei." 2 Under the Lancastrians, the right of the Commons to share in legislation of every kind and to debate freely all matters of public interest was admitted. The two Houses of Parliament were regarded as co-ordinate, equal, and mutually dependent assemblies. While the Lords held judicial power, the Commons originated grants.

1 Quoted by J. R. Green: History of the English People, II, p. 5.

2 Fortescue: De Laudibus Legum Angliæ. 
Freedom of discussion in the lower House was not to be interfered with; no member was to be called to account for words spoken in debate. The House of Commons in theory now and long afterward represented fully and fairly the nation.

Unfortunately, theory and practice did not coincide. Indeed, the people themselves seemed to hang back. The constituencies of ten regarded the sending of members to Parliament as a burden, and those elected often went unwillingly. In Henry Vth's day, their trust in the sovereign was so great that they did not care to assume the burden of self-government. The times when public spirit is most vivid are times when tyrants most oppress. Kings weak and wicked are sometimes greater benefactors than the strong and good.

Notwithstanding that Parliament now had asserted itself so strongly, we have to notice the fact, at first view vudden decay fact, at first view very remarkable, that the of the power nation suddenly in its progress exlibited

a reactionary spirit from which it liel not recover for a century and a half. The ehange, though surprising, is explicable. In the first place, widespreal compunction had been felt on account of the deposition of Richard II. That the King should be hereditary as well as elected was ingrained in the ideas of the time. Richard had believed that

"Not all the water in the rucle, rough sea

Can wash the balm from au anointed king."

and multitudes of his suljects were far from leing indisposed to aequiesee. Thomgh the dowtrine of the jus divinum, the divine right of the next of kin to be 
chosen, was by no means as yet established, there was a tendency in that direction. The uneasiness felt by the people over the treatment of Richard was regarded by them as an admonition of conscience; and when after his speedy death the memory of his unworthiness died out, and the disposition grew stronger and stronger to credit him with virtues that he did not possess, repentance became deep in the hearts of many on account of the deposition of 1399 . The Lancastrian Kings themselves probably shared with the people this uneasiness. Shakspere makes it one element of the heart-break of Henry IV that he felt his occupation of the throne to be unlawful; and in the most critical moment of the career of Henry V, the night before Agineourt, he vows nothing more devoutly than to provide masses for the repose of Richard's soul. The strong qualities of the first Lancastrians kept this remorse in their subjects in check; but when Henry VI succeeded, a prince under whose weak sway great suffering had come to pass, the sentiment rapidly grew, preparing the way for a noteworthy enhancement of the power of the King, which we shall presently have to notice.

In the second place, the House of Commons now took a course which greatly depressed its character.

Misfortunes

In 1429 , a statute was passed restricting of representa- the franchise, the most reactionary meas-
tion in the toon inter shire and
boroughas. ure, says Freeman, ${ }^{1}$ ever taken by a Parliament. Complaint is expressed that county elections have been made by "a very great, outrageous, and excessive number of people dwelling

${ }^{1}$ Freeman: Growth of the English Constitution, p. 101. TaswellLangmead: English Constitutional History, p. 340, ete. 
within the same counties, of which most part was people of small substance and of no value, whereof every of them pretencled a voice equivalent, as to such elections to be made, with the most worthy knights and esquires dwelling within the same comnties." To prevent, therefore, "the manslaughter's, riots, batteries, and divisions," which were likely to take place, no one was to vote who did not possess "free land or tenement to the value of forty shillings by the year, at least, above all charges." Forty shillings in that day was equivalent to forty pounds at present; the execution of the law led to a widespread disenfranchisement of poor men.

While calamity thus fell upon the shires, the largeness of borough life began also to be much curtailed. Charters were procured from the Crown, which turned many boroughs into close bodies, excluding all from the franchise who were not burgesses by birtl or long apprenticeship. Borough-moots generally had disappeared, giving place to comncils which were either close corporations or the members of which were elected solely by the wealthier hurgesses. The new charters, for the most part, conferred the right of choosing the parliamentary representatives upon these commeils, or upon a still more restricted borly called the "select men," appointed from the commeil. Here began the process of chegratation, which. before longr.

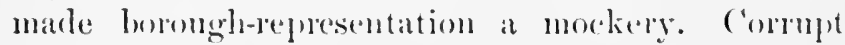
influences found lere an rasy oplentmity. The small electing clipues (ould easily be bouglit mp or intimitaterl, or in some waty eajoled hy the grmat mobles, land-owners, or the ('rown. Hemee the representatives wele often hut momineses and reattmes 
of the powerful. The boroughs were seized on by the great as their prey, by means of which they could send to the House of Commons their subservient instruments. As has been seen, the borough-representation in the lower House had not from the first been as efficient as that of the shires. From the time we have reached it deteriorated, the members standing in no proper sense for the populations in whose name they held their places. In the constitutional history of our race no abuses are more inveterate than those arising from this cause, abuses not remedied until the time of the younger Pitt and Lord John Russell.

Since both in shire and borough so little account was taken for a representation of the people, Parliament shrank fast into the shape of an oligarchy representing only the rich and powerful, and prepared to become the subservient tool of the sovereigns. All this abuse did not pass without protest. Hitherto, all suitors who had attended the sheriff's court had voted without danger of challenge for the knights-ofthe-shire. Nothing in the land was more ancient than those venerable moots. For more than a thousand years the forefathers had gathered from hundred and tithing, and every land-holding man had had his voice. When Earl Simon called into being the House of Commons, this general suffrage underwent no abridgment. In electing the two "discreet knights," even the villeins had had an influence, though it might be small. To some extent, the knights-of-the-shire were genuinely representative of the people, and the steady advance of the House of Commons into power, as the middle ages give way 
to the modern era, was due to their effective leadership. In Wat Tyler's day there seems to have been in Parliament a small minority who stood even for the very poor. ${ }^{1}$ The gulf was now widening between high and low, and the low-born soon found a champion.

History has too often portrayed unfairly the mediæval uprisings of artisans and laborers, doing the scantest possible justice to the leaders who Jack Cade's stood in the fore-front of danger, often rebellion. giving their lives to their cause. The Froissarts and Monstrelets find nothing attractive in the citizen or cultivator as compared with the brilliant knight, and pass him by with a curt word of contempt or even hatred. When poetry conspires with history to belittle and malign, we may well feel in our democratic days that hard measure has been accorded, and it is a grateful task to say a word on the other side. When Jack Cade, in 1450, at the head of a multitude of poor men, grandsons of those yeomen of lient whom John Ball had fired for the maintenanee of their rights seventy years before, burst into London and held the eity at his merey, Shakspere, drawing a picture for the aristocratic patrons of his theatre, portrays him for us as an mornly ehurl, whose eanse had no dignity, and who, if he had suceederl, would have instituted a reign of eoarse-ticense. We have, as we read, no sympatlye with him or those whom he led when the revolt is rotled bark, and Aleximler Iden takes the life of the miscrable fingitive. But the rising of which Jaek Cade wats the centlal figntre, like that of which Wat Tyler was the central figure,

1 See the speech of Richarl 11 to l'arliament, p. 7!. 
was really provoked by grievous oppression, - by unjust and harmful innovations upon the old order of things, against which the mass of the people sturdily but vainly braced themselves, no revolutionists, but thorough conservatives. "It was sought to draw a distinction between gentlemen and other people," they complained; declaring, moreover, "that the people of the shires are not allowed to have frec elections in choosing knights, but letters have been sent from divers estates to the great nobles of the county, enforcing the tenants and others to choose other persons than the common will is."

The protest failed of effect; the ancient freedom was pushed back; the people struggling for a liberty Justice of bis once their possession were roughly beaten cause. to the earth. It belongs to us to think of them and their leaders not contemptuously, but compassionately and reverently. When we have had in our imaginations that scene in Smithfield, in which the lord mayor of London struck with his dagger Wat Tyler, asking for a redress of grievances at the head of his peasant army, admiration probably has flowed toward the brilliant young King whose coolness and address turned the incident to his own advantage; and not toward the man, who, by sorrow over the woes of the land, had been called from his humble toil. The soul of Richard, however, was black then with cruelty and treachery, and he speedli? matured into a tyrant; while his victim, it is now declared, possessed the sturdy virtue and much of the ability of a Cromwell. So, too, we can read between the lines of calumniating chroniclers traits of the hero in Jack Cade. We pause reverently under the old 
elm at Cambridge, in whose shadow flashed the sword of Washington as he stood at the head of the yeomen who were to bring to grief, in the eighteenth century, prerogative and privilege. Why not stand with similar reverence before "London Stone," built into the ehurch founclation there in Cannon Street, which tradition says was touched by the sword of Jack Cacle? He, too, stood at the head of an army of yeomen, like Washington's host, hard of hand from the flail and the plough-handle, beaten by the weather as they wrested from the earth their food and raiment. Indeed, the lineal forefathers of Washington's men at Cimbridge were, to some extent, those very men of Cade. 'The cause in the two cases was substantially the same. Each leader was a striet eonservative, striving to vindicate from encroachment inmemorial riglits, "pon which those high in place hat laid sacrilegrioms hamds. To one the fittes were kind, and his name is among those most honored of men. The other fatiled the was hunted to his death, and upon his grave hats been heaped little lut eontumely. The fulness of time hats come; the people, in whose behalf these laders strose, has becomes sulmeme. Will not the preople aceowl to the vietims somedhing of the honor whith it hats bestowerl nuen the vietors?

buring the Wars of the lioses the laturastrian power went down, while the Honse of lonk, in the

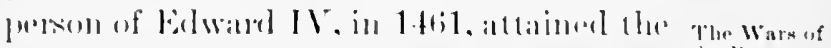

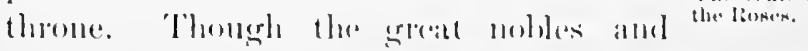

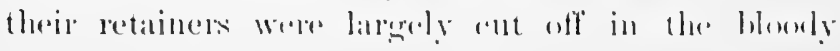

This was eqperially the case, perhaps, at regith the men from

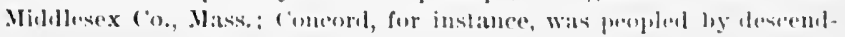
ints of yeomen of kent. 
battles, the nation at large suffered surprisingly little, undergoing slight disturbance, enjoying, indeed, a certain amount of prosperity even while the armies clashed. Naturally, the power of Parliament in these years rapidly died down. While the Lords were to such an extent destroyed, the Commons, through causes which have been detailed, became obsequious. The more the upper middle class stood out as gentry, and after the wide disappearance of the high nobility became an important body, the greater became the separation between the upper middle class and the orders below them. Parliament had become mainly the representative of the gentry. The lower mass, deeply estranged by the injustice and contempt visited upon them, were more disposed to trust the King than those who had thrust them down. It is easy to see why there was no murmuring when Edward IV, neglecting almost entirely the ancient ceremonics of election and recognition, claimed to be the rightful King solely as the heir of Richard II. It was, says Stubbs, a complete legitimist restoration, the proceeding presenting the strongest possible contrast to that at the accession of Henry IV, two generations before. Edward went on as he began; parliamentary action was suspended for years together, and during the whole reign, for the first time in English history, there was no sirigle enactment for increasing the security or liberty of the subject. Richard III, sustained by no proper title, catching at every straw to keep himself afloat in his ill-gotten dignity, sought a recognition from Parliament and from the citizens of London, but it was a farcical travesty of the solemn and venerable form of election. 
With the old Baronage destroyed and the political strength of the Commons so far gone in decay, the strength of the Crown at the end of the Accession of fifteenth century was nearly doubled, a the Tudors. change so marked as to be little short of a revolution. At the very hour when Anglo-Saxon freedon seemed about to be irreeoverably lost, eertain Bristol ships piloted by Venetian sailors, the Cabots, father and son, touched, first of civilized men, the shores of a vast continent to the west. In that continent, for the first time, freedom was to have its full recognition and development; largely through influences going back from that continent, freedom for the motherland also was, after centuries of cloubt, to be fully seeured; - for the mother-land and also for mighty Anglo-Saxon peoples in the ends of the earth. 


\section{CHAP'TER VII.}

\section{DEPRESSION OF THE POWER OF PARLIANENT.}

$\begin{array}{lll}\text { IIenry VII, 1485. } & \text { Edward VI, 1547. } & \text { James I, 1603. } \\ \text { Henry VIII, 1509. } & \text { Mary, 1553. } & \text { Charles I, 1625. } \\ & \text { Elizabeth, 1558. } & \end{array}$

WE have reached now the period of the Tudors. When Henry VII acceded to the throne, in 1485,

but twenty-nine Lords were left as a remof the power nant of the old nobility; a continual hu-
of the Crown. miliation of the weakened Baronage was a main object of his policy, which he had no difficulty in following out. The growth of the royal authority became with Henry VIII portentous, a sudden acceleration taking place in consequence of the extinction of still another power, which heretofore had done much to keep it in check. In our narrative, it has been made apparent that in the Lancastrian epoch and the years just preceding, the champions of freedom were in the main the knights-of-the-shire. Still earlier the Barons, in the time of Magna Charta and the reform of Simon de Montfort, by wresting from nascent despotism a portion of the nation's rights, improperly alienated, gave the popular leaders the vantage-ground without which they would have failed of opportunity. In a time yet earlier, it was the Church that had stood foremost in the contest for liberty, its policy during the early Middle Ages, 
against the violence of William Rufus, the confused lawlessness of the reign of Stephen, the cunning of Henry I, constituting one long protest against the predominance of mere brute strength. I It was due to Langton and the ecclesiasties mainly, indeed, that the Great Charter contained so many popular features, though the Barons then were coming into the foregromul. In faet, until the period we have now reached, though less prominent, perhaps, in the later centuries than the earlier, the Chureh is to be found at the right hand of every influenee that tended to thwart oppression. It upheld the effort of the martyr of Evesham, whom it was almost ready to eanonize; in the person of the humble priest, Jolnn Ball, it was at the side of Wat Tyler; in Wickliffe and his followers, who, however unorthodox, were, nevertheless, cowled and tonsmed priests, it stimulated powerfully the impulses toward freetom which throbbed in the hearts of the people. As the Baronage had become impotent, so the C'hurch was now to be stricken down.

Henry VIII divoreed Fingland from Rome, destroying, as he did so, the monatstir system and appropriating one-thind of the revenues of the laffect of the ('hurch. Ile comstrueted a new nolility, Reformation. composed largely of new men whom he anriched from the spoils of the Church, who natually were most obsequioms, disposed to defond to the last the order of things to which they owed place and pelf. He obtained a lex regree to make him suphome? lawgriver; and though he was politie as to interfering with l'arliament, he contrived to bring it alsumt. that 
Parliament did little more than register his decrees. Church and State were now under one over-lord. ${ }^{1}$ Through the Reformation, the Crown had won a quite new and most independent position. In the domain of the Church, the Sovereign as Defender of the Faith, replacing the Pope, ruled as absolute head, with a hierarchy of ecclesiastics in subordination to him, bishops, canons, and priests. In secular matters, his authority, according to the constitution, was associated with that of the nation represented in the Parliament, which possessed the power of making the laws. The House of Lords, however, were mainly the King's creatures; the House of Commons, through abuses in the borough representation and the restriction of the franchise in the shires, had quite lost its old force. Here also was open to Henry a door to absolutism through which he was not slow to pass. He was astute as he was audacions, and his reign was marked by certain excellent features which caused it to be endured, which even made it popular.

Henry should be treated fairly by the modern world. He can hardly be cleared from the charge of being brutal, rapacious, and tyrannical. He broke the hearts and cut off the heads of noble men and lovable women who had served and esteemed him faithfully. In the matter of the dissolution of the monasteries, the spirit that animated, and the means that were employed, were. worse than questionable. If the claim of the Anglican Church, that it was born in the days of St. Augustine, be granted, yet at its re-birth, under Henry VIII, it can scarcely be denied

1 Gneist is here for the most part followed: Geschichte und heutige Gestalt der Aemter in England, p. 180, etc. 
that some unpleasant figures stood about the eradle. The redoubtable Spenserian giant, Kirkrapine, was a valiant defender of tender Anglieanism. What would have become of it under Bloody Mary, had it not been stoutly upheld by Henry's new nobles, living on lands and supported by rents sequestrated from the monasteries, lands and rents sure to revert to their former owners had Rome once recovered her lost ground? ${ }^{1}$ Again, eonld Henry have had his way, he would have made himself a eomplete despot. Froude, without doubt, has estimated him too highly. Still he was patriotic, in a cer- Position and too highly. Still he was patriotic, in a cer- character of tain way well-meaning, most attractively courageous, and sometimes wise. Anticipating what is called in our day enlightened despotism, ${ }^{2}$ the royal authority prohibited what in times since has often become a erying evil, the rlepopulation of the land by over-large estates and the changing of arable into pasture; earnest care was shown for education and the welfare of the poor, for ammsements and exereises in arms, for guilds and trarles-mions. Less suceessful, probably, were IIenry's efforts to regulate the rate of wages and the price of provisions, and his prohibition, in the interest of the poor, of inventions likely to displace hand-labor. His intentions, however, were here the hest; and if he was in crror, his were errors which the world has not yet outgrown. He had to a marked degree that eharacteristic of a great ruler, the power of choosing instruments, and he cansed it to inure fully to the welfare of his realm. His offeials, high and low, were skilful, and to carch

\footnotetext{
1 Green: Short 1 istory, pp. 350,351 . Taswell-Langmead, p. 4.5.
}

${ }^{2}$ Aufgeklïrter Despotismus. 
was assigned, with good discrimination, the work which he could do best. For all this, it is certain that a grateful echo came from the folk, and unfeigned admiration from clear-seeing contemporaries of a higher intelligence. A consequence of these traits of Henry's rule was a condition of internal quiet, comfort, and prosperity in city, borough, and Good points shire. Bluff Harry, in spite of the enorof his reign. mities of which he was guilty, got very near the popular heart. His Parliament was not so much subservient, as disposed of its own will to acquiesce in what the King imposed. His procedure, arbitrary, but in great part well intended and often beneficent, had in it so much of good that the disposition grew strong among men to overlook the bad. It is to be noticed, as the special constitutional change of Henry's reign, that the House of Commons acquired a preponderating influence over the House of Lords. ${ }^{1}$ As compared with the authority of the King, the authority of Parliament seemed nearly superseded. In a hundred years, the political pendulum had swung through its entire are; for, in 1406, under Henry IV, with his doubtful title, the power of Parliament had seemed on the point of superseding that of the King. ${ }^{2}$ A dose of misrule was needed to set the nation right.

Misrule came soon after Henry's death, with his danghter Mary. A Catholic herself, she married the

Catholic reaction under Mary. prince afterward Philip II, soon to be the head and front of Catholic Europe. England, however, had turned its back definitely upon the ancient faith, and when Mary

1 S. R. Gardiner: History of England, I, p. 7.

2 See p. 81 . 
entered zealously upon a reactionary course, it beeame at once apparent that the spirit of the nation was not dead. Once more the prompt men of Kent, deseendants of the ceorls who had formed wratt's re. the vanguard of Harold at Hastings, and bellion. of the poor, plain men who followed Wat Tyler to Smithfield and Jack Cade to London Stone, thronged after Sir Thomas Wyatt, out of their tithings as far as Temple Bar, in formidable rebellion. Wyatt's rebellion failed, and its leader was beheaded, but it was not without effect. The blood of many martyrs became prolific seed, as well for a better state as a better chureh. Mary's days were short; but when Elizabeth aeceded, in 1558, Protestant though she was, she found in the people a temper quite different from that which her father hat known. Not only Mary Tudor and Philip, but Mary Stuart, also, were promoters of Anglo-Saxon freedom. The struggle with Catholicism foreed Elizabeth to have more frequent recourse to Parliament; and as she was driven to appeal for increasing supplies, the tone Increasing of the IIonses rose higher and ligher. The Commons were not now satisfied to Elizabeth.

restrict or help the Sovereign, lont assimed to dietate a policy. Elizalneth angrily eharged them with acting like relels, with dealing with her as they dared not have dealt with her fither. 'To the Spanish ambassador she said, "I cannot tell what these devils want." "They want liberty, Mitlane," said the Spaniard; "and if princes do not look to themselves. and work together to put sureli preople down, they will find before long what all this is coming to." Parliament was now fully conscious that it stood 
for the people, as appears from the declaration of Sir Thomas Smith: "Every Englishman is intended to

Sir Thomas Smith's de. scription. be there present either in person, or by procuration and attorney, - of what preeminence, state, dignity; or quality soever he be, - from the prince, be he King or Queen, to the lowest person in England; and the consent of Parliament is taken to be every man's consent." 1 Elizabeth, however, followed as closely as she could in the footsteps of her father. By natural temper the Tudors were more arbitrary than the Plantagenets; and had a standing army been at their disposal the utter destruction of liberty might have come. ${ }^{2}$ ElizTact of the abeth, like Henry, though easily roused to Queen. wrath and full of arrogance, was yet sincerely patriotic, possessed tact and an excellent gift in choosing good men for office, to whom she was generally faithful. Cecil's management was prudent, economical, benevolent, in fact, almost motherly, ${ }^{3}$ in its care for all classes. She asked for very few subsidies, and in every conflict with the parliamentary right to legislate and tax, though she might storm and swear, she at last yielded.

The main laws of Elizabeth's system were the Act of Supremacy and the Act of Uniformity, laws Acts of $\mathrm{Su}$. premacy and Uniformity. in the worst possible odor with writers in sympathy with the struggle for freedom, and whose purport, on account of the important part they have in the history of the

1 Quoted by Stubbs, III, p. 468; for other similar assertions, see Taswell-Langmead : English Constitutional History, p. 484, etc.

2 Macaulay: History of England, I, p. 31.

8 " Mütterlich," Gneist, p. 213, etc. 
succeeding century, must be carefully pondered. Though they tended strongly toward despotism, their enactment by a Parliament in which the sentiment of liberty was well alive, is quite explicable. $\mathrm{By}_{\mathrm{y}}$ the Act of Supremacy, all spiritual or ecelesiastical law-giving was declared to flow out from the Throne, and an oath acknowledging this was required of every subject. By the Aet of Uniformity, Church ritual and discipline throughout were also subjected to the 'Throne. Bishogs held their places only during the Sovereign's pleasure. The bitterness of the strife with Rome male this alsolutism possible; the nation so dreaded a return of the days of Mary, that it acquiesced in the assumption, by Protestant hands which it could trust, of an mulimited spiritual sway. But the arlitrariness sonn began to eneroach upon the secular domain.

The instruments for making the increased royal power more effactive were the Star Chamber and Iigh Commission Courts. An imnoration into the constitution, fitfully appanent dluling the later midlle ages. but becoming Star Chamber and lliel, commission courts. fixed under the 'Turlous, was the Prive Comucil, a pure outcome of the royal will. lunder IInory VIII it consisted of fomrteren state and court officials, among them four peres and two bishops. The ('ourt of Sitar chamlrer, so-alled from its place of meoting at Westminster, was a committer of the l'riy ('mucil appointed to deal with secular affairs. 'The power of this court tended constantly to berome erreatere: but though quite manthorized hy the nation's roides and responsible to no ond hut the sovereign, it was at first negligently suffered. In Elizabethis lay. it was 
especially fearful to evil-doers high in station, and therefore for a long time popular. Usually it was impartial, disposed to protect the poor and oppressed, - with one important exception, however, when the person or passions of the Monarch came in question. The High Commission Court was a committee charged with spiritual cases. Here, too, the irresponsible power tended to become absolute. The Court differed from the Romish inquisition only in having a milder code of pumishments and a less violent method. Its arbitrariness was overlooked in the stress of the conflict with the dreaded religious foe outside, against which it was often an effective engine. These two committees, mauthorized by the Parliament, which had grown weak and negligent, became before long apparently irresistible. Publicity was excluded in their proceedings; torture was sometimes resorted to. How the Star Chamber and High Commission Courts were at length challenged and finally swept away must be told hereafter.

The return to arbitrary rule under the Tudors was not complete, then. Why it proceeded as far as it absolutism did we can easily understand. The disorrestrained
under the Tu- ders of the fourteenth century had wrecked dors.

the ancient Baronage and greatly injured the people at large. In England the Reformation helped the royal power. The sleep of the nation was promoted by the general popularity of Henry VIII, of Edward VI, and of Elizabeth, which was marked, in spite of their faults; - by the substantial wisdom, moreover, with which they used their alssolutism, steering skilfully the ship of state in the most difficult seas. Even in Elizabeth's reign, in spite of the 
danger imminent from the Star Chamber and High Commission Courts, the House of Commons made gains. Step by step it won the freedom of its members from arrest, save by its own permission; the privilege of punishing and driving out members for crimes committed within its walls; of determining all matters relating to eleetions. The more important elaim for freedom from arrest for words spoken in debate was not fully gained, Sir Philip Wentworth, its most prominent champion, seeing in eonsequence the walls of a dungeon. 'Two years before the Queen's death, the bill for the abolition of monopolies passed, which put an end to great alnses, the Queen opposing with her usual temper, but yielding at last with her usual taet.

As regards the power of the people, the sixteenth century was thronghout Europe a time of misfortune. In Spain, Charles V and Philip II over- Its triumph threw the cortes; in Germany, the desper- everywhere ate struggle of the peasants for a better tinent. condition proved utterly ahortive; in France, the anthority of the States-(ieneral dwindlerl, and carly in the seventeenth century the long intermission of their sessions hegan whieh ended only with the Revolution in 1789. Iolland, indeed, fought its way through to a measure of freedom ; and in England, though Tudor absolutism seemed to latve superseded all other rule, the spirit of the nation was not deald. Before long, there was to be a memoralle revival of that spirit, but things were destined to grow worse before they grew better.

The drift toward arbitrary rule, which dated from the downfall of the Lancast rian line, and so hat 
lasted a century and a half, went far. The doctrine, Growth of the however, of legitimacy and hereditary right Growth of the
doctrine of
jus divinum. grew very gradually. It had become

strong enough even in the first half of the fifteenth century to cause men to feel great compunction on account of the deposition of Richard II, and prepared the way, as we have seen, for the accession of Edward IV, with no title to the throne but birth. During the Tudor period the doctrine became slowly confirmed. When a new line succeeds, with the death of Elizabeth in 1603, we are confronted at once with statements more extreme than ever before, and of evil augury to Anglo-Saxon freedom.

A book called Cowell's "Interpreter" declared that the King is above law by his absolute power; that, Cowell's "In. "notwithstanding his oath, he might alter terpreter." and suspend any particular law that seemeth hurtful to the public estate. . . He is above the law by his absolute power; and though for the better and equal course in making laws he do admit the three estates into Council, yet this in divers learned men's opinions is not of constraint, but of his own benignity, or by reason of the promise made upon oath at the time of his coronation." 1 Convocation,

Subserviency of Convocation and the University of Oxford. the assembled body of the clergy, in 1606, in canons kept carefully secret, declarech, (after denouncing "the fatal error that all civil power, jurisdiction, and authority were first derived from the people and disordered multitude, or either is originally still in them, or else is cleduced by their consent naturally from them and is not

1 Ransome : Rise of Constitutional Government in England, p. 121. Taswell-Langmead, p. 502. 
God's ordinance originally descending from him and depending upon him,") that "sovereignty is the prerogative of birthright," and inculcated in the schools and everywhere passive obedience to the Crown as a religious obligation. The University of Oxford declared before James' death: "It was in no case lawful for subjects to make use of foree against their princes, or to appear offensively or defensively in the field against them "; and James himself, after laying down in "The True Law of a Free Monarchy" the principle that the sovereign was James 1 . responsible only to his own royal will, said: "As it is atheism and blaspheny to dispute what God ean do, so it is presumption and a high eontempt in a subject to dispute what a King ean do, or to say that a King cannot do this and that." 1

The Plantagenets and Tudors were rulers full of masterful qualities. The Stuarts, on the other hand, were quite incompetent to the situation in which they found themselves. The feeling of royal obligation to bring to pass good for their subjeets, weighed upon them but slightly. They were prepared to saterifice the honor and welfare of the country for personal ends. They were never in upright relations with the Church, unfaithful to oaths which they had sworn, relentlessly unforgising, pensisessed of no talent as generals or politiclins. The stuarts, however, evoked a degree of loyilty from their subjects, even from the wisest and nollest among them, such as the Plantigrenets and even the? 'ludors harl never been able to rall out. This wats che to the growth of the doetrine of the divine right.

1 Green: History of the Euglish l'mople, 111, p. i2. 
James I, his son and grandsons, were without doubt heirs of William the Conqueror, indeed, of Saxon Egbert. Whether the nation elected and recognized them or not, after the venerable form, was, according to the new theory, a matter of indifference : by right of birth alone, they claimed, and a great part of their subjects supported them in the claim, that they were Kings of England. Different though they were in character, the Stuarts have this negative trait in common, - a failure to understand and respect the law of the land. Alongside of the constitution there had arisen, through Tudor encroachment, a scheme ready fitted to the hands of monarchs thus disposed. Parliament was the proper law-giving body; but side by side with this legislation stood now a system of royal ordinances, proceeding from the Sovereign alone. Only Parliament could legally grant money, following the ancient right recognized by Edward I and even in Magna Charta, that no man should be taxed unless he were represented in the body that imposed the tax. Now, however, there were customs, orders, fines, "tonnage and poundage," "coat and conduct-money," "ship-money," etc., — various ways by which a King could raise money without recourse to the Houses. Such abuses had been allowed to creep in in times of emergency under the specious pretext that prompt action was sometimes thwarted, if only constitutional ways could be employed. Precedents, however, had been established destined to make great trouble. Most threatening danger of all, by the side of the properly constituted courts, with sheriffs, justices of the peace, and juries, were fixed the courts of Star Chamber 
and High Commission, with inquisition, torture, and summary procedure of every kind. This unconstitutional machinery for ruling the Stuarts proceeded to develop.

Opposition, however, at once appeared on the part of the nation. "The slavish Parliament of Henry VIII, which had become the murmuring opposition of Parliament of Elizabeth, and the mutinous rarliament.

Parliament of James I, became, under Charles I, the rebellious Parliament." 1 At first, feeble and fitful, the opposition gathered force, developing under Charles I into a stern battle between the King and that conservative element of the people who were determined to up-- Charles I and hold the ancient ways. The King was of light. foreed by the Petition of Right, ${ }^{2}$ in 1628 , to admit that his arbitrary course was wrong. It was a profession of the lips, not the heart. $A$ grant of subsidlies having taken place as a consequence of the redress of grievances, Charles dissolved P'arliament, not intending to keep his word, and with the resolve never to smmmon another l'arliament. He was "astamed that lis consins of France and Spain should have completed a work which he had searcely begrun." He commenced in March, 1629, a system of personial rule quite new in England, which continued for eleven rears, during which time the people were not simmoned to Westminster by their delegates. Sover before sine tarl Simon's time harl the voice of the people leoph silenered for sueh an interval: only oncer before lated there been

\footnotetext{
1 Bagehot: Burlish fonstilution, p. 2ks.
}

2 For the full text, see . Ippendix li. 
an interval of half that length. His two main Laud, Straf. agents and advisers were Laud, Archford, and the bishop of Canterbury, and Thomas Went-
policy of "Tholicy of

worth, Earl of Strafford; the two engines through which it was sought to bring to pass the King's will, to the supersession of that of the people, were, for spiritual affairs, the Court of High Commission, for secular affairs that of Star Chamber.

In defiance of the general sentiment of England, the reactionary Laud guided the Church, as the nation felt, perilously near to Romanism. Transubstantiation, auricular confession, preferment of celibate priests, restoration of image worship, adoration of the crucifix, minute attention to vestments, genuflections, vigils, pilgrimages, - these, once discarded, were now revived. At the same time there sat at the King's right hand as Queen, the Catholic Hemrietta of France, daughter of Henry IV, a princess inheriting her father's courage, enterprise, and wit, but drawing from her mother, Maria de' Medici, an Italian dexterity in intrigue, subservience to priestly advisers, and a complete devotion to the Church of Rome.

In secular matters, at the same time, the monarch's hand was carried ever higher and higher. It was no longer a series of isolated, arbitrary acts that the citizen beheld; but Laud and Strafford, pushing ever more strongly, developed the policy known as "Thorough," - a consistent, energetic system of rule going directly against popular liberty, even to the last bulwark, the right of taxation. In all points but one the government of England lad become as despotic as that of France and Spain : as yet the King had at his command no standing army. Should this one obstacle 
block the path? It was resolved that such an army might be, and to meet the eost, recourse was to be had to ship-money. In former ship-money. times, to meet foreign dangers, the Kings had exacted of the Cinque Ports and the maritime comnties the maintaining of ships of war. Acting on these preeedents, Charles now sought to levy a general tax, nominally ship-money, but the yield of which might be applied to any use. With this word, so memorable in the history of English-speaking men, let us turn aside for a while from the tale of the mad race of the Stuarts toward absolutism. Anglo-Saxon freedom was on the point of perishing. Precisely now, in the nick of time, beeame operative in its behalf a force from America, - a force at first scarcely traceable, but destined in time to grow momentons. 


\section{CHAP'TER VIII.}

THE SETTLEMENT OF AMERICA.

$1607-1700$.

Horace WaLPole, an important figure in England in the eighteenth century, when the news of Burgoyne's surrender at Saratoga reached England, wrote to the Countess of Ossory, Deeember 11, 1777: "Well, Marlame, as I told Lord Ossory the other day, I am satisfied. Old England is safe, that is America, - whither the true English retired under Charles I." 1 What reason is there in such a statement as this? Horace Walpole asserts that Ameriea was more English than England herself, the true English having retired to America under Charles I.

Just at the hour when the Tudors were giving place to the Stuarts, two events took place within

Charters of the Last lndiat and Virginia Compa.
uies.

about six years of each other, at the time regarded as having the slightest possible significance, of which however the eonsequences have been of transcendent importance in the listory of the world. These events were the granting of eharters to two commereial companies, the one designing to engage in mereantile operations in the East Indies; the other, looking for its field of operations to the coast of America. The

1 Walpole's Letters. 
first of these charters, granted December 31, 1600, was the foundation of the vast Asiatic empire of England; the second, granted April 10, 1606, the foundation of America. With those eharters began the diffusion of the English language, institutions, and influence beyond the narrow bounds of the little island of Britain to the four quarters of the earth.

In 1607 , a colony with no higher purpose than the establishment of a trading enterprise that might be lucrative, fixed itself at Jamestown in Vir- settlement of ginia. In the heterogeneous company Jamestown. were few or none actuated by any ligh prineiple. A considerable part of those who came in the first years came not of their own free-will, but were deported from England as idlers or, inteed, conviets, of whom the mother-eountry might conveniently in this way rid herself. In the ease of the better elass of settlers, who eame of their own free-will, the motive for emigration was certainly not discontent with the politieal or religions conditions at home. They desired simply to make money, and saw in the fur trate, the mines, the angienlture, which they hoperl to be alle to develop in the new worlil, at better opportunity for gain than was offered to them elsewhere. With no grievance as to either Chureh or State, eonforming without a murmur to what both demanded, they grave their energites to carrying ont selemes of material profit.

Far more interesting in commection with the history of Anglo-saxon freerlom, wats the burly of settlem, who, uncter the new charter, presently ormsuouth. came to ocenpy the comntry farther to the north. 
"Give praise to others, early come or late,

For love and labor on our ship of state.

But this must stand above all fame and zeal:

The Pilgrim Fathers laid the ribs and keel.

On their strong lines we base our social health -

The man - the home - the town - the Commonwealth." 1

At the time when the Jamestown settlers were gaining their foothold, a group of men and women belonging to a sect known as Separatists, dwelling in Lincolnshire, in the east of England, were undergoing persecution. Their station in life was that of yeomen, the lower middle class, below the gentry, but still free-holders, - the class to which belonged the tradesmen of the towns and the small farmers who then abounded throughout the country. To the Separatists a faith simpler and less formal than the prevailing Anglicanism was congenial, and in the effort to cherish such a faith they found the hand of the established Church heavy upon them. Through peril and hardship a small band of them made their way to Holland, where, for a decade, under the ministrations of John Robinson, one of the memorable representatives of the spirit of free thought, a spirit which at this time was beginning to stir in the world, they worshipped God not as the bishops prescribed, but as their own consciences dictated. But Holland was not to their mind, and in 1620 came, at Delfthaven, the famous embarkation, of which the result was the establishment of New England.

As regards the establishment of the Pilgrims at Plymouth, the thing of interest to notice in connec-

1 J. Boyle O'Reilly : Poem at Plymouth, Augnst 1, 1889. 
tion with the present subjeet is that politically they did not reproduce the state of things they had left behind; nor, on the other hand, did they invent something new. In the history of the English-speaking race, the wise Revival in New England of the ancient Anglo-Saxon reformers have been the true eonservatives. True conservatives were the Pilgrim Fathers; for in the society which they set up, they went back to old ways which in England itself had been largely forsaken.

In the earlier part of our study of Anglo-Saxon institutions, we were much concerned with the tunseipe, the fenced village within which submergence dwelt the eommunity of eeorls, - the in England house of the retheling rising among the of the popular moots. humbler homesteards, the huts of laets and theows arjacent, the place for the moot in the centre, beyond the paling or mound the allotments of plough-land and grass-land, and eneireling all, the common waste. The tun-seipe was the unit of political organization; an aggregation of them formed the hundred or wapentake; an aggregation of hundreds in turn formed the shire; the shires combined at last into the kingrlom. As we eome down the centuries, the nane township grathally retires, the term parish taking its platee; a term denoting the sinne thing, but bringing into view the eedesiastical sicle of the organization, whicl, through the zeal of the mediaral rhurehmen, played a large part in the lives of men.' $A$ s early as the thirteenth century the vestry-meding heomes aly atrent, - a tun-most for chureh purposes, in which "resu villeins ean join. Matters seeular som (ome to lx

1 Howard : Introduction to Local Constitutional History of the United States, I, p. 31, etc. 
discussed in the vestry-meetings; the lay attributes predominate more and more. When at last the Stuart day is reached, the parish with its vestry has largely superseded the township with its moot. The vestry-meeting provides fully for matters temporal as well as spiritual, and it is, moreover, to be noticed that it is often beginning to lose its original democratic character. We have seen the boroughs fall into the hands of close corporations ${ }^{1}$ in a similar way the country parishes begin to fall into the hands of select vestries, small knots of men forming close corporations, who establish oligarchies in place of the rule of the people, at the very fountain-head.

While the township was thus changing, the shire, too, was becoming greatly modified. As far back as the reign of Edward III certain statutes prescribe "that there shall be good and lawful men in every county to keep the peace." A few years later, "what sort of persons shall be justices of the peace, and what authority they shall have," are set down, the decree enacting that there "shall be one lord, and with him three or four of the most worthy in the county, with some learned in the law." Here in shadowy outline can be made out the incipient institution, the Court of Quarter Sessions, which in the Stuart time, three hundred years later, had taken from the shire-moot all judicial and administrative character, leaving to it only its elective functions. The lord-lieutenant of the county, who appears in the Tudor day as head of the military organization, was an appointee of the Crown ; so, too, the justices of the Quarter Sessions, who, four times a year, held 
courts for criminal jurisdiction, and provided also for the management of roads, of the poor, and for the assessing and collecting of taxes; such, moreover, the ancient sheriff had become. The shire-moot survived only as the occasion when the free-holders, assembling, voted for coroner, an official of higher dignity than at present; for verderer, a functionary charged with the management of the forests; and, most important of all, for the knight-of-the-shire, who should speak for them in Parliament. This was the local self-government which the first English settlers in America had known. This, however, the New Englanders did not reproduce.

The little company of poor men had signed the compact in the eabin of the ".rayflower," to be mutually bound by laws which all were to have sechods of a voice in framing, hat explored for a lit- Puritan eettetle; then, after setting foot on the lonely England. boulder whieh now seems almost likely to be worn away by the reverent trampling of the multitudes who visit it, harl built their camp-fires at last where sweet water gusherl freely from the bosom of a hill.1 They felt forgotten ly the workl. Doing what was easiest to be lone, following traditions whirh. so to speak, had come down in their blond, they set apart certain land to he held in eommon, a homestead for each man, huilt a fort of timber on the hill elose by, ran their palisale where danger sermed most to threaten, established certain simple mles, and, lo, when all was done, the little settlement was through-

1. Johus Hopkins Historical and Political studies, 2d Series, 15 . The writer adapts here a page or two from a previous momograph of his own. 
out, as to internal constitution and external features, essentially the same as an Anglo-Saxon "tun" or "burh," such as a boat-load of the followers of Hengist or Cerdic might have set up, as they coasted searching for a home along the isle of Thanet, - or further back still, the same essentially as a village of the Weser shore or the Odenwald, set up in the primeval heathen days. ${ }^{1}$ To the settlement, they applied the old name of tun or town.

When, ten years later, Winthrop with his Puritan followers came to settle Boston, they were richer, more numerous, better educated, but it was convenient for them, too, to go back to the old forms. Ship followed ship, almost unnoticed in the old world, where the minds of men were absorbed in the struggle between King and Parliament, which presently burst into war. Twenty-one thousand, at length, sailing toward the beckoning finger of Cape Cod, had found a refuge in Massachusetts Bay. They spread from the coast into the interior, through blazed paths of the forest, led by Indian guides to rich intervales in distant valleys, - clustering about water-falls where fish abounded and where the grain could be ground, or in spots where there seemed a chance for mining. Everywhere appeared the house-lots or village-mark; the plough-land, the meadow, the pasture temporarily allotted; and the undivided common waste. ${ }^{2}$ What determined the size of the towns was always convenience in getting to the Sunday meeting; for to church all

1 Edward A. Freeman : Introduction to American Institutional History, p. 15. Herbert B. Adams : Germanic Origin of New England Towns. Johns Hopkins Historical and Political Studies, 1st Series, I, II.

2 Howard : Local Constitutional History, I, p. 53. 
were obliged to go under penalty of fine or severe punishment. Left to themselves, each group of inhabitants thus bound together about the meeting-house, near which also was generally placed the school, contrived for the regulation of affairs which interested all alike the forms which came most handy, and these were the folk-moot with its accompaniments, The townthe local self-government of Anglo-Saxon meeting. days, revived with a faithfulness of which the colonists themselves were not at all conseious. For twenty years Plymouth had a folk-moot for its entire jurisdietion, open to every freeman. 'The restriction which in the colony of Massachusetts Bay admitted only churchmembers to the franchise, was at last abrogated, so that there, too, every reputable citizen had a right to vote. To east a glance ahead, in a century and a half, Massachusetts, alssorbing P'ymouth and holding possession of Maine, contained more than two hundred towns. In New IIampshire, Rhode Island, and Connectient, the population was similarly apportioned into townships, whose constitution is thus described by a witer of the time: "Every town is an incorporated republic. The selectmen by their own anthority, or upon the application of a certain number of townsmen, issue a warrant for the ralling of a townmeeting. 'The warant mentions the business to be engaged in, and no other an be lecrally executed. The inhabitants are waned to attend ; and thry that are present, thomgh not a gualeter or tonth of the whole. have a right to procered. They choose a president by the name of Moderator, who resulates the proceedings of the meeting. Eatrh individual hats an equal liberty of delivering his opinion. anel is not 
liable to be silenced or browbeaten by a richer or greater townsman than himself. Every freeman or free-holder gives his vote or not, and for or against, as he pleases; and each vote weighs equally, whether that of the highest or lowest inhabitant. . . . All the New England towns are on the same plan in general." " "A New England town-meeting," says Freeman, "is essentially the same as the folk-moot." 2

Of the forms of organization above the town, the hundred was never reproduced in New England at all, while the shire or county, though reproduced, never acquired the importance which it had in the mother-land. At first the towns sufficed; the counties did not appear in Massachusetts Bay until 1643, while elsewhere there was still longer delay, Rhode Island first adopting shires in 1703. They had little significance, except as judicial districts, the courts being modelled after the English Quarter Sessions. The venerable shire-moot, still persisting in England as the centre of political life, the assembly at which were elected the representative knights and certain local officials, though most of its judicial and administrative functions had long been lost, never appeared in New England.

What was the course of development in Virginia, the great colony which presently grew ont of the

Reproduction in Virginia of contemporary England. little settlement at Jamestown, becoming the representative colony of the South as Massachusetts soon became that of the

1 Gordon: History of Independence of United States, I, p. 262.

2 American Institutional History, Johns Hopkins Historical and Political Series, I, 1, p. 16. 
North? As Virginia took shape, her institutions were no less thoroughly English than those of Massaehusetts, and yet they were not the same as those of Massachusetts. While in the ease of New England the settlers reverted to a state of things so primitive, Virginia, on the other hand, reproduced the forms which actually existed at home contemporaneously with her settlement.' First, we find as early as 1631 the name parish; the earlier The parish. "plantations" had no doubt been de facto parishes, and afterward the counties were regularly subdivided into them. Here, as at home, the restry had chief authority, composed usually of twelve "of the most sufficient and selected men," who soon became, after the home precedent, a elose corporation for the discharge of funetions both ecclesiastical and civil. Here the clergyman presided as first in dignity (another English praetice), whose salary was yearly sixteen thousand pounds of tobaceo. On the whole, the Virginia vestries, though aristoeratic in form, were fairly wise and moderate, and usually sustained by the people. though the people had no voice in choosing them. So great a democrat as Jefferson testifies in their faror: in arly diys when the roval governor tried to foree "lpon the parishes his own nominees, an aetive resistance was made, and in the bickering back and forth the way was prepared for the events of $1776 .^{2}$

But though the parish performed many important functions, it was early overshadowed ly the county, which possessed all the highor

The county.

1.E. A. Freeman: American Instilulional History, Johus Itopkins University Studies, 1st Series, 1, p. 17.

2 Howard: Local Constitutional Goverument of the United States, I, p. 118 , etc. 
offices of local self-government and was as well the unit of representation and administration. This, too, was a reproduction of a contemporary English organization. Though the first settlers had adopted the village community, economic causes brought it about that the later organization was soon adopted; for everything tended to plantation rather than town life. As early as 1634, eight shires appear, "governed as the shires in England," which become seventy-four by the time of the American Revolution. The Courts

The Court of Quarter Sessions. of Quarter Sessions appear duly in all these, composed of justices appointed by the royal governor. The board of justices in each shire has the privilege of nominating to the governor the appointees; and it therefore results that the county court, like the parish vestry, becomes a close corporation composed of the leading gentry. ${ }^{1}$ The justices assume all functions, judicial and administrative. The only approach to a democratic feature in the aristocratic polity is the manner of electing the burgesses, the members who sit in the colonial assembly, and who constitute with a royal council nominated by the Crown, and a Crown-appointed governor possessed of a veto power, the central government. As the colony becomes established, two burgesses sit for each county, and these are chosen by such freeholders as have an estate for life in one hundred acres of uninhabited land, or in twenty-five acres with a house on it, or in a house or lot in some town. With so high a property qualification, very many were disfranchised, but we may discern here a county court. feature in some measure popular. The

1 Howard: Local Constitutional Government of the U. S., I, p. 388, etc. 
elections took place in presence of the sheriff (who was either himself a justice or an appointee of the justices), at the county court, the people coming together in shire-moot, for the purpose, after the fashion not yet obsolete in England. Crippled though the power of the people was, still the Virginian court-day in the old time must have presented a demoeratic aspect. It was a holiday for the whole country-side, especially in the fall and spring. The people came generally on horseback, on foot, in wagons. In the great assembly on the court-house green, hunters, small farmers, great proprietor's, grinning negroes, mingled freely together. Old debts were settled, new debts contracted; the auctioneer and the peddler plied busily their vocations. If an eleetion was pending, every convenient stump pedestalled its orator. In a measure, the county court took the place of the town-meeting: like the town-meeting it exercised a powerful levelling influence, and was in a way, by no means ineffective, a training-school for the republican life which lay in the future. ${ }^{1}$

That New England and Virginia should have ardopted institutions so widely different is quite explicable. New England, while eontaining a Reasons for few families of gentle blood, was in vast the contrast majority settled by yeomen, the lower micl- Englanu and dite

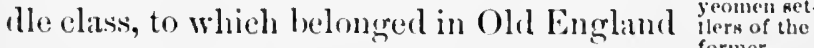
the traders and small farmers. It was in former. this elass that the Anglo-Saxon strain ran purest, with least of Norman intermixture. 'To sueh men, primitive ways were most likely' to be eongenial; to such

1 Hannis Taylor: Origin and frowth of English Constitution, I, 39. 
men, also, primitive ways were most likely to be familiar. The public life, which these humble people knew for the most part, was that of the small neighborhoods where the tun-moot was not as yet quite dead; for it was precisely here that ancient usages clung most tenaciously. "The smaller and more decidedly differentiated the institution, the less the liability to change, modification, or substitution." 1 When left to themselves, it was natural that, following tendencies which had come down in their blood, they should adopt and at the same time strengthen what remained of the ancient features of AngloSaxon freedom. It was presently found that what nature suggested in the way of forms of polity was admirably fitted for the life into which the circumstances of their new home forced the colonists. Hence, it is easy to understand why the resuscitated government by popular moot came soon to manifest the greatest vigor.

In Virginia, on the other hand, the yeoman element was small. At the top of society was an aristocracy The great planters of of rich proprietors holding large estates, Virginia. allied through similarity of condition, and through ties of blood also, with the landed gentry of the mother-country. The law of primogeniture being rigidly maintained, each great estate, consisting often of thousands of acres, descended in each generation to the eldest son, his brothers and sisters being slightly portioned, if at all. There were, indeed, small farmers, a class springing in part from unportioned younger sons, in part from later immigrants, who were at a disadvantage as to

1 Phelan: History of Tennessee, p. 203. 
getting hold of the soil: this class, however, was unimportant as compared with the landed magnates, with whom lay all social prestige and, for the most part, political power. The particular form into which society in Virginia arranged itself, was much affected by the special industry to which The slaves. the colony became almost exclusively devoted, the raising of tobacco. On the great estates the laborious process of producing the invariable crop could be most conveniently left to the hands of negroes. Everything favored the development of slavery, and slaves soon came to make up nearly half of the population. In a condition not very different from that of the slaves were the indentured white servants. These were penniless immigrants, sometimes English convicts or patupers, shipped to the New World and bound out for a term of years by the whites.

government; sometimes people of more respectable antecedents, who in return for their passage-money freely gave themselves into practical serfdom. In these eircumstances, liblor necessarily fell into disrepute: a class of poor whites arose, l)isrepute of descendants of those so unfortunately placed as to be mable to obtain land or of those who lacked energy to do so, who squatted on the plintations in out-ofthe-way swamps or woods, pushed into the wilderness as hunters and traplers, of tramped as roving vagalomds from estate to estate. Such town-life as that of New Eingland would, of course, in a society so sitmated, be inpussible. The pirtish womld necessinty be a fechle sulstitute for it. The inhalbitants were seattered throughout the vast eounties with un rallying-points but the manor-honse of the plinters. Of 
manufacturing of any kind there was no trace, and the class of honorable merchants was almost unknown. It was indispensable to each great plantation that it should be accessible from the sea, a condition easily supplied through the magnificent streams which afforded paths everywhere into the interior from the Chesapeake. Each planter had his own wharf and warehouse, to which his negroes brought yearly at harvest the great tobacco-yield, while English or Yankee ships, freighted with foreign manufactures to be given in exchange, lay ready to receive it.

The typical Virginian, as the colony developed, was devoted to the English King and Church. If he possessed overweening family pride, extravagance, and contempt for work, he had also the splendid Virtues of the virtues of a cavalier class, - generosity, Virginia so- bravery, and lrospitality. Even the poor
ciety. whites, forlorn as they were for all purposes of peaceful, well-ordered society, possessed qualities which fitted them admirably to be frontiersmen and soldiers. Many a planter could claim descent from historic stock; and sometimes, as in the case of the old Lord Fairfax, who established for himself a broad sylvan domain in the valley of the Shenandoah, and lived there like the banished Duke of "As You Like It," in the "Forest of Arden," the blood of the Virginians was of the noblest.

Since, then, the isolation of the great estates at the South made it out of the question for the men to come together as in the compact communities of the North, and since, moreover, the more heterogeneous character of society in the former case interfered with the disposition to come together, - instead of a 
State made up of small democratic communities, within each one of which the men, gathered in town-meeting, governed themselves, a State came to pass, the people of which had little opportunity or desire for the general discussion of public measures. Care for political matters was, in the mass of men, very slight, from the fact that a class small in number almost monopolized property and power. The territorial magnates were all-in-all. In the House of Burgesses spirit of the at Williamsburg, the great planters came Burgesses. together, and few besides. Among them, indeed, political interest was keen enough. Each had a great stake in the country; each was accustomed to power and fond of wielding it. In this aristocratic legislature the energy was marked, and the spirit of freelom very manifest. The royal governors found the body often intractable; constant bickering prevailed between them and the assembly, through which the latter learned the habit of calling into question the authority of the King, and also came to love an atmosphere of strife.

There was not only no proper popular moot in Virgrinia, lut in the eolonies of the South and Southwest grenerally, as they became gradually established, it did not aprear. As a definite polity shaped itself, there were in the case of each one peculiarities of eonstitntion, but into these we do not need to enter. In South (andina, the parish possessed a somewhat vigorous life: in Maryland, moler the feulal sway combition of of the propriotary arovernment of Lord bial- Soutlecaro. timore, the manners of medliabial times to latul. some extent alpeared: in general, however, Virginia was the type of all. 
If we glance at the middle colonies, in New York the Dutch were long enough in possession to stamp Feudaliem in upon the settlement an impress not at all New York
and Pennsyl. democratic. Along the Hudson the pavania.

troons, on their estates fronting sixteen miles on the river and running back indefinitely, had set up a feudalism as marked as that of the seigneuries which the French at the same time established on the St. Lawrence. On Long Island and the shore near by, there were self-governing towns quite similar to the Connecticut Communities close at hand. ${ }^{1}$ After the English occupation of the colony in 1664, an organization of counties with subdivisions of townships gradually makes its way, which, in our own century, has come to play an important part. Here, though the town-life is faintly marked, possessing with less distinctness than in New England the moot, yet certain functionaries exist, freely elected by the people, the most important of whom is the supervisor; the town supervisors, forming in each shire a board sitting together at stated times, provide for the most part for local self-government. This is the germ of the Township-connty system, which, as will hereafter be seen, has been very important in the settlement of the West. ${ }^{2}$ In Pennsylvania, though the great proprietor, Penn, was practically a viceroy beneath an English suzerainty, exercising over a population containing many elements besides English, a rule which was far from favorable to democracy, yet at one point occurred an interesting development.

1 Johns Hopkins University Studies, 1st Series, VI, VII, and XII. Howard : Local Constitutional Government of the United States, I, 114, etc.

2 Howard, I, p. 102, etc. 
While the town was insignifieant, the eounty appeared with great prominence. It was the unit of representation, within whieh assemblies highly democratic convened for the election of officers. These assemblies were, indeed, a revival of the shire-moots in form more complete than is to be found anywhere on Anglo-Saxon soil since the days of the Heptarchy. Next to the Township-eounty system of New York, the County system of Pennsylvania, after the ordinance of 1787 had finally thrown open to settlement the immense central region of America, determined the present form of local government throughout the great Northwest. ${ }^{1}$

So it was that the Anglo-Saxon in the seventeenth eentury established himself in a new home beyond the sea, bringing with him Anglo-Saxon freedom; just as in the fifth eentury he had established himself in England, bringing with him that same freedom from the marks, hundreds, and tribes of the plains of the Elbe and Weser. As that ancient freedom was transferred across the wider ocean, it was by no means unmodified. The proper primordial cell of any Anglo-Saxon body politie is the popular moot, the assembly of the sovereign eitizens for the exereise of govermment of the people, The popular by the people, and for the people. Onr mordlal cell of

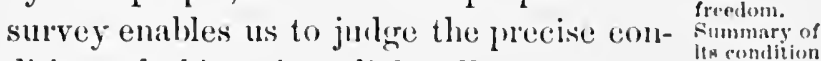
dition of this primordial cell among the in incondition Englishmen of the Thirteen Colonies. It existed in the somulest and best-rleveloperl form in the New England town-meeting. In the New

1 Howard: Local Constitutional Goverument in the United States, p. 383. 
England general courts, each deputy, in nowise superior to those who sent lim in wealth or position, stood for the little democracy he represented, as the humble reeve with his four associates had for ages stood in the general eourt for the tithing in which he dwelt. He was not his own master, except in so far as his superior ability or charaeter made his townsmen give way to him. He was earefully instructed what eourse he must pursue; was liable to censure if he went against the wishes of his sharply watching constituents; and each year must submit himself anew to the suffrages of his townsmen, who promptly consigned him to private life if his course were disapproved. While the deputy was thus closely watched, the town-meeting took care to delegate just as little authority as possible. It reserved to itself all business exeept what it must perforce put out of its hands, every freeman who sat in the town-hall before the moderator feeling forever upon his shoulders the strain, so salutary and so strengthening, of the public burden. Though in the Thirteen Colonies towns play little part except in New England, it would be wrong to conelude that, for that reason, the primordial cell in the body politie was elsewhere wanting. Everywhere we ean find the county, and at the heart of the county is the county court. It was largely a reproduction of the English Quarter Sessions, to be sure, with justices appointed from above, not eleeted from below; but as side by side with the Quarter Sessions, since its establishment in the time of Edward III, the shire-moot had gone on, retaining its ancient functions as an elective body; 
so we can find in America, sometimes, indeed, in a form very shadowy, but sometimes in a form very distinct, the assembly of the people to confer and to speak their own will. It appears vaguely in Virginia, where we have seen a portion of the people cast their votes on county-court day, in the presence of the sheriff, for the burgesses who are to sit at Williamsburg. It appears very definitely in Pennsylvania. Nowhere, probably, was the popular moot utterly unapparent, though in many places no doulst it was greatly attenuated. We shall note hereafter to what extent it has been possible to revive it, and what are its prospects for the future. 


\section{CHAPTER IX.}

\section{THE ENGLAND OF CHARLES I.}

Charles I, 1625.

Havivg seen an English-speaking world firmly established in the Western Hemisphere, let us now return to England to watch the fortunes of the stock in the old home. As has been described, an utter subversion of the ancient popular freedom seemed on the point of taking place at the time of the accession of the Stuarts. Under James I, the claims of absolutism, before his time only vaguely set forth, were carefully formulated and published. These claims, Charles I went to work with great energy to make good. At the beginning of 1640 , when Charles had

\section{Effort of} been ruling for eleven years without a Charles to
rule without a Parliament. locked in a fierce wrestle; for the people, roused from an apathy that had lasted since the fall of the Lancastrians, nearly two hundred years before, had been stung into vigorous opposition by the encroachments of tyrannical princes utterly without tact. Charles, at war with the Scotch, upon whom he had undertaken to force a form of worship to the last degree repugnant to them, found his resources 
quite inadequate to the situation, even though the judges had sanctioned ship-money, and was forced at last to summon Parliament in hope of a subsidy. The members of this Parliament, the "Short Parliament," took their places upon the benches The Short of Westminster, so long empty, quite Parliament. strange to legislative work. In the long intermission, the longest which had oceurred since Parliament began, even methods of procedure had been to a large extent forgotten. There were a few veterans, however, who had fought on the floor of St. Stephen's in the days of Sir John Eliot and the Petition of Right, and these served as instructors. Particularly conspicuous in this capacity were Pym and Hampden. Both Houses were apt pupils. As to what was the right course, neither Lords nor Commons had any doubt; and before three weeks had passed, the ling, disheartened at the stern demand for a redress of grievances before a grant of money should be made, put an end to the session. Necessity, however, pressed. His ill-appointerl, demoralized forces fled before the Seoteh at the skirmish of Newburn, in the summer. No other issue being possible, the writs were issued again, and in November. 1640, convened that memorable Parliament, whose history was not to end until nearly twenty years had passed, - the "Long Parliament."

Parllament.

The temper of the Long Parliament was most stubhorn, and it showed from the first the soundest linglish courage in earrying out its purpose. liefore the King could have help from the nation, a number of innovations nom time-honored constitutional ways must eome to an end, and a swarm of evil andvisers 
must be dismissed and brought to judgment. As yet, Attempts to Attempts to there was no whisper of any polity except
restore equi. librium be tween King, flo in England in tween King, feudal times, - in which the people were Commons. that which had come up in England in by no means sovereign as in the AngloSaxon freedom, but stood co-ordinate with the King, and a privileged class, - possessing a voice in the government, but far from being supreme ; in this system, the balance had been disturbed by the effort of the monarch to arrogate all substantial power to himself. Both Houses were equally zealous to restore the ancient equilibrium, lost since the Wars of the Roses. Both Houses were firm in declaring that England must be for Englishmen; foreign money, foreign armies, must play no part in English affairs; above all, the terrible potentate, whose yoke had been thrown off a hundred years before, but who sat forever sleepless upon the distant Seven Hills, was a personage abhorrent.

At once after the assembling, Laud and Strafford, the leaders of the King's administration, the chief Arrest of Laud and directors of the courts of High Commission Strafford. and Star Chamber, were taken from the right hand of Charles and thrown into dungeons; while frowns so sinister were bent upon Henrietta, the Catholic Queen, that fears were entertained of her being torn to pieces in the street. Strafford atoned at the block for his effort to play in England the part of a Richelieu; his allies in promoting an arbitrary policy, fled for the most part beyond the sea; Laud, in the Tower, awaited the axe, while the ecclesiasticism of which he had been the type and spokesman was proscribed. 
Charles for the time showed prudence: he won friends among the Scoteh Covenanters by pretending a spirit of concession; he bent before the storm of reform which raged in his southern kinglom; he appeared on the point of gaining the advantage, for to many in the nation the fierce rush of Parlimment toward a new order began to seem extreme and dangerous. The Grand Remonstrance of November, 1641,1 when the long Parliament (which had The Grand extorted from the King authority to sit as long as it should think proper) was just a year old, was a sharp arraignment of the King for his arbitrary policy. It was received with small favor, being earried in Parliament by a bare majority against an opposition so violent that a bloody battle seemed on the point of taking place within the walls of St. Stephen's itself. A reaction had set in which a emming despot might have used to make his position secure. Fortunately Charles was as stupid as he was stubborn. $13 \mathrm{y}$ violating the most cherished privileges of Parliament in his attempt in Jammy, 1642, to seize within the House of Commons the Five Members, he confirmed in the minds of the people the worst eharges that had been lyought as to

Attempt to arrent the five Members. his disposition and purpose, and checked to a large extent the outflow of sympathy which his situation was beginning to evole. To a linge extent, but not entirely ; for multitules, both of high and low degree, who in the time of the demand of ship-money had been glad of the resistance of llamplen. and who more reeently had rejoiced when the ushore of the

1 See "Constitutional Dowments of the Puritan Revulution, selected and edited by S. R. Gardiner," Clarendon 1'ress, 15s!?, 1) 1:27. 
black rod committed Strafford to the Tower, had begun to think that the course of reform was quite too fast and too far, that the King had been disciplined enough, and that a good result for the country would be sooner reached ly standing for the Sovereign than by standing for the Houses.

Only war was possible. On the side of the King were arrayed most of the nobles and gentry and Constitution of the two the vast number of those in a humble staparties.

tion who were especially dependent upon them. Here, also, stood the universities and most of those possessing a refined culture. As to religions faith, Catholies and Anglicans were adherents of the royal cause. The strength of the Houses, on the other hand, lay in the "plain people." In this class must be comprehended, first, the traders and artisans of the towns, especially of London ; and, second, the small landed proprietors in the country, the yeomanry. For more than a century, this sturdy body of the people had been diminishing in numbers, and its decline had been lamented by great men. "My father," said Hugh Latimer, in the first half of the sixteenth century, "was a yeoman, and had no lands of his own; only he had a farm at a rent of three or four pounds by the year at the uttermost, and thereon he tilled so much as kept half a dozen men. He had a walk for a hundred sheep, and my mother milked thirty kine; he was able and did find the King a harness, with himself and his horse, when he came to the place that he should receive the King's wages. I can remember that I buckled his harness when he went to Blackheath field. He kept me to school; he married my sisters for five pounds apiece, 
so that he brought them up in godliness and fear of God. He kept hospitality for his neighbors, and some alms he gave to the poor. And all this he did of the same farm, where he that now hath it payeth sixteen pounds rent or more by the year, and is not able to do anything for his Prince, for himself, nor for his ehildren, nor to give a cup of drink to the poor."

Sir Thomas More, too, referring to the straits into which the small farmers were brought by the alvancement of rent in Tudor days, declares: "In this way it comes to pass that these poor wretehes, men, women, husbands, orphans, widows, parents with little children, householders greater in number thin in wealth, all of these emigrate from their native fields, without knowing where to go."

To these complaints may be added those of Roger Ascham and Lorl Bacon, at a time a little later. "And so from the stuff of the Latimers, from the sturdy spirit that amid the flames of the Oxford stake cried, 'Play the man, Master Ridley' and the mingled strength and sweetness that neither prosperity could taint, nor the executioner abash, were evolved thieves and vagrants, the mass of eriminality and pauperism that still blights the innermost petals and preys, a gnawing worm, at the root of England's rose." 1

The disappearance at a later time of the yeomany. the Finglish patriot to-dity monrus over as the greatest calamity which has lefallen his comitry. In the seventeenth century. however, the youmen were still numerous, for fully one humdred and sixty thomsind

1 Henry George: : Progress and Poverty, pl. 210, 211. 
small farmers could be counted. From these, with a considerable infusion from the craftsmen of the cities, their close brothers, proceeded in the course of the next few years, under the guidance of a matchless leader of men, the most extraordinary soldiers whom the world has ever seen, - of courage most unflinching, of aim the highest, strictly submissive to the severest discipline, and yet putting brain and soul into their fighting to a degree not equalled before or since.

In religion, the party of the Parliament comprised all such as had lived in more or less definite nonconformity to the English Church except the Catholics; in a word, the Puritans. No sharp line, indeed, can be drawn between the partisans of King and Parliament. There were traders and farmers who fought for Charles, side by side with the nobles and gentry and their retainers : the King's strength, however, did not lie with them. Just so for the Parliament, strove here and there high-born men of long descent and great estates; but from the outbreak of war the number was small, and as the struggle proceeded it grew smaller, until the plain people at last stood almost by themselves.

In the excited nation, the tumult of argument between neighbor and neighbor swelled into a roar of Outbreak of outcries of recrimination, out of which rose war.

at last, in 1642, the lond clash of arms. As yet, there was no advance beyond the principles of 1640, among the Parliamentarians. "King Pym" ruled at Westminster with authority derived only from an extraordinary personality; but none the less real on that account. Hampden, though not in chief 
command in the army, yet at the head of the noble Buckinghamshire regiment, the most popular man in England, infused his spirit into those who had taken the field. Both Pym and Hamplen would have shrunk utterly from popular government as we know it; for they saw nothing better for England than a monareh, restricted, but still possessing power in his own right, - nobles, under limitations, but still possessing high privileges, - a people, not voieeless in affairs of state, but by no means sovereign, by no means the factor in the state through and for which all things should be and be done. From the brow of Edgehill, Charles, one elear Edgehill. Octoler day, sweeping with his eye the broad landseape, which extended from the hills of the western shires, for the most part faithful to him, to the long levels of the eastern counties, where lay the rebel strength, beheld in the direction of Warwick the advaneing army of his foes. Presently on the plain below, Prince Rupert for the first time in piteher battle, with picturespue, mad energy, shook the roins over the neck of his war-horse ; the Romndlead foot standing meantime with the steadfastness that was to bring to patsis in the and memomable results. There

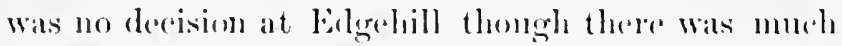
bloodshed, hut in the months that followed the sale inclined in faros of the King. "The rear 16te, a gloomy one for the Homses, drew forwand with elefoat and loss. Pyn diefl worn ont at his post at st. Stephens: Ilamplen fell at ('halghove Fireld.

But a change for the better towk plater. While

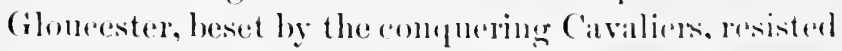
with a courage that secuned only lesperate and futile, 
young Sir Henry Vane, upon whom had fallen the mantle of Pym, saved the all but hopeless cause of the Houses by negotiating with the Scots the Solemn League and Covenant, ${ }^{1}$ bringing thereby

Solemn

League and Covenant and Marston

Moor. to his disheartened party the friendship of an energetic nation, - a friendship at once made tangible through a reinforcement of twenty thousand hardy troops. The pikes of the London train-bands found the joints of the Cavalier armor on the field of Newbury. A few months more and the hard rider, Rupert, was himself overridden upon Marston Moor. Standing amid the wreck on that terrible field, thinking of the panoply of proof which the swords of his troopers had not been able to shiver, and of the stout hearts which the panoply covered, he administered a noteworthy baptism, so that in Rupert's phrase those invincible squadrons and their leader stand in history as Ironsides.

Marston Moor was for Charles the beginning of the end. The Self-Denying Ordinance ${ }^{2}$ shelved for the Parliament the incapable generals; the New Model reorganized and concentrated the army. On the Broad Battle of Moor by Naseby, the King, outnumbered, Naseby. dashed with all the valor in the world upon the line of his foes. Rupert sought to wash out the disgrace of his defeat before York in the blood of the Parliamentary left; but as he galloped too fast and too far, Cromwell with the Ironsides trampled out Sir Marmaduke Langdale, and Fairfax snatched the colors from their dying bearer at the King's centre. When, under the hot noon of that June day, the

1 Gardiner : Documents of the Puritan Revolution, p 187.

2 Ibid., p. 205. 
roads northward to Leicester beeame the theatre of panic-struck flight and implacable pursuit, all was over for the cause of Charles: heneeforth he could only "flit like a wounded partridge," from castle to eastle, among his friends still faithful, till at last, at Newark, he gave himself into the hands of his enemies. Though beaten in the field, and in the power' of his foes, he was not yet hopeless. Among the victors discord had arisen. The Independents ${ }^{1}$ had gradually acquired great influence, who, rejecting the authority of both bishop and synod, demanded toleration for all shades of religions belief, - a principle which filled the Presbyterians, heretofore mainly powerful in Parliament, with no less horror than the Popery and Prelaey whieh they had been so sternly confronting. Charles imagined he might procure by intrigue what he could not win by arms. He paltered in a clouble sense, now with one party, now with the other, reserving in his treacherous heart the right to withdraw any promise he might make, to falsify any work he might utter, to betray any agent he might see fit to use, if he might therely further his scheme, to rule without restraint. For a time he alpeared likely to sucreed. Ilis foes were a household utterly at variance among themselves. 'To the eye of the world, the great army leaders, ('romwell, Farfir. Ireton, secmed to have Iost all derision, if not to have beome quite finthless to the catuse for which they hat fonght. In the whole history of human liberty these has loon no more perilous crisis

1 For the effect of an inthence from America ujon the rise of the Independents, see the writer's "I Ife of Yomm Sir Henry Vane," p. libt, ele. 
than that which had now eome about. Through whom was the danger averted, and what means were used in the work of saving? In the story of AngloSaxon freedom, no moment is more interesting than that which we have reached; there are no heroes whom the lovers of that freedom should hold higher, than those who now eame forward. They were none other

The rank and file of the Ironsides. than the common soldiers, the rank and file of those extraordinary Ironsides, who, as we know, were nothing more nor less than the "plain people" in arms. They were tradesmen and artisans of the towns, who, in the stress of the trying time, had laid aside yard-stick, hammer, and plane; above all, they were the strong yeomen, the stock that had furnished archers and spearmen to the great Edwards and Henrys, the stock from which came the faithful ceorls who died with Saxon Harold in defence of the raven standard at Hastings. Out from them had just gone the settlers of New England. It was these yeomen, who, like their ancestors, forsaking in a trying time plough and seythe for blade and corselet (with what effect has been narrated), now while the great men hesitated, interfered that the fruits of their victories might be secured. Forsaking the original ground of their party, that King, Lords, and Commons should be in equipoise, the rank and file of the Ironsides now put forth a plea for that earlier polity, the polity of their ancestors on the Weser plains, which, transferred to Britain, had been fought for beneath the hill where gleams even to-day the white horse, - the polity renovated by Alfred, overwhelmed by the Normans, government of the people, by the people, and for the people. 
In Oetober, 1647, the army, fearing that their effort for a freer England was to be in vain, had mutinied. The mutiny had been promptly sulsdned, but the spirit out of whieh it festoes. grew wis destined to prevail for a time. The mutineers had worn in their hats a paper which had been drawn up and printed among the Agitators, the lower couneil of the Army. It was ealled the Agreement of the People; at this, and at another manifesto of the Army, The Case of the Whole Army, it is now time for us to east a glanee. It was not unnatural, perhaps, that seeing their generals on intimate terms with the King, who lived in splendor while the world did homage to him, the soldiers should suspect them of lnkewarmness, or indeed treachery, as regarded things the soldiers felt to be essential. This they express, and at the same time they declare to their general as follows:-

"We presume that your Exeelleney will not think it strange, or judge us disobedient or refractory, that we should state the case of the Army, how declined from its first prineiples of safotr. what miscliefs are threatened thereby, and what remedies are suitalle. Fir, sir, should you, yea, should the whole Parliament or lingerdom exempt us from this service, or should command our silence and forbearance, pot eould not they nor your dischatrgen us of our duty to Genl, or to our own natures. . . . If our dury bind us when we see our neighlwors homses on time.

1 The citations which follow have been previonsly usel in the writur's

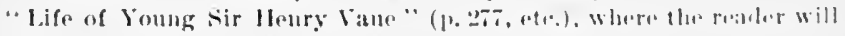
find the action of the Army and the Rumb liarliament Hun fully detailed, 
to waive all forms, ceremonies, or compliments forthwith (not waiting for order or leave) to attempt the quenching thereof, without farther scruple as thereunto called of God, . . . then much more are we obliged and called, when we behold the great mansion-house of the Commonwealth, and of this Army, on fire, all ready to be devoured with slavery, confusion, and ruin, and their national native freedom (the price of our treasure and blood) wrested out of their hands, as at this present appeareth to our best understanding," etc. ${ }^{1}$ This letter was dated at Hempstead, October 15, 1647, and signed by the Agitators, for the regiments of horse of Cromwell, Ireton, Fleetwood, Rich, and Whalley, the core of the Ironsides. Though prolix, it contains no cant or superstition. Is there not, indeed, much beauty and pathos here? And now let us see what is recommended in a paper of proposals received in Parliament, November 1, from the Army.

"Having by our late labors and hazards made it appear to the world at how high a rate we value our just freedom; and God having so far owned our cause as to deliver the enemies thereof into our hands, we do now hold ourselves bound in mutual duty to each other, to take the best care we can for the future, to avoid both the danger of returning into a slavish condition, and the changeable remedy of another war. ... That hereafter our Representatives [Parliaments] be neither left to an uncertainty for the time, nor made useless to the ends for which they were intended, we declare, I. That the people of

1 From the letter to Fairfax accompanying "The Case of the Whole Army." Rushworth : Historical Collections, VII, p. 846, etc. 
England being at this day very unequally distributed by counties, cities, and boroughs, for elections of their deputies in Parliament, ought to be more indifferently [impartially] proportioned, according to the number of inhabitants." The clause goes on to demand the arrangement of this before the end of the present Parliament, which, in the $2 \mathrm{~d}$ article, the soldiers request may take place in September, 1648, to prevent the inconvenience arising from the long continuance of the same persons in authority. After providing in the $3 d$ article that Parliament shall be chosen biennially, every second March, we find in article 4, a most significant declaration: "That the power of this and all future Representatives [Parliaments] of this nation is inferior only to theirs who chuse them, and extends, without the consent of any other person or persons, to the enacting, altering, and repealing of laws, to appointments of all kinds, to making war and penee, to treating with foreign states," etc.; with the following limitations, however: "I. That matter of religion, and the ways of God's worship, are not at all intrusted by us to any human power, because therein we eamnot admit or exeed a tittle of what our consejences dietate to he the mind of God, without wilful sin: nevertheless, the public way of instrueting the nation, so it he not compulsive, is refered to thail discretion." Other limititions are, that there shall be no impressing of men for service; that after the present l'arliament no one is to be questionod for anything said or done in the late disturbantes: that laws are to affeet all alike, and to be equnal and groud. " These things we derlitre to be our native rightst," the document conchules, and 
we are compelled to maintain them, " not only by the example of our ancestors, whose blood was often spent in vain for the recovery of their freedoms, suffering themselves through fraudulent accommodations to be still deluded of the fruit of their victory, but also by our own woeful experience, who, having long expected and dearly earned the establishment of those certain rules of government, are yet made to depend for the settlement of our peace and freedom, upon him that intended our bondage and brought a cruel war upon us."

This manifesto was signed by nine regiments of horse and seven of foot. Had Roger Williams and Samuel Adams put their heads together, could the outcome have been better? "The power of this and all future Parliaments of this nation is inferior only to theirs who chuse them, and extends, without the consent of any other person or persons, to the enacting, altering, and repealing of laws, to appointments of all kinds, to making war and peace, to treating with foreign states," no exception to be made but in the matter of religion, - that to be intrusted to no human power, but each man to choose as his conscience may dictate.

Who the man was who formulated so finely these utterances, no one can say. They came from the rank and file: under some one of those steel headpieces worked the brain that outlined this noble polity, in which there was no place for King, Lord, or Prelate, because the People was to be Sovereign. The leaders felt uneasy. Cromwell could not yet go so far; Ireton now rejected it with indignation. ${ }^{1}$

1 Godwin: History of the Commonwealth, II, p. 451. 
At a meeting convened in November to establish harmony between chiefs and soldiers, when the latter rejected a statement in whieh the name and essential prerogatives of a

Reluctance of the leaders to subscribe.

King were provided for, Ireton abruptly departed, declaring that such a matter must not be touched upon. Vane, too, no doubt at this time was appalled at such extreme ideas. Both Court, Presbytery, and Prelacy were hateful, but Royalty and an Upper House seemed too potent and deeply rooted to be disturbed. How untried and ehimerical the scheme of a repul)lic, in which all precedents were to be disregarded and tradition to be sacrificed! From whom, too, did the ideas emanate? from men of no social importance, from Levellers, fanatical, haughtily insubordinate, discountenanced by every class in society hitherto held to be respectable!

But at such times men think quiekly. The leaders took the ideas of the rank and file, and before the year ended the chiefs and the soldiers were one. December 22 , the shortest dity of the dark English winter, a publie reeon-

The prayermeeting of the Ironsides. ciliation took place anid fasting and prayer. Together they sought the lord from nine in the morning until seven at nightit. Cromwell and Ireton among others praying fervently and pathetioally. The assembly came forth hand in hand, and the eondition of union was that Charles Stulut, that man of hlood, should be called to account. ${ }^{1}$

1 Guizot: llisıory of English Revolulion, p. 3iti, Americatu ed. : also Life of Young Sir Heury Vane, p]. 281, 2\$2. 


\section{CHAPTER X.}

\section{THE ENGLISH COMMONWEALTH.}

Commonwealth, 1649.

Ollver Cromwell, Protector, 1653.

Richard Cromwell, Protector, 1658.

During the year 1648, a struggle took place in England in which the Ironsides won a victory against Ciril war of tremendous odds. The King, in the hands 1648. of his captors, seeking to draw advantage from the distractions which prevailed among them, at last leagued himself secretly with the Presbyterians of Scotland, promising them indulgence for their form of worship and an extirpation of the party of tolerance, if by their help he could come again to the enjoyment of his own. The warfare which followed was more desperate than that of the earlier civil war. The King was not in the field, and the disposition to spare was far less. To the Scotch, the English Presbyterians joined themselves in multitudes, men who till now had fought stubbornly for the Houses; while the old Cavaliers, whether Catholic or Anglican, rode forth again in actual combat, or with sword on thigh only waited for a favorable moment. But the Independents, now thoroughly united, were without fear, and matchless both in the field and in counsel. While Vane headed off plots at Westminster, Ireton and Fairfax, and above all Cromwell, smote with a warlike efficiency scarcely ever paralleled. Royalism 
in Wales was trampled under foot. In Southern England, the King's cause, fiereely fought for about London, went down utterly at last in the fall of the stronghold of Colchester, in Essex; while Cromwell, in midsummer, with an army and Preston. small but perfect, sweeping in long detour from Western Wales to Central England, then far north into Lancashire, untouched by heat or fatigne, fell upon the flank of the invading Scots, and, eight thousand against twenty thousand, swept them from the earth at the battle of Preston. At the end of the summer all resistance had ceased; the Ironsides were master's of England, and their hands were hard. Presently the programme of the vietors was announced. The eaptains now stood thoroughly with their men and with the chiefs at St. Stephen's.

The Grand Army Remonstrance, ${ }^{2}$ written by Ireton, is the long and earefully preprared work of a scholar and lawyer. Though addressed to the House of ('ommons, it was intended Army lemonto express to the nation the position of to express ta the mation the piosition of an the Army, and the plim they meant to pursue. The attempt to treat with the King was solemmly denomeed: "though the Lord harl again latid bare his arm, and that small Army which they had ceased to trust. and had well-nigh deserted and cast off, hat been enabled to shiver all the banded strength of a seeond English insurrection, aided by Seotlank, - even after the rebuke from forl, were they not pusning the same phantom of anemmorlition?" The prineiple was lairl down that the "Representative Couneil of Parliament" must be sujerme:

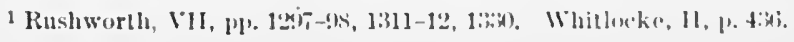


that any form of monarchy must be regarded as a creation of that freely elected council for special ends and within special limits; and that the monarch, if in any way derelict, could justly be called to account. It was urged that Charles deserved to be so called to account. If there were any hope of amendment, he might be treated tenderly. "If there were any good evidence of a proportionable remorse in him, and that his coming in again were with a new or changed heart, . . . his person might be capable of pity, merey, and pardon, and an accommodation with him, with a full and free yielding on his part to all the aforesaid points of public and religious interest in contest, might, in charitable construction, be just, and possibly safe and beneficial." But the King had been utterly faithless, it was urged, and continued to be so. In a passage showing how thoroughly they penetrated the King's falseness, it was declared that even now, after his complete second ruin, he was plotting and prevaricating, while secretly expecting aid from the Irish rebels. "Have you not found him at this play all along, and do not all men acknowledge lim most exquisite at it?" At length came the immediate demands, and, first, that the King might be brought to justice; that his heirs, the boys afterward to be Charles II and James II, should return to England and submit themselves completely to the judgment of the nation; and that a number of the chief instruments of the King in the wars should be brought with him to capital punishment. All obdurate delinquents were to undergo banishment and confiscation of property, and all claims of the Army to be fully satisfied. In the prospective demands, with which 
the noble document ends, the Army require: 1, a termination of the existing Parliament within a reasonable time; 2, a guaranteed succession of subsequent Parliaments, annual or biennial, the franchise to be so adjusted that Parliament shall really represent all reputable Englishmen; 3, the temporary disfranchisement of all who had adhered to the King; and, 4, a strict provision that the representation of the people should be supreme in all things, only not to re-question the policy of the Civil War itself, or touch the foundations of eommon right, liberty, and safety. In the polity indicated, the kingship, if kept up, was to be a purely elective office, every suceessive holder of which should be ehosen expressly by Parliament, and should have no veto on laws passed by P'arliament, in other words, an American President, - elected by Congress, however, instead of an Electoral College, and shom of his great power of the negative voice.

These were the idleas of the soldiers, but not of the majority of Parliament. While the Army-men had been setting forth their Grand Remon-

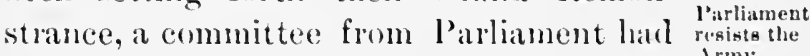
leen newotiating a new treaty with the Irmy.

King. 'The latter, untanght by his more rerent reverses, as also he had bren untaught by those of the earlier war, would make no concessions mpon which any reliance conld be placed. Nevertheless, the majority of Parliament voted for concluding peace with him, taking action which would have restored ('harles at once to the throne, jossessed of a power which would have enabled him to put an end strightway to those who hat mphed fresdom, and to all they had fought for. 'To seeure their own lives. to seeure 
what was more precious to them than life, the popular freedom for which they had been so long fighting, Pride's Purge. only revolutionary means were now adequate: Colonel Pride took his place at the door of St. Stephen's and turned out one hundred and forty-three members, cutting down the Long Parliament into the famous Rump, in which none were allowed to sit but those who accepted the principles of the Army.

As to Pride's Purge, it is hard to see, at the present time, what other course it was possible for the Army to take in order to save their cause. Nothing can be Ireton's decla. finer, at any rate, than the manifestoes of rations. Army and Rump at this crisis, for the composition of which Ireton must be especially credited. "We are not," it was declared, "a mercenary Army, hired to serve any arbitrary power of the state, but called forth and conjured by the several declarations of Parliament to the defence of our own and the People's just rights and liberties; and so we took up in justice and conscience, to those ends, and are resolved ... to assert and vindicate them against all arbitrary power, violence, and oppression, and all particular interests and parties whatsoever."

What were the ideas with which this wonderful Rump, still the Long Parliament, though purged, began its career? The 4th of January may be set down as the beginning of the new order of things. That day, it was resolved by the little company now left in the great emptiness of St. Stephen's - for not only were the exclucled members absent, but many timid ones, - " That the Commons of England in Par-

1 Commons Journal (under date). 
liament assembled do declare, that the People are, under God, the original of all just power; and do also deelare, that the Commons of England in Parliament assembled, being ehosen by and representing the l'eople, have the supreme power in this nation; and do also declare, that whatsoever is enacted or declared for law, by the Commons in Parliament assembled, hath the foree of a law, and all the People of this nation are coneluded thereby, although the consent and concurrence of the King or House of Peers be not had thereto."

A declaration was reeeived from the Army on January 15th, the day the eharge was read against the King. The Army urged: "That having sinee the end of the last war waited for a settlement of the peace and government of this nation : and having not found any such essayed or endeavored by those whose proper work it was, but their many addresses and others in that behalf, rejeeted and opposed, and only a eorrupt elosure endeavored with the King on terms serving only to his interests and theirs that promoted it, and being thereupon ... necessitated to take extraorlinary ways of remedy, - they have at last finished the dranght of such a settlement in the nature of an Igreement of the People for peace among themselves, it containing the best and most hopeful foundations for the peace

The Agree. me'nt of the leople. and future well government of this nation, that they ean possibly devise. And they appenl to the conseiences of all that read it, to witness whether they have therein provided or propounded anything of advantage to themselves . . a alove others, or andich lut what is as good for one as for another: not doult- 
ing but that those worthy patriots of Parliament will give their seal of approbation thereunto, and all good people with them. But if God shall suffer the People ... to be so blinded ... as to make opposition thereto, ... they hope they shall be aequitted before God and good men from the blame of any further troubles, distractions, and miseries to the kingdom, which may arise through the neglect and rejection thereof."

On the 20th, the Agreement of the People ${ }^{1}$ was formally presented. It has the name and many of the ideas of the manifesto of the Agitators, in the fall of 1647. It has become now a detailed and definite scheme of government on which we can well afford to dwell.

In 1647, Ireton, to whom the bold and masterly elaboration was for the most part due, had not been ready for so radical a step, and had left the couneil abruptly, as we have seen, at the suggestion of laying by the King; but in the Army now, rank and file and chiefs stood together. The paper consisted of ten articles. The 1st demands the dissolution of the present Parliament by the end of April, 1649. The $2 d$ assuming that the supreme power in England is thenceforth to be a single representative House, declares that every such future "Representative" shall consist of four hundred members, or not more, and distributes these, with great care, among the shires, cities, and boroughs of England and Wales. Yorkshire is to send twenty members; Deronshire, seventeen; Middlesex, fourteen ; Cornwall, enormously over-represented hitherto, eight; and so until we

1 Gardiner: Documents of the Puritan Revolution, p. 270. 
reach the small counties of Rutland and Flint, which have but one each. It is worth while to speeify to some extent in order to see how remarkably the reforms of 1832 were anticipated. The 3d gives the time of meeting and defines the qualifications of the electors and the eligible. All men of full age and householders, except paupers, and (for the first seven years) armed adherents of the King in the late wars, are to be the electors. The eligible are to be those qualified as elector's, with restrietions designed to keep out for the first few Parliaments the King's partisans. The th considers the matter of a quormm. The 5th is very important, requiring every Parliament, within twenty days of its first meeting, to appoint a Council of State, to be the acting ministry or government in co-operation with itself, and also in the interval, between it and the next Parliament. Passing over the $6 \mathrm{th}_{\mathrm{l}}$, 7th, 8th, as relatively unimportant, in the 9 th we find the relation in which the govermment is to stand to the Chureh. Christimity, it is hoper, will be the permanent national religion: Parliament may establish any form of ehureh not popish or prelatic; dissenters are, however, to be tolerated and protected, the liberty, nevertheless, not "neerssarily to extent to Popery or Prelacy." The 10th defines treason and indieates what in the proreding artioles shall be held as essential.

Except the 8th article. reliating to the religinns

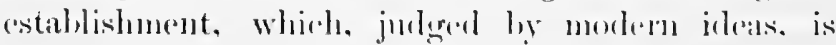
narrow, there is mothing here not most themenglily reasonable. Ireton himself, like Cromwell and Vane, was ready for the broalest toleration, inchuling even 
Jews, infidels, and Pagans; but even in the Rump, there were prejudices that must be humored. On the 6th of February it was resolved: " "That the House of Peers in Parliament is useless and dangerous, and ought to be abolished," and on the following day, "that the office of King ... is unnecessary, burdensome, and dangerous to the liberty, safety, and public interest of the People of this nation, and therefore ought to be abolished." The old order was thus completely swept away, and England was a Itsanticipa- Republic. The English reforms already tion of mod-
ern reforms. in progress at the present hour, were all anticipated: all, too, that is most essential in the American system had been formulated. The great change was marked by the execution of the King, which took place January $30,1649.2$

Thus we see that popular government, the heritage from the ancient Saxon time, seemed likely to have - in the days of the Ironsides a most complete and memorable revival. It is to be noticed that it came about as something into which people were forced, rather than something which they voluntarily embraced. Eliot, Pym, and Hampden never conceived for England of a polity in which King and Lords should be swept away. It was the rank and file of the Army, the plain people, the tradesmen of the towns; or rather, since the towns in great majority became Presbyterian, it was the small farmers, the yeomen, from whom proceeded the first assertion

1 Commons Journal (under date).

2 The preceding summary is taken from the author's life of Vane, Chapter XIV, which see for fuller details. 
of a complete right to self-government. Their own leaders at first held back, in some cases denouneing so thorough a sweep. At last, however, Cromwell, Ireton, Vane, and Milton stood thoroughly with the men, - justifying themselves in their course by the belief that they undertook no new thing, but only restored the essentials of that most ancient freedom that liad been so deeply overlaid. ${ }^{2}$ These were the prineiples of the Independents, - the Ironsides, namely, and the Rump, the mutilated Parliament which represented them at St. Stephen's. Did the principles take effect at once?

By no means. All Europe was against the Independents. Of the whole English nation, they eould count for sympathy only upon about two-sevenths. The remaining five-sevenths were their bitter enemies. The old Cavaliers preferred to freedom the despotism of a King; the Anglicans among them longed for Prelaey of the Laul type; the Catholies, for a hierarchy of the Romish model, - for a restoration of the monasteries, a displateing of all Protestant worship by the mass, and an acknowledgment of the supremacy of the P'ope. The P'resbyterians abhorred the toleration which was a cardinal principle of the victors, and hungered for the spiritnal despotism of the synod. The Army and the Rump, howerer, hoped to win the nation to their view, ampl resolutely went to work to maintain their position by the swort against the world in arms on every side. It was an alsurd gromm, in a certinin way, which they ocenpied: believers in the fullest froenlom, they songhtit to foree freedom "unon men who would rather lne in

${ }^{1}$ See the writer's "l.ife of Vane," for evidence of this. 
fetters. They were in their own hearts greatly troubled by the situation. Still their trouble of mind brought no paralysis, and they entered upon a career than which history has nothing more marvellous. Postponing until a more convenient time the reorganization of England, according to the Agreement of the People, they resolved for the present

Temporary government of the Rump and the Coun-
cil of State. to retain the Rump, organizing for an executive a Council of State $^{1}$ of fortynine, to be appointed annually by Parliament from the "Honest Party." All recognized this government as nothing but an oligarchy, a temporary expedient to which the heavy pressure of a difficult hour drove them. They had sketched, however, the general scheme of a far different constitution, and strove, even while they were fighting, to elaborate all the details so that it might be bestowed at the earliest possible moment upon the nation, if they could ever succeed in winning the nation to adopt their views.

The active enemies of the Commonwealth gave them not one moment's respite. Whether the execution of Charles was an unavoidable neces-

EmbarrassEmbarrass-
ments of the
Independents. sity, as Cromwell believed, or a melanIndependents. choly blunder of the "Honest Party," as Vane thought, it is even now impossible to decide. At any rate, it had this effect. The Cavaliers, everywhere horrified, were immensely stimulated in their desire to crush the men that had so far foiled them; and thousands who had before been lukewarm, or indeed, had fought zealously in previous years for the cause of the Houses, now ranged themselves among

1 Gardiner : Documents of the Puritan Revolution, p. 291. 
the Royalists. Luckily for the Commonwealth, its enemies were at ill accord among themselves. Catholic, Anglican, and Presbyterian could not cordially join. The odds, however, against the Commonwealth were tremendous, to be coped with only by the most consummate generalship and statecraft, combined with the most dauntless courage.

At once, Cromwell with twelve thousand men was thrown upon Ireland, where the Duke of Ormond, uniting all factions, presented a front full of danger. The sword has never done Ireland. work more sharp and swift. The strait for the Commonwealth was desperate, and desperate and bloody was the wrestle as it threw itself upon its foe. Victory was complete, and Cromwell was soon at home for other work, and none too soon. The young King, Charles II, had meantime landed in Scotland; had taken the covenant, in that way winning the enthusiastic support of the North, which before had, to a man, been horror-stricken by the execution of Charles I; and now, at the head of the whole power of Scotland, was preparing to win his father's throne. Prompt as the powers of fate, the Ironsirles faced him. They did not await the coming of the enemy, but rushed north to strike them in their own territory, if possilble, unprepared. Never, during his whole career, did Cromwell confront a host so dingerous as during August, 1650. It ontnumbered his own Dunbar. more than two to one; the hearts of the Srots, among the bravest of men, were thoronglily in their canse; their learler. David Leslie, was the boldest and at the same time the wariest sollier whom the world in that age could have sent against him. By skilful manceu- 
vring the Scots brought Cromwell to the verge of destruction. For a month, there was not a mistake, not an opportunity which could be used. Cromwell was penned into a little corner by the sea, his men fast sickening about him, his hope all but extinct. Just here the mistake was made. The opportunity was instantly seized, and out of it came the almost miraculous victory of Dunbar, where, with a loss of not more than thirty Ironsides, three thousand Scots were left for dead, ten thousand captured, and the rest driven in complete rout. Any but Scots would have been utterly overthrown. They, however, rallied and recruited with the truest grit; then while Cromwell in an unguarded moment was pressing on their flank, they rushed for England, raising the country as they went, and not halting until they reached the Worcester.

Midlands. At Worcester, however, all was over for them, and so far as Great Britain was concerned, not a hand could longer be raised against the Commonwealth. But it remained to teach Europe how formidable the new power had war with become. The ocean war with Holland folHolland. lowed, in which, with Vane as administrator and Blake to marshal the fleets, England first won the empire of the seas. Every foe was at last crushed.

Why, therefore, could not the Commonwealth be now established according to the plan of the Agreement of the People? In spite of the victories, the people had not been won; neither Rump nor Army dared to give the nation to itself; master of itself, there was sure to be on the part of the nation a surrender presently into the hands of the old tyranny. Just here came another of the series of momentous 
schisms that mark the history of this disturbed time. As the polyp, attaining a fair size, having encountered an obstacle, suddenly bisects itself, the divisions proceeding afterward on their way, or drifting into antagonism with one another, each a living organism independent within itself, ready to undergo at any moment new bisection, - so does the political party proceed in its development. England at the opening of the Long Parliament suddenly became Cavalier and Roundhead; the Roundheads, triumphing, presently became Presbyterian and Independent; the Independents having gained the day, it was now their turn to split. The cleavage came, and at the heads of the severed portions stood respectively Vane and Cromwell. Neither felt that a settlement $\begin{aligned} & \text { Schismamong } \\ & \text { the Independ- } \\ & \text { ents. }\end{aligned}$ could be left to a Parliament freely elected: if any advantage was to remain from the triumphs so painfully won over encroaching prerogative and privilege, the champions who had borne the brimt of the fight must retain a guirling power. The plan which Vane favored was to catuse a new Parliament to be elected; but the Rump was to jurlge as to the suitability of the members returned, and each member of the Rump was to have a seat in the new assembly. This function of the Rump was to be only a temporary makeshift, to be disearded at the earliest possible moment. To no one was such i limitation more repugnant than to the freedom-loving Vane; but only in this way, in his judgment, in the stress of that disturbed time, conld it be made certain that England would not go late to the Stuarts. Cromwell felt, on the other hand, that the Rump must be no longer tolerated: that, at any rate, must give 
way; and if England could not yet be trusted with its own freedom, he would himself, with a council of officers, "play the constable" and see that order was preserved until the better time should arrive. So Dissolution of came April 20, 1653, when Cromwell, the Rump. having turned out the members of the Rump and locked behind them the door of St. Stephen's, entered upon his constable's work which was to last through five famous years.

"The day never came when Cromwell felt he could cease to be a despot. With almost miraculous ability The autocracy he sustained himself, - ability no more conof Cromwell. spicuous in dealing with foreign and open enemies, than against the constant plots of secret foes. His old mother at Whitehall shivered whenever she heard the report of a gun, or an unusual crash, through fear that some assassin had at length found the heart of her son; - and it was no foolish fear! He tried repeatedly to surrender the nation into the hands of its own representatives sitting in Parliament: each time, however, there had been a questioning of matters which he thought should not be touched, and so each time, at the autocratic word, St. Stephen's had emptied itself, leaving all to the Protector's sword. He put aside the title of King, but a rule more absolute than that of any English King prevailed. Dividing England into military districts over each of which he set a major-general, a grim Ironside, whose sword was absolute, he ruled with an unconstitutional tyramy compared with which that of the Stuarts was mere ehild's play, - no more arbitrary, however, than it was beneficent, as potent to beckon into life all things great and good, as it was 
to dash into ruin all things that made for ill. Who that follows that wonderful career, that reads those letters ${ }^{1}$ and speeches, stammering, ineoherent, will abate a word from Milton's great panegyric?

" 'He was a soldier disciplined to perfection in a knowledge of himself. He had either extinguished or by habit had learned to subdue the Miton's panewhole host of vain hopes, fears, and pas- gyric. sions whieh invest the soul. He first acquired the government of himself . . so that on the first day he took the field against the external enemy, he was a veteran in arms.... The whole surface of the British empire has been the theatre of his triumphs. The good and the brave were from all quarters attracted to his camp, not only as to the best school of military talents, but of piety and virtue. His soldiers were a stay to the good, a terror to the evil, and the warmest advocates for every exertion of piety and virtue. While you, O Cromwell, are left among ns, he hardly shows a proper confildence in the Supreme, who distrusts the security of England. We all willingly yield the palm of sovereignty to your unrivalled ability and virtue, except the few among us who do not know that nothing in the world is more pleasing to fiol than that the supreme power should be vested in the best and the wisest of men. Sneh, () (romwell, all acknowledere you to be; sinch are the services which you have remelered ats the leatlor of omr couneils, the general of our armies, and the father of your country. Continue your eourse with the simme unrivalled magnanimity: it sits well upon you. To you our country owes its lilkerties, nor can you sus-

\footnotetext{
I See Carlyle's Cronwell.
} 
tain a character at once more momentous and more august than that of the author, the guardian, and the preserver of our liberties. Hence you have not only eclipsed the achievements of all our Kings, but even those which have been fabled of our heroes." " 1

When at last his mighty hand relaxed, nothing was possible but the Restoration. The world was in truth not yet ready. ${ }^{2}$

"Thus ended, apparently in simple catastrophe, the enterprise of projecting into sudden reality the imBenefits secured by the English Revopulse of spiritual freedom. Its only result, lution. as it might seem, had been to prevent the transition of the feudal into an absolute monarchy, and thus to prepare the way for the plutocracy under feudal forms which has governed England since the death of IVilliam III. This, however, is but a superficial view. Two palpable benefits the short triumph of Puritanism did win for England. It saved it from the Catholic reaction, and it created the dissenting bodies. The fifteen years of vigorous growth which Cromwell's sword secured for the church of the sectaries, gave it a permanent force which no reaction could suppress, and which has since been the great spring of political life in England." 3

1 Defensio Secunda pro Populo Anglicano (translation). See Life of Young Sir Henry Vane, pp. 414, 454, 455.

2 Gneist: Geschichte und bentige Gestalt der Aemter in Englaud, p. 226 , etc.

8 Thomas Hill Green: Lectures on the English Commonwealth. Works, III, pp. 363, 364 . 


\section{CHAPTER XI.}

THE REVOLL'TION OF 1688.

Charles II, 1660.

Jame日 II, 1685.
William and Mary, I689.

Anne, 1702.

The Commonwealth went down after its brave struggrle to establish sovereignty of the people, and a reaction began which went to great ex- The Restora. tremes. Charles II returned in the midst tion.

of enthusiasm so excessive that the stern Republieans who for some glorions years had had all things in their hands, were completely silenced. The new King, like his father and grandfather, was ready to claim high prerogatives. but his subjects showed a subservieney that surpuised him. Foremost in loyal zeal stood the elergy of the Angliean Church, which eame back over the temporary wreck of Presbyterianism and Independency, into a power greater than ever before. What were the reaction from claims of James I and the Royalists at the the ideas of beginning of the century. we have al ready wealth. noted. 'These doctrines of alsolutism, during the time of the Commonwealth so thomonghly repudiated. came at the Restoration again to the surface in forms more marked than ever. Every Anglican pulpit. and no other pulpits were now tolerated, - talughit. with the strongest emplatsis the divine right of kings. Writers arose who mulertook to show that Matgnit 
Charta itself and every constitutional law were rebellious encroachments on the ancient, imprescriptible prerogatives of the monarchy. ${ }^{1}$ The theories of a certain Sir Robert Filmer were especially in vogue, according to which the King stood above all law. He taught that the Supreme Being regarded hereditary monarchy with peculiar favor. No human power, no length of adverse possession, could deprive a legitimate prince of his right: his authority must of necessity be despotic; the laws by which his prerogatives were limited were merely concessions of the King which he might at any time revoke: any treaty which he might make with his subjects'was simply a declaration of his present intentions, and not at all a contract the performance of which might be required. ${ }^{2}$ The theme which the clergy insisted on beyond every other was "non-resistance," - that nothing whatever in the way of crime or folly committed by a legitimate prince, conld justify subjects in rebelling. $\mathrm{He}$ might be imbecile or as cruel as Nero, but his will must be done. Charles was ready to claim much, but the Church accorded to him even more than he would have claimed. Extravagant, however, though the Church was in its loyalty, the temper of the majority, as reflected in Parliament, bore it fully out.

The student of history is disposed to think sometimes that the true benefactors of mankind have been the knaves and fools, rather than men

Benefits flow. ing from the bad characters of Charles II and James II. good and wise. What brought to pass

Magna Charta was the villany of John. The work of Simon de Montfort was pre-

1 Hallam: Constitutional History, II, p. 439.

2 Macaulay: History of England, I, p. 55. 
pared by the abuses suffered through the weak Henry III. Headstrong Richard II made a way for the constitutional rule of the Lancastrians. So now it must be said that at the end of the seventeenth century, Anglo-Saxon freedom was saved only through the cireumstance that the two Stuart kings were utterly unworthy men, - Charles II, a selfish, frivolous voluptuary; James II, a cruel and stupid bigot. What if the occupant of the throne during this mood of subserviency into which the people had so largely sunk, hai been a ruler really good and gifted, - a Charlemagne, a Louis IX of France, a Frederick II; - or indeed some one of the heroes of the Engrlish line, arbitrary but masterful, - a William the Conqueror, the second or eren the eighth Ienry, or Elizabeth? It must be believed that in such a case the fire of freedom would have become extinguished. It was the abuse of power only, by Sovereigns vicious and ineapalle, that brought the people to their senses.

As the reign of Charles proeederl, his private character grew constantly worse; as he samk himself, his example drew his cont more and more deeply into the shomgh of lirutal vice. Fored into Ilis public policy, also, plunged the nation resistance. into ever-inereasing disgrace. He sold himself to Lomis XIV, engaging the power of his kinglom to airl the selfish selhemes of France. He forsonk his hest friends, the hishops and priests of the established chureh, offering for at bribe to beerome a cittholie, and dying at last in the profession of that faith. James II eame to the throne an arowed canholice. Though his faith was abhorrent, the Angliean ('hureth 
in a mass, many of the nobles, and the great majority of the country gentry, were at first ready to be consistent; they adhered to the doctrine of nonresistance and let the new King do his will. But every day it grew plainer that James could not be endured. His chosen instruments were Jeffreys of the Bloody Assizes, Kirk and his "lambs," and in Scotland, Grahame of Claverhouse, - torturers and executioners, who beneath the King's very eyes applied the thumb-screw and the boot, and multiplied everywhere the gibbet and scaffold, till mercy and reason seemed about to flee from the world. Abuses and cruelties stung the nation to resistance.

Though the work of the great Long Parliament had appeared to be utterly discredited and overthrown, it began to be plain that certain important things had been after all established. Subservient though the people had seemed, and unprincipled though the two royal brothers were, yet no effort had been made to set up again the Star Chamber and High Commission Courts. It was clear that no such illegality as the ship-money cxtortion could again be attempted. It was recognized that the constitution must be that of 1642 ; all the acts of the Long Parliament which had received the sanction of King Charles I before the outbreak of the Civil War, were admitted. ${ }^{1}$ A sufficient number had become so sick of absolutism as to make possible The Bill of that statement of the fundamental prinRights. ciples of the constitution contained in the instrument known as the Declaration of Rights. It was prepared by a committee of which the illus-

1 Macaulay: History of England, I, p. 119. 
trious Somers was chairman. It began by recapitulating the crimes and errors which had made a revolution necessary. James had invaded the province of the legislature, had treated modest petitioning as a crime, had oppressed the Church by means of an illegal tribunal, had, without consent of the Parliament, levied taxes and maintained a standing army in time of peace, had violated the freedom of election, and perverted the course of justice. The Lords and Commons once more in Parliament asserted the ancient rights and liberties of England; the dispensing power had no legal existence; no money was to be exacted without grant of Parliament; the right of subjects to petition, of electors to choose representatives, of Parliament to free debate, of the nation to a pure and merciful administration of justice, all these were solemnly aftirmerl. The Declaration of Rights, made law by Parliament, became the Bill of Rights. James was deposed, and Mary, his dlanghter, with her able husband, Accession of William. Prince of Olange, becime King and Queen of Englind. Both were Stnarts; for William, as well as his wife, was a gramlehild of Charles I. Both, however, were sturlily l'rotestant. decent in their lives, and personages of sense and strength. With William and Mary legan for Eingland a better time.

'To appreciate the momentons chander of the Revolution of 1688. a glanee must be alast at the aomelition of other civilized rountries at that diy. France, Spain, and Italy, though nations. lixtinction of of Latin stock, had received in the early contiuent. 
centuries of the Christian era a strong Teutonic infusion, and at one time had possessed, as we have seen, institutions characterized to some extent by the same Teutonic freedom which had gone with the AngloSaxons to the island of Britain. ${ }^{1}$ In Germany and Scandinavia the stock was more purely Teutonic, and in those lands the polity of the forefathers had long endured. Russia, though Slavic, was at any rate Aryan, and her people possessed in the mir a village community as marked in its independence as the tuns and burhs of the Anglo-Saxons. In all these countries, however, the traces of popular freedom had long been effaced. The old national assemblies in France, Spain, and Italy had nearly or quite disappeared. The perishing of liberty under the blight of despots had been in Germany and the northern lands even more complete; in Russia, the local self-government had proved utterly sterile as regards resources for coping with the greed of tyrants. Only in Switzerland there smouldered in valleys almost inaccessible the embers of freedom, by the great world unnoticed and indeed unknown. Holland, to be sure, had wrenched itself from the grasp of Spain, but had fallen apparently into the hands of an oligarchy. Throughout Europe the right of the great to make laws and levy taxes was undisputed; thrones were guarded by regular armies; the prompt penalties for any criticism of the rulers were the dungeon and the scaffold. Again and again the same calamity had been imminent over England. But for Langton and the Barons, in 1215, what might not John have done? Had factious nobles pressed less

1 p. 62. 
heavily upon the Lancastrians, could the noble constitutional programme described by Fortescue ever have become real? Had the Tudors dared a little more, or had the one man Strafford not been taken from the right hand of Charles I, where eould freedom have harbored? These erises, as we have seen, had all been safely passed. With the promulgation of the Bill of Rights, the erisis of 1688 was also safely passed.

The deposition of James II stands in history under the name of a revolution: it, however, was a strictly defensive movement, having on its side Revolution preseription and legitimaey. ${ }^{1}$ The mon- of 1688. arehy as limited in the thirteenth eentury had come down to the seventeenth century. Parliament had behind it a past of four hundred years. The constitution was not formulated, but its prineiples, scattered throughout time-honored statutes, were engraven on the hearts of Englishmen. No one of its principles was based upon precedents more ancient or more frequent, than that Kings reigned by a right in no respeet differing from that ly which linights-ofthe-shire exercised anthority in helatf of their constituents." The Bill of Rights simply affirmed this principle. Not a single new right was given to the people; the whole looly of linglish law was unchanged; all was comblueter in obedience to the ancient formalities. The Revolution of 1tiss derided that the popmlar element in the buglish polits of such ancient derivation, so often bought rery low and yet never extinguished, slombl onde more survive. In 1688 , the old land in this struggrle angainst

1 Macaulay: History of Eingland, I, 1, 51t, etc. 2 lhit.., 1. 2lti. 
autocracy which we have seen so often renewed, for the last time stood alone. When next the conflict was joined, forces were to appear from a new hemisphere. The time was now not far off when popular liberty was to start up into a life no longer environed by perils, but clearly revealed as destined for the dominion of the world.

For many years after 1688 , it seemed most doubtful whether the principles of the Revolution could be whigs and maintained. Two great parties, the Tories Tories. and the Whigs, coming into existence at the close of the seventeenth century, have persisted unchanged in name and in general characteristics until the present day. The Tories accepted the doctrine of the divine right of Kings; and when consistent, were ready to obey a Herod or a Caligula, if only he were in the legitimate line; and to depose an Alfred, if he had come to power through any irregularity in the succession. To the Tories belonged, first of all in zeal, the Anglican clergy with all whom they could influence, many of the great nobles, and a great majority of the country gentry. A great part of the Tories were at first ready even to sustain such a sovereign as James, though in the end a sufficient number were so far estranged through his attacks on the Church and the constitution, as to make possible his deposition. The principle of the Whigs, on the other hand, was that the King was the creature and servant of the nation, which could justly set him aside if he were wicked or neglectful; the supreme power rested with Parliament. The hopes of freedom, of course, were bound 
up with the success of the Whigs, whose strength lay in a certain proportion of the higher aristoeracy; in what was left of the yeomanry, unfortunately now fast diminishing in number; and in the conmercial classes, who had become immensely important. As all over whom Anglicanism had power were almost necessarily 'Tories, so all non-conformists were almost necessarily Whigs. The eommercial classes and the non-conformists were, to a large extent, one and the same, - a statement which per- part played by haps may be said to have a general appli- $\begin{gathered}\text { formists and } \\ \text { commercial }\end{gathered}$ cation. "'lade is most vigoronsly earried classes. on in every state and government by the heterodox part of the same, and such as profess opinions lifferent from what are publicly establisherl." Lecky, quoting this remark from the "Political Arithmetic" of Sir William Petty, ${ }^{1}$ aseribes what he believes to be a fact, partly to the accessibility of town populations to new ideas, and partly to persecuting laws which, in the Stuart days, divorced dissenters from the soil and drove then to shop, work-bench, and ship. Among the mannfaturers and traters of Eingland now also were many of foreign stork. Thousands of skilled artisams. expatriated as hereties foum ('atholic lamks, hat gone into exile.

Spain and France thos experienced a loss from which they have never reeovered: while fiemany, Ilollamel. and England received ants before moknown anomg them, and an areession of the finest manhend. No comintry owes more to hor toleration than Fingland." For nearly two humbled years, at stream pumpel in of

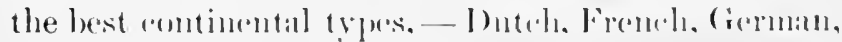

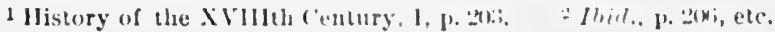


and, after Cromwell, Jewish, - until the commercial classes were thoroughly pervaded by them. About $1700, \cdot$ there were in London thirty-five Huguenot churches, and many elsewhere. The hospitality of the native English, indeed, to strangers has been far enough from generous. Chaucer commemorates the hostility of the common people of his time to the Flemings $;^{1}$ and long after the fourteenth century, many an industrious alien lost home and even life in riots born of jealousy. Usually, however, worthy immigrants could find foot-hold and thrive: if parents suffered, the children grew thoroughly into English speech and ways, while inheriting skill and industrious habits that had come from beyond sea. Such refugees, especially numerous after the Revocation of the Edict of Nantes, threw their influence to a man, on the side of the Whigs: their persecutions came from Kings who were friends and allies of the Stuarts: what patience could they have with the idea of the divine right? To a man, also, the refugees became non-conformists; for aside from the Toryism of the establishment, what attraction could a church so near in its constitution and rites to the Catholicism they loathed, possess for men so strongly Protestant !

At the opening of the eighteenth century, the Whigs were full of ability and energy, and it was all required

Doubtful struggle between Whigs and Tories. for the battle to be waged. The Tories were powerful and probably in the majority, and would have so far prevailed as to overwhelm the cause of the people but for a fortunate chain of circumstances. William and Mary, the only

1 Nonnes Prestes Tale. 
man and the only woman of the evil line proceeding from Darnley and Mary Queen of Scots, who have possessed real character and ability, died without issue. By a happy chance, the Pretender, the alleged soln of James II, weak and vicious in all his qualities, and rigidly Catholic, was of doultetul birtl.. There was reason for believing that he had been a supposititious child, and this suspicion under which he lay prevented the zealous action of the Tory disposition. Could it have been made eertain that the Pretender was a Stuart, there were enough upholders of the doctrine of divine right to carry him trimmpliantly into power, though the worthlessness of the line had proved to be so inveterate. The death of Anne was a crisis about which the lover of freedom must read even now with bated breath. The Protestant succession prevailed, but barely so. A race of princes, the house of Brunswick, came in, of no mark, to be sure, either as to virtues or gifts, but at leist they were pledged to constitutional rule. The right of Parliament was not to be questionerl, and the idea of the jus divinum began to decline. As time passed, the landed gentry, and in a great degree the elergy, became reconcilerl to the Hanoverians. In $17+5$, when for the last time a Stuart made an effort to gain the English crown, his partisans, few and without spirit, were suppressed.

With the micllle of the eighteenth century, the English politieal forms as we know them at the present

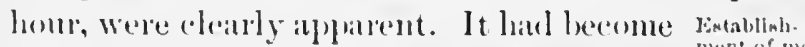
fixerl that the supreme power in the state $\begin{gathered}\text { mont of monl } \\ \text { ern forms in } \\ \text { the lingling }\end{gathered}$ Was l'arliament; in Parliament stood over polity. agranst earh other the two great parties of Whigs 
and Tories, the power shifting now to one, now to the other. Parliament had taken to itself, in addition to the legislative function, the executive function as well; a committee, appointed by the Sovereign from the party for the time being in majority, known as Rise of the the Ministry or Cabinet, exercised these Cabinet.

functions. This device of an executive ministry, changing as power changes from one party to the other, was adopted under William and Mary, and under the name of Responsible Government, has come to play a most important part in the polity of the English-speaking world.

But the Revolution of 1688, though an event to be thankful for, brought about only partial benefits.

Unsatisfac.

The outcome under William and Mary Unsatisfac.
tory condition was something very different from the
of Yarliament.

freedom for which the Ironsides had schemed and fought, which Cromwell through all his arbitrary course strove to make real, and for which Vane laid his head upon the block. Absolutism in the Sovereign was crushed out effectually, but England fell into the hands of an aristocracy and a plutocracy, the mass of the people being as completely unrepresented in the government as in many a despotism. King, Lords, and Commons stood after the old fashion, for which Pym and Hampden had struggled in the first years of the Long Parliament. The power of the House of Commons was largely increased, but the men who sat upon the benches at St. Stephen's had ceased almost to represent the nation at large. In Earl Simon's plan and for long after, Parliament had made substantially real once more the ancient national assem- 
blies. Each freeman indeed could not come himself to the deliberations; but each freeman had a voice in determining who should stand in his place and speak his will, - from each shire the two discreet knights, from each borough the delegated burgess. In the Parliament of the eighteenth century this condition of things did not exist. It had come about that a portion of the seats of the House of power of the Commons were practically owned by great $\begin{gathered}\text { nobles and } \\ \text { men of }\end{gathered}$ nobles, who filled them with subservient wealth. creatures. The nobles sat at the same time in the House of Lords. To their direct power as peers, therefore, was added a vast, indirect power, obtained through their influence in the lower House, a power so great that it approached the proportions of an oligarchy.

Still another element in the mation had come to wield a portentous influence. The growth of a great commercial class was undoubtedly on the whole a good, but it was not a good nmmixed with eril. Merchants and manufacturers became possessed of wealth: the colonies and establishments of the large trading companies in the West and in the ()rient offered opportunities to the bold and rapateious which were eagerly embrated. Men grew rich at home, in the East and West Indies, in Amerieal. Not satistied with riches, they desired also power. By the seore they bought their way into the House of Commons, showing no sernple about employing corruption: as on the other hambl the degenerate constitueneles had no seruple about anedpting the bribes that were offered. By the side of the vast power the molles harl seized, a dangerous plutoracy hatd plated it 
self. The bearing upon the fortunes of Anglo-Saxon freedom, of the condition of things which had come to pass in the middle of the eighteenth century, is so important as to require careful consideration. 
ERA OF PARLIAMENTARY CORRUPTION. 177

\section{CHAPTER XII.}

\section{ERA OF PARLIAMENTARY CORRUPTION.}

George I, 1714. George 1I, 1727. George III, 1760 .

Is the middle of the eighteenth century no one thought of questioning the principles of the Revolution of 1688 . The doctrine of divine right

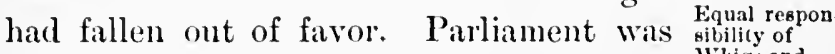
reeognized as the supreme power in the Thiigs and State. We have to consider now the de- larlianengeneracy of Parliament, the extent to which it had ceased to represent the nation and fallen a prey to corruption. At an earlier time, when the Sovereigns had been more powerful, there had been little corruption: it was much cheaper to coerce or intimidate a knave than to huy lim. For a very different reasom, there is little direct buying of votes in onr own time. The nation now lowds Parliament strictly aceomtalble to itself: everything is thoroughly ventilated in the newspapers: pullic opinion holds all in fear. But between the time when the kings influenced Parliament, and the time when public opinion beran to make itself felt, there was an interval during which corruption was searcely olpposed. This interval extenderl from less until the elose of the war with Ameriris, in 1783. 'The great 
parties were about equally concerned in the abuse: the Tories were the first to begin it and the last to give it up, but it was most vigorous under the Whigs. The best men of the period connived at it. Stooping of
honest men to Said King William to the remonstrating
bribery. bribery. Bishop Burnet: "Nobody hates bribery worse than I; but I have to do with a set of men who must be managed in this vile way, or not at all. I must strain a point, or the country is lost." Bribery was never worse than under the ministry of Pelham, 1745 to 1754 , a statesman undoubtedly of good purposes and character. $\mathrm{He}$, too, felt forced to pay greedy and low-minded men not to ruin the country. There were other men in places of power, of the most honest dispositions, whose fingers, nevertheless, became touched with the pitch: they were entirely above receiving bribes themselves, but they felt forced to bribe others. ${ }^{1}$

In the House of Commons, from the time of Simon de Montfort, the two great divisions under which the members were naturally classed were those of county-members and borough-members. Taking each class by itself, let us review, at some risk of repetition, the influences to which it had been exposed, and the condition into which it had fallen at the time of the accession of George III, in 1760.

The county-members were the knights-of-the-shire, whom the constitutional historian has occasion to Degeneracy of mention so frequently as playing a most Degeneracy of
the county rep-honorable and useful part. These were
resentives. elected in the shire-moots, in which in early

1 Macaulay: History of England, III, p. 429, etc. Green: History of the English People, IV, p. 125, etc. 
times appeared not only great proprietors, but a multitude of small free-holders, the independent yeomen, that body of the population drawing its blood to such an extent from the ancient Anglo-Saxon sources, and retaining to such an extent the ancient AngloSaxon traditions. That the knights-of-the-shire in early times were stanch spokesmen for freedom, was undoubtedly due to the fact that the constituencies which sent them to Westminster were composed so largely of yeomen. In the midldle of the fifteenth century, the golden age of the English yeo- Decline of the manry, Forteseue declares that in no other yeomen. country of Europe were the small landed proprietors so numerous, and he attributes to this cireumstance a large part of the well-heing of England.' Through trade, however, which beeame vigorous soon after, as new lands and new seas were opened to commeree, individuals grew rieh, the increase of wealth resulting in the accumulation of great estates in which the small free-holds began to be alsorberl. The growth of the woollen trade, with the high rate of agrienltural wages, under IIenry VII, made it protitable to turn arable land into pasture; so that, instead of a number of independent farmers a single shepherd often became the administrator of a wide tract. This process went on, until in Elizalethan times and afterward, there was bitter eomplaint because the farmsteads of the yeomanry were becoming to such an extent ahoorhed in sheepwalks. More, Ascham, Latimer, Strafford, and Baron, as we have seen, textifiorl to the evil, and there was legislation to comnteranet it. $\Lambda$ the time of the Civil War, the yeomen, though

1 De Iaudibus Iegum Angliae, XXIX. 
diminished in numbers, still constituted, as we know, an important part of the strength of the Parliament, whose side they generally embraced. After the Restoration, however, the diminution became more rapid; the small free-holders now and then rose into the rank of county gentry; but in far larger proportion they gave up their farms, and fell into the condition of peasants; in which case, as the franchise depended upon owning land, they lost all political power. ${ }^{1}$ The franchise in the shires, therefore, by the middle of the eighteenth century had fallen Assumptions of the great into the hands of a comparatively small number of land-holders, whose numerous tenants and laborers had lost all voice in the public management. These great land-holders were in part nobles, already possessed of large political power as members of the House of Lords; in part, wealthy traders or manufacturers with fortunes won in legitimate commerce; in part, men enriched through fortunate speculation, through the labor of negro slaves, or through the oppression of mild-mannered natives in Hindostan. This great change in the character of the county constituencies did not fail to affect, and disastrously, the character of the representatives. Nevertheless, the shire-members remained as of old, the purest and most respectable body in the House of Commons; for the borough representation, exposed to influences still more unfortunate, had sunk into a condition far worse, as will now be shown.

1 Lecky, I, p. 7; he cites Eden: History of Working Classes, I, pp. 73, 115. Macaulay, Chap. III. Fischel on the Constitution, pp. 315, 316. Thornton : Overpopulation, chapter on English Peasants. Bacon : Henry VII, and True Greatness of Kingdoms. 
The boroughs, even in the thirteenth eentury, exhibited great irregularities in their constitutions. City and borough courts corresponding to hundred or shire moots, had probably once existed, but few traces of them remained. ${ }^{1}$ Bad condition of the boroughs.

There were municipalities in all stages of development, large and small, ancient and recent; and the limitations of the suffrage among them were as various as possible. In some, the right to vote was quite unrestrained, possessed by all who paid a tax; in others, the right belonged to a small body which at the same time was self-elective; in legal phrase, a close corporation. Between these two extremes, boroughs could be found in numerous forms of intermediate condition.

As time progressed, the tendency was to eurtail, rather than inerease, the largeness of borough life. Toward the end of the fifteenth eentury,

especially, many charters were issued by ofthe poputhe Crown conferring the power of governlar franchise. ment in municipalities upon eomeils that were either close corporations or elected liy a few of the wealthier burgesses. 'To these comcils solely belonged the riglit to choose the member of Parliament ; or sometimes to a still more restrieted body known as the "Seleetmen." 'The preple at large came to feel little interest in the member in electing whom they had had no voice; and the memlere, on his part, felt nue responsibility to the people. looking to the hamblful who chose lim as his propere constitneney. What oploptunities for cormption were now opened lexame at once alparent. 'The small cligpues of electoms in the

2 Sir T. Erskine May : Constimlional Hislory, H, Chap, XV. 
absence of all restraint from public opinion, could easily be bought up by rich men, by nobles, or by the Crown, and evils began to prevail which lasted for centuries. 'The rising power of Parliament induced the Tudors to resort to an expedient especially pregnant with harm. Finding that court-bills could not always be passed, they resorted, in order to manufacture a power for themselves, to the creation of Rotten bor"rotten boroughs"; that is, the conferring oughs. of municipal privileges upon places of small account, the representatives for which, appointed practically by dictation, were expected to show subserviency to the power which nominated them. Of such rotten boroughs, Henry VIII created sixteen; Elward VI, twelve; Mary, eight; and Elizabeth, thirty. ${ }^{1}$ To make it more sure that there should be no disappointment as regards a representative of proper quality, the office of high steward was often created in the boroughs, a functionary under the Crown, who pretty much superseded the mayor and council, and returned the member to Parliament without reference to any other anthority than his own.

The Stuarts earried on the work which the Tudors had begun, Charles II and James II annihilating Theirgrowth popular freedom in the few corporations under the Tu- which retained some vestige of it. The
dors and Stuarts. parliamentary reformers. of 1688 wished to make the representative body a more faithful interpreter of the constituencies; but it scarcely occurred to them, apparently, that the constituent body might be an unfaithful interpreter of the sense of the

1 Ransome: Rise of Constitutional Government in England, p. 113. 
nation. In the towns and eities, the abuses continued. Small eliques or individuals held the power and returned the members, and meantime many of the towns were becoming important centres of wealth and popmlation. The people were shut out, while the little knot of political masters, elected for life and generally carrying on their proceedings in secrecy, had no sense of responsibility to them.

At the time of the accession of George III, 1760, the bad features of the borough representation had become exaggerated to an alarming extent. ${ }^{2}$ (ireat towns like Leeds, Manches- George III. ter, and Birmingham, which had come forward suddenly through commercial prosperity, were not represented at all. On the other hand, boroughs, like Old Sarum, on Salisbury Plain, upon whose borders rise the silent blocks of Stonehenge, with sheep nibbling the grass in the pasture at their base, but with searcely a human inhabitant, yet returned a member to Parliament. In such a case there was no pretenee of election, the member being a mere nominee of the grandee who owned the territory. Where there was a pretenee of election, the franchise was confined to very few, the tenlency being to restriet it more and more. At the borough of Buck- Case of Buck. ingham and bewdley, for instanee, the right lngham, etc. of election was contined to the bitilifi and twelve burgesses. Bath and salisbury were boroughts of some importance. the seats of bishops: but the franchise was searely more extemled in them. At the town of New Shoreham, on the coast of Sussex, there

1 Maeanlay : History of Fingland, 15, p. 2tis.

2 May: Constitutional History, II, Chap. XV. 
were about one hundred and fifty voters. The maCase of New jority of these had formed themselves into shoreham. a club, for some strange reason called the "Christian Club," which made a practice of offering their votes for sale, the avowed purpose being to extort as much money as possible at every election from the candidate brought in. In 1770, the members of the club sold themselves for $£ 35$ (\$175) a piece, after haggling with a number of different candidates as to the price. The circumstances were so outrageous that Parliament was forced to notice it; a statute against bribery, of 1762 , which had been pretty much a dead letter, was put in force, and New Shoreham was disfranchised for its conduct. It was admitted at the time that there were many similar cases. Sudbury, indeed, in Suffolk, pubof Sudbury. licly advertised itself. Oxford, seat of the university though it was, was sold by its corporation, which had absorbed all power, to the Duke of Marlborough and the Earl of Abingdon. The bargainers were, indeed, prosecuted, like those of New Shoreham, but with a more fortunate issue for them: the whole affair was laughed at as a huge joke and soon condition of forgotten. Scotland was even worse off scotland. than England. Edinburgh and Glasgow, populous as they were, contained each but thirtythree persons who had a voice in choosing the member of Parliament. Not a borough existed in the land which was not practically owned by some man of wealth.

The facts cited show that, bad as the condition of the county representation was, that of the boroughs was generally worse. It was not always so: in some 
parts of Great Britain, the shires kept pace with the municipalities in the race of degradation. The shire of Bute, in Scotland, for instance, with a The shire of population of fourteen thousand, had but Bute. twenty-one electors, of whom only one was an actual resident of the shire. At a Parliamentary election in Bute, "only one person attended the meeting, except the sheriff and returning-officers. He, of course, took the chair, constituted the meeting, called over the roll of free-holders, answered to his own name, took the vote as to Proses, and elected himself. He then moved and seconded his own nomination, took the vote, and was unanimously returned." 1

A brief sketch has been given of the degradation to which the House of Commons hade fallen, a degradation illustrated in great detail by the historians to whom reference is made. The people of Englind were quite unrepresented; an actual majority of the House of Commons was returned by a small looly; the best political traditions of the Anglo-Saxon race appeared to be forgotten. When at length statistics were presented with the idea of rousing the nation to a sense of its condition, it was found that seventy members were returned from thirty-five places in which there were searcely any clectors at all; that ninety members were returned by forty-six plines with less than fifty electors; and thirty-seven members by nineteen places having not more than me: hundred electors. Of great peers, loolding seats in the upper House and at the sime time largely controlling the lower House, the Duke of Norfolk eontrolled the

I May: Constitutioual Itistory, I, I]). 185, 1s; (he quotes from IIansard's D(bates). 
election of seven members; Lord Lonsdale, of nine; Lord Darlington, of seven; the Duke of Rutland, of six; and so on through the aristocracy. As patrons of boroughs or owners of vast estates in the shires, they were politically omnipotent, being regarded by the people, who had in large part lost all sense of their ancient birthright, as their masters beyond question. It was asserted at last that one hundred and fifty-four individuals, forty-five of whom were peers, returned a majority of the House of Commons.

Seats at Westminster became almost openly articles of bargain and sale. Early in the century, a seat had Price of Parli- been held at $£ 2500$; under George III the amentary
Beats. ularly to the rise of the "nabobs." Hundreds of Englishmen had gone in quest of fortune to the East and West Indies; there, at the risk of health and life, moved often by unscrupulous rapacity, they wrung wealth from the toil of negro slaves, or the oppression of gentle natives, who in the clutch of Hastings, Clive, and their companions, were like chickens in the claws of hawks. The portrait of the The nabobs. nabob was frequently drawn in the old plays and novels. Who does not know the sallow, ill-tempered old curmudgeon, home at last from his years of cruel over-reaching in a foreign land, with no more morals or good-nature than liver, - a spiritual and physical wreck, - his jaundiced face matching his ill-gotten gold - the terror while he lives of a group of toadying friends, who hope to pocket his rupees when at last his grasp relaxes? Scores of such nabobs, in the time of George III, by buying their way into Parliament, raised the price of seats. The 
country squires, who were comparatively respectable, were overborne by the wealth of the returned adventurers; even powerful nobles were no match for them.

Of course, representatives holding their seats by a general system of eorruption, or who were the mere creatures of some great Lord of Broad-acres, conld seldom turn out to be high-minderl, independent legislators. They could seareely fail to be themselves subservient or eorrupt. The bestowing of places, pensions, and actual bribes for parliamentary service was a matter of eourse. The best men in England, though with eyes open to the evil, felt forced to take part in it. Reference has been marle to the feeling of King William and of Pelham. The great Sir Samuel Romilly, at a later time, the man who hat the ehief hand in reforming the old sim- Sirsamony of guinary criminal cole by which even petty lomilly. lareeny might be punished with the death penalty, wrote: "This buying of seats is detestalle; and yet it is almost the only way in which one in my sitnation, who is resolved to be an independent man, "an gret into Parliament. To come in by a popular election in the present state of the represintation is quite impossible; to be plated there by some great lord, and to vote as he should direct, is to be in a state of eomplete depentence; and nothing remains but to owe a seat to the sacrifice of pait of one s fortune. It is tme that many men who buy seats do it as at matter of pecmiary spereulation, als a profitalub way of empleying theip money: they eitry an a pelitional tracle; they buy their siedis and sell their sotes."

In the midule of the eighterenth century, then, Parliat-

1 May: Constitutional Hlistory, 1, p. 22t). 
ment was supreme, but it had ceased to represent the

The people unrepresented. people. The meanest motives told upon it, and purchase had become more and more the means of entering it. Walpole, prime minister from 1721 to 1742 , organized corruption.into a system; and the Duke of Neweastle, prime minister from 1754 to 1761 , based, without concealment, his power upon bribery and borough-jobbing. These were Whig administrations. Under George III, the Tories did no better, $£ 25,000$ being spent, sometimes, in a single day to influence votes. The moral tone of public life was profoundly lowered: the social condition of the people, moreover, deprived of the suffrage, and influenced by the demoralizing example set by those high in station, sank rapidly toward the shameful. WVas the nation unconscious of the disgrace which had come upon it; and were no voices raised for a reform of abuses? By no means. The question exciting most interest about the year 1750 was the extreme corruption of Parliament, its subjection to the executive, and the danger of its becoming the oppressor, not the representative, of the people. Many began to think the country had gained little by exchanging an arbitrary King for a Parliament corrupt and tyrannical.2 In a few years we find Burke exclaiming, "The value, spixit, and essence of a House of Commons consists in its being the express image of the feelings of the nation." Still more emphatically another declared: "This House is not a representative of the people of Great Britain. It is the representative of nomination-boroughs, of ruined

1 D. B. Eaton: Journal of Social Science, V, 1.

2 Lecky: XVIIIth Century, II, p. 470. 
and exterminated towns, of noble families, of wealthy individuals, of foreign potentates," and he denounced the abuses.' Such, too, were the sentiments of the great Earl of Chatham.

The case of Wilkes, first heard of in 1761, produced the deepest popular agitation. Wilkes, a man of ability, and a strong champion of freedom, case of though unfortunately his eharacter was not Wilkes. good, had been legally ehosen to Parlianent in London. Parliament, assuming an authority which it had never possessed, twice declared Wilkes incapable, action which the people on their part met with energetic remonstrance, ending twice with a re-election of their rejected favorite. Great radical associations were formed. With the disturbances of this time began the influence of public meetings on Mass-meeting. politics. In towns masses gathered, as in the ease of the Middlesex electors; in the connties, too, were great assemblies, as in the case of the Yorkshire free-holders; and in these vast meetings it beeame a familiar ery that the House of Commons did not represent the people. The people at the same period discovered still another eliamel by wheh they conld make their lower felt. For the tirst time the debates in Parliament were made publie. Secrecy being now destroyed, a salutary feching of responsibility was forced upon members, who foumd themselves called sharply to aceome before a tribunal for which until now they had eared but little. 'The first great newspapers, moreover, were eoming into existence ; and these forthwith, as organs of public oponion, began a course of criticism upon public men, exitsper-

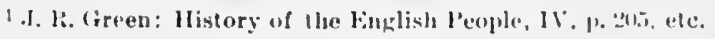


ating, often undiscriminating, and yet on the whole most beneficent. As the second half of the eighteenth century proceeded, a powerful party began to manifest itself, determined that Anglo-Saxon liberty should not be destroyed without a struggle. The party comprised a portion of those not disfranchised, - a few indeed of the great nobles: the mass of its members, however, were the unrepresented millions, the multitude so long subjected to the encroachments of the rich and great, until now they were quite thrust out of their rights. It was a party numerous, able, and quite ready to do valiant battle.

Nevertheless, the danger to freedom was appalling. The influence of foreign opinion and example were Dangers to . almost wholly for despotism. In the counfreedom. tries of Europe, what liberties had ever existed in the past were now completely wrecked. Popular freedom in Spain, Italy, and France had long ago disappeared. More recently most of the freedom of the towns of Flanders, Germany, and along the Baltic had been destroyed or transmuted into forms thoroughly inefficient: the Swiss cantons lay under the dominion of a narrow oligarchy. ${ }^{1}$ In the Old World, it was only the Liberals of England who remembered and were disposed to strive for popular freedom. Disfranchised as they were, opposed at home by the rich, the learned, the wellborn, entrenched in places of power and headed by a King of despotic disposition, whose capacity for mischief was increased by the circumstance that he was morally respectable and possessed some force of character, who will say that the outlook was not most

1 Lecky : XVIIIth Century, III, p. 242. 
critical? So thought, at any rate, many a lover of liberty, and some made preparations to expatriate themselves, as was done by the founders of New England when Laud and Strafford seemed likely to carry through their policy of Thorough. How Anglo-Saxon freedom in this crisis was saved to England and to the world is a very memorable story. 


\section{CHAPTER XIII.}

THE COMING ON OF THE AMERICAN REVOLUTION.

1700-1776.

THE English colonies on the Atlantic seaboard of America, from feeble beginnings, had become in a Condition of the 'Thirteen Colonies in the first half of the eigh. teenth century. century and a half communities populous and full of resources; but holding little communication with each other, and varying much in spirit and polity. In Massachusetts, which had absorbed Plymouth, and which also comprised Maine, thus becoming by far the most important colony of the North, the people were distributed among two hundred towns, each governing itself in its town-meeting, which reproduced with curious accuracy the moot-government of the primitive Teutonic community. As each Teutonic tun sent representatives to the higher moot, so each Massachusetts town sent a representative to a central assembly at Boston. There the deputies met a Crown-appointed governor, and also a council, in constituting which both assembly and governor had a voice. After the same general plan were ordered the remaining New England colonies. The oligarchic features of the earlier years had quite disappeared; not only church-members, but each reputable freeman had a vote; and, except for some restraint 
imposed by the Sovereign, the polity was thoroughly democratic, a resuseitation of forms most ancient.

Virginia, on the other hand, by far the most important colony of the South, resembled in her constitution contemporary England. A class of great planters, forming a landed gentry, possessed the territory and also all political power; while a numerous body below them was without estates and also without voice in the politieal management. While here and there divisions eould be made ont corresponding to the contemporary English parishes, like them called parishes and each governed by its vestry, the real unit of political life was the county, administered by its Court of Quarter Sessions, closely similar to the institution of the same name, which, in the mothercountry, had replaced, except for elective purposes, the slire-mont. In one respeet, Virginia differed widely from the mother-country, - full half her population were negro slaves. For a central government there was a governor, a eomncil, and a representative assembly. After the same general plan as that of Virginia were orelered the other Southern colonies.

In the midlle eolonies, luth society and institutions were far from homogeneons. In Xiw lonk, to the original 1)utell, the Einglish had been added, and to these again a Cierman clement; the young wity at the month of the IJudson was mate up of wails of all nations. () portions of the territory stowe towns seareely differing from those of Xin lingland: om

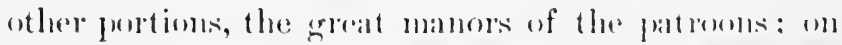
still others, some simple patriarelarl form of communnity. In Pemsylyania and Marylamel, the state was

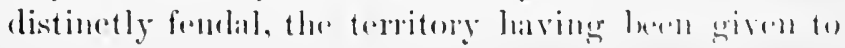


great proprietors who stood almost in the relation of suzerain to a great body of tenants. In Pennsylvania, the principal stock had been English Quakers; but a stream of Irish, Scotch, and German immigration had poured into the back settlements, which showed often small respect for the authority or the instructions of William Penn. Here the ancient shire-moot had reappeared with noteworthy vigor. In Maryland the proprietary was a Catholic, and the colony was largely of Catholic refugees. Circumstances, however, had induced Lord Baltimore, a man of liberal instincts, to practise a quite un-Roman toleration. Maryland harbored Puritan, Episcopalian, and unbeliever, - a company quite too motley in character for a harmonious social condition. For each of the middle colonies, too, there was a governor, council, and assembly. The Thirteen Colonies had at least this point in common, that in each colony there was an element, and it was sometimes the ruling element, of men and women who for conscience' sake had fled westward to avoid persecution. Sometimes it was the persecution of a hostile church; sometimes of a tyrannical prince; sometimes of the English Commonwealth. Such people were sure to be earnest and of sturdy moral fibre. Probably no nation ever started on its career with a larger proportion of strong characters, or a higher level of moral convictions. ${ }^{1}$

How, precisely, did it come about that the Thirteen Colonies declared themselves independent? ${ }^{2}$ In the

${ }^{1}$ Lecky : XVIIIth Century, II, p. 2.

2 In the discussion that follows, I am greatly indebted to the able chapter by Hon. Mellen Chamberlain, in Winsor: Narrative and Critical History of America, VI, p. 1, etc. 
fifteenth century, by public law of all civilized nations, all unoccupied lands in newly discovered countries belonged to the Crown, under The approach whose anthority the discoveries had been can Revolumade. The English colonies were held by the lawyers to belong to the Crown and not to the people, and the Crown, in their view, had a right to govern or dispose of them without interference of Parliament. The colonists were not under parliamentary jurisdiction, but responsible only to the Kings; they possessed only such rights as their charters gave them; and these charters the Crown claimed the right to amend or revoke as it chose, though usually not without much discontent on the part of the colonists. James I amended the Virginia charter in 1624, and Charles II revoked that of Massachusetts in 1684, while William III gave to Massachusetts a new charter quite different in its provisions from its predecessor. Originally, these charters were simply incorporations of traling-companies, and when they were "perverted" into instruments of govermment, as the trating enterprises grew into the climension of States, the Kings eontinued to feel that they could do with the documents as they chose. The eolonists, claiming that they hard "the rights and privileges of Englishmen," among which was the right t" be free from arbitrary interferente, resisted the morldling of the princes: still, the pretensions of the

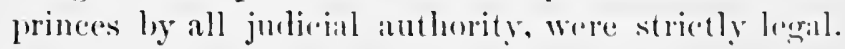
In the eye of the liaw, the colonists when disposed to resist were of a revolutionary temper.

The Kings elaimed the right to rile the colonims without parliamentary interferenee, hut ther were nut 
consistent. Charles II, for instance, allowed the parliamentary acts of Navigation, laws greatly

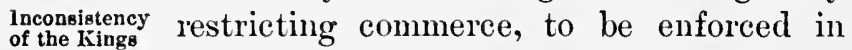
and the colo- the colonies; and in the time of William
nists. and Mary, colonial affairs were to a large extent transferred from the management of the Privy Council, the King's creation, to the Board of Trade, a council of commerce created by Parliament. Among the colonists, also, the general doctrine was that they owed allegiance to the King and not to Parliament: they received the Crown-appointed governor, and were accustomed to see the laws of their own assemblies sometimes set aside by royal authority; a memorable presentation of this doctrine, from the colonial point of view, was that made by Franklin, before the bar of the House of Commons at the time of the Stamp Act agitation in 1766. Still, the colonists were no more consistent here than the Kings. Story brings up the fact, that in 1757, the General Court of Massachusetts distinctly admitted the authority of Parliament; so, too, in 1761; and even so late as 1768, it was admitted " that his Majesty's high Court of Parliament is the supreme legislative power over the whole empire." I

The fact is, that, as regards the exact legal and constitutional status of the colonies, all were at sea, both in the colonies and at home. The Kings were uncertain, as appears from their consenting now and then to parliamentary interference. The colonists were uncertain, claiming now more, now less. In. the meantime, Parliament, become oligarchic and greatly invigorated during the decline of the royal

1 Story on the Constitution, Chap. XVI, § 188. 
prestige in the early Hanoverian days, assumed more and more power, taking upon itself at last jurisdiction over the colonies as a matter of course.

Harl there been only political misunderstandings, however, the colonies would never have been separated from the mother-country. In two The cccleslasother ways their love had become es- tical ance. tranged. First, as regards ecelesiastical matters, the destruction in Massachusetts through the new charter granted by William, of the "theocracy," socalled because it was a form of government in which only chureh-memhers were admitted to hold office or vote, was a severe shock to Puritan feeling. The grievance was kept alive through the toleration, enforced upon the Puritans, of all seets but Roman Catholies; as the eighteenth century advanced, the possibility of the introduction of a bishop and a ehureh establishment appeared, which eaused deepseated resentment. In Virginia, too, there was ecclesiastical trouble, but of a quite different sort. In Virginia, there was no hatred of Prelaey; her faith from the first. on the contrary, harl heen Episcopalian. Sion after the midlle of the eighteenth century. lawserer. there hat been intorference from England with the manner in which the clergy were paicl, - interferener causing muel exisperation, and which is best rememberent now as having given to Patrick Ifenry his tiost oppentmity. In the ethere

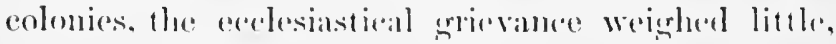

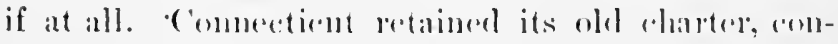
reniently hidelen in the hollew of and oak when a

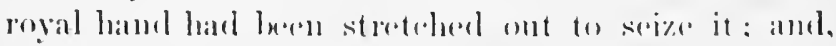

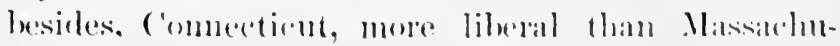


setts, had from the first given the franchise to the inhabitants in general, with no restriction of it to church-members. In New York, motley in faith as in population, the church question played but a small part in polities; while in Pennsylvania and Maryland, the terms of the grants to Penn and Lord Baltimore, respectively, had been more or less willingly acquiesced in by the proprietors and their tenantry from the first.

But a second stone of offence, which, unlike the ecclesiastical one, affected all America, existed in the The commer- trade regulations. Says Arthur Young: cial griesance. "Nothing can be more idle than to say that this set of men, or the other administration, or that great minister, occasioned the American war. It was not the Stamp Aet or the repeal of the Stamp Act; it was neither Lord Rockingham nor Lord North, but it was that baleful spirit of commerce that wished to govern great nations on the maxims of the counter." 1 It has been seen how powerful in England the mercantile class had become, a most excellent element, the growing influence of which marked the surrender by the world of worn-out mediævalism, and the taking on of the modern spirit. The mercantile class had been largely recruited by the new blood which had been poured into England, - Huguenot, Fleming, German, Hebrew. With the Whigs and the non-conformists, it threw its weight powerfully against the influence of the Tories and the Anglican Church, contributing much to the rejection of the doctrine of the divine right of Kings, and to the ascendency of Parliament. No good, however,

1 Quoted by Bancroft. 
is unmixed with evil: the spirit of commerce is often excessively selfish and capable of producing harm. In America, for in- Sthe spirit of stance, the English traders and manufacturers tried to subordinate colonial interests to their own, with ruthless disregard of the welfare of all but themselves. Soon after the middle of the seventeenth century began a series of enactments by Parliament, which were continued down to the outbreak of the American Revolution, - enactments designed to pour profit into pockets at home, at the expense of the population living in the dependencies. These were, first, the Navigation Laws, ${ }^{1}$ which weighed heavily upon the carrying-trade; and, second, the legislation brought about by the Board of Trade, an institution established with considerable powers in the time of William and Mary, to which were committed the interests of commerce and a general oversight of the colonies. Adam Smith was still in the far future, and the poliey constantly pursued was neither humane nor wise. We may judge of the temper of the Board from the fact that even John Locke, its wisest and one of its most influential members, solemnly arlvised William to appoint a captain-general over the colonies with dictatorial power; and the whole Board reeommended, in 1701, at resumption of the colonial eharters and the introduction of such "an ardministration of government as shall make them duly subservient to kingland."

1 See summary of them in Alam Smith: Weallh of Nations, 11, p. 201. In the account here given of the coming on of the Ameriean Revolution, the writer follows, with some molitioution, his life of sanuel Adaus, (American Statesmen Series, Fol. Xul, Chap. VI,) whith see for fuller detalls. 
The welfare of the colonies was systematically sacrificed to the aggrandizement of the gains of English manufacturers and merchants. Sometimes the provisions turned out to the advantage of the colonies: they were restricted to English markets, but they had a monopoly of those markets. More frequently there was oppression without any compensating good.

Restrictions, like the Act of 1719 , against the hat manufacture, designed for securing to the mothercountry a monopoly of the colonial trade, crushed out every industry that could compete with those of England. For such products as they were permitted to raise, the colonies had no lawful market but England, nor could they buy anywhere, except in England, the most important articles which they needed. With the French West India Islands a most profitable intercourse had sprung up, the colonists shipping thither lumber and provisions, and receiving in return sugar and molasses, the consumption of which latter article, in the widespread manufacture of rum, was very large. In 1733 was passed the famous "Sugar Act," the design of which was to help the British West The Sugar Indies at the expense of the Northern coloAct. nies, and by which trade with the French islands became generally unlawful, so that no legitimate source of supply remained open but the far less convenient English islands. The restrictions, indeed, were not and could not be enforced. Every sailor was a smuggler; every colonist knew more or less of illicit traffic or industry. The demoralization came to pass which always results when a community, even with good reason, is full of law-breakers, and the dis- 
position became constantly more and more unfriendly toward the mother-country.

The Board of Trade, however, the main source of the long series of aets by which the English dependeneies were systematically repressed, should receive execration not too severe. They simply were not in advance of their age. When, after 1688, the commercial spirit gained an ascendency quite new in England, the colonists, far off, little known, and despised, were pitehed upon as fair game, if they eould be made to yield advantage. In so using them, the men in power were only showing what has so often passed as patriotism, that mere expansion of selfishness, inconsistent with any broad Christian sentiment, which seeks wealth and might for the state at the expense of the world outside. It was inhumanity from which the world is rising, it may be hoped, for which it would be wrong to blame those men of the past too harshly. The injustice, however, as always, brought its penalty; and in this ease the penalty was the utter estrangement of the hearts of a million of Englishmen from the land they hat once loved, and the ultimate loss of a continent.

Before the settlements, it had been stipulated in the chartors that all the colonists were to have the rights and privileges of Englishmen, and

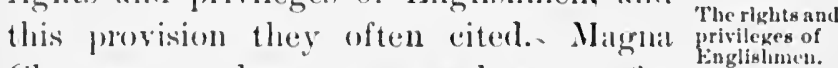
('hartal, ats we lave seen, was lut at confirmation of what haw stoed in and before the time of Edward the Confessor, - the primitive freedem, indeed, which hat prevailed in the German woods. This hat leeen again and agrain contirmed. Doenments of Edward I and Edward III, the Petition of 
Right of 1628, the Bill of Rights of 1689, had given such re-confirmation. The colonists all knew this in a general way. Especially the descendants of the twenty thousand Puritans knew it, who, coming over between 1620 and 1640, had been the seed from which sprang the race of New Englanders. They were to the full as intelligent in perceiving what were the rights of Englishmen, and as tenacious in upholding them, as any class that had remained in the old home. Left to themselves for sixty years, they little needed to assert their rights; but when at last interference began from across the water, it was met at the outset by protest. Parliament is a thousand leagues of stormy sea away from us, said they. That body cannot judge us well; most of all, our representatives have no place in it. We owe allegiance to the King, indeed; but instead of Parliament, our General Court shall tax and make laws for us. Such claims, often asserted, though overruled, were not laid aside, and at length, in 1766, we find Franklin asserting them as the opinion of America at the bar of the House of Commons. It cannot be said that New England was consistent here, as has been seen, but this was the general doctrine.

The sum and substance is that as to the constitutional rights of the colonists, the limits were, in particulars, quite undetermined, both in the minds of English statesmen, and also among the colonists themselves. What "the privileges and rights of Englishmen" were was not always clearly outlined, and the student finds sometimes more, sometimes less, insisted on, according as the temper toward the Old World is embittered or good-natured. As events progress, 
through fear of prelatical contrivings and through bad trade regulations, as has been seen, the tone becomes more and more exasperated. On the one side the spirit becomes constantly more independent; on the other side the claims take on a new shade of arrogance. When the first decided steps toward the Revolution oceur in 1764, in the agitations connected with the Stamp Act, the positionis in general of the parties in dispute may be set down as follows: "Parliament asserted the right to make laws to bind the colonies in all cases whatsoever; the colonies claimed that there should be no taxation without representation, and that, sinee they had no representatives in Parliament, they were beyond its jurisdiction."

The fall of Quebee in 1759 was an important crisis in the history of the colonists. They had learned to estimate their military strength more Effect of the highly than ever before. Side by side destruction with British regulars, they had fought power. against Montealm and proved their prowess. Officers qualified by the best experience to lead, and soldiers hardened by the roughest campaigning into veterans, abounded in all the towns. $A$ more independent spirit appeared, and this was greatly strengthened by the eiremustance that the destruction of the power of France suddenly put an end to the incubus which, from the foundation of things, had weighed nuon New England, viz. the dread of an invasion from the North. Coincident with this great invigoration of the tone of the colonies were eertain chinges in the English policy; changes which came aloont very naturally, but whieh, in the temper that harl begun to prevail, aroused fieree resentment. As the seven 
Years' War drew towards its close, it grew plain that England had incurred an enormous debt; her responsibilities, moreover, had largely increased. All India had fallen into her hands, as well as French America. At the expense of her defeated rival, her dominion was immensely expanding. Vast was the glory, but vast also was the care and the financial burden. A faithful, sharp-eyed minister, George Grenville, seeing well the needs of the hour, and searching as no predecessor had done into the corruptions and slacknesses of administration, at once fastened upon the unenforced revenue laws as a field where reform was needed. Industry on land, as we have seen, was badly hampered in a score of ways, and on the sea the wings of commeree were cruelly clipped.

Grenville's imprudence was as conspicuous as his eye was keen and his fidelity persistent. As the Enforcement first step in a series of financial measures of customs regulations. which should enable England to meet her enormous debt and her great expenses, he set in operation a vigorous exaction of neglected customs and imposts. The vessels of the navy on the American coast were commissioned to act in the service of the revenue, each officer becoming a customs official. At once all contraband trade was subjected to the most energetic attack, no respect being shown to places or persons. In particular, the Sugar Act, by which an effort had been made to cut off the interchange of American lumber and provisions for the sugar and molasses of the French West Indies, was strongly enforced, and the New England sailors, with the enterprising merchants of Boston, Newport, Salem, and Portsmouth behind them, flamed out into 
the fiercest resentment. Whereas for many a year the collectors, from their offices on the wharves, had winked placidly at the full eargoes from St. Domingo and St. Christopher, brought into port beneath their very eyes, now all was to be changed in a moment. Each sleepy tide-waiter suddenly became an Argus, and, backed up by a whole fleet-full of rough and ready helpers, proceeded to put an end to the most lucrative trade New England possessed.

To help forward this new activity in the carrying out of laws so often heretofore a dead letter, certain legal forms known as "writs of assistance" Writs of As. were recommended, to be granted by the sistance. Superior Court to the officers of the customs, giving them authority to search the houses of persons suspected of smuggling. The employment of such a power, though eontraband goods were often no doubt concealed in private houses, was regarded as a great outrage. Writs of assistance in England were legal and usual: if they are ever justifiable, English anthorities said then, and still say, they are justifiable under such circumstances as prevailed in America. All this was met by fierce resistance.

Inasmuch as the Ameriean colonies had profited especially from the suceesses of the war, it had been felt.justly enough that they should bear a portion of the burlen. It might have been possible to seeure from them a good sulsidy, but the plan devised for obtaining it was unwise. The prineiple was universally admitter that Parliament had power to levy "external" taxes, those intended for the regulation of commeree. With the Stamp Act, in The Stamp 1764, Grenville had taken a step farther. 
This was an "internal" tax, one levied directly for the purpose of raising a revenue, not for the regulation of commerce. The unconscious Grenville explained his scheme in an open, honest way. "I am not, however," said he to the colonial agents in London, "set upon this tax. If the Americans dislike it and prefer any other method, I shall be content. Write, therefore, to your several colonies, and if they choose any other mode, I shall be satisfied, provided the money be but raised." But Britain, pushing thus more earnestly than heretofore, found herself, much to her surprise, confronted by a stout and well-appointed combatant, not to be browbeaten or easily set aside.

No one was more astonished than Grenville that precisely now an opposition so decided should be called out. He had meant to soften his measures by certain palliatives. For the Southern colonies the raising of rice was favored; the timber trade and hemp and flax in the North received substantial encouragement; most important of all measures, the restrictions were taken from the American whalefishery even though it was quite certain under such conditions to ruin that of the British Isles. Grenville felt that he had proceeded prudently. He had asked advice of many Americans, who had made 110 objection to, and in some cases had approved, the Stamp Act. Men of the best opportunities for knowing the temper of the colonies, like Shirley, fifteen years governor of Massachusetts, and for a time commander-in-chief of all the military forces in America, had decidedly favored it. Nothing better than the Stamp Act had been suggested, though Grenville had 
invited suggestions as to substitutes. America, however, was in a ferment, and England, too, for one reason or another, was in a temper scarcely less threatening. Something must be done at once. But the responsibility was taken out of the hands of Grenville: a new ministry had come into power, and he was once more a simple member of Parliament.

The new premier was the Marquis of Rockingham, a young statesman of liberal prineiples and excellent sense, though with a strange incapacity for expressing himself, which made him a eipher in debate. The secretary of state, in whose department especially came the management of the colonies, was General Conway, a brave officer and admirable man, and well disposed toward America. On the 14th of January, 1765, began that debate, so memorable both on account of the magnitude of the issues involved, and the ability of the disputants who took larliament on part. A few Amerieans, Franklin and Act.

other colonial agents among them, listened breathlessly in the gallery, and transmitted to their comntry a broken, imperfeet rejort of all the superb forensic thunder. Whoever studies candidly the aecounts camnot avoid receiving a deep impression as to the power and substantial good purpose of the great speakers, and as to the grave embarrasinents that elogged then in striving to point ont a practiealbe eourse. The agitation ont of which pallimentary reform was to come was already in the air. While none of the actors in the scene appreciated the rlepth of the grulf into which England was sinking all evirlently felt the pressure of evil. Mansfield apleits ready at one point to admit abuse, but deprecates inter- 
ference with the constitution, while Pitt denounces the "rotten boroughs," and declares that they must be lopped off.

Edmund Burke made upon this occasion his maiden speech, but no one thought it worth while, in those Burke. days before systematic reporting had begun, to record the words of the unknown young man. Pitt, who followed him, hushed all into attention as he rose in his feebleness, his eloPitt. quence becoming more touching from the strange disease by which he was afflicted, and which he was accused of using purposely to increase the effect of his words; he first praised the effort of the new member, and then proceeded in that address so worthy of his fame. Pitt's advice was that the Stamp Act should be repealed absolutely and immediately, but at the same time that the sovereignty of England over the colonies should be asserted in the strongest possible terms, and be made to extend to every point of legislation, except that of taking their money without consent.

"There is an idea" in some that the colonies are virtually represented in this House. They never have been represented at all in. Parliament. I would fain know by whom an American is represented here. Is he represented by any knight-of-the-shire in any county of this kingdom? Would to God that respectable representation were augmented by a greater number! Or will you tell me that he is represented by any representative of a borough, a borough which perhaps no man ever saw? This is - what is called the rotten part of the constitution; it cannot endure the century. If it does not drop, 
it must be amputater. The idea of a virtual representation of Ameriea in this House is the most contemptible that ever entered into the head of a man. It does not deserve a serious refutation."

Later in the winter, when the debate was renewed in the House of Lords, Lord Canden, ehief justice of the Common Pleas, supported the views of Pitt in a strain which the latter called Camden.

divine. He tried to establish by a learned citation of precedents that the parts and estates of the realm had not been taxed until represented; lut as if he felt that abuses had accumulated, he declared that, if the right of the Americans to tax themselves could not be established in this way, it would be well to give it to them from prineiples of natural justice.-- Among those who replied, the most noteworthy was Lord Mansfield, chief justice of England, who declared, in opposition to Camden, that, -

"The doctrine of representation seemed ill-founded. There are twelve million people in Englind and Ireland who are not represented: the notion now taken up, that every sulject must be represented by deputy, is purely ideal. There an be no dombt, my lombl that the inhabitants of the colonies are as much represented in Parliament as the enreatest part of the people of England are represented, among nine mitlion of whom there are eight million who have no votes in elerting members of Parliament. Every objection. therefore, to the depenctency of the arotonies upon Parliament, which atrises to it npun the ground of representation. gores to the whold presont constitution of Great Britain, and I smppose it is not 
meant to new-model that too! A member of Parliament chosen by any borough represents not only the constituents and inhabitants of that particular place, but he represents the inhabitants of every other borough in Great Britain. He represents the city of London and all other the Commons of this land and inhabitants of all the colonies and dominions of Great Britain, and is in duty and conscience bound to take care of their interests."

When, after the speech of Mansfield, the subject came to a vote in the House of Lords, the matter stood in his favor by one hundred and twenty-five to five. In the Commons the majority on the same side was as overwhelming.

Looking back upon this momentous debate after a century and a quarter has elapsed, what are we to The question say as to the merits of it? England has summed up. completely changed since then her colonial policy, but no sober second thought has induced her historians to believe that the position of the government was plainly a wrong one. Pitt and Camden turned the scale for us in the Stamp Act matter: their declarations put backbone into the colonial resistance, and disheartened the ministry in England; but Pitt's opinions were declared at the time to be peculiar to himself and Lord Camden, and have ever since, in England, been treated as untenable." Mansfield's theory of "virtual representation," - that a representative represents the whole realm, not merely his own constituency, "all other the Commons of this land, and the inhabitants of all the colonies and dominions of Great Britain, and is in duty and con-

1 Massey: History of Reign of George III, I, p. 262. 
science bound to take care of their interests," - is declared by another writer to be grandly true, though, to be sure, somewhat oyerstrained as regards the colonies. Burke, a few years afterwards, addressing the electors of Bristol, developed the doetrine elaborately. Mansfield was right in urging that the constitution knows no limitation of the power of Parliament, and no distinction between the power of taxation and other kinds of legislation. The alstract right, eontinues our historian, was unquestionably on the side of the minister and Parliament who had imposed the tax, and that right is still acted upon. In 1868, in the trial of Governor Eyre of Jamaiea, the English Judge Blackburn decided "although the general rule is that the legislative assembly has the sole right of imposing taxes in the colmy, yet when the imperial legislature chooses to impose taxes, aceording to the rule of English law they lave a right to do it." I Lecky says :-

"It was the first prineiple of the constitution, that a member of I'arliament was the representative not merely of his own constitneney, lut also of the whole empire. Man connected with, or at least specially interested in the colonies, always found their way into Parliament; and the very fact that the colonial arguments were maintained with transcendent power within its walls was sufficient to show that the colonies were virtually represented."

Lecky, however, even while thus arguing, admits that the Stamp Act did munestionalyy inf ringe npon a great principle; and he acknowledges that the doetrine, that taxation and representation are inseparably

1 Yonge: Constilutional History of Fuglant, p. ixi. 
connected, lies at the very root of the English conception of political liberty. It was only by straining matters that the colonies could be said to be virtually represented, and in resisting the Stamp Act the principle involved was the same as that which led Hampden to refuse to pay the ship-money. ${ }^{1}$

It is only fair for the present generation of Americans to weigh arguments like those of Mansfield, and to understand how involved the case was. 'The statesmen of the time of George III. were neither simpletons nor utterly ruthless oppressors. They were men of fair purposes and sometimes of great abilities, not before their age in knowledge of national economy and political science; still, however, sincerely loving English freedom, and, with such light as they had, striving to rule in a proper manner the great realm which was given to them to be guided. In ways which the wisest of them did not fully appreciate, the constitution had undergone deterioration through the carelessness of the people and the arbitrary course on the part of the ministers; and it is a mark of greatness in Camden, that, learned lawyer though he was, he felt disposed to rest the cause of the colonies on the basis of "natural justice," rather than upon the technicalities with which it was his province to deal. In the shock of the Stamp Act and Wilkes agitations England came to herself, and by going back to the primeval principles, started on a course of reform by no means yet complete. At that very time Richard Bland of Virginia, anticipating by a century the spirit and methods of the constitutional writers, of whom E. A. Freeman and 
Bishop Stubbs are the best-known examples, uttered sentences which might well have been taken as their motto by the "Friends of the People," the "Society of the Bill of Rights," and the other organizations in England which just now or soon after began to be active for the salvation of their country. He deriver the English constitution from Anglo-Saxon principles of the most perfect equality, which invested every freeman with a right to vote.

"If nine-tenths of the people of Britain are deprived of the high privilege of being electors, it would be a work worthy of the best patriotie spirits of the nation to restore the constitution to its pristine perfection." 1

Much as Pitt and Camden were admired, and powerful as was their brave demuneiation of the Stamp Act and their demand for its repeal, their famous position that $a$ distinction must be made between taxation and legislation, and that while Parliament could not tax, it could legislate, seemed no more tenable to Amerieans than it did to Englishmen. The colonial leaters, following. no doubt uneonseiously, the precerlent of the thirteenth century, soon passed on from demanding representation as a condition of taxation, to demanding representation as a condition of legislation of every kind ; they denied utterly the power of Panlianent to interfere in any of their affairs; they owed allegiance to the King, hut of Parliament they were completely independent. So Fanklin hat already declased. This position was shocking to l'itt, and he would have bech ats willing to suppress its upholders as was Lord North himself. It is making no arrogrant claim to sily that in all 
this preliminary controversy the American leaders

Superior appreciation by American Anglo.saxon freedom. statesmen of show a much better appreciation of the principles of Anglo-Saxon liberty, and a management much more statesmanlike, than even the best men across the water. It was to be expected. "Political power was incomparably more diffused; the representative system incomparably less corrupt than at home." I As far as New England is concerned, there is no denying the oft-quoted assertion of Stoughton, that God sifted a whole nation to procure the seed out of which the people was to be developed. The colonists were picked men and women, and the circumstances under which they were placed at their arrival on these shores forced upon them a revival of institutions which in England had long been overlaid. 'The popular moot had reappeared in all its old vigor, and wrought in the society its natural beneficent effect. Together with intelligence and self-reliance in every direction, it had especially trained in the people the political sense. In utter blindness the Englishman of our revolutionary period looked down upon the colonist as wanting in reason and courage. Really the colonist was a superior being, both as compared with the ordinary British citizen and with the noble. Originally of the best English strain, a century and a half of training, under the institution best adapted of all human institutions to quicken manhood, had had its effect. What influence had surrounded lord and commoner across the water to develop in them a capacity to cope with the child of the Puritan, schooled thoroughly in the town-meeting :

I Lecky: XVIIIth Century, III, p. 296. 
The discontent was most marked in Massachusetts. Comnecticut, Rhode Island, and New Hampshire, closely connected, took their tone from her. In New York was a party prepared to go all lengths with the most strenuous, step for step; there was a party, too, better placed as regards wealth and position, - the rich merchants, the Episcopalians generally, the holders of the great feudal estates, the Dutch farmers, and recent German settlers, - who were either actively loyal to the Crown or quite apathetic. In Pennsylvania, there were strong opposers of the English policy, whose learling representative, now that Franklin was absent in England, was Joln Dickinson, very famous through the "Farmer"s Letters," well-reasoned papers in which was given a popular explanation of the unconstitutionality of government acts: the powerful sect of Quakes, however, as the troulle rleepened, set themselves against resistance to the powers that were; and the Germans felt little interest. Passing to the Soutl, Virginia was all alive. The aristocrary of great tobacen-planters, who held the power, full of vigor and trained to struggle in the longreontinned disputes with different royal governors, stood most stubbornly against British eneroaroment. The aolony was far enough from demoerary : the large elass of poor landless whites had scareely more interest in polities than the slaves; hut the IIouse of Bingesses understond well the chumpiomship of Ameriom priv-

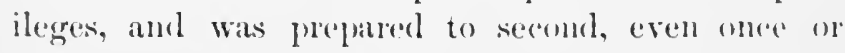
twice to anticipate, Massarelusetts in measures of opposition. Influenced in the arly daty hy latrick

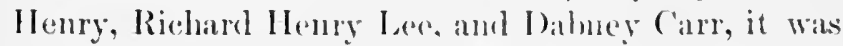
sometimes in advance of the Northern province, and 
a little later, when Washington, Jefferson, and Madison came forward, it stood certainly foremost. In South Carolina, too, was a party headed by Christopher Gadsden, prepared to take the advanced ground.

In the preliminary years, however, Massachusetts was very plainly before all others, according to the Leadership of view both of America and England. If Massachu-
setts.

in taking a bold step, it was perhaps due to the management of the skilful Massachusetts statesmen, who, for reasons of policy, held in check their own assembly, that local pride elsewhere might be conciliated, and America, generally, be brought to present an unbroken front.

\section{Discontent with England became rife in New}

1 On this point, which local pride might dispute, a few authorities may be cited. Englishmen at the time felt as follows: "In all the late American disturbances, and in every thought against the authority of the British Parliament, the people of Massachusetts Bay have taken the lead. Every new move towards independence has been theirs; and in every fresh mode of resistance against the law they have first set the example, and then issued out admonitory letters to the other colonies to follow it." - Mauduit's Short View of the New England Colonies, p.5. See, also, Anburey's Travels, I, p. 310. Hutchinson : History of Massachusetts Bay, III, p. 257. Rivington: Independence the Object of Congress in America, London, 1766, p.15. Lord Camden called Massachusetts "the ring-leading colony." Coming to writers of our own time, Lecky declares, History of the Eighteenth Century, III, p. 386: “The central and southern colonies long hesitated to follow New England. Massachusetts liad thrown herself with fierce energy into the conflict, and soon drew the other provinces in her wake." Says J. R. Seeley : Expansion of England, pp. 154, 155: "The spirit driving the colonies to separation from England, a principle attracting and conglobing them into a new union among themselves, - how early did this spirit show itself in the New England colonies! It was not present in all the colonies. It was not present in Virginia; but when the colonial discontents burst into a flame, then was the moment when Virginia went over to New England, and the spirit of the Pilgrim Fathers found the power to turn the offended colonists into a new nation." 
England and Virginia before it appeared elsewhere in America. The oppressive trade regulations bore upon manufactures and commerce; and since most of the manufactures were in New England, and the principal artieles of export were New England timber and Virginia tobacco, those colonies first became exasperated. The Stamp Act, however, bore upon all, and from 1i6t the backward colonies began to show the same wrathful temper. To preserve strict truth, the historian must not omit to state that a certain discreditable reason had its part in bringing about American resistance, as well as the just indignation at the selfish and arbitrary policy which ground the country down. A debt of eight or nine million pounds was owed to British merchants. and this debt, so some thought, in case of successful revolt, it might be possible to repudiate. ${ }^{1}$

I Jadison's View, XI, and Boucher, quoted by Chamberlain, "John Adams, the Statesman of the Revolution," p. 3i. 


\section{CHAPTER XIV.}

THE AMERICAN REVOLUTION A STRUGGLE OF PARTIES, NOT COUNTRIES.

1776-1783.

THE condition of things in the middle of the eighteenth century has been sufficiently set forth. Character of George III had been educated carefully George III. under the influence of his mother, a woman, who, like the members of German royal families at that time universally, exaggerated to the highest degree the prerogatives of the King. Her constant exhortation, "George, be a King," is said to have influenced her son much. Jacobitism had been utterly quenched in 1745. No other prince since Charles II had been hailed with such acclamation as George III, when he took his seat. Whereas the prestige of the Kings had been declining, prerogative and the jus divinum now began to be fashionable again. The Tories were in power, and the great Jacobite families, giving up at last the cause of the Stuarts, rallied round the Hanoverian prince, retaining all their old anti-popular ideas. George was fairly sensible, thoroughly brave, well-meaning, and sincerely anxious to bring about good for England, not postponing the interests of his kingdom, as his two predecessors liad done, to those of his German electorate. He was, 
however, ignorant, narrow-minded, and arbitrary, and was determined to make himself as absolute as the Kings of Europe in general. He hesitated at no corruption, though he was himself honest, and by means of the "King's Friends," a great body in Parliament whom he won to himself by bribes, he grew very powerful.

It is not right, however, to regard George III as a fair representative of the England of his time, nor to think that in the great war of the Ameriean Revolution, of which on the British $\begin{gathered}\text { Sympathy of } \\ \text { Englishmen }\end{gathered}$ side he was the central figure, Americans American were really fighting England. Says a modstruggle. ern English authority: ${ }^{1}$ "Of course, Americans regard independence as their great achievement. In this they are quite right. When, however, they proceed to regard independence as a victory gained over England, their enemy, they are surely egregiously in error. . . . At the time the United States were fighting for independenee, England was fighting for her liberties: the common enemy was the Hanoverian George III and his Germanized Court. ... When the news was brought to London that the Cnited States had apr pealed to arms, William Pitt, an Englishman, if there ever was one, rose in his seat in Parliament, and with mplifted voice thanked Gind that the Anerican colonists retained enough of English bloonl to tight for their riglits. Sine Englishmen out of every ten ontside of court influence similarly rejoiced. Indepenulence day is as much a red-letter day for every gromine kinglishman as for every genume Ameriean. And so it should le: Wrathingtom hat trod in the footsteps

1 Westminster leview, Marrh, 1Ks!! 
of Hampden ; his task was easier than that of Hampden, and the solution he wrought, which an interval of three thousand miles of ocean practically dictated, was more thorough." The writer laments the estrangement of Americans from England. " England's sternest, coldest, most critical censors, I have found among descendants of the old settlers; surely those retain something of ancient Puritan bitterness. The source of estrangement I am inclined to trace largely to the fact that the average American reads no history but United States history, and that he can scarcely be said to study."

Vast misapprehension as to the true character of the American Revolution no doubt prevails: the English Radical whose words have been A strife on A both sides of quoted puts the case none too strongly.
the ocean.

A high American authority ${ }^{1}$ declares that the American Revolution was not a quarrel between two peoples, but a strife between two parties in one people, Conservatives and Liberals. These parties existed in both countries; the battle between them took place not only on the fields of America, but in the British Parliament also, some of the fiercest engagements in the latter arena. The strife took place on both sides of the water with nearly equal step, and was essentially the same on both sides; so that if, at the close of the French War, all the people of Great Britain had been transported to America, and all the people of America to Great Britain, and put in control of British affairs, the American Revolution and the contemporary British Revolution might

1 Hon. Mellen Chamberlain, in Winsor : Narrative and Critical History of America, VI, Chap. I. 
have gone on just the same, and with the same final result. For a long time both peoples had had a common history; but in the reaction at the Restoration, the British race in England passed again under the power of prerogative, exchanging it in 1688 for the domination of a Parliament representing only the rich and high-placed, - by no means the mass of the nation. In Great Britain, therefore, the struggle was to recover what had been lost. The emigrants to New England, on the eontrary, left behind institutions which were monarehical, both in Chureh and State, and revived ancient institutions which were democratie. They fought, therefore, to preserve what had been retained, not to recover what had been lost, and drew with them into the eontest the rest of America.

This view of the character of our Revolutionary War is so unfamiliar that it is worth while to ilhustrate it with some fulness. As to the embarrassments which the King and his number of ministers unterwent from a powerful opallvocites.

position, in their attempits to coerce Americal, the latest historian of the eighteenth century makes ont a strong ease. From the first, the immense influenee of Pitt, soon to be liarl of Chatham, the'n the most powerful of sulgjects, was on the side of . Imericia. We have secu him justify, with all his eloymenen,

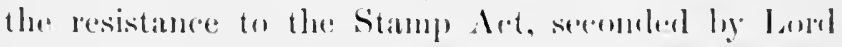
Camden, whe also hatd great influernere. At the time of the tea duty, there was in l'alliament at strung seetion supporting the Anericans, and contside of l'arliament a still more democratic party who kopt the country in alarm through fierce politicat agitation; 
all which, as was truly said by Lord North, lured on America and blocked the efforts of the ministry. ${ }^{1}$ To be sure, the opposition were divided among themselves. Dean Tucker and Adam Smith favored letting the colonies go. ${ }^{2}$ Burke and Chatham, on the other hand, wished to retain them, but insisted upon a repeal of all coercive and aggressive laws. Again, Chatham always maintained that the American cause was essentially that of the Whigs. No taxation without representation "is the common cause of the Whigs on the other side of the Atlantic and on this"; he extolled the Americans as " Whigs in principle and heroes in conduct," and openly wished them success. Others of that party, however, like Grenville, declared that the American cause was anti-IVhig, ${ }^{3}$ because, refusing the jurisdiction of Parliament, its supporters sought to extend the power of the King. It must be admitted that some of the ammunition of the American champions was drawn from Tory arsenals, and this circumstance naturally tended to alienate from them Whigs who were strict conFear for Eng. structionists. The difference tended to lish liberty if
Americawere disappear as the contest proceeded: the conquered. Whigs generally became pro-American, fearing that the conquest of those with whom they sympathized in America would also establish absolutism in England, - an opinion expressed by. Chatham, Fox, Horace Walpole, and Burke.

Nor were the IVhigs ever in full sympathy with Pusition of the Radicals. English Radicalism was born Burke. in 1769 , in the time of the Wilkes disturb-

1 Lecky : XVIIIth Century, III, pp. 403, 404.

${ }^{3}$ Ibicl., p. 587 .
2 Ibid., p. 421, etc.

4 Ibid., pp. 589, 590. 
anees. Then began the agitation for parliamentary reform, - a matter whieh the Whigs took up but slowly, differing among themselves. Burke, for instance, though he taught the fundamental Whig doetrine, that Sovereign, Lords, and Commons must be regarded as trustees of the people, and although he advoeated the publication of the diseussions of Parliament and other advanced measures, was yet stubbornly against "levelling doetrines," opposing all attempts to lower the suffrage, to abolish rotten boroughs, to add to shire-representation, to modify in any way the framework of Parliament. "The machine is well enough to answer any good purpose, provided the materials were sound." And again: "Our representation is as nearly perfeet as the neeessary imperfeetion of human affairs and of human creatures will suffer it to be." 1 As to parliamentary reform, he was in opposition to the elder and the younger litt, both of whom favored it, and he was far away on many points from the "Society of the Supporters of the Bill of Rights," who demanded thorough govermment of, by, and for the people. In opposing, as he rlicl later in life, the French Revolution, he only carried out his earlier principles. The Radicals had no friendship for him. Mr. Macanlay, their ablest writer, said of his "Thonghts on the Cause of the Present I)isenitents," that it contained "a poison suffieient to destroy all the little virtue and understanding of somnd policy left in the nation: and that it was peenliarly fitted to divert the mation from organic and truly useful reforms to a revival of aristoeratic faetion." 2

1 Lecky : XVIIIh Century, III, p. 22:.

2 Ibill., p. 224. 
But for these dissensions in the opposition, the King and his party, energetic though they were, could scarcely have taken a step. The opposition grew to be very formidable in spite of the want of union. Though the anti-American majority in Parliament in 1774 was heavy, the American cause was powerfully upheld, and there was reason to believe that if the masses were counted, England was for

The masses pro-Amerithe rebels. Common people held the war can. in abhorrence. So, too, the manufacturers and traders : these often were actuated by a selfish motive, for the war disturbed business; and yet it was mainly the demands of the commercial class which had brought the war about. Non-conformists were steadily and zealously pro-American. Dr. Price, a great light among them, expressed American ideas in his "Essay on Liberty," and was only restrained by ill-health from going to America to manage the finances. In another sphere, the tried and skilful soldiers, Amherst, Conway, and Barre, did not conceal their sympathy. Fox eulogized Montgomery, slain at Quebec, in the House of Commons; while the Duke of Richmond said in the House of Lords, after Bunker Hill, that the Americans were not in rebellion, but resisting acts of the most unexampled eruelty and oppression. This remarkable nobleman, who had gone in 1776 to France to claim an old French peerage, wrote from Paris to Burke, that the political condition of England was one reason why he wished to claim the French peerage. He believed England to be on the verge of a despotism more oppressive than that of France, for it would be less tempered by habit and manners. $\mathrm{He}$ 
limself was likely to be proscribed, and in that case, "if America be not open to receive us, France is some retreat, and a peerage here is something." The gleeful exclamation of Horace Walpole, in the following year, over the surrender of Burgoyne, and the declaration of his belief that the Americans were better Englishmen than the English themselves, has already been quoted. ${ }^{2}$ In the House of Commons, the American army was spoken of as "our army." William Pitt, in 1781, called the attempt to reduce America, "most accursed, wicked, barbarous, eruel, unnatural, diabolical." In the ruling elass, a minority containing personages of the highest rank and the ablest men in the nation had irlentified itself eompletely with the insurgents. They resisted with passion; for they came to feel - a feeling which modern writers declared thoroughly justified - that the defeat of the Americans would probably be followed by a subversion of the constitution of England. ${ }^{3}$ Meantime, among the people, the war was to the last degree unpopular. London was sometimes at the merey of mobs; the army could be maintained only by press-gangs, by emptying into the reginents the prisons, and by buying Hessians.

If the King and his ministers were cmbarrassed by an opposition, the Ameriean patriots were no less embarmasserl. An energetic minority, in fact, lought to pass the Revolution. Firengry of

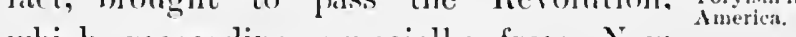
which proceeding especially from New England, was carried thromgh in spite of a majority

1 Burke's Correspontence, H, IN. 112-1:0; in lecky, III, p. 5:3.

${ }^{2}$ p. 110. $\quad 3$ liuckle : History of Civilization, I, fr. :H5, Anerican ed. 
in the colonies, - a majority in great part quite apathetic, but to some extent actively resisting. ${ }^{1}$ Washington feared in 1776 that if his army were unsuccessful, the enemy would recruit faster than the patriots. The British government were sanguine as to help from loyalists, and sent out at one time equipments for eight thousand men, who, it was thought, could easily be raised among its friends. Large bodies in America were dragged into the war with extreme reluctance. Many rich Southem planters opposed; while the Pennsylvania Quakers were so recalcitrant as to draw upon themselves from stalwart Samuel Adams, the "Father of the Revolution," the charge of being "puling, pusillanimous cowards." In New York, two-thirds of the property was in loyalist hands; and, indeed, outside the city there was no serious disaffection in the colony. Galloway, a Tory active in the Congress of $\mathbf{1 7 7 4}$, who afterwards went to England, said before the House of Commons that only one-fourth of the soldiers in arms were really Americans. This, of course, was an exaggeration, but there is no doubt that ultimately recruits to the "Continentals" were in great part recently arrived Irish and Scotch immigrants. The Irish, in particular, both Catholic and Protestant, sustained the American cause, while many Scotch were Tories. ${ }^{2}$ In 1780 , the force of the Revolution was so far spent, and the opposition so powerful, that the patriot cause was completely dependent upon France. The emigration of Tories, when the day was at last won, was

1 Lecky: XVIIIth Century, III, p. 458, etc.

2 Ramsay : History of American Revolution, Appendix, No. IV. Dublin, 1795. 
relatively as great as that of the Huguenots after the Revocation of the Ellict of Nantes. The total number is estimated to have been at least one hundred thousind.' In this multitude were comprised only such, with their families, as had been active for the King. The indifferent, who had lent no helping hand to the patriots, must have been a multitude much larger; these remained behind, inertly submitting to the new order of things, as they lad swayed inertly this way or that, following the power and direction of the blast of war.

Nor were the Tories only important beause they were numerous. They were generally of a character that made their resistance most effeetive. ${ }^{2}$ "History, at this late date, can certainly afford a compassionate word for the Tories,

IIigh position and character of the 'Tories. who, besides having been forced to atone in life for the mistake of taking the wrong side, by undergoing exile and confiscation, have received while in their graves little but detestation. At the evacuation of Boston, says Mr. Sabine in the 'American Loyalists,' eleven humdred loyalists retired to Nova Scotia with the British army, of whom one hundred and two were men in official station, eighteen were clergymen, two humbed and thirteen were merchants and traders of Bostom, three hundred and eighty-two were farmers and mechanies, in great part from the comntry. The mere mention of calling and station in the case of the forlorn, expatriated company conveys a suggestion of respectability. Just an mumerous

1 Lecky : XVIIth Century, IV, ]. 285.

2 A passage here is takıll from the writer's "Samuel Alams," ("hap. $\mathrm{XVII}$, which see for a fuller cousideration of the subject. 
and respectable were the exiles in the other colonies. There were, in fact, no better men or women in America, as regards intelligence, substantial good purpose, and piety. They had made the one great mistake of conceding a supremacy over themselves to distant arbitrary masters, which a population nurtured under the influence of the revived folkmoot ought by no means to have made; but with this exception, the exiles were not at all inferior in worth of every kind to those who drove them forth. The Tories were generally people of substance; their stake in the country was greater even than that of their opponents; their patriotism, no doubt, was to the full as fervent. There is much that is melancholy, of which the world knows but little, connected with their expulsion from the land they sincercly loved. The estates of the Tories were among the fairest; their stately mansions stood on the sightliest hill-brows; the richest and best tilled meadows were their farms; the long avenue, the broad lawn, the trim hedge about the garden, servants, plate, pictures, - the varied circumstance, external and internal, of dignified and generous housekeeping, - for the most part these things were at the homes of Tories. They loved beauty, dignity, and refinement. It seemed to belong to such forms of life to be generously loyal to King and Parliament, without questioning too narrowly as to rights and taxes. The rude contacts of the town-meetings were full of things to offend the taste of a gentleman. The Crown officials were courteous, well-born, congenial, having behind them the far-away nobles and the Sovereign, who rose in the imagination, 
unknown and at a distance as they were, surrounded by a brilliant glamour. Was there not a eertain meanness in haggling as to the tax which these polite placemen and their superiors might ehoose to exact, or inquiring narrowly as to their eredentials when they ehose to exereise authority? The graeeful, the chivalrous, the poetic, the spirits over whom these feelings had power, were sure to be Tories. Demoeracy was something rough and coarse; independence, - what was it but a severing of those conneetions of which a colonist ought to be proudest: It was an easy thing to be led into taking sides against notions like these. Fience, when the country rose, many a high-bred, honorable gentleman turned the key in his door, drove down his line of trees with his refined dame and carefully guarded children at his side, turned his back on his handsome estate, and put himself under the shelter of the proud banner of St. George. It was a mere temporary refuge, he thought, and as he pronouneed upon "Sam Adams" and the rabble a gentlemanly execration, he promised himself a speedy return, when discipline and loyalty should have put down the ship-yard men and the misled rustics.

"But the return was never to be. The day went against them; they crowded into ships with the gates of their country barred forever behind them. 'They found themselves pemniless upon shores often bleak and harren.

Pathetic circumstances of their cxpatriation. always showing seant hospitality to outcasts who came empty-handed, and there they were fored to begin life anew. Having chosen their side, their lot was inevitable. Nor are the vietors to be hashly 
judged. There was no umnecessary cruelty shown to the loyalists. The land they had left belonged to the new order of things, and, good men and women though they were, there was nothing for them, and justly so, but to bear their expatriation and poverty with such fortitude as they could find. Gray, Clarke, Erving, and Fanenil, Royall and Vassall, Fayerweather and Leonard and Sewall, families of honorable note, bound in with all that was best in the life of the Province, who now can think of their destiny without pity?"

The war of the American Revolution, then, was a strife not of countries, but of parties, - a strife carried Victory of the on both in England and in America, -
popular party popular party
on both sides
of the Altan. of the Atlan- dependency, - but, nevertheless, a strife
tic. ic. carried on in each arena for the preservation of the same priceless treasure, - Anglo-Saxon freedom, and fought through with similar spirit. On one side of the Atlantic, victory came speedily. In America there were no traditions and institutions, rooted for centuries, to be upturned; and besides, there came most timely help from France. WV are to see, however, how victory in America drew necessarily with it victory in England. It has long been delayed, but it has been steadily coming, until at the present moment, as regards popular freedom, the two countries stand nearly together, - England, perhaps, though preserving monarchical forms, and much social feudalism, really in advance. Popular freedom was probably saved to England by the success 
of the American struggle; ${ }^{1}$ and, on the other hand, America has derived that popular freedom nowhere but from the mother-land, through the struggles of her Alfred, of her Langton and the Barons of 1215 , of her Earl Simon, of her knights-of-the-shire, her Ironsides, her supporters of the Bill of Rights. What a noble community is this, - common striving so heroie for a common cause of such supreme monent! How men the nursing of petty prejudiee between lands so linked; how powerful the motive to join hand with hand and heart with heart:

${ }^{1}$ Lecky: XVIIth Century, III, p. 289; see also Buckle, as before cited, p. 225 . 


\section{CHAPTER XV.}

THE CONSTITUTION OF THE UNITED STATES.

1783-1789.

Whes the war of the American Revolution had been brought to a successful issue, and the Thirteen The written Colonies stood independent, as United Constitution a
unique feat- States, the momentous question at once ure of the American polity. was presented, What shall be the form of the new nation? The adoption of the Federal Constitution was the next step taken. The only unique feature of the American polity, as the new nation took shape, was the provision as regards each separate State and as regards the United States, for a carefully formulated instrument, to be drawn up by an assembly of representatives of the people distinct from the legislative assembly, - an instrument to be interpreted by a Supreme Court especially empowered for that purpose, - an instrument, by which the whole work of law-making shall be imperatively controlled. No such controlling instrument In England, has guided the development of Great Parliament
completely Britain, or of any other land. De Tocqueunfetterced. ville declared that in Great Britain the constitution can change without cessation, or rather it does not exist. The English law-makers are completely unfettered. English writers, such as Black- 
stone, and his ablest commentator Christian, ${ }^{1}$ make similar statements. In a former time, indeed, one may find in law-writers the idea that there are fundamental prineiples superior to Kings and Parliaments; but the modern doctrine is that of the absolute supremaey of Parliament. Jeremy Bentham proelaimed that nothing was superior to legislation, and that is the theory of torlay. The "Written," or as Mr. Bryce ealls it, the "Rigid," Constitution, as part of the polity of a people, appears for the first time in Ameriea. It is the most distinetive feature of our system, and, moreover, that probably which has the most value.

"We have not yet," says Dr. W. G. Hammond, "fully learned the vast importance and momentous eonsequences of the new element that has been introduced into the been introduced into the science of govern- the written ment by . . . the recognition of two distinct and unequal grades of law (even though both derive their anthority from the same supreme power, the people), one of which always eontrols and limits the other, and cannot he ehanged or limited by it or by any other of the ordinary processes of le gislation; and eonserguent upon this the securing of the funditmental maxims of the government and its main features, against attacks of the persons in anthority, while they are gort conduwerl with the powers necessary for the combluet of affair." 2 The Fathers put ats many obstacles ats they comld rontrive, als Lowroll fhrases it, "not in the way of the proplen's will, but of their whim"; above all is the ligingl constitution, a bridle unu jopular whim. By this the penple

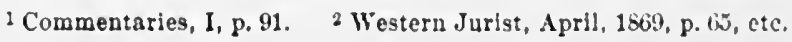


have shorn themselves of a measure of their power, making themselves safe from themselves, and thus is imparted to the government the highest practicable and desirable stability.

Although in its developed form the idea of a Rigid Constitution does not appear until the establishment History of the of America, the beginnings of the notion idea. must be sought for earlier. A germ of the idea may possibly be found in Magna Charta; still another, in the charters by which the guilds of the Middle Ages were constituted. ${ }^{1}$ Each corporation found its grant of privileges accompanied by a code of obligations, to which it was forced to conform under penalty of losing those privileges. The English settlement of America was made by great trading corporations, the charters of which, originally nothing more than grants to mercantile companies, made in true mediæval fashion, when "perverted" into instruments of government, stood behind the colonial assemblies, like the constitutions behind the legislatures, State and Federal, of the American Union.

It is, however, in the idea of an American Constitution that it shall come from the people themselves, It must come who are to be bound by it. In the case of from the peo- the charters mentioned, some outside au-
ple thempelves. thority, King, or over-lord of lower rank, imposes the limitation. Whence comes this noble element of self-restriction? In the Social Compact on board the "Mayflower"; the agreement of the Rhode Island settlers in 1637; and of the Connecticut towns, Hartford, Wethersfield, and Windsor, a year or two later, the freemen bind themselves. In the time of

1 Brooks Adams : Atlantic Monthly, November, 1884. 
the English Commonwealth, Vane in the "Healing Question," in 1656, elearly outlines what has become the American form of a constitutional convention, and urges Cromwell to call one for the settlement of the "fundamentals," instead of pursuing an arbitrary course. Cromwell took no notice of Vane's suggestion; though the idea was in the minds of men, no great people undertook to put it in practice until after another century had passed. When at the throwing off of the royal clominion, the charters under which the 'Thirteen Colonies hald existed lost authority, the people in the several states mate provision for the new order of things, continuing generally the old charters with little change, as the most convenient scheme that could be devised. When, therefore, in 1787 , the fathers gathered in convention at Philartelphia for their memorable work, sent by the will of the people, the proceeding was not without precedent, thongh the s'ale on which the experiment was to be made was latrger than ever before.

Thongh the illea of formulating for a new State a Rigicl ('onstitution by means of a convention of popular delegates was something novel, the careful relen. there Wats, as regands the Constitution lion of Eng. itself., when it at last appeatred, singularly conventon of little that was original. "The Fathers,"

says Bryce." "had neither the rashess nor the capacity necessary for constructing a constitution " fmiori: there is womlerfully little gemuine inventiveness in the world, least of all in the ficlel of political institutions. 'They followed mothods whinh experi-

1 A summary of the Fenleral (onstlulion is given in Appendix I).

- Ameriean Commonwealth, Vol. 1. p. \$1, American ed. 
ence had tested, - their own colonial governments, of late transformed into State governments." These had a general resemblance to the British constitution, and in so far, it may with truth be said that the British constitution became the model for the new national government. The claim made by Sir Henry Maine ${ }^{1}$ is not at all extravagant, that the Constitution of the United States is colored throughout by ideas of British origin ; is, in fact, a version of the British constitution as it must have presented itself to an

Contrast between constitution-makers in Ameriea and elsewhere.

observer in the second half of the last century. A most significant contrast is to be noticed between the work of the constitution-makers of the incipient United States, and that of the constitution-makers of other countries, both in Europe and America, which within a hundred years have undertaken a reconstruction of their respective governments. In the case of the latter, the re-shaping has generally been done in a temper of bitter dissatisfaction with the old institutions, and with an earnest determination to build anew from the foundation, cutting loose completely from the past. So it has been in Mexico and the South American Republics, founded upon the ancient dependencies of Spain; so it has been in the case of Spain herself; so, to a most marked degree, it has been in the case of France. In the United States, however, the people at the outset were more than satisfied with the bulk of their institutions, and adopted them without change, for the new order. "All sorts of old English institutions," says Bryce, "have been transferred bodily, and sometimes look as odd in the midst of their new sur-

1 Popular Government, Essay IV, Constitution of the United States, 
roundings as the quaint gables of a seventeenth century house among the terraces of a growing London suburb." 1

As to local divisions and administration, everything went forward in the different parts of the country without break. The towns of New Englind, governed each by its town-meeting, $\begin{aligned} & \text { Lucal forms } \\ & \text { quile un. } \\ & \text { changed. }\end{aligned}$ a resuscitation, as we have seen, of a very ancient order, persisted in full vigor. In the South, the parishes, each governed by its vestry, and possessing a civil as well as ecelesiastical jurisdiction, all carefully modelled after the English parish of the seventeenth century, were continued without interruption. - As to eounty government, its centre continued to be the County Court. Justices, sheriff, constable, coroner, - the functionaries, continued under the old names: the forms of proeedure mulerwent no alteration; the traditions persisted, even to the old French "Oyez, oyez!" with which the crier called the court to order. As to the retention of this scheme of local govermment, the decision, of eourse, rested with the States, ear:h choosing for itself. Barch, without exception, chung to the Einglish heirlooms, attempting no imovation. Lonisianal, entering the Union at a later diay, preferred to retain the French organization to which she was ancustomerl but with the single exception of Lomisima, cerery one of the forty-four States now contained within the linited States, - the original Thirteen as whll as the balkotiss, Washington, Montania, Idlaho, and Wyoming, the communities athled but now, - are in their polities from top to bottom English, aneh inheriting

1 American Commonwealtla, 1, p. $4 \$ 0$. 
the priceless treasure of the English common law, each in all the details of administration inheriting English forms, traditions, and nomenclature.

As regards the Federal Constitution, the following of English precedents is just as apparent as in the case of the forms of local self-government. When the Federal Constitution was formulated and sent out to the States to be ratified, the exasperation against England was extreme, and the friends of the measure in recommending it were as reticent as possible as to their obligation to the mother-country. The papers of the "Federalist," for instance, are marked by this reticence. With only one or two exceptions, however, the features of the federal scheme The President are distinctly English. ${ }^{1}$ The resemblance The President
the English
Klng of the of the President to the British King of the eighteenth end of the eighteenth century is obvious. Each possesses the executive power, commands the army and navy, makes treaties, appoints ambassadors and judges, - all with the advice and consent of the Upper House of the legislature; each has a qualified veto on legislation, and the power of convening the legislature in extra session. It is probable that the constitution-makers constructed their chief magistrate simply by reviewing the powers of the King and modifying them where they appeared excessive or unsuitable. At an earlier and at a later time, the British Sovereign was something very different; but the only essential distinctions between the powers of the Presidency and of the Kingship, as it was under George III, are that the Presidency is not hereditary, and can be held

${ }^{1}$ Sir Henry Maine: Popular Gorernment, p. 211, etc. 
(without re-election) for only a short term. At present, the President has much more power than the English Sovereign; much more, too, than was possessed by the first Hanoverians; much less than was possessed by the Tudors; than was claimed, though unsuecessfully, by the Stuarts. As to the method of electing the President, we have the most important departure from English precedents which the Federal Constitution-makers allowed themselves. In the old day when Anglo-Saxon freedom remained unimpaired, the King was eleeted by the people in the great folk-moot, and in a later time by the witan, in the pres-

The Flectoral College bor. rowed from the IIoly Ro. man Emplre.

ence and with the eonsent of the people, whose acclamations, as we have seen, were craved at coronations, during many centuries, as an essential part of the ceremony: in America, however, a selected body was provided for, the Electoral College, which, though itself proceeding from the people, was to take the election out of the hands of the people, that the choice might be made hy a small eirele especially enlightencel. This feature of the Constitution was borrowed from the lloly Roman Empire, in which a small horly of Kurfïrsten met to determine upon the supreme magistrate. The Electoral College is the most conspicuous failure of the Constitution. The precedent upon which it wats hased was also a failure. Both in Germany and Amerian, the failure proceested from the same canse: the elertors fell, in Cicrmany, moter the control of the dominant fartions of the French or Austrian party, - als in Amerivil. they fall unker the control of the Republican or Demoeratic party. 
As to the legislature, the bi-cameral feature, the two Houses, bears the plain mark of a British The House of original. In old France, there were three

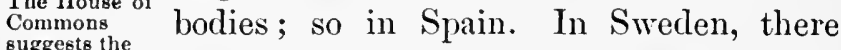
suggest the
House of lep- were four estates. The House of Repre-
resentatives. resentatives. sentatives is unquestionably a reproduction of the British House of Commons of one hundred years ago, though the two bodies exhibit at present in some points a wide divergence. Each is constituted of nembers elected by a popular franchise; each has the power of originating all money-bills; a century ago, the House of Commons, like the House of Representatives, was restricted to legislative functions, and had no voice in the appointment of the Cabinet. The present far-reaching and constant interference with the executive through the interrogation of ministers, is a recent acquisition of power; while the right of the Commons to designate Cabinet ministers, at present thoroughly established, was sucAnalogy be- cessfully disputed by George III. The tween llouse
of Lords and analogy between the Upper Houses of the Senate.

English and American Legislatures is much less marked than in the case of the Lower Houses. The complete absence in America of a class of nobles, compelled the Constitution-makers to look elsewhere for the means of forming an Upper Chamber. Following at last the suggestion of Connecticut, they hit upon the happy expedient of making the Upper House "reflect the original political equality of the several states." I Without regard to amount of territory, wealth, or population, it was ordained that each State should send two members to

1 Maine: Popular Government, p. 229. 
the Senate. The adoption of this provision in 1787, not only made possible the aceeptance of the Constitution, but has proved sinee one of the best strokes in the memorable work that was then done. While in a general way acting like the House of Lords, to restrain and supplement the work of the Lower House, the Senate has executive functions, also, whieh, as time has passed, have developed into greater importance. From the ontset it has possessed such a dignity of character, and its action lias been attended in every stage of our history with eonsequenees so salutary, that it must be regarded as one of the most fortunate creations of the Fathers.

The Supreme Court, finally, which in the Federal Constitution represents the judicial function, as the President represents the executive, and Congress the legislative, has been held by Preecents De Tocqueville and other writers to be preme court. a brilliant American invention. Sir Henry Maine regards it as something unique, ${ }^{1}$ but funds in its make-up and in its forms of procedure, marks of English originals. Bryce goes still farther, elaiming that it is throughout baser on English precerlents. The British julges, irremovable exeept by impeachment, are its model. It can act only indirectly, in special eases in which the United States, States, and individuals are parties; a declaration of unconstitutionality not provoked ly a definite dispute is unknown to the supreme Court. "Much that is really" English appears to De Toequeville to be Ameriain or democratic. The function of the judges. for instance, in expoumling the Constitution and dis-

1 Maine: Popular Goverument, p. 217, etc. 
regarding a statute which conflicts therewith, ... is a mere instance of a general doctrine of English law adapted to states partially subordinate to a federal government." 1 No authority weighed so much with the Constitution-makers of 1787 as Montesquieu, as appears from the frequency and the Infuence of reverence with which the "Esprit des "Eontesquieu's Lois" is cited in the "Federalist." Special Lois." weight is given to his assertion of the essential separation in a proper polity, of the legislative, judicial, and executive powers. The distinction has become now a commonplace of politics, but it was recognized only slowly. The different nature of the legislative and executive functions was not appreciated until the fourteenth century; and that the judicial stood apart from both was a discovery of the eighteenth. " There is no liberty," declared Montesquieu, " if the judicial power be not separated from the legislative and executive"; and in this declaration we find the source, no doubt, of the Federal judicature in the Federal Constitution.2 Neither the Supreme Court, nor in fact the Federal Constitution in general, would have been likely to come about had not the "Esprit des Lois" been written. But the great French thinker was led to his views while contrasting admiringly the institutions of England with those of lis native land ${ }^{3}$ and

1 Bryce: Johns Hopkins University Studies, 5th Series, IX, p. 26.

2 Maine: Popular Government, p. 220.

${ }^{3}$ In the English constitution, as now developed, the legislative, executive, and judicial functions are by no means separated as Montesquieu conceived they were in his day. "The efficient secret of the English constitution is the close union, the nearly complete fusion, of the executive and legislative powers. The connecting link is the Cabinet." -Bagehot: English Constitution, pp. 2 and 10. 
in adopting his thought, the founders of America had ready to their hands English constructions which needed only to be transferred.

The Constitution of the United States, then, is by no means a new political departure, but merely a modified rersion of what stood in England between 1760 and 1787. Cireumstances excluded an hereditary King and nobility. and the variations to be noted are chiefly due to this exclusion. As in the local govermment of town, parish, comnty, and State, almost no change is made, the citizen arlministering forms into which he was born and for the working of which he has an hereditary aptitude handed down through many centuries; so as regards the Federal instrument, nearly all is old. The stability of America is, no doubt, owing to the great portion of England which is thus cmbedded in it, though the sagacity must be admired with which the founders filled up the interstices left by the inapplicability of certain of the then existing English institutions, to the emaneipated colonies. ${ }^{1}$ What was excluded, in fact, was that in the English polity which mate agrainst the Anglo-saxon freedom, the alsolutism and privilege which had come to pass in later times becalso the powerful were detemined to eneroach, and the people were negligent in maintaining their birt hright. Whrn all was done, and the great growing nation had had time to aceommodate itself to its political garment. it was found that it was grovernment of. hy atul for the people which haul been provided for: Though notling important, either in State or Foderal Comstitution

1 Maine: Popular fovermment, p. $25 \%$. 
was new or un-English, something important had been sloughed off. Moreover, it is an innovation that there must be for State and for Union, the Constitution, the rigid, carefully formulated instrument by which legislature, executive, and judiciary are to be carefully bound; not to be amended but by a process of some difficulty, - in the case of the Federal instrument so difficult as to be seldom practicable. It has

Sir Henry

Maine's admi- "like the dikes and dams which strike the ration of the Federal Constitution. eye of the traveller along the Rhine, conacted for America, says Sir Henry Maine, trolling the course of a river which begins amid mountain torrents, turning it into one of the most equable waterways in the world." 1 It was this restored Anglo-Saxon freedom, so similar to that of the plains of the Weser and Elbe two thousand years ago, in all its main outlines, however its adaptation to a higher civilization and a vastly larger nation may have caused development, - sovereignty of the plain people, safeguarded and carefully ordered as long experience advised, - which one hundred years ago, April 30, 1789, Washington, as Chief Magistrate, made oath to administer.

1 Popular Goverument, p. 245. 


\section{CHAP'TER XVI.}

THE NEW COLONIAI EMIPIRE, AND TIIE REFORM BILL OF 1832 .

George IV, 1820. William IV, 1830. Victoria, 1837.

With the loss of the thirteen American colonies, the greatness of England seemed quite destroyed. Far-seeing statesmen of her rival, Frunce, French antici. had sought comfort at the time when Que- pation of Engbec fell before Wolfe, in the anticipation the close of that the colonies, freed now from fear of kevolution. a hostile power always ready to descend upon them from Canala, no longer needing protection, would soon throw off the dependence by which protection had been accompanied. The anticipation was well based: the spirit of independence at once appeared, as Choiseul, Argenson, Kalm, and other foreign observers harl believed it wonld. France fanned the discontent; when the disputants came to blows, she gladly lent Amerina money and men; when at Yorktown the British army surrendered and American independence beeane certain, France thought her revenge complete, and saw nothing in the futme but her own mulisputed supremary in the civilized world.

The ill-wishers of Eingland saw far, lut not far enongl. The independence of Ameriea crippled the island kingrom for in moment only: at the now they same time it established the suprematey in were fro 
the world of the English tongue, of English freedom, of English ideas in general, - a supremacy before which France was destined to sink irrecoverably. Since the establishment of the United States, the life of the English-speaking race has had two currents instead of one: the older has not lesscned, while the newer current has flowed with a force which has changed the face of the world. ${ }^{1}$ With the adoption of the Federal Constitution, America began her separate course. Within thirty years England had acquired a new colonial empire vaster even than the one she had possessed at first. Taught by experience, she has managed these newer dependencies with wisdom: the connection which the Thirteen Colonies rejected, the new empire has carefully and affectionately cherished.

Not all of America became independent with the United States. Canada, lately conquered, containing

Why Canada did not join the United

States. a population of sixty thousand French, remained to England. Between Canada and the Thirteen Colonies had existed a fierce hereditary feud. In religion, as Catholies and Protestants, they were utterly antagonistic; for a hundred and fifty years, since the occupation of America by French and English, in fact, the wars between them had been almost continuous. The Canadians might hate England, but they hated her late dependencies still more. During the war of the Revolution, American invasions of Canada met with no support from the habitans; and since the British fleet could easily pour troops into the country and command from the St. Lawrence all the most im-

1 J. R. Green : History of the English People, IV, p. 270. 
portant points, such invasions were easily frustrated. At once after the close of the war, we have seen a cause beeome operative which greatly increased Canadian dislike. The expatriated Tories, to the number of many thousands, sought homes in Canada. The ideas they rejected had triumphed; through wholesale confiscation they had been stripped of all they possessed; the spots they loved had been barred to them. Deep resentment on their part was inevitable, - resentment which their descendants have not ceased to feel down to the present hour.

At the very time when the over-severe grasp of the mother-country upon America was being beaten off, the greatest of English sailors was lifting voyages of the curtain in the South Pacific behind Captain Cook. which lay concealed an immense new world. James Cook, in the "Endeavour," and the "Resolution," entering seas which, indeed, had been penetrated before by Portuguese, Spanish, and Dutch, but of which almost nothing was known, brought to the attention of civilized men the existence of vast habitable lands. Ie mapped out acemately the two entiguous islands of Now /oulaud, nearly as lauge as Italy, possessed of a climate most farorable to Anglo-Saxon men, and of the richest natural resourees of every kind. Coasting at great peril throngh the intricate barrier-reefs, along the farextending shore, from Van I)imen's Land to the northern rape of what is now (Dneensland, lae traced the position and shape of a new eomtinent, a land of the finest promise. How memomalile the elange these regions ware to experience during the hundred years that followed! Sordecly was the work of Cook aceomplishent when the (ap)e of (roml 
Hope fell to England out of the weakening grasp of the Dutch. Her empire of India, which the French had disputed, was a matter of no doubt after the ruin of Dupleix. Rodney's defeat of De Grasse gave her at the same time the West Indies. Points of foothold in long series were made firm in the sea, Gibraltar, Malta, Aden, Singapore, Hong Kong, Vancouver, Bermuda, Ascension, the Falkland Isles, stepping-stones over which England might proceed with speed and unobstructed, to succor or comfort her vast outlying dominions. It was not until the loss of the Thirteen Colonies, which seemed at the time so immense, so decisive of her decline, that, in the period of Webster, she became "that power whose morning drum-beat, following the sun and keeping company with the hours, fills the whole earth with one continuous and unbroken strain of the martial airs of England."

Studying the extraordinary expansion of the influence of England with reference to the spread in the

Distinctions to be made among the present dependencies of England. The East and West Indies. world of Anglo-Saxon freedom, we must, it is plain, make a distinction among the territories which form her great outlying empire. In India, for instance, she appears simply as a ruler. Two hundred and fifty millions own her sway, which is exercised by only a few thousand Englishmen, the civil officials and the regiments which form the nucleus of the army. The vast mass of the population live on, little touched by the ideas of the masters, - preserving their own religious ideas for the most part, preserving the ancient structure of society based upon caste; preserving in the whole internal administration of affairs, the 
political forms to which they have been accustomed. However much European eivilization may have reached a few individuals among elasses fortunately placed, the multitude know it not; as to the foreign lordship, they are only aware that they can follow their ancient ways with a peace which was utterly strange to the land while under Asiatic rule. Again, as to the West Indies, the Anglo-Saxon population, never large, steadily diminishes; while a multitude of blacks, descendants of the slaves brought from Afriea, a race yielding only slowly, and under very farorable contlitions, to the higher social forms, spreads constantly wider, threatening the islands with a reign of barbarism.

In quite a different elass from the East and West Indies must be placed Canadil, South Africa, New Zealand, and Australia. Each of these names stancls for a group of great terri- Canada, South tories in all of which the native races are tralasia. disappearing more or less rapislly; in all of which a large Anglo-saxon population is firmly rooterl, with all the alpliames of the lighest Eumpean civilization; in none of which has there prevailed the curse of an importation of an ensiared barbaric race. To What an extent these new lancls lave arlopted AngloSixom freedom, and how vast their influence has been and is likely to be with reference to it, will be lest understoml if we look tirst at a closely related change in the motherland, - a change which followed and to a large extent depended nom the loss of the Thirteen colonies, - the enfranchisoment of the plain penple. namely: for this was the deep funclamental cause of benefits incalenlable. 
Even before the close of the American war, clear symptoms were not wanting of a great change in the Pitt's agita- condition of England. In 1782, Pitt moved tion of Parlia- in the House of Commons for an inquiry
mentary reform.

into parliamentary representation, looking toward a radical reform of its abuses; and in this he was supported by members of great eminence, by some, indeed, who usually stood in opposition to him, like Charles James Fox. Pitt's proposition came very near prevailing; a majority of only twenty rejected it. Pitt brought forward his scheme again in the following year, when its popularity seemed not diminished. While Parliament was on the point of taking a momentous step, the aroused nation, pressing vigorously for a more satisfactory representation, was in a ferment. Especially noticeable was the action The Friends of a great society, known as the Friends The Friends
of the Peo. ple.

of the Supporters of the Bill of Rights, which had become famous in the time of Wilkes. The Friends of the People stimulated in various ways the desire for a better political condition, working with especial effect by means of the distribution of facts and figures which gave startling illustration of existing abuses.

But while all signs promised an immediate reform, the attention of England was suddenly diverted elsewhere; the disposition to change underwent a sudden cooling; the transformation of England into a freer and better ordered state was postponed for an entire generation. What arrested the operation of causes that had shown such activity was the French Revolution. In its earlier stages, it had been by no 
means without sympathy in other lands than France; the leaven spread abroad by Rousseau and his followers had been working, indeed, throughout the eivilized world. Even General sym. pathy with the Russia had been touched by the influence, French Revowhere Catherine II meditated certain ameliorations of the condition of her subjects, to some extent in aceord with the humane striving of Joseph II in Germany, with that of Pombal in Portugal, even with the effort of the founders of America, who in a spirit not altogether democratic, it must be remembered, had laid the basis of a great state across the sea. England was by no means eold to the new ideas: her thinkers to some extent echoed them; her younger poets, Wordsworth, Southey, Coleridge, were ablaze with the generous fire; the people recognized in the upspringing freedom across the Channel something akin to what they desired; and the liberal leaders weleomed the spread of thoughts so likely to promote the generous measures they themselves lad at heart. All. however, was transitory. The morning that had dawned so fair speedily became over- keaction on cast : the excesses of the Reign of 'Terror account of the frightened into silence the roices that hat ror.

been advocating lilkerty. Prerogative, privilege, ahsolutism in the ruler's chair, the assumptions of a prefered elass, - in every lind in Europe the bols upon the world of these hoary aluses, which just before liat secmed to be so thoronghly shaken, beeame suddenly confirmed. The nations, lecome reationary, banded themselves against France, where liberty had lassed into license; and in the forefront of the Allies, with burke lannenting dongently the fall of 
the dynasty of Hugh Capet, and thundering fiercely against the democracy that had destroyed it, - with Pitt suppressing his popular sympathies, and rousing into life and ranging for battle all the ancient aristocratic forces, - appeared no other than England. For a time the voices that spoke for the rights of the people were quite silenced. Dukes and viscounts led armies and fleets ; Parliament, made up of a reinvigorated House of Lords, and of a House of Commons sent by rotten boroughs and by shires bought up by moneyed and titled magnates, sanctioned and supported. The mass of men meanwhile, reaping much gain from crops and manufactures because embargoes shut out foreign competition and the waste of warfare caused an unnatural demand, shuddered at what they heard of the work of the guillotine, paid their taxes, sent their sons into ranks and on to decks which the French cannon forever swept bare of men, and suffered their aspirations after a better order thoroughly to cool.

A change, however, came. Waterloo brought peace, and also a time of reckoning. The morbid Cessation of prosperity of the years of war was folCessation of
the reactiou at lowed by debt and deep distress. The
Waterloo Waterloo.

Holy Alliance proceeded to fix upon Europe a chain of tyranny quite intolerable. In the House of Commons of 1816 the very bottom of abuse was touched. Of the 658 members but 171 could by any stretch of construction be regarded as popular representatives; while the members who were nothing more than nominees of the government and of private patrons numbered 487 . The private patrons, again, counted but 267, of whom 144 were members 
of the House of Lords. ${ }^{1}$ It was the hour of special darkness just before day. The spirit of agitation for change was again in the air, becoming reform. more pervasive and imperative with each year that passed, mitil a temper prevailed which the forces of privilege eould no longer resist. In March of the year 1831 eame the memorable introduction by Lord John Russell of the first Reform Bill.2 Heals of petitions lay on the table, the venerable hall of St. Stephen's was erowded, dense masses of people stood outside waiting for the news, and beyond them were horsemen ready to carry the first information of the details of the bill to every part of England. The chief evils demanding remedy were: 1 . The existence of rotten horoughs, places with few electors, sometimes, indeed, with no inhabitants at all, which returned members to Parliament. 2. The fact that large towns, which harl grown into importance through commerce, were left without representation. 3. The unequal distribution of the framchise itself, so that only a small part of the population had the right of roting in elections. The bill proposed that sixty of the smaller boroughs should be disframehised altogether; that forty-seven shomld return only one member, instead of two; on the other hand, London was to receive eight additional representatives. and thirty-four seats were to lo distriluterl among a number of towns haretofore unrepresenterl. The Engrish comoties hanl alletten to them fifty-five new members: the seoteh. five: the Irish, three : the

Ilannis laylor: Origin and (irowth of the English constitution, I. p. 1i13.

"Oscar Browning: Modern England, in Equchs of History Series, p. 14, 1!. 
Welsh, one. These changes would reduce the House of Commons from 658 to 596 . Corporations in boroughs lost the exclusive right of election, which was uniformly extended to all householders who paid $£ 10$ a year rent. These changes gave votes to half a million citizens who were before without them. The body of the people supported the bill, while the court, the Church, the army and navy, the lawyers, the universities, the nobility and gentry, were generally against it. The Tories said its passage would be a revolution; the Radicals would have preferred something nearer universal suffrage. The bill was lost, and Parliament was dissolved in April.

In a few weeks a new Parliament was elected. In the elections, in the midst of great excitement, reformers were chosen generally throughout the country. The second Reform Bill, introduced by Lord John Russell in July, was different in no important point from the first; it passed the House of Commons in September, by a majority of 106 . Earl Grey, the head of the ministry, whose name is most honorably identified with the cause of reform, introduced it in the House of Lords, but it was rejected by a majority of forty-one. A revolution seemed imminent. A cry was raised for the abolition of the House of Lords. Peers were attacked in the streets; sixty thousand men in procession presented a petition to the King. Riots prevailed. The Church shared with the aristocracy the hatred of the people. Parliament,

Passage of the Reform Bill of 1832 . after prorogation, met again in December, and the third Reform Bill was introduced, little changed from its predecessors. It passed the Commons, March, 1832. The Lords, as 
before, blocked the path, bringing upon their heads a fierce storm of popular disapproval, in the midst of which permission was given by the King to Earl Grey and Lord Brougham, the heads of the ministry, to create such a number of Peers out of men friendly to the measure, as would be necessary to pass the bill. Before such danger the Lords recoiled. The bill passed in June, only twenty-two Lords opposing; William IV refused to sign in person, and a commission was appointed for the purpose. The momentous struggle was over; it was apparent that there was no power in the State which could resist the House of Commons when it had become onee fixed upon its course.

The reform, so great that it ought rather to be called a revolution, at onee justified itself. A spirit of moderation was shown in the elections. The new Parliament, really representative of the parsage for the first time since Cromwell, was guilty of no follies, but forthwith remedied evils of whose abatement there had been muler the old order no hope. In England and Ireland the pressure exereiser by the established (hureh was greatly lightened, slavery was presently alolished in the dependeneies, cheap) postatge was intmolnced, a begrinning male in alleviating the hardships of factory life. and a crant allowed for exhuration. It soon beeame applatent that a deep-seated brutality, which long had marked the mass of the perple, was latrerly due tir the denial from which they had suffered, of pelitical rights. The exerrise of the new privilegras harl a most wholesome effect in edureating those who now

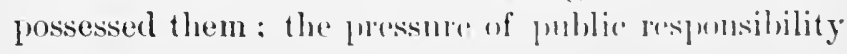


evoked manhood in those who were subjected to it. These results, which no reasonable observer could fail to remark, prepared the way for still another instalment of popular liberty. The reform of 1832 had been only partial. In thirty years the demand became strong for something more; as before, years of agitation, less violent, however, than at first, preceded action. In 1867 , the franchise was put into the hands of new millions; and in 1884, by the admission of the agricultural laborers, it was still further extended. Scotland and Ireland were placed upon the same footing; a re-arrangement and equalization of the constituencies took place upon the most equitable principles ; and it became possible to describe England as transformed England prac. into "a republic, in which, under the England prac- ancient and still useful forms of the
ticallya re-
public. public. throne and the regalia, the People is King "; ${ }^{1}$ a state which has far more in common with the ancient time, when Anglo-Saxon freedom was fully alive, than with the intervening ages when Anglo-Saxon freedom was suppressed. ${ }^{2}$

At the present hour no power in England can stand against the House of Commons, which has power of the become as thoroughly representative of Cabinet. the people as was ever the folk-moot of the tribes in clistant antiquity. Montesquieu praised the separation of the legislative, the executive, and the judicial power, which he thought he could see in

1 H. Taylor: Origin and Growth of the English Constitution, I, p. 166. "The appendages of a monarchy have been converted into the essence of a republic.... It is only a disguised republic which is suited to such a being as the Englishman, in such a century as the nineteenth." Bagehot: English Constitution, pp. 285-291.

2 Freeman: Growth of English Constitution, p. 158. 
the English polity of his time; and the makers of the American Federal Constitution felt that such a separation was essential to a well-ordered free state. However this may be, the distinetion has disappeared in England, where the executive has a ruling voice in legislation, and where the legislature interferes constantly and profoundly with the functions of the executive. To understand this, the immensely important functions of a group of officials must be understood of whom the ancient constitution knew nothing; whose character and duties, it is said, indeed, have never been formally laid down. This group is known as the Cabinet, a name applied at first by way of reproaeh. We have seen it appear in the reign of William and Mary, at which time, to remedy great embarrassments, the experlient was hit upon of having the King select his ministers from the majority in P'arliament, that they might be always in aceord with themselves, and have behind them a power able to arry through whatever schemes they might have in view. In the "responsible government" which has come to pass out of this provision by a process of evolution comprising many stages, the sovereign retains scarcely a shatow of real might. The learler of the parliamentary majority for the time being beeomes heal of the ministry; the other prominent men of his party beeome his colleagues, and to them solely is committed the execution of the majority's will. In legislation. it is left to them to take the initiative; while in cxeroting measures that have been resolverl upon. the ministers, sitting in their seats, are subjowted to constant questioning and criticism, - a process which the 
minority, the Opposition, always take care shall be sharp and searching to the last degree. Whenever a measure of the ministry fails of support from a majority in Parliament, the ministry falls, the leaders of the new majority at once stepping into their places. If the discomfited ministry choose, an appeal can be made to the country; Parliament is dissolved, and elections are ordered for a new Parliament. In the elections, the sovereign people express their will: the ministry may be sustained when the new body assembles, or it may fail of support. If it has not the majority on its side, it must cease to exist.

Such in its broad outlines is the shape into which the polity of England has at last grown. In electing Present state the House of Commons but few Englishof the English men are now shut out. The Sovereign has
polity. become powerless; gaining, however, immensely in the love of the people since it has become clear that she is their servant and not their mistress. The House of Lords has no power; though nominally possessed of the right to revise and co-operate in the work of government, its stubborn opposition at any time could at once be frustrated by the creation, on the part of the ministry, of new peers in sufficient numbers to overcome the resistance. As at the time of the Reform Bill of 1832, such treatment was threatened, and the Lords at once succumbed, so it must always be. The Cabinet guides legislation, and under constant fire from the Opposition pursues whatever policy it thinks fit. The Cabinet reflects the majority of Parliament, just as Parliament itself reflects the nation. A healthful air of publicity blows through all proceedings. Each syllable uttered 
in the national council, caught by eager reporters, is spread broadeast next day by means of thousands of newspapers. Comment of every kind, applause and fauit-finding, are as outspoken in every constituency as within the Palace of Westminster itself. Government of the people, by the people, and for the people, can proceed but little farther.

Are there grounds for fearing that the people of England are inadequate to such responsibilities? Says Lord Farnborough (Sir 'T. E. May): "That Englishmen have been qualified for the sdequacy of enjoyment of political freedom is mainly the people to due to those ancient local institutions by sibilities. which they have been trained to self-government. The affairs of the people have been administered not in Parliament only, but in the vestry, the town-comcil, the board-meeting, and the Court of Quarter Sessions. England alone among the nations of the earth has maintained for centuries a constitutional polity; and her liberties may be ascribed above all things to her free local institutions." What misfortunes the shire-mont and the tun-moot have undergone in their transmission through the ages we hate had occasion to notice as om survey has proceeded. 'That they have been to a large extent overlaid las been male plain; and it is certain that in proportion as they have been thrust back, a baleful torpor and clegralation have fallen upon the people. But though overlaid, the old local self-govermment has never been oblitrated. "Since the days of their Saxon ancestors," contimes May, "England's sons have learned at their own gates the duties and responsibilities of ritizens. Associating for the common gool, they have become 
exercised in public affairs. Thousands of small communities have become separately trained to self-government, taxing themselves through their representatives for local objects, meeting for discussion and business, and animated by local rivalries and ambitions." 1

The testimony of the great constitutional historian is amply borne out by other authorities, among whom J. Toulmin Smith may be eited. "This system of local self-government, by which there were fixed, frequent, and accessible meetings together of the folk or people, for discussing and determining upon all matters of common interest (that local self-government that affords the most valuable education both as to thought and action, the best school for the faculties of man), is a system the skeleton of which still exists, though it has been much overlaid. The fact is clear and unmistakable that such a system of local self-government, minutely ramified and wisely devised, has never been quite superseded." 2

In the better England of to-day the signs are hopeful for a vigorous revival of what has so long been The County atrophied. By a sweeping measure of the councils. year 1888, Parliament, brushing aside a mass of cumbrous and hurtful mediæval lumber, gave the government of the shires once more into the hands of the people after the old fashion. In the new County Councils, freely elected representatives once more care for the business of the shires, as did long ago the Reeves and four men sent by the townships to the central moot, to speak the will of the

1 Constitutional History, II, p. 460.

2 Local Self-Government and Centralization, p. 29, etc. 
ceorls. As far back as the year 1848 the illustrious Cobden anticipated what has now come to pass in the shires, and expressed the belief that the head of each shire might be an official somewhat analogous to a State governor in the United States. He felt that a radical transformation of the House of Lords was impending, and had an idea of an Upper House resembling that of America, in which each county should he represented by two senators. ${ }^{1}$

An American naturally feels that such a change would be salutary: it is at any rate quite in the spirit of the ancient Anglo-Saxon freedom. In municipalities, too, an administrative system far nearer that of the old borough-moot, so distinctly marked in the time when the cities were rising, than the oligarchic abuses that displaced it for so long, has come to prevail. The plain people, while pusling themselves to the front, have certainly not been neglectful of the means by which they may best fit themselves for the responsibilities which they hre assmed.

In the transformation of England, so marked since 1832 , and by no means ats yet at an end, the voices of the timid are constantly heard depreeating innovations; and as constantly the voices of scholans and thinkers declaring that the so-called innovations are lut a reverting to ancient precedents. In the momentous debate and strife the incidents are sometimes startling. It has been felt often that no other so audacious hand has in our generation been nenry laid upon the very foundations of society and property as that of Henry Feorce; reform.

1 Ietter to George Combe, A ugust 2x, 144. Morley: Life of Cobden, p. 327. 
but to make real Henry George's theory of land-holding, it is now claimed, it would only be necessary to revive that primitive system of tenure, in use through all the early centuries, and never down to the present moment entirely discontinued, by which the land was owned by the community, no individual being in such a sense a proprietor that he could call even his homestead his very own. ${ }^{1}$

In the circumstances, it is only natural for patriotic Englishmen to wish there was something to balance Flexible and and serve as a brake to the car of the rigid consti-
tutions. State, as it sways and plunges forward along

these lines of change. Even though progress be but a return to the old, is the return wise always? and if wise, would it not be expedient to return at a far slower rate, with more respectful treatment of mediæval traditions, - unwisely adopted perhaps in their day, yet still revered for centuries, and not to be left behind without much risk to the social and political framework? At present, the House of Commons is omnipotent in the State. As Christian, the commentator upon Blackstone, expresses it, if the House of Commons should see fit, like Herod, to pass a law to kill all children below a certain age, there is no authority to restrain it. ${ }^{2}$ Of Britons of conservative temper, no spokesman more entitled to respect has been heard of late years than Sir Henry Maine, ${ }^{3}$ who looks across the Atlantic with admiring eyes at America, deeming her most happy in the possession

1 The Land and the Community, Rev. S. W. Thackeray, 1889. See also Progress and Poverty, Book VII, Chap. IV.

2 Blackstone's Commentaries, I, p. 91.

s "Popular Government," by Sir Henry Maine. 
of her Supreme Court, her powerful Senate, her rigid, authoritative instrument behind the legislature, checks most effectual when popular whim is disposed to go too fast and too far, checks which England is utterly without. To reverence the Constitution is, of course, a sentiment which every American drinks in with his mother's milk; and all who wish well to the mother-land will desire for her that as she takes on new things, some such powerful guarantees of order and stability may eome. Possibly it has been, and is still, a fortunate circumstance that in this time of reconstruction the British constitution has been, in Bryee's phrase, "flexille." When, however, the effete feudalism is thoroughly sloughed off, one feels that the constitution must be "rigiel," - that there must be some wisely framed instrument to stand as law over even the law-givers.

England is not only herself at the present hour practically a demoeratic republie, but is the parent of vast republies in the quarters of the earth most distant from her. ${ }^{2}$ In America, Australia, and Afriea, eighty per cent of the territories lesst adlapted by rlimate and soil to the habitation of Europeans are in her possession, and have beeme the seats of vigrorous and growing $A$ nglo-sixon preples. The extent to which these have leerome endowed with the ancient frectom so thoroughly reevered hy the mother-land, can be made plain in a few words. The old colonial empire, the 'Thirteen Colonies, which, after revolting,

I See vlew of Ilon. Seth low, in Bryce: American Commonweallh, I, p. 6833.

2Sir T. Erskine May: Constitutional History, II, p. 5.37. 
became the United States, had been ruled after the precedents of Spain. The dependencies were regarded as a source from which the mother-land might be enriched, and their interests were neglected and sacrificed in the pursuit by the nother-land of this selfish end. "Till alienated by the behavior of England, the colonists had far more kindly feelings toward her than she had toward them. To them she was the old home; to her they were simply customers." 1 Exasperation in the Colonies was the inevitable fruit of so base a policy, and in the end England, like Spain, lost the new lands whose rights she had abused. The bitter experience, as we have seen, perhaps saved her own freedom; she derived from it also the wisdom which enabled her, when presently the vast new colonial empire fell within her grasp, so to proceed that the dependencies, instead of chafing under their bond, cherish it with warm affection, looking upon independence as a calamity rather than a blessing.

The independence of America had been not long secured, when the foremost men of England began Pitt's Colonial Bill of to utter the wiser doctrines as to colonial 1791 . rule, which were to prevail in the future. In 1791, Pitt introduced a bill for the government of Canada, "remarkable as recognizing for the first time the wise and generous principle of independent colonial institutions, which since then has been fully developed in every dependency of the British Crown capable of local self-government." 2 At the same time, Fox, though in opposition to Pitt, exclaimed that "the only method of retaining distant

1 Bryce: American Commonwealth, 1, p. 416, note.

2 Massey : History of Fingland from the Accession of George III. 
colonies with advantage is to enable them to govern themselves." Both Whigs and Tories share the credit of this model for all subsequent colonial constitutions. ${ }^{1}$

But though the proper plan was recognized, it was not at once put in practice. England, absorbed in the struggle of the French revolutionary and $\mathrm{Na}$ poleonie period, though she snatched from her enemies rast foreign possessions, had little leisure to organize and administer with care. Canada was neglected until she rose at last in rebellion; while the only use found for Australia was as a prison, fenced off from England by many thousand miles of sea, to which criminals could be transported. By such transportation much had been done at an earlier time to blast the prospects of portions of America. The evil policy was pursued in the South Sea for many years with so much energy that only ruin seemed possible for the country which nature had made so inviting. The day of better things eame with the year 1832, and the admission in England of a vast lorly of the plain people to a share in the govermment. Parliament herame at onee in every way more lummane and wise; and not the least of the improsenents which it introdnced into the arlministration of the empire, was the freedom from home interference which it very soon bestowed upon the colonies. They raprilly increased until at the present moment the population of canatal, gatthered into the great provineses. conferleraterl, after the eximple of the C'nited states. into the Dominion, numbers five million:

Frrestom of lirester $13 r$. tain.

\section{Yonge: Constitutional History, p. 128.}


the seven great lands that make up Australasia (New South Wales, Victoria, South Australia, Western Australia, Queensland, Tasmania, and New Zealand), together with South Africa, contain as many more; and all possess, or are likely very soon to possess, the same "responsible government" which puts the mother-country so thoroughly into the hands of its citizens. A Crown-appointed governor in each colony represents the Sovereign, and like the Sovereign, though possessed of dignity and irremovable by the people, is quite without real power. A legislative council composed of members, sometimes elected, sometimes appointed by the governor, forms an Upper House, no more potent than the House of Lords. The real power rests with the representatives who sit in the Lower House. As in England, the leaders of the party in the majority form of necessity the ministry. If they lose the support of the majority, at once they fall. An appeal may be made to the country, indeed; but if the country, in the elections which then take place, fails to sustain them by a majority, place must be given to ministers who stand for what the body of the people demand. In Canada alone, as yet, a confederation has come about of the provinees lying from east to west. ${ }^{1}$ Here each province has its legislature, in all main features like the federal legislature, which convenes at Ottawa. The example of the United States near at

1 For the constitution of Canada, see Appendix E. Sir H. Parkes, premier of New South Wales, says that Canada is to be the model for Australian federation. In the near futnre three English-speaking federations - the United States, Canada, and Australia - are to dominate the Pacific. - Sir Charles Dilke: Problems of Greater Britain, pp. $58,59(1890)$. 
hand (whose precedents, however, are always critically scanned) has brought this about. ${ }^{1}$

In Australia, there has been as yet no effective federation of eontiguous colonies, though propinquity, and interests to a large extent common, are making it imperative. Whether federal or otherwise, the self-government in each great dependeney is eomplete. Any power of veto which may in a strict construction of the eonstitution belong to the governor is never exercised, and has as completely fallen out of use as the veto power of the Sovereign of England. Though some eonstitutional writers still claim that Parliament is supreme over the colonies, and can annul, if it should ehoose, any action of a colonial legislature, ${ }^{2}$ no assertion of that supremacy has been made in any conspicuous manner sinee the unfortunate effort in the reign of George III; and if made, would exeite indignation unbounded. ${ }^{3}$ As the Crown has gained in ease and popularity what it has lost in power, so the mothercountry, allowing to the full the prineiples of local self-government, has won her dependencies to her-

'As to local self-government, Sir Charles bilke speaks with enthusiasm of that of Canada in geueral, and cills that of the province of Ontario "the best in the whole worll." Here, olected in each village and township, appear a "Reeve aml four comeillors," - a complete revival of the ancient name and usage; for the fireves, each with lis four, make up the rouncil of the slipe. In Queinec, tom, the mayors of the munieipalities make up th" ionuty comucils, thomeh the name "livere" does not appear.-. "Problems of (ireater britain," pr.tit.

2 J. 211 .

s"Only when the obligations of the empire to a foreinn power are affectorl, or an imperial statute is infringerl, in matters on which the Canalian larliameut bas not full juriselietion, is the supreme anthority

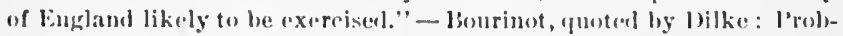
lems of (ireater liritain, J. 5l8. 
self. As Sir 'T. E. May remarks : " "No liberty or franchise prized by Englishmen at home has been withheld from their fellow-countrymen in distant lands. Thus the most considerable dependencies of the British Crown have advanced until an ancient monarchy has become the parent of democratic republics in all parts of the globe. The Constitution of the United States is scarcely so democratic as that of Canada or Australia. 'The President's fixed tenure of office and large executive powers, the independent position and authority of the Senate, and the control of the Supreme Court are checks upon the democracy of Congress. In these colonies, the nominees of a majority of the democratic assembly, for the time being, are absolute masters of the colonial government. England ventured to tax her colonies and lost them. At last she gave freedom and found national sympathy and contentment. But in the meantime her colonial dependencies have grown into affiliated States. Instead of taxing her colonies, England now has taxed herself heavily for them. She may well be prouder of the vigorous freedom of her prosperous sons than of a hundred provinces subject to the iron rule of British proconsuls. And should the sole remaining ties of kindred, affection, and honor be severed, she will reflect with just exultation, that her dominion ceased, not in oppression and bloodshed, but in the expansive energies of freedom, and the hereditary capacity of her manly offspring for the privileges of self-government."

1 Constitutional History, II, p. 538, etc. (summarized). 
In 1886 occurred in London a memorable scene, which a newspaper of the day thus describes:-

"The Queen formally opened the Colonial Exhibition to-day. The weather was beautiful, with brilliant sunshine. Crowds gathered along colonial Exhi. the route taken by her Majesty from bition of 1886 . Buckingham Palace and greeted her with enthusiasm. The main hall, in which the opening ceremonies were conducted, was crowded with the élite of London. The large number of foreign princes and diplomats, who attended in court dress, blended with the scores of British officers present in full glittering uniforms, made a magnificent speetacle. The Prince of Wales, the Duke of Edinburgh, Prince IIenry of Battenberg and his wife, Princess Beatrice, and Crown Princess Victoria of Germany led the royal procession throughout the building, and were followed by Lord IIartington, the Marquis of Salisbury, the Earl of Derby, and scores of other noble and distinguished persons.

"A prominent feature of the opening eeremonies was the ode composed for the ocasion by Tennyson. This was magnificently rendered by a vast ehoir of earefully selected voices. The ode was sung just previous to the Queen's formal declaration that the exhibition was open. The third portion of the orle was evidently composed with a view of stimulating intermational fraternity between the two great Engrlish-speaking nations, and is in the following words:-

\footnotetext{
"Britain fought her sons of yore;

Britain failed, and nerer more,

Carreless of our growillg kin,

Shall we sin urr fathers' sin. -

Men that in a narrower day
} 
(Unprophetic rulers they)

Drove from out the mother's nest

That young eagle of the West,

To forage for herself alone.

Britons, hold your own!

Shall we not, through good and ill,

Cleave to one another still?

Britain's myriad voices call :

'Sons, be welded, each and all,

Into one imperial whole ;

One with Britain, heart and soul,

One life, one flag, one fleet, one throne.

Britons, hold your own,

And God guard all!""

"The Queen was profoundly pleased with the ode and with the manner in which it was rendered by the choir. She nodded and smiled with pleasure, approved of each sentiment as it was brought out, and seemed exceedingly to enjoy the enthusiasm which the poem and music provoked in the vast concourse, whose applause was hearty, enthusiastic, and long continued."

Here, then, in America and the British Empire, we find in the world at present fully one hundred and ten millions of English-speaking men, all of whom are living under a popular freedom as complete as has ever been possessed by human beings, gathered in

Extension of Anglo-Saxon freedom to other countries. states, since the founclation of the world. Nor is Anglo-Saxon freedom confined to English-speaking races alone. Europe, in general, has passed through a century of revolution. Old institutions have been thrown off, and there has been in all civilized countries but 
Russia an adoption of the Anglo-Saxon polity, more or less modified. Such has been the ease with Franee, Belgium, Holland, Italy, Germany, Hungary, Sweden, Norway, Denmark, Spain, and Portugal. In all these lands, exeept Franee, which has a President, a Sovereign stands at the head of the state, in whose name executive acts are done, who is irresponsible and irremovable. The power lies with the ministers of the Sovereign, nominally appointed by him, but really owing their positions in a greater or less degree to the voiee of the majority of the representatives of the people. The representatives, therefore, through these, their agents, possess exeeutive as well as legislative power. This is the general seheme, the details of which vary widely. The supremacy of the legislature is most eomplete in France; least so in the German Empire, and in Prussia, where the power of the Emperor and King is great and not declining. ${ }^{1}$

$\Lambda$ still farther extension of Anglo-Saxon freedom is perhaps possible. The two limolred and fifty millions of India, it is believed, have a eapalcity for self-government. Every village has its headman and a ruling committee. Sir Itemry Maine, in his study of the village communities of India, presents interesting points of correspondence letween them and those of other Aryan peoples. In them exists a germ of local selfgovermment, if not of representative institutions, which might he devoloperl farr. East Indlians often possess high administrative talent. Mysore and Batroda, two of the largest provinces, within at few years have been given over to native rule. So it migrlat $b_{x}$ in

1 Bryce: American Commonwealth, I, 1. 271, etc. 
twenty different states. Why not a gradual substitution of native for English officers everywhere? it is asked. "A native administration, stimulated by English example, and still supervised by Englishmen, is not an unworthy idea. . . . A confederacy of many states and provinces, each developing peacefully after its own fashion, and united by a common bond to the English name, is our dream for the twentieth century." 1 The humane wish is entertained that Englishmen, while protecting and guiding, may yet for the most part surrender the natives of India to themselves, in the hope that, building upon the local self-government which has never become extinct, a government of the people may some day come out not remotely resembling that of their masters. ${ }^{2}$

Anglo-Saxon freedom, however, can only be ordered and administered with thorough success by AngloSaxon men. For these the impulse has It can be ad-
ministered come down in the blood, to struggle for it, only by
anglo-Saxon to cherish it, to live under it. 'To other men.

races it is something foreign; and as a strange tongue rarely becomes so free and flowing upon our lips as the mother-speech, so as regards this ancient freedom, there is rarely a thorough and easy adaptation of it to races that have worn chains. It is destined for the dominion of the world; and this supremacy it is to gain, not as adopted by peoples to

1 Cotton and Payne: English Colonization and Dependenee, English Citizen Series, p. 87. See, also, the "Westminster Review," January, 1889, artiele, "Federation vs. War," for a hopeful view of India.

2 See, upon this point, Dilke: Problems of Greater Britain, pp. 415, $425,433,437$. 
whom it is something alien, but as upheld by the English-speaking race, so many million strong, its separate nationalities planted at so many points of vantage the world over, no more one in speech than one in blood and institutions. 


\section{CHAPTER XVII.}

PRESENT CONDITION OF THE AMERICAN POLITY.

1789-1890.

While in the empire of England, Anglo-Saxon freedom has thus been adapting itself in throes almost revolutionary to the conditions of the nineteenth century, how has it fared in America? The thirteen States of 1789 have become in one hundred years forty-four; in population, area, resources of every kind, the Union has multiplied to a wonderful degree. As to constitutional changes, what have we to note?

The great federal instrument stands substantially unchanged. The few amendments, famous though some of them are, wrought out at such Permanence Permanence
of the Federal cost of blood and treasure, call for no Constitution. notice in the present discussion. The clauses of the Constitution have been regarded with a veneration ever deepening, until it has become almost superstitious; to think of meddling with its provisions is, in the general view, almost an impiety.

As regards the separate commonwealths, while each one of the forty-four has its peculiarities, ${ }^{1}$ the Distrust of general resemblance is close. A tendency legislatures. to greater elaborateness in the written con-

1 See Henry Hitchcock: American State Constitutions, Putnams, 1887. 
stitutions is to be noted, as new States have been added one by one, proceeding so far that in the more recent instruments a provision for minute details exists in strong contrast with the older documents. This circumstance is due to a growing distrust, in the States, of the legislatures; delegates in so many cases prove inefficient, corrupt, or in some way false to their trust, that the people think fit more and more to tie their hands. Undoubtedly this deepening dissatisfaction with legislatures. Congress itself as well as those of lower rank, is a eircumstanee full of ill omen. If the representative body is a failure, then is Anglo-Saxon freedom a failure, and the sooner we recur to the system of Strafford or Richard II, the better. The ideas of those historic figures are by no means yet obsolete among English-speaking men. ${ }^{1}$ Is Anglo-Saxon freedom no longer well adapted to English-speaking men? What can be said about the condition of the primordial cell of our body-politic?

In our human bodies, if the cellular tissue is healthy, the physician is sure all will ultimately go well. Bones may be broken, sinews Condition of sprained, a blast of malaria may have the primordial caused an ague, or improper food drspep- Anglowaxon sia. Various kinds of deep-seated trouble popularmoot. may exist, acute and even chronic; but if the primordial cell everywhere is sound, the patient will survive. The proper primordial cell of an AngloSaxon body-politic is lonal self-govermment by a consensus of individual fremen: in other words, the

'Ste Traill: Life of Strafford, Iss!, p. 224, ete., and notice of the same in Inndon "Saturday Review," November ! 1Ks!!. 
popular moot, the thing back of the representative body, the primary democracy where the individual rules, no man's voice weighing more than another's except in so far as ability and character give him weight. ${ }^{1}$ This primordial cell, so fundamental and needful, - is it in the Union in such condition that Americans can confidently thrust the shoulder under the responsibilities which the future has in store?

A broad division of the population of the United States may be made into those who live in cities and those who live in the country, - a division Examination of rural America.

quite necessary in the present discussion;

for local self-government is a far more complicated and embarrassing matter for cities than for rural populations. In 1790 , one thirtieth of the population of the United States lived in cities of eight thousand inhabitants or over. The ratio in our time of the urban to the rural population is very different, the proportion of the urban population having risen to one quarter of the total, and showing a constant increase. ${ }^{2}$

Looking first at the condition of the rural population, we shall find in the various States of the Union communities to be classed as follows: those in which prevails, first, the Town system; second, the County system; third, the Township-County or Compromise system. ${ }^{3}$ In the Town system, confined pretty much to New England, the population occupying a comparatively small area assemble regularly, and themselves

1 H. B. Adams: Germanic Origin of New England Towns, Johns Hopkins University Studies, 1st Series, No. II, p. 5.

2 Census Reports.

${ }^{3}$ S. A. Galpin : Walker's Statistical Atlas of United States, II, p. 10. 
diseuss and decide upon public matters, electing representatives to stand in their place in the legislatures of State and Union, but retaining in their own hands local government. In the County system, that of the South, the population elect officers upon whom they throw the burden of local government; there are no regular popular moots for the diseussion of public affairs, citizens contenting themselves with the mere election of the county officials: the latter, if unsatisfactory, are not subject to eheek or guidance from any formally constituted body, but are simply dropped at the next election. In the Township-County or Compromise system, the two other systems are variously blended: this may be seen in the States of the Middle and the West.

Beginning our discussion with the Town system, let us inquire whether New Englanders have preserved it in its integrity. In the immense dilu- Local self. tion which the old stock of New England government has undergone through the foreign human land. floods which have been poured upon it, its influence has of necessity been often greatly weakened and the charater of town govermment has been infuences modified, seldom advantageously. While which impalr multitules of the ancient strain have for- meeting. saken the granite hills, their places have been supplied by a Celtic race, energetic and prolific, whose tecming families throng eity and village, threatening to outnumber the Yankee element, depleted as it has been by the emigration of so many of its most vigorous children. To these new-comers must he adled now the French Canatians, who, following the track of their warlike ancestors down the river-valleys, 
have come by thousands into the manufacturing towns and into the woods, an industrions but unprogressive race, good haeds in the mills and marvellously dexterous at wielding the axe. Whatever may be said of the virtues of these new-comers, - and, of course, a long list could be made out for them, - they have not been trained to Anglo-Saxon self-government. We have seen the origin of the folk-moot far back in Teutonic antiquity. As established in New England, it is a revival of a most ancient thing. The institution is uncongenial to any but Teutonic men; the Irishman and Frenchman are not at home in it, and cannot accustom themselves to it, until, as the new generations come forward, they take on the characteristics of the people among whom they have come to cast their lot. At present, in most old New England towns, we find an element of the population numbering hundreds, often thousands, who are sometimes quite inert, allowing others to decide all things for them; sometimes voting in droves in an unintelligent way as some whipper-in may direct; sometimes in unreasoning partisanship, following through thick and thin a cunning demagogue, quite careless how the public welfare may suffer by his coming to the front. ${ }^{1}$ "Though the town-meeting of the New England of to-day rarely presents all the features of the town-

Picture of it thirty years meeting of the Revolution, yet wherever the population has remained tolerably pure from foreign admixture, and wherever the

1 I have embodied here some material from previous works, Johns Hopkins University Studies, 2d Series, IV, p. 16, etc., and also the Life of Samuel Adams, Chap. XXIII. See the latter work for a detailed sketch of the town of Boston, - the most interesting of New England towns in its most interesting period. 
numbers at the same time have not become so large as to embarrass, the institution retains much of its old vigor. The writer reealls the life, as it was twenty-five years ago, of a most venerable and uncontaminated old town, whose origin dates back more than two hundred years. ${ }^{1}$ At first it realized almost perfectly the idea of the 'Teutonic 'tun.' For long it was the frontier settlement, with nothing to the west but woods until the fieree Mohawks were reached, and nothing but woods to the north until one came to the hostile French of Canada. About the houses, therefore, was drawn the protection of a palisarle to enclose them (tynan) against attack. Though not without some foreign intermixture, the old stock was, thirty years ago, so far unchanged that in the various 'deestricks' the dialect was often ummistakably nasal; the very bobolinks in the meadowgrass, and the bumble-bees in the hollyhocks, might have been imagined to chitter and hum with a Yankee twang; and 'Zekle' squired 'Huldy' as of yore, to singing-sehool or apple-paring, to quilting or sugaringoff, as each season brought its appropriate festival. The sume names stood for the most part on tax, voting, and parish lists that stood there in the time of Philips war, when for a space the people were driven out by the Indian pressure; and the Fithers hat handed down to the molern day, with their names and blood, the venemable methods by which they regulated their lives. On the northern botundary a fatery village had sprung up ahout a water-power: at the south, too, five miles off, there was some rattle of mills and sound of hammers. For the most part,

1 Deerfield, Franklin Co, Massachusetts. 
however, the people were farmers, like their ancestors, reaping great hay-crops in June with which to fatten in the stall long rows of sleek cattle for market in December; or by farmer's alchemy, transmuting the clover of the rocky hills into golden butter.

"From far and near, on the first March-Monday, the men gathered to the central village, whose people made great preparations for the entertainment of the people of the outskirts. What old Yankee, wherever he may have strayed, will not remember the 'townmeeting gingerbread,' and the great roasts that smoked hospitably for all comers! The sheds of the meeting-house close by were crowded with horses and sleighs; for, in the intermediate slush, between ice and the spring mud, the runner was likely to be better than the wheel. The floor of the town-hall grew wet and heavy in the trampling: not in England alone is the land represented; a full representation of the soil comes to a New England town-meeting, - on the boots of the freemen. On a platform at the end of the plain room sat the five selectmen in a row, - at their left the venerable town-clerk, ${ }^{1}$ with the ample volume of records before him. His memory went back to the men who were old in Washington's administration, who in their turn remembered men in whose childhood the French and Indians burned the infant settlement. Three lives, the town-clerk's the third, spanned the whole history of the town. He was full of traditions, precedents, minutia of town history, an authority in all disputed points of procedure from whom there was no appeal. In front of

\footnotetext{
${ }^{1}$ Charles Williams, Esq., known and beloved far and near as "Dr. Charles."
} 
the row of selectmen, with their brown, solid farmer faces, stood the Moderator, a vigorous man in the forties, six straight feet in height, colonel of the county regiment of militia, of a term's experienee in the General Court, thus eonversant with parliamentary law, a quick and energetic presiding offieer. ${ }^{1}$

"It was indeed an arena. The south village was growing faster than the 'Street,' and there were rumors of efforts to be made to move the town-hall from its old place, which aroused great wrath; and both south village and 'Street' took it hard that part of the men of the distriets to the north had favored a proposition to be set off to an adjoining town. The weak side of human nature came out as well as the strong in the numerous jealousies and bickerings. Following the earefully arranged programme or warrant, from which there conld be no departure, beeause ample warning must be given of every measure proposed, item after item was eonsidered, - a ehange here in the course of the highway to the shire town; how mueh should be raised by taxes; the apportionment of money among the school districts; what bounty the town would pay its quota of troops for the war; a new wing for the poor-house; whether there should be a brilge at the west ford. Now and then eame a touch of humor, as when the young hushands, married within the year, were elected field-ilrivers, - officers taking the place of the ancient howreeres. Onee the Monkmator for the time being displeased the merting by his ruling als regards certain points of orker. 'Mr. Moderator,' eried ont an ancient eitizen with a

1 Colonel Horatio Hawks. 
twang in his voice like that of a well-played jew'sharp, 'if it's in awrder, I'd jest like to inquire the price of cawn at Cheapside.' It was an effective reductio ad absurdum. A rustic Cicero, in a town not far off, whom for some reason the physicians of the village had displeased, once filled up a lull in the proceedings with, 'Mr. Moderator, I move that a dwelling be erected in the centre of the graveyard in which the doctors of the town be required to reside, that they may have always under their eyes the fruits of their labors.'

"The talkers were sometimes fluent, sometimes stumbling and awkward. The richest man in the town, at the same time the town-treasurer, was usually a silent looker-on. His son, however, president of the county agricultural society, an enterprising farmer, whose team was the handsomest, whose oxen the fattest, whose crops the heaviest, was in speech forceful and eloquent, with an energetic word to say on every question. But he was scarcely more prominent in the discussions than the poor broom-corn raisers, whose tax was only a few dollars. There was the intrigue of certain free-thinkers to oust the ministers from the school-committee, - the manœuvring of the factions to get hold of the German colony, a body of immigrants lately imported into the factory village to the north. These sat in a solid mass to one side while the proceedings went on in an unknown tongue, without previous training for such work, voting this way or that, according to the direction of two or three leaders.

"Watching it all, one could see how perfect a democraey it was. Things were often done far enough from 
the best way. Unwise or doubtful men were put in office, important projects stinted by niggardly appropriations, unworthy prejudices allowed to interfere with wise enterprises. Business was sometimes blocked by angry disputes over petty questions. Yet in the main the result was good. This was especially to be noted, how thoroughly the public spirit of those who took part was stimulated, and how well they were trained to self-reliance, intelligence of various kinds, and love for freedom. The rough blacksmith or shoemaker, who had his say as to what should be the restriction about the keeping of dogs, or the pasturing of sheep on the western hills, spoke his mind in homely fashion enough, and possibly recommended some course not the wisest. That he conld do so, however, helped his self-respect, caused him to take a deeper interest in affairs beyond himself, than if things were managed without a right on his part to interfere; and this gain in self-respect, public spirit, self-reliance, to the blacksmith and shoemaker is worth far more than a mere smooth or cheap carrying-on of affairs."

Is there anything more valuable among AngloSaxon institutions than this same ancient popular moot, this old-fashioned New England town-meet- Tributes to its ing? What a list of important men can be value.

cited who have declared in the strongest terms that tongue ean utter, their conviction of its preciousness! ${ }^{1}$

1,John Stuart Mill: Representative Government, p. ift, etc. De

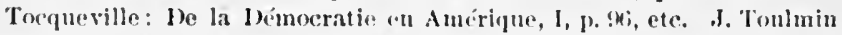
Smith: local Self-Goverument and (entralization, p. 29, ete. May: Coustitutional Ilistory of Vingland, II, P. Hio. liluntschli: (puoted by 11. B. Adams, Germanie Origin of New Fingland Towus. Jefferson: to 
It has been alleged that to this more than anything else was due the supremacy of England in America, the successful colonization out of which grew at last the United States. France failed precisely for want of this. ${ }^{1}$ England prevailed precisely because " nations which are accustomed to township institutions and municipal government are better able than any other to found prosperous colonies. The habit of thinking and governing for one's self is indispensable in a new country." So says De Tocqueville, seeking an explanation for the failure of his own race and the victory of its great rival. ${ }^{2}$ None have admired this thorough New England democracy more heartily than those living under a very different polity. Richard Henry Lee, of Virginia, wrote in admiration of Massachusetts, ${ }^{3}$ - "where yet I hope to finish the remainder of my days. The hasty, umpersevering, aristocratic genius of the South suits not my disposition, and is inconsistent with my views of what must constitute social happiness and security." Jefferson becomes almost fierce in the earnestness with which he urges Virginia to adopt the township. "Those wards, called townships in New England, are the vital principle of their governments, and have proved themselves the wisest invention ever devised by the wit of man for the perfect exercise of self-government, and for its preservation. ... As Cato, then, concluded every speech with

Kercheval, July 12, 1816, and to Cabell, Febrnary 2, 1816. John Adams : Letter to his Wife, October 29, 1775. Samuel Arlams: Letter to Noah Webster, April 30, 1784. R. W. Emerson: Concord Bicentennial Discourse, 1835 , etc.

1 Lecky: History of the Eighteenth Century, I, p. 387.

2 De la Démocratie en Amérique, I, p. 423.

${ }^{8}$ Life of R. H. Lee : Letter to John Adams, October 7, 1779, I, p. 226. 
the words 'Carthago delenda est,' so do I every opinion with the injunction: "Divide the counties into wards!" 1

A vast emigration has gone from New England to the West, until it is estimated that fully one-quarter of the population of the United States is settlement of directly or indirectly of New England the West. origin. Skipping the neighborhood of the Hudson River, which was oceupied by the descendants of the Dutch and the tenants of the old patroon estates, the New England emigrants elose upon a century ago filled up Central and Western New York. Then following the parallels of latitude farther west, hemmed in by the Lakes on one hand, and swerving little to the southward, except when now and then attracted by some point of special advantage, they have penetrated into the Northwest, and are mingled plentifully with the pioneers of the Pacific Coast. Have they earried with them the town-meeting? Grayson, a public character of prominence in the early part of the century, wrote Marlison that in the settlement of the West "the New linglanler's were amazingly attacherl to their own eustom of planting by townships." So it has alwilys been. Wherever they have gone, they have carried the town, and to some extent the town-meeting. It will be interesting to study the result in some of the newer States.

It is, perhalps, a law of Western politial evolution that the connty should precede the system finally adopterl. In it thinly settled country. the comnty organization is simpler and cheaper: it is, in falct, at widely extended township, and resembles in every 
way the tunscipe, except in the absence of the popular moot, which the broad distances to be traversed make impossible. ${ }^{1}$ The IVest may be said to have Ordinance of begun with the Ordinance of 1787 ; for 1787.

though before that scattered settlers had poured across the Alleghanies into Kentucky, Tennessee, and Ohio, no proper political society had been in any way as yet formed. At first, in the Northwest Territory, government was thoroughly centralized, consisting of a governor, secretary, and judges, - all appointed by Congress. ${ }^{2}$ It was not until

Local selfa population of five thousand males had government gathered in Ohio, in consequence of the
in Ohio.

Marietta effort, that a general assembly appeared. Washington County now occupied one-half of Ohio, a centralized system still prevailing: this was intended to be temporary; and whell, in 1802, Ohio became a State, three elective county commissioners took the place of the appointed functionaries, to whom was committed the charge of roads, bridges, ferries, the poor, taxation, sometimes of the schools; in short, a general administrative authority. As Ohio grew, this form of local development in its general features remained. The territory was subdivided into counties, and these again into feebly marked towns; but no town-meeting appeared, as in New England, and no county-meeting, or shire-moot, as in Pennsylvania. ${ }^{3}$ When population thickened at any point into a village, a borough or municipality

1 George E. Howard: Introduction to the Local Constitutional History of the United States, I, p. 149, etc. Baltimore, Johns Hopkins University, 1889. I am much indebted to Professor Howard's very scholarly survey.

2 Howard, I, p. 408, etc. 
took shape, with mayor and couneil. The Ohio fashion was presently followed by Indiana, and later by Iowa, Missouri, and Kansas.

Quite different was the eourse of events further north. Let us look first at Miehigan. "If you seek a pleasant peninsula, look around you," is the motto upon her seal, ${ }^{1}$ and what State In Michigan. of the Union is more beautiful in its situation? Eneireled everywhere but on the sonth by the Great Lakes, the summer heat is tempered salutarily as these breathe aeross to one another; and in the winter the same beneficent neighbors mitigate the severity of the frost. Nobly timbered and wellwatered, Michigan possesses also vast tracts where lie open to the sun the many-acred farms; these "laugh with harvests," which the world nowhere surpasses when "tickled with the hoe." Thus fortunate by nature, the commonwealth has been fortunate in her whole development, as in these latter days population has poured in upon her, and civil society has gradually taken shape. To her Ameriean stoek have been added the best elements of our foreign immigration. Nowhere are the external conditions fatrer: nowlere, perhaps, is there more intelligenee, enterprise, and moral worth. IJer great university has been the soure of lenetits incalenlable; and in symmetrieal subordination to it, wiscely planned and well administered, a public-school system, exceptionally good, affords an erlueation to every alikl within her borders.

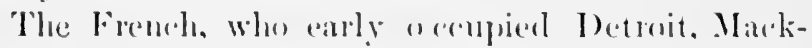

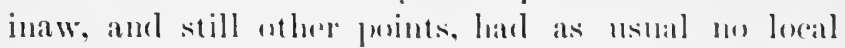
1 "Si peniusulam amunam quaeris, circumspice." 
self-government; hence, no doubt, the feebleness of their colonizing here as everywhere. ${ }^{1}$ Seigneurs held great estates, as in New France in general, and law, when not feudal, was military, all being subject to the convenience of the garrisons. The French settlers enjoyed much personal license, but had no conception of municipal freedom or self-government. "They received, unquestioning, their law from the King and their religion from the priests." 2 The picturesque French era having passed, the British conquerors transferred Michigan, after a brief possession, into the hands of the United States in 1796, when an influx began from Western and Central New York and the States farther east, - in great part, directly or indirectly, a New England stream. At once upon occupying the soil, the settlers showed that tenacious clinging to the town of which Grayson wrote to Madison. A statesman, perhaps too soon forgotten, of New England birth, influenced powerfully the development of Michigan, - Lewis Cass. As territorial governor, from 1813 to 1831, he used his large powers, in the important forming years, to make vigorous everywhere local self-government. "In proportion," said he, "as government recedes from the people, it becomes liable to abuse. Whatever authority can be conveniently exercised in primary assemblies can be deposited there with safety. They furnish practical schools for the consideration of political subjects, and no one can revert to the history of our Revolutionary struggle, without being

1 Lecky: History of the Eighteenth Century, I, p. 387. De Tocqueville: De la Démocratie en Amérique, I, p. 423.

2 Johns Hopkins Cniversity Studies, 1st Series, V, p.9. E. W. Bemis. 
sensible that to their operation we are indebted for much of the energy, unanimity, and intelligence which were displayed by our people at that important crisis. These institutions have elsewhere produced the most beneficial effects upon the character of communities and upon the general course of public measures." 1

Michigan was the first State of the West to adopt the town-meeting, but certain notewortly changes mark the transferrence. In New England of the seventeenth century scarcely any two towns were exactly alike, though the general type was the same. The new towns of the West, however, are duplicates of one another. The Western town-meeting has lost some of the attributes of the primitive moot. Popular enthusiasm is less pronounced in it: it has become a commonplace business-meeting, the ancient democratic elements having yielded in part to a representative plan. Of the officials whom it elects, the highest is the supervisor; and in every county the township supervisors uniting, form the County Board, which possesses large administrative functions. In this form of proeedure, the precedent of New York in 1705 is followed ; and in this we find in its best estate the 'Township-County or Compromise system. We need not be sorry. thinks Professor Iowarl, that the more democratic way has thus yielded in part to "the more efficient and less demonstrative methods of representative govermment. Its powers are commensurate with the needs of a more fully developed society, and there is no reason to regret that the cxces-

1 Quoted by E. W. Bemis: Johns Hopkins University Stmlies, 1st Series, V, 1. 12 . 
sive publicity and obtrusive functionalism of primitive New England have not been perpetuated." 1 By 1827, before its admission to the Union, Michigan had definitely fixed its Township-County organization in which she has been followed since by Illinois, Wisconsin, and Nebraska. "In the States of this group," says Howard, "localism finds its freest expression: the town-meeting possesses powers commensurate with the requirements of modern life $;^{2}$ the primitive and proper nexus between scir and tunscipe is restored; the township is under the county, but represented there. The County Board of Supervisors is the old scir-moot over again. The Township-County system of the Northwest is one of the most perfect products of the English mind, worthy to become, as it may not improbably become, the prevailing type in the United States." ${ }_{3}$

Let us glance for a moment at the career of still another great commonwealth which has come into In Illinois. being, like Michigan, in that vast Northwest Territory of a century ago, - Illinois. ${ }^{4}$ Like Michigan, its first white population was French, whose characteristics at Kaskaskia, Cahokia, and Fort Chartres were no doubt the same as at Detroit. In 1778 , the Northwest Territory was conquered by Virginia, in a military enterprise quite independent of the Continental Congress, from the Eng-

1 Local Self-Government in the United States, I, p. 162.

2 A New Englander cannot help feeling that the Western town-meeting has lost far too much of the character of its prototype of the Eastern States, whatever its gains may have been.

${ }^{3}$ Local Self-Government in the United States, I, p. 158.

4 Albert Shaw : Local Government in Illinois, Johns Hopkins University Studies, 1st Series, III. 
lish, who had enjoyed a brief period of possession. The enterprise and courage shown in the conquest by Major George Rogers Clarke, the commander of the force, were paralleled ly the magnanimity with which, for the sake of the public peace and welfare, Virginia again resigned her acquisition, that it might become the possession of the United States. Illinois, however, had received a listinct Virginia impress, which became more marked as time went on, the population which flowed in being almost exclusively from Virginia and her child, Kentucky, with some infusion from North Carolina. In 1809, Illinois became a Territory, its present limits being defined; in 1818, a State, the settlements thus far being almost entirely in the southern part, and the organization after the southern or County system. The entire administration in each one of the fifteen counties into which the State had been divided was given to three commissioners, elected by the people, to whom the people surrendered all pullic management, with little or no oversight of their own.

But Congress had taken a step which led to important results. In survering the publie domain, Congress hatl eaused the lands to be divided into sections six miles square, to which were given the name of townships. In each township a square mile of land was set off for a school funcl, the township becoming a body corporate and politie for school purposes, anthorized to maintain sohools, and officers necessary for their administration. The Illinois township, was at first far enough from the Xow England township, being in many eases quite minhalited: lont there is much in a name. As popula- 
tion came in, the school served the same purpose which had been served in the earlier day by the meeting-house. ${ }^{1}$ The religious faiths of the immigrants were various, not all of one stripe, as in the New England beginning. Nor was there any compulsory law as to church attendance. Each family, however, settled within convenient reach of the school-house, for which in each township such liberal public provision had been made. Gradually the election districts in which the county officers were chosen came to coincide with the congressional townships, the school-house becoming a convenient voting-place.

In 1820, an important crisis occurred. Missouri having been admitted to the Union as a slave state, Southern immigration was largely diverted thither; while at the same time New Yorkers and New Englanders flowed into Northern Illinois. A fierce struggle set in between North and South over a new constitution, - a struggle which did not culminate until 1847, when it was established that the legislature should make a general law for the organization of townships, the township and not the county to be the political unit, - under which law any county might act when a majority of its voters saw fit to do so. As time has passed, the old animosity has declined, and the State, north and south, has come in general to feel the advantages of the township. Of the one hundred and two counties which Illinois to-day eontains, only twenty-three have refused the Township organization, preferring instead the County system with its very imperfect local self-government. The Illinois system, like that of Michigan, is not 
that of New England; possibly, it is in some ways a better one, the supervisors sitting, each for his township, on the county board, like the ancient reeves in the shire-moot. As regards the great purposes which local self-government may serve, aside from the convenient despatch of business, - to evoke, namely, from the individual citizens who are forced to administer it, a vivid interest in public eoncerns, and to impart to them an education which above all things the freeman requires, - the system is effieient. Upon the map, the great State of Illinois extends, blocked out in its counties, with something of the square precision of a chess-board. In the game which must always go forwarl in a soeiety between the spirit of civilization on the one hand, and the forees of anarchy and disorder on the other, it is cheering to feel that on so fair a field as this at least there can be little doubt as to whieh shall receive eheckmate.

The eondition of self-government in the West need not be set forth at greater length. It is at its best estate in the Township-County system The Town. of Mielhigan, Illinois, Wisconsin, and Ne- slipecounty braska. It is in least satisfalctory form Norhwest. in Ohio, Indiana, Missouri, and Kansas, where the County system frevails, and self-government is not bronght vigomously home to the individunl man through a well-developed township envirommont. As new States have been constituted, and as the older states have gone forward in their growth, varions intermediate types lave been presented. By a law of 1879, for instance, in Missomli, the same option wass offered to the anuties to take, if they 
chose, a Township organization, as was offered to the counties of Illinois. Of the one hundred and fourteen Missouri counties, however, but eighteen have as yet adopted the Township organization. Nevertheless, the tendency is in that direction as population grows dense, and Missouri may be regarded as undergoing a transition. Iowa, Minnesota, and the Dakotas occupy a position intermediate; the township has more extended powers than in Ohio, possessing, for instance, an annual town-meeting for legislation as well as election. The township, however, has no representation upon the county board, which consists of commissioners few in number, sometimes not more than three, sometimes seven or eight, elected at large, and exercising wide control. ${ }^{1}$ It is claimed for this form that it is more cheap and efficient than the more numerous county board made up of township supervisors; on the other hand, it is said to offer dangerous facilities to the formation of "court-house rings." Professor Howard holds it to be less consonant with Anglo-Saxon precedents and a falling short of the highest ideal of social selfgovernment. In the new States of the Pacific Coast and the inchoate societies of the mountain and desert regions which lie back of them, the Township-County plan is approached in those lying toward the North; the County plan in those of the Centre and South.

The County plan prevailed until the Civil War throughout the entire South. We have seen that in Virginia, to such an extent the parent The County
system of the and typical colony of the South, the form South. of society originally established approached

1 Howard : Local Constitutional History, I, p. 158. 
that of contemporary England. There were, namely, vast landed estates, which descended by primogeniture, - a system inevitably resulting in an aristocracy with which lay all social and political prestige, while a great proportion of the population were in a depressed condition. The cultivation of tobacco, stimulating as it did negro slavery and increasing the tendency to scatter, already marked through the prevailing form of land-tenure, made anything like a popular moot impossible. There were, to begin with, few yeomen, small independent farmers, as in New England, the class to whom the moot was almost a necessary appurtenance; in the wide distribution of population, any consensus, whether obtained in formal moot, or through informal talk, was scarcely possible. Great counties were practically the primary divisions, whose officers, justices appointed by the governor, or, indecd, provided for after the manner of a elose corporation, performed all administrative functions with small responsibility to the people.

As the South came forward, Virginia continued to be scarcely less typical than in the early period. Cotton, which grew to be king over so vast a district, as tolnaceo had been in the Old 1)ominion, was equally potent in promoting slavery, a system of linge plantations rather than small holdings, an aristocracy in whose hands should lie all power, and a vast class of poor whites with few of the qualities of frement it was equally potent, too, in diseomaging town life and all forms of the moot. Everywhere thromgln the South and Southwest the County system prevailed, its functionaries qualified by the oligarclay in lwwer 
through some form of appointment or election, but subject to no popular control, and with no shadow of responsibility to any form of folk-moot.

Since the war, however, noteworthy changes have been in progress. In the New South, mining, commerce, and manufactures have largely thrust into the background the old plantation life. Slavery is abolished. A more democratic spirit prevails, and as a natural consequence the disposition grows active to cherish the safeguards of Anglo-Saxon freedom. First among such safeguards the public school lifts its head. The school system of the North is rapidly making its way in the South, and "is likely to prove the model for the entire transformation of the social body." 1 In Virginia, Kentucky, Texas, and Tennessee, the people vote school taxes and choose school officers; in Alabama the township has been formally instituted mainly for this purpose. The school district, with its belongings, is being firmly driven by the new democratic spirit into the ancient Southern framework, and plainly is an entering wedge for local self-government on a larger scale. Clearly, the school-meeting is to be a preparation for the townmeeting. ${ }^{2}$ In the salutary changes, Virginia, as ever, is a leader. In 1869, in days of disfranchisement, the Township-County system was projected for her; and promptly repudiated, in 1874 , when the State was restored to herself. In what was substituted, however, the best features of the rejected plan were retained, all terminology being avoided which smelt of the "carpet-bag." Each county was divided into

1 Howard, Local Constitutional History, I, p. 237.

2 E. W. Bemis, quoted by Howard, Loc. Const. Hist., I, p. 237. 
not less than three divisions to which the name of "magisterial districts" was attached, the abhorrent word "township" being ignominiously cast out. Each such district has its elected supervisor among other functionaries, and the supervisors constitute, after the best preeedents, the county board. Again, each larger district is subdivided into school districts. West Virginia and North Carolina show a similar change. ${ }^{1}$

As Mr. Bryce summarizes, the Union may be divided into three zones, - northern, middle, and southern. The northern zone extends from the confluence of the Yellowstone with the Missouri eastward to the Bay of Fundy, and includes the Dakotas, Minnesota, Wisconsin, Illinois, Michigan, and New England. 'There the town-meeting in preponderant activity is the unit of loeal govermment. The middle zone stretehes from California to New Jersey and New York along the fortieth parallel. This is characterized by the Compromise system; in a part of the States one sicle of the organization preponderating, in part the other. All, however, are alike in this, you canmot lose sight for a moment of the larger or smaller area. The third zone inclutes all the fontlern States. Ilere the aounty is predominant, though here and there sehool distriets, and even townships, are growing in significance.

The town-meeting, he continnes, has been not only the somre, but the selool of demoxeracy; but the atetion of so small a mit needs to be supt Adsantagen of plemented, perhaps in some points to he die Towneldipsupervised, by that of the eomnty; and in

11loward, I, p. $233 . \quad 2$ Bryce: Ameriean Commonwealth, 1, p. 582. 
this respect the mixed system of the Middle States is deemed to have borne its part in the creation of a perfect type. An assimilative process has been going on for some time, tending to the evolution of such a type all over the United States. In adopting the Township system of New England, the Northwest States have borrowed some of the attributes of the County system of the Middle States. The Middle States, moreover, have developed the township into a higher vitality than it formerly had among them. Some of the Southern States are introducing the township, and others are likely to follow as they advance in population and education. It is possible that by the middle of the next century there will prevail one system, uniform in its outlines, over the whole country, with the township for its basis, and the county as the organ called to deal with those matters, which, while they are too large for township management, it seems inexpedient to remit to the unhealthy atmosphere of a State capital. ${ }^{1}$

As to efficient local self-government, then, the proper primordial cell of our body politic, the rural communities of America, may be said to Examination of urban America. promise well, on the whole: while shortcomings abound, improvement may be anticipated, with a good prospect of a desirable outcome. But as yet we are far from having finished our examination. At countless points in the West population has grown dense, and a form of government at once assumed in which the individual discharges himself of a great part of his responsibility.

1 Bryce: American Commonwealth, I, pp. 591, 592. 
In the older States along the seaboard, municipalities have inereased vastly in size and number, with a similar result. One quarter, nearly, of the sixty millions of America are dwellers in cities; in some States, as New York, more than one-half, and the proportion of the urban to the rural poput- $\begin{gathered}\text { Growtl and } \\ \text { multiplication } \\ \text { of cities }\end{gathered}$ lation is constantly increasing.

It is not necessary to regard this fact as a calamity. In Australia, the proportion of the urban to the rural population is far larger than with us and exeites no alarm. Sydney and Adelaide alone contain about thirty-five per cent of the people of their respective colonies, and Melbourne a still higher per cent. In each ease "the population of the colony, generally speaking, gains, from the concentration in the capitals, in education, in power of reereation, and in many of the matters which make life most pleasant. The effeet must be a quiekening of the national pulse, and is already, in fact, visible in the brightness and high intelligence of the Australian people." The Austrillians contend that the people are not drawn from produetion, but only eoncentrated for business and soeial life, and that the whole eivilized world is eoming to this. Americans have not as yet learned to take so rheerful a view as this, ehiefly from the faret that the problem of eity government las so far not been mastered.

"When a eommunity of moderate size, which has gone forward umler its town-meeting, at lengrth inereases so far as to be entitled to a eity charter, the day is commonly hailed with ringing of bells and salutes of cannom. Is it rally at time to be rejoiced

'Dilke: l'roblems of (ireater liritain, p. $4 ! r$. 
over? What does it mean? This - that the people cease to govern themselves: once a year they choose those who are to govern for them. Instead of the town-meeting discussions and votes, one must now spend only ten minutes perhaps in a year: no more listening to long debates about schools, roads, and bridges; one has only to drop a slip of paper containing a list which some one has been kind enough to prepare for him, into a box, and he has done his duty as a citizen. In the most favorable circumstances, the mayor and common council, representing the citizens, do the work for them, individuals being discharged from the somewhat burdensome, but so quickening and educating duties of the moot. That things are constantly tending to this is one of the most perplexing and threatening features of our system. 'The assuming of a city charter is said to be an almost complete abnegation of practical democracy." 1

The government of cities, says Bryce, is the one conspicuous failure in the United States. ${ }^{2}$ To what Their govern- shall we turn to save ourselves? is the quesment hitherto
a conspicuous failure. cry of agony and despair being stronger in our metropolis, New York, than anywhere else. The able editor lashes the respectable citizen for his indifference to politics, and to such charges are made replies like this: "It is sheer nonsense to say to a modern New York merchant, "Take an interest in politics, attend primaries, find men to accept office, canvass your acquaintances, and watch the men elected.' His mind must be occupied from morn till night with

1 F. W. Allen, in the New York "Nation," May 29, 1866.

2 American Commonwealth, I, p. 608. 
business; he will go to the wall else." And still another expresses the thought more fully: "There is a tendeney to differentiation in modern society. At first all had leisure for politics; we were a nation of farmers, planters, and a few shopkeepers. Our merchants then had leisure. Now, life is much more intense through steam and the telegraph. If a merchant attends to politics, he perils his success in business. If he gives time to it, he is ruined. It is the great law of division of labor, not neglect of duty, which has made politics a trade. Polities in every land is in the hands of a leisure class. Through a bad system of representation we exclude our best men: our leisure class are the wretches."

In the past days of our race, as towns have grown into eities, exchanging the borough-moot for the board meetings of the mayor and aldermen, the people have become indifferent to freedom. We are now exposed to the same danger, and the dimger is complieated for us from the circmmstance that there has been poured upon us a flood of immigrants of all races, who, without a particle of discipline, hatre heen suffered to laty Jobl of our ordered Anglo-saxon liberty.

While the rlistressing picture of municipal misrule is unrolled before our eyes, especially in New York, but also in every large eity of the country, there is one hopeful circumstance. The Ragerness to danger is fully felt, and great energy is direeted to the diseovery and applieation of remerlies. In the extravagance, corruption, rapacity, which threaten to destroy the social fabric, the strongest minds come hurrying with appliances, as in a con- 
flagration, the vigorous men run with bucket, axe, and rope. I have a collection of suggestions made during recent years. Says Mr. Grace, late mayor of New York: "In our municipalities, the people have never been permitted actually to realize the dignity and responsibility of self-government. They have practically been denied the right to that experience, which brings with it the only political education that renders a people capable of self-government," and he cries out against corrupt legislative interference as the main source of evil. Says the New York Nation, "The evil is in giving power into the hands of a penniless, ignorant proletariat; political power lies not in the hands of the people, but the mob. Democracy hardly exists in these communities," and a plan is propounded for securing influence to property and intelligence. Says the International Review, "The government of a modern city is analogous to the administration of property, to that, for instance, of a railway or a bank, and requires to be cared for in similar ways." 1

One of the latest and certainly the most authoritative voice that has considered the matter, is that of

Views of Hon. Seth Low.

Hon. Seth Low, president of Columbia College, and late mayor of the large eity of Brooklyn. He finds, as do all, a continually disturbing factor in the immense tide of immigration, eighty per cent of the population of New York being either foreign born or the children of foreign parents. In the growth of American cities, everything must be created or arranged anew; the marvel really is not so much that they are open to 
criticism for many defects, but rather that results so great have been achieved in so short a time. Charters have been framed as though eities were little States. Americans are only just learning, after many years of bitter experience, that they are not so much little States as large corporations. To this mistake have been due many of the errors in eity management. The aim has been to make a eity government where no officer by himself should have power to do much harm, and the natural result was to create a situation where no officer had power to do much good. Men are coming to see that cities are large corporations; and as such, one man in them must be given the power of direction and the ehoice of his chief assistants : power and responsibility must go together from the top to the bottom of every successful business organization. In the charter granted in 1882, to the great city of Brooklyn, then of seven hundred and fifty thousand people, the mayor is entirely responsible for the eonduct of the city govermment on its executive side, and equipped with powers necessary to discharge his trust. Mr. I ow believes that the ideal eity charter should be founded upon the theory of separation of the legislative and executive functions; that the board of aldermen should have no more power of interferenee with the executive than the Inouse of Representatives has ; that the mayor shomld have the power of appointment and removal of exeentive officers during the time for which he is responsible for the government; that there should be constitutional restrictions as to the incurring of clebt: and that the power of the State lecrislature to interfure in municipal matters should be reduced to a minimum. 
He says, hopefully and manfully: "I have a feeling that our progress, if slow, is steadily in the direction of betterment. I do not expect to see the history of the next twenty years in the affairs of our cities repeat all the scandals that have marked the past twenty years. It is not strange that a people conducting an experiment for which there is absolutely no precedent, should have to stumble towards correct and successful methods through experiences which may be both costly and distressing. I see no other road towards improvement in the coming time, but I think it certain that in another decade we shall look back on some of the scandals of the present in city government with as much surprise, as we now regard the effort to control fires by a volunteer fire department, which was insisted upon in New York until within twenty years. In other words, I take no gloomy view of the situation. I see nothing in the general condition of affairs which is absolutely incurable, unless it be the unwillingness of the people themselves to choose their local officials along divisions on local lines. I confess that it is here that the problem appears to me the most difficult. I hope for good results in this direction, however, from the growth of sentiment in favor of civil service reform, whereby patronage shall become less and less powerful in the determination of election contests; from legislation which, in controlling to some extent the cost and methods of conducting canvasses, may reduce to a minimum the mischief wrought by the improper use of money. I do not expect to live long enough to see the government of cities in America anything other than a pressing problem, but it is a problem everywhere." 
Above all, Mr. Low's experience has inspired him with confidence in, not with distrust of, the people. "Because there is scum upon the surface of a boiling liquid, it does not follow that the material or the process to which it is subjected is itself bad. Universal suffrage, as it exists in the United States, is not only a great element of safety in the present day and generation, but is perhaps the mightiest educational force to which the masses of men have ever been exposed. In a country where wealth has no hereditary sense of obligation to its neighbors, it is hard to conceive what would be the condition of society, if universal suffrage did not compel every one having property, to consider, to some extent at least, the well-being of the whole community." 1

As regards local self-government, then, there is no ground for hopelessness as to the future of America. In rural communities, the popular moot, Grounds for a adapted to our new conditions, but with hopeful view. its administrative effieieney and its salutary clueative power not lost, persists in New England, is spreading West, and even South. With respect to cities, while the embarrassments are great, there is no reason for feeling that a good way to govern them will not some day be foumd. A town-meeting plan is unquestionally quite inadequate; lut whatever be the method, why need we doubt that it can safely

Bryee: American Commonwealth, I, Chap, I.1I (chapter by IIon. Seth Iow), "The l'roblem of Municipal (iovermment in the Lnitud

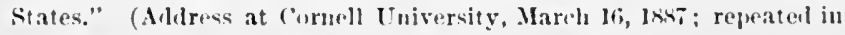
substance at Johns llopkins (niversity.) 
rest on a basis of universal suffrage? If the folk vote, the folk will also, in some way, moot the merits of candidates and of questions upon which it must pass judgment. If the primordial cell is sound, the body will not perish.

To candid foreign eyes we offer no unpromising spectacle. "Local self-government will doubtless sometimes go wrong, but so too will government officials. A few mistakes are a small price to pay for freedom. Compare France and America. The agitation of France is aggravated, if not caused, by centralization. Under every régime Paris has been France; the provinces have been powerless; the best statesmen of France are making every effort to decentralize. Centralization emaseulates public spirit, induces a careless indifference to the welfare of the community, takes away the sense of responsibility in local affairs, tends to produce a degrading subserviency to the powers above, and is in every way destructive of that manly feeling of individual freedom with combined action which has hitherto been held as the glory and boast of our English institutions. Compare with France the system of the United States, where democratic and local institutions have acquired a development and ascendency elsewhere unknown. No doubt, a thousand faults may be discovered. The Tammany ring, the iniquities of the New York municipality, venality and corruption in various forms, may be raked up and combined to form a hideous picture. But turn to the other side. Where is there, on the whole, a more law-abiding people? Where is individual liberty more enjoyed? Where, indeed, has the true 
CONDITION OF THE AMERICAN POLITY. 307

English principle of local self-government been dereloped with such success?" 1

1 Contemporary Review, 34, p. 678, etc., art. "Self-Government in Towns," by J. Allanson Picton. For a hopeful view of the prospects of the [nited States, and also of Canada and Australia, as regards the disappearanee of political corruption, see Dilke: Problems of Greater Britain, p. 103. 


\section{CHAPTER XVIII.}

\section{THE FUTURE OF ANGLO-SAXON FREEDOM.}

THE progress of Anglo-Saxon freedom has been outlined in these pages through eighteen hundred years, from the Germans of Tacitus to the present moment. It is now in place to consider what may fairly be anticipated for it in years to come, and to inquire whether the generation of English-speaking men now upon the stage is doing what may reasonably be expected of it, in view of the opportunities it enjoys and the responsibilities with which it is trusted. Though Anglo-Saxon freedom in a more or less partial form has been adopted (it would be better perhaps to say imitated) by every nation in Europe, but Russia, and in Asia by Japan, the hopes for that freedom, in the future, rest with the Englishspeaking race. By that race alone it has been preserved amidst a thousand perils; to that race alone is it thoroughly congenial; if we can conceive the possibility of the disappearance among peoples of that race, the chance would be small for that freedom's survival. They are the Levites to whom, in especial, is committed the guardianship of this ark, so infinitely precious to the world. In no century of its career has the band understood so well the sacred character of its responsibility, and looked with such love upon the trust it was appointed to defend. 
One of the latest and best of historians believes it possible that the two branches of English-speaking men will always remain separate political

exis wedictions of existences, - that the older, indeed, may sometime again break into two or more nations. He predicts, however, that all the wide spread of the Englishspeaking race. will become one in spirit, and before fifty years have passed, change the face of the world. Two hundred million of English-speaking men he beholds with prophetic glanee in the valley of the Mississippi, fifty million in Australia, and a growth commensurate in the other vast regions which our far-roaming brethren have possessed. Before this enormous increase, other peoples are destined to sink into the second rank. The inevitable issue is to be that the primaey of the world will lie with us. English institutions, English speech, English thought, are to become the main features of the political, social, and intellectual life of mankind. ${ }^{1}$

A pamphlet widely cireulated during the past decade contemplates the future of the English-speaking race and their institutions with still more entlusiasm. $^{2}$ In a hundred years, says Mr. Zincke, the United States will have a population of $800,000,000$; Canada, 64,000,000; Australia, 48,000,000; South Africa, 16,000,000; Great Britain and Ireland, 70,000,000: altogether, in his estimate, there will be $1,000,000,000$, sulstantially the same in language, institutions and ideals. The United States will have overflowed southward and into the islands of the

1 J. R. (ireen: History of the English l'eople, IV, 1. 270, ett'.

2 liy Rev. F. Barham Zincke, Chaplain to the Queen; reviewed in New York "Nation," April 5, 1883. 
Pacific. Our limits will touch those of Australia and New Zealand, which on their side, too, will flow out. In South Africa, also, the "Englishry" will have wonderfully multiplied and poured into the regions lying northward, which Livingstone and Stanley have laid open and are proving to be habitable. The flower of the species, therefore, says the writer, who has no mean idea of our stock, will have come, in the course of a century, to occupy the fairest parts of the planet. What will be the nature of the society which one hundred years from now will be thus widespread? It will be fundamentally the same in manners and ideas, with slight differences due to climate and soil. Mr. Zincke has made himself well-known in England by his strenuous opposition to "landlordism," and his able advocacy of "peasant proprietorship." The immense estates, consisting of many thousands of acres, sometimes almost of whole counties, which exist in England, Scotland, and Ireland, where the owners are often absentees, scarcely seeing their lands from one year's end to another, and where the occupants are merely tenants, at the will of the landlord as regards rent, and liable to ejection at any time if he should see fit to turn his pasture into a game preserve, or prefer to have a great tract occupied by farms changed into a lordly park, these immense estates, our writer regards as producing immense evil for the population. Let them be broken up into small holdings, upon each one of which shall live, as in days of yore, the yeoman, independent in spirit, because he feels that he owns the land he tills; patriotic, for he has a stake in the country that bore him; intelligent and energetic, 
because in the exercise of the thousand rights and responsibilities which belong to a condition of free proprietorship, the mind becomes in every way stimulated and trained. Let us have back again, urges Mr. Zincke, our old English yeoman; or, as he does not hesitate to say, let us have the American farmer, which is the same thing. He feels sure that this is the type which will come to prevail; and in the great "Englishry," the billion of English-speaking men who a hundred years from now are to occupy the fairest portions of the earth, the Ameriean farmer, in his idea, will furnish the ty je of the new society. There will be few savages, no serfs, or slaves, - not many drones or Sybarites, - none withont civilization. All will be able to read and write, have homes of their own, hold enough land to yield to intelligent industry a good support. They will have no social or political superiors; they will manage for themselves their own business, $-A$ braham Lincoln's "government of the people, by the people, and for the people." Society, legislation, administration of affairs, will be to them a most effective means of education. At the head of all, though not necessarily in one nationality with the rest, will stand the United States, our President the foremost man, Ameriean ideas (which, as Horace Walpole saw, and we may now so plainly see, are the oldest English ideas), regulating the whole vast society. "The dream is rather wild, perhaps," says the Nation, "lont we doubt if any one can read it, withont, when he lays it down, finding it very hard to furnish a good reason for doubting it."

Without leing over-simguine, we can entertain 
anticipations as glowing as these. Quite in the spirit of the writer whose views have just been summarized, Mr. Gladstone declared at Paris, September 8, 1889: "A hundred years ago, the English-speaking population of America amounted to $3,000,000$; it now amounts to $60,000,000$, and we are told with every appearance of probability, that in another hundred year's it will amount to $600,000,000$. Under these circumstances, I wish to recognize the right of America to be considered as being prospectively, and even now to a certain extent, - for we have not in our small islands yet quite touched $40,000,000,-$ I wish to recognize the prospective and approaching right of America to be the great organ of the powerful English tongue."

Of what type are the men to whom the dominion of the world is about to be so largely committed? Blood of the The tongue they speak is English, strengthrace still pure, ened and enriched by infusions from every
though enriched by for-
eignadmixture.

contact. The freedom in which they have been nursed is English, though here and there in their institutions are features which have been caught from races outside. Can it also be said that the stock is still fundamentally English, however large may have been the inpouring into its veins of foreign blood? When among our kin beyond the sea it was urged not long since that in the people of England, the Anglo-Saxon had been superseded, - that Celt, Frank, Scandinavian, Hollander, Huguenot, - the multitude of invaders and immigrants through a thousand years, - had reduced the primitive element to insignificance, it was well replied by Mr. Freeman :- 
"In a nation there commonly is a certain element which is more than an element, something which is its real kernel, its real essence; something view of Freewhich attracts and absorbs all other ele- man. ments, so that other elements are not co-ordinate elements, but mere infusions into a whole which is already in being.... If after adopting so many. . . we remain Englishmen none the less, surely a new witness is brought to the strength of the English life within us, - a life which ean thus do the work of the alehemist, and change every foreign element into its own English being." 1

A similar statement miglit be made as regards America. From the twenty thousind Englishmen who between the years of 1620 and 1640 eame to New England, it is estimated that one quarter of the sixty millions of our present population are derived. From the English who settled elsewhere in the Thirteen Colonies, an equal, perhaps a larger, increase has proceeded. The stranger, indeed, has been with us from the beginning: Frenchman and Spaniard preceded us; Celt, Swede, Dutchman, and Cierman came with us in the earliest ships. The overflow of Emope, and latterly even of $A$ sia, has been poured upon us in an immotion; yet the English stock remains, - " the clement which is more than an element, the real kernel, the real essence; something which attracts and alworts all other elements, so that other elements are not coordinate, but mere infusions into a whole which is already in heing." That this is true, the testimony can be cited of witnessess who camnot be gainsaiti.

1E. A. Freeman: Four Oxford Lectures, 18si, p. 80. 
Said Matthew Arnold in the Nineteenth Century, in one of his latest papers:-

"I have long accustomed myself to regard the people of the United States as just the same people with ourof Natthew selves, - as simply the English on the other Arnold. side of the Atlantic. The ethnology of that American diplomatist who, the other day, assured a Berlin audience that the great admixture of German had now made the people of the United States as much German as English, has not yet prevailed with me. I adhere to my old persuasion; the Americans are English people on the other side of the Atlantic."

Says another gifted Englishman, R. A. Proctor, whom also the world has lately lost, in one of his last Of R. A. utterances: ${ }^{1}$ "Most Englishmen and nearly Proctor. all Americans take an entirely wrong view of the kinship of the two races. They seem to look upon it as something remote, where in reality (as science views it, and as common sense should view it) it is so close that the biologist regards it almost as identity. They speak of Britain as the mother-country, where in reality Americans are as yet but a community of Europeans, chiefly Britons, who have as but yesterday occupied their new home; they can no more be regarded as a distinct race than the sparrows who just now so plague the American farmer are to be regarded as a distinct family from the twitterers in our London streets. .. . I might as reasonably look upon my fellow-countrymen on the other side of the Atlantic as of a different race, because I happen to have lived a few years in America, as the American

1 In the Louisville “ Courier-Jourual," the Chicago "Inter-Ocean," etc. 
of to-day regard his cousins in the old home as another people, because a short time ago (yesterday in race-history) some few came out from Britain here, and many have since followed them.... I have had better opportunities than most men of comparing the two nations; and I profess I find the difference between them even less than I should have expected from the difference in the conditions under which the two nations have subsisted during the last few generations. What I supposed, in the incompleteness of my first few years' information, to indieate characteristic differences, I have found to be no more characteristic (in the national sense) than the differences I find in the ways of my friends, the Smiths, who live in the country; in those of my friends, the Browns, who live by the river-side; and to those other friends of mine, the Robinsons, who pass the greater part of their time in London.... . If there is life in the good old English blood still, it is good for America, since it is thence the life of the American race came. If Americans have in them the will and power to thrive, it looks well for their English kindred, sinee they are of the same blood. Creat Britain and America have diverse futures - even though the old comtry may Ix: able to shake off the dead-weight which the new country left behind it. But it is sure and eertain truth that mutual insults imply common fants, while mutral esteem indicates that each nation respects itself and hiss faith in its own great future."

Still more signifieant than these declarations are the words of Bryce: "Any one can see how severe a strain is put on democratie institutions by of James the influx every year of half a million of Bryce. 
untrained Europeans, not to speak of those French Canadians who now settle in the northeastern States. Being in most States admitted to full civic rights before they have come to shake off European notions and habits, these strangers enjoy political power before they either share or are amenable to American opinion. Such immigrants are at first not merely a dead-weight in the ship, but a weight which party managers can, in city polities, so shift as to go near upsetting her. They follow blindly leaders of their own race, are not moved by discussion, exercise no judgment of their own. This lasts for some years, probably for the rest of life with those who are elderly when they arrive. But the younger sort, when, if they be foreigners, they have learned English, when, working among Americans, they have imbibed the sentiments and assimilated the ideas of the country, - are thenceforth scarcely to be distinguished from the native population. They are more American than the Americans in their desire to put on the character of their new country. The peculiar gift which the republic possesses of quickly dissolving and assimilating the foreign bodies that are poured into her mass, imparting to them her own qualities of orderliness, good sense, self-restraint, a willingness to bow to the will of the majority, is mainly due to the all-pervading force of opinion, which the new-comer, so soon as he has formed social and business relations with the natives, breathes in daily till it insensibly transmutes him. Their faith, and a sentiment of resentment against England, keep up among the Irish a body of separate opinion, which for a time resists the solvent power of its American 
environment. But the public schools finish the work of the factory and the newspapers. The Irish immigrant's son is an American citizen for all other purposes, even if he retain, which he seldom does, the hereditary anglophobia. ${ }^{1}$... Recent immigrants have as yet affected American society but little, save that the Germans have brought in a greater fondness for music, for the drama, and for out-of-door life in the cities. I greatly doubt whether the influence of the immigrants will be much more powerful in the future, so strong is the native type of thought and customs, and so quickly does it tell on the new-comers." 2

Here, finally, is the testimony of an elevated and brilliant mind. The chief impression of Sir Edwin Arnold, the poet of the "Light of Asia" orSir Edwin and editor of the London Telegraph, when Arnold. in America, was "of the absolute practical identity of manner, mind, and national life between our two countries." Said he :-

"I have found myself everywhere in a transatlantic England. I do not say that in any foolish idea that to be 'quite English' is a point of perfection. You may just as well remark that we resemble you; hut there the fact is that bygone writers must have exaggerated most alswrdly the supposed distinctive American traits, or else that you have ceased to exhibit them; for I have asked myself a hundred times, wandering in your streets and journeying on your railways, 'Am I really in the New World, or dreaming of it in the old one?' Half an American as I am, by marriage and by sympathies, I must comfess that it

\footnotetext{
I American Commonwealth, II, p. 328.

Ibid., p. 6ĩs, note.
} 
has been wholly delightful to observe this unmistakable and minute identification of the races, and it fills me with hope that whatever other nations may quarrel and come into armed conflict, America and England - vainly divided by the ocean - will by and by establish an international tribunal composed of the worthiest and best-trusted men on either side, and will refer to their judgment under the laws of right and reason - without appeal - every question which threatens to disturb the natural alliance that, in my opinion, furnishes the very best hope of mankind." 1 Immigrants, says Mr. Bryce, have been speedily assimilated: so it has been throughout our history. The Anglo-Saxon stock has been made rich and strong by a score of crossings with the most vigorous and intellectual of modern races, but it remains, Identity of English. speaking men as illustrated at the Colonial Exhibition of nevertheless, Anglo-Saxon. In 1886, at the great Colonial Exhibition in London, what especially struck the American visitor was the identity with his own civilization of the civilization represented in the products set forth; and the similarity to himself of the English-speaking men who had gathered there, though they came from the farthest corners of the world. Such clothing we wear; in such cars and coaches we ride; with such appliances we, too, mine, work the soil, sail the sea, make music, and teach the young idea how to shoot; in the paintings of towns at the antipodes, which sometimes were hung on the walls, the streets looked like those of any

1 Unlike the authorities that have been cited, Sir Charles Dilke finds the differences considerable between the populations of the United States and the British empire. Problems of Greater Britain, pp. 90, 696. 
American town; the frontiersman's hut in the remote clearing, as the model showed it, was a reproduction of the log-cabin of Dakota or Kansas. If the American fell into talk with a group pausing in an aisle before some attractive object, though one might be from New Zealand, another from the Falkland Islands, a third from Natal, and a fourth from Athabasca, a close spiritual and intellectual relationship was at once developed. All had read to a large extent the same books, been trained in the same religious faith, disciplined and made strongly virile by that priceless polity, so free and yet so carefully ordered, which had been inherited from Anglo-Saxon ancestors, or thoroughly assimilated through contact with Englishmen.

"Should you know," said the American, "that my home is in the valley of the Mississippi?"

"By no means," was the reply; "you seem to me like my neighbors in Auckland."

And yet it was two hundred and fifty years since the ancestor of the American had left his home in Kent to go to the New World, and the New Zealander had never left his island until he took ship a month before for London. "You seem like my neighbors," also could say the man from Cape Town, from Fort Farry, from luget Sound, from the gold fielils of Ballarat. "You might all come from this or that English comnty," satil a londoner who had joined the groul]; "you are no more diverse from one another, or from us, than the man of Yorkshire from the man of Dorset, - the Cumberland shepherel from the Laderestershire farmer." Marvellous, inderd, wass the display of resources in the Colonial bxhibition: 
profound was the impression received of the vastness of the empire of England, and of the productiveness of the territories scattered so widely in every zone. Dots of islands, of which one had scarcely heard, had each its nook, filled with sugar-cane, palm-leaves, feathers of the bird-of-paradise; or with tasselled maize and the tanned hides of mighty oxen; or again with sealskins, the tusks of the walrus, and snowshoes bound together with the sinews of the reindeer, - according as the situation of the islet was under a torrid, a temperate, or an arctic sun. At the same time, in spacious apartments or far-stretching halls, the larger dependencies made each a majestic showing of results, when lands endowed with fertility, stretching under favorable heavens, respond with products overflowing in abundance to the cherishing of civilized men. Full of interest, however, though the display of material wealth was, a far deeper interest lay in the fact that these men, so widely sundered in all the four quarters of the earth, were flesh of one another's flesh, and bone of one another's bone, speaking one tongue, disciplined by the same agencies, judging by the same standards, aspiring to the same ideals. Substantially, they were identical with one another, - identical, too, with the American, - all with blood enriched by infusion from scores of the choicest races, but not changed in frame or speech or soul from the champions who, under Alfred, or Earl Simon, or Cromwell, or Washington, or Lincoln, fought to sustain Anglo-Saxon freedom.

Not only does the English-speaking race remain substantially one, but it has never been stronger or better than at the present hour. The stock that has 
colonized so widely, that rules with so little discord the two hundred and fifty millions of India, that fought through in America $\begin{gathered}\text { } \\ \text { never stronger } \\ \text { or better than }\end{gathered}$ those dreadful four years of civil war, - ${ }^{\text {now. }}$ the stock which, in spite of its rapacity and self-seeking, has furnished such types of fortitude, steadfastness, consecration of high powers to noble ends, as Livingstone, Stanley, Gordon who died at Khartoum, John Bright, Abraham Lincoln, — as to such a stock it may well be said that it has undergone no degeneraey, even though we compare it with the men of '76, the generation of the Pilgrim Fathers, the Englishmen of the day of Elizabeth, or those who followed Henry $\mathrm{V}$ to the field of A gincourt.

Whatever strength and virtue the English-speaking man of to-day can summon up, he undoubtedly needs. No age has been without its lowering dangers, and perplexities apparently inex- $\begin{gathered}\text { The embars- } \\ \text { rasments } \\ \text { that beet }\end{gathered}$ tricable; probably no age will ever be without them. In the gymnasium of human experience, such lets and hars are the applianees through exercise with which the souls of men are to be made strong. Our age has them to so full an extent that we feel sometimes we are likely to be erushed. Certain embarassments are common to us and to the whole civilized world; as, for instance, the troulles arising from the unsatisfactory re- dangers.

lations between labor and eapital, from plutoeracy, from overgrown corporations, from the encroachments of eeclesiastieal power in directions quite heyond its proper domain, from intemperance, from licentiousness, from seltishness of at thousand kinds.

Other occasions for anxiety are peeuliar. Canada 
asks what is to be done with the French of Quebec?

Colonial em.

Australia feels that she sits beneath the barrassments. shadow of a constant peril from the four hundred million Chinese, who, no longer cherishing isolation, have become enterprising and aggressive, and, if unopposed, are quite able and quite willing to overspread her lands with a flood that would make them Mongolian rather than Anglo-Saxon. England is full of agitation over the Irish question. "Let IreEmbarrass- land be satisfied with her present relations ments of England.

to us," say the Unionists; "with an ample representation at Westminster, with complete tolerance of Catholicism, with every avenue thrown open so that no bar exists in the Church, Army, Navy, or anywhere to prevent an Irishman from reaching the highest positions, with Anglicanism disestablished upon her soil, and the best will on our part to put an end to all abuses, which we confess with shame have existed in centuries that have passed; - when so much has been done, and the disposition exists to do so much more, why cannot Ireland be satisfied with the present bond?" On the other hand arises the Irish clamor for practical independence; while radicals of a less extreme type exclaim: "Let us give Ireland local self-government; let her have a Parliament of her own for her own affairs, and be connected with us by a tie similar to that which connects a State with the Federal Union, in America. If it follows from this as a necessary consequence that Scotland and Wales must also have local independence, and each its own legislature, so let it be; the time demands a certain reconstruction of the British empire. No important thing 
would be sacrificed, and a hundred important things would be gained, with the coming to pass of Imperial Federation. Let not only Ireland, Scotland, and Wales stand locally independent, but also Canada, New Zealand, and Australia; and let the Parliament at Westminster become a congress competent to deal with imperial questions only, each matter of limited interest being remanded to the assembly of the district concerned in its settlement." In such a readjustment of the British polity, say the Home Rulers, nothing of moment would be sacrificed; every time-honorer heirloom of the constitution might be thoroughly preserved. The monarehy ean stand; perhaps even the House of Lords, though this is more uncertain; nor need disestablishment of necessity follow. Simply the empire would be reconstructed after a fashion which would adapt it to the present situation and to present ideas, - all so widely different from the situations and the ideas of the times which have preceded ours.

America is no less beset witl questions of difficulty peculiar to herself. What does justice to the negro demand, and how shall it be secured to him, while at the wame timehim, while at the same time our institutions are helil safe, - institutions which presuppose as a first condition of their existence that an intelligent people shatl administer them? Can the civil service be reformed, and legislatures, State and Federal, he redeemed from corruption and inefficiency? What safeguards can be thrown almout the public schools, indispensable cradles of good citizenship, institutions of fundamental importance, at uo time in our history too zealously cherished, and at the present hour boldly 
attacked by the power which so often has been the most formidable foe of freedom? What dikes can be erected against the undesirable foreign flood, which, pouring in yearly in volume always increasing through the unobstructed sluices of our seaports, seems likely so far to dilute our blood as to make it unequal to the task of sustaining Anglo-Saxon freedom? Said Lowell once: "I remember a good many years ago, M. Guizot asked me how long I thought the American Republic was going to last. Said I, 'M. Guizot, it will last just as long as the traditions of the men of English descent who founded it are dominant there.' And he assented. And that is my firm faith." Can we be quite sure that the traditions of the men of English descent will remain dominant? Mr. Bryce, in a passage already quoted, speaks confidently of the vast assimilating power possessed by the American people, and makes light of anticipation of evils to arise from an overtaxing of that power. Perhaps he is too confident. Who can help being daunted before present facts? An American minister to a foreign court declares in Berlin without contradiction that the ideas of Germany have displaced those of the Anglo-Saxon world in America!1 A Philadelphia journalist thinks a trip from the seaboard to the Mississippi enough to disabuse one of the idea that this is an Anglo-Saxon nation. ${ }^{2}$ An intelligent American citizen of foreign birth claims also that our whole civilization is at present German, rather than English. "The republican spirit is German rather than English. The German peasants

1 Matthew Arnold's story; see p. 314.

2 “'Philadelphia American," December 8, 1888. 
in 1525 fought for every principle that it was the fortune of England to realize much later. The English-Americans may go. The republic will last." 1 Men among us whose words have some weight speak thus lightly of a decay of Anglo-Saxon strength in America. Meantime, the flood ever rises: through the sluices pour currents from a score of peoples, the stream often noisome through ignorance and vice. No fact is better established than that strains of men, as of the lower animals, are improved by crossing. To breed in and in produces degeneration. New blood, provided it comes from sources not too remote, and is without morbid taint, invigorates. New blood is to be welcomed, and yet it should not be infused to so large an extent as to make of the strain a different thing. Anglo-Saxon we ought to remain, if Anglo-Saxon freedom is to be maintained. "It is part of the inexorable logic of fact and nature, that you cannot have the growth of the living creature, plant, animal, man, nation, serionsly injured in the growing time and then set right in subsequent years. The stunted tree, the starved child, the crushed and spirit-broken nation, bear the marks of their injury to the encl." ${ }_{2}$ As regards political freelom, every people but the Anglo-Saxons has been at some time erusherl and become spirit-broken. 'T' Anglo-Saxons alone can our American freedom be safely intrusted. Invigorate the stoek as you please with blood from Seandinavian, German, Irish, French, Russian, from whatever good source, - but let it remain Anglo-

1 I'rivate letter to the author, from a "foreign-lorn Inited States citizen."

2 Peter Bayne: Chief Actors of the Puritan levolution, p]. 71, 72. 
Saxon still. "Our American Republic will endure just as long as the traditions of the men of English descent who founded it are dominant there," and no longer.

It is not probable that the difficulties which beset civilized men at the present day are extraordinarily Embarrass. serious; indeed, it is quite certain that our ments not ex-
traordinarily troubles are small as compared with those serious. with which, in the past, civilization has repeatedly been threatened. They are, however, sufficiently serious, and among civilized men to-day the English-speaking race has its full share of embarrassments. In a cursory way, some of these embarrassments have been indicated: it is no part of the purpose of this book to show how they must be met. The problems of the time are abundantly discussed. Let us only discuss here the matter whether our race, so numerous, so strong, so resourceful, is also in other respects so circumstanced as to be likely to wage a winning war. Let us ask two questions: 1. Does the English-speaking race respect and love the freedom which it has inherited? 2. Has the race within itself any proper feeling of brotherhood? Do its members stand ready to join hands, believing that in union there is strength? Only if these questions can be answered in the affirmative can Anglo-Saxon freedom be certain of permanence. 


\section{CHAPTER XIX.}

\section{DO WE RESPECT OUR FREEDOM?}

First. Do we respeet the freedom which we have inherited?

On the 30 th of April, 1889, the writer, in a great city lying in the border-land between North and South, watched the passing of a vast procession. Thus the people had chosen, upon the cen- $\begin{gathered}\text { tion of } A \text { pril } \\ 30,1889\end{gathered}$ tenary of the inauguration of Washington and of the going into operation of the Federal Constitution, to do honor to our ehief hero, and to the ordered Anglo-Saxon freedom which he fought to sustain. It was a eity which at the time of the celebration was, and for many years before had been, a house divided against itself. Sharp race-conflicts between black and white, bitter religions feuds, discord between capitalist and laborer, between the drinker and prohibitionist, between Northerner and Southerner, - quarrels of many kinds proceeding sometimes beyond recrimination to bloodshed, - laad for years found in that city an arena. On that day, however, was presented a rematrable spectacle of harmony. Over each division of the marehing columm, everywhere from house-tops and windows, waved the stars and stripes. A division of schoolhoys followed a division of gray-beards. Catholic and Protestant stepped for once to the same musie; so, too, the Knights of St. Patrick and the Soeiety of St. George; 
the negro and the master whose authority the Civil War had broken; Bohemians and Hungarians with a noisome flavor of anarchy in their somewhat sullen lines, and the solid representatives of the mart and of the bank; Confederate veterans and the Grand Army of the Republic. For the moment all was harmony; disputes were hushed; the "plain people" was at one as regarded paying honor to the great instrument upon which our polity rests, and the great soldier and magistrate who was its main establisher and upholder, - at one in respect for our AngloSaxon freedom.

There can be no doubt that in England, too, the "plain people," however much reluctance the priviThe people's leged class might show, would be equally love of Anglo- harmonious, if similar occasion were given ;
Saxon freedom.

nor can there be any doubt as regards the universal zeal for democratic freedom of each great English dependency. ${ }^{1}$ Nor is it the "plain people" alone who stand strongly for democracy. However it may be here and there eyed askance, and its inevitable progress toward supreme power regarded as a calamity, it is not the sentiment of the scholars and thinkers best worth following. Andrew CarView of An- negie, a generous representative of capital, drew Carne- glorifies "Triumphant Democracy"; but
gie. there are voices better worth heeding than that of the fluent, quick-minded Scotch iron-master, that have spoken strongly, in well-weighed words, their faith. Says J. Toulmin Smith, ${ }^{2}$ treating of the kind

1 See Dilke on this point, Problems of Greater Britain, p. 490.

2 Local Self-Government and Centralization. London, J. Chapman, 1851, p. 40. 
of sense most useful in state affairs, with a confidence which many will think excessive :-

"It is well worthy of remark that it is not the mass of the folk and people who are insensible to sound argument and reason. This is a of J. Toulcharge often made by those who imagine min Smith. themselves superior to their neighbors. The truth is, however, that the most really ignorant classes, and the most ineapable of comprehending sound argument and reason, are often found to be those who are commonly called the educated classes. The cause of this is very simple. What is now called 'education,' and what many are anxious to enforce by a national system, is nothing but putting a certain artificial mould upon the mind, which, instead of developing its powers, does but serve to wrap it in prejudices and bind it to conventionalisms. The artisan classes, at least equally called upon by external circumstances to exereise the native powers of mind, have fewer prejudices to bloek the way to the sober entertainment of argument and reason. . . .

"For Anglo-Saxon freedom, we must have, indeed, educated men, but it is not reading and writing, science and arts, that ever did or ever can make the educated man. lingrossing the attention with these may indeed be made the most effective means of preventing the man from becoming truly educated. of this, l'russia offors a striking example: with a nominal education, a state erlucation of great elahorateness, the result is, as it was intended to be, a people incinable of dealing with their own wants and conditions, and submitting to be dealt with as herds of animals, who exist only for the behoof of kings. An olserv- 
ant and thoughtful writer, speaking of the Prussian system, so ignorantly held up as a system to be adopted in this country, well describes that people, as being the most superintended, the most interfered with, the most destitute of civil freedom and political rights, - in a word, the most enslaved people in Western Europe; and the most educated, that is in what is conventionally called education, - the drilling of the mind, not its development. This testimony is confirmed by all who thoroughly, and not merely superficially, have understood and watched the system, and who have not been deluded by meaningless statistics of schools." 1

Shall we accept this without qualification? Forty years have passed since the words just quoted were written. Much history has been made by Prussia in the intervening time. Under able leaders she has shown herself marvellously powerful. As regards the people, however, what the world has had occasion to notice particularly is the docility with which they have suffered themselves to be led. The initiative has been from the ruling dynasty and its great servants. The Court has supplied the plan of action, the brains and the energy for carrying it out, using the resources and mighty strength of an unresisting people to secure objects undoubtedly adapted to promote the well-being of the people (who can doubt the blessing coming to the Germans from a united Germany?); nevertheless, objects whose value the people did not at all appreciate till they were gained, and which they were quite incompetent to secure if they had appreciated them. It has been said that

1 Local Self-Government and Centralization, p. 321. 
the Germans of to-day are cheated by a mere eounterfeit of representative institutions, while real freedom is far away from them. To some extent the remark is true. Though the German Parliament debates and rotes, the power of the dynasty is very great, and not diminishing. Docility is still the most marked characteristic of the German nation, as it was in the time some decades since, when Matthew Arnold spoke of their "Corporalism," their obsequiousness before those in authority, a trait resembling the obsequiousness of the subaltern before his superior officer, a quality which Mattlew Arnold found marked in a man even so supreme as Goethe. Nowhere at the same time is "education" so elaborate and so allembracing. Not a youth or maiden can escape the inevitable drill. That in a thousand ways the drill is valuable, who will doubt? There is, however, a discipline gained at the bench, the forge, and the counter, - in the wrestle of affairs, - more than all a discipline gained in the perfectly unfettered diseussion and action of a free people. As a pualification for eitizenship in a really free land, it cammot be doubted that the discipline of business and political activity is superior to that of the schools, - that the plain carpenter, blacksmith, and shopkeeper, with wits keen from their breall-wimning, and also from the argument at the comer, in the store, - alass: also in the saloon, - ean judge about a multitule of public questions as well as, or better than, the man trained in books only.

This point is so interesting. it is well wortle while to dwell upon it more at longth. As regateds the progress of feredolom, the histery of Bryce. 
of men well placed and highly cultivated is often a discreditable one. Bryce notes the apparent paradox, that where the humbler classes have differed from the higher, they have often been proved by the event to have been right, and their so-called betters wrong. Many European countries have illustrated this during the last fifty years. A respectable minority of the educated English, to be sure, sympathized with the national movement in Italy, but far more workingmen. In the American Civil War, the working classes stood for the North; a-majority of the so-called educated for the South. In America, abolition had more friends among the less educated than among the best educated. The historical and scientific data, continues the critic, on which the solution of a difficult problem depends, are as little known to the wealthy as to the poor. Ordinary education, even of a university, does not fit a man to deal with these questions, and sometimes fills him with a vain conceit of his own competence which closes his mind to argument and evidence. Nearly all great political and social causes have first made their way among the middle and humbler classes. The initiative proceeds from certain individuals, lofty and piercing minds; these are followed by the masses, while the higher classes frown and persecute. Of this course of things, Christianity is the most striking instance. ${ }^{1}$

Elsewhere ${ }^{2}$ Bryce makes reference to the description of Plato, in which "the mules and asses of democracy are made to prance along the roads, scarcely deigning to bear their burdens. The passion for unrestrained license, for novelty, for variety, is

1 American Commonwealth, II, p. 213, etc.

2 Ibid., p. 614. 
to him the note of demoeracy." This view Bryce compares with that of such modern eritics of democracy as Sir Henry Maine, who apprehend that monotony and even obstinate conservatism are the faults to which democraey is liable. Each theory, he sums up, is plausible in the abstract, and each equally wide of the faets; for demoeraey under proper conditions is quite able to follow the reasonable mean.

Said Gladstone at Oxford in 1878: "I traee in the edueation of Oxford of my own time one great defeet. Perhaps it is my own fault; but I must admit that I never learned at Oxford that which I have learned since; namely, to set a due value on the inestimable prineiple of human liberty. The temper which too mueh prevailed in learned and academical ranks was to regard with jealousy and fear the prineiples of liberty." 1

And another able Englishman, Leeky, deelares ${ }^{2}$ that the influence of the English universities, representing expeeially, of course, the cultivated, has leecn almost uniformly hostile to politOf Lecky. ical progress. (J)inions formen in drawingroom and

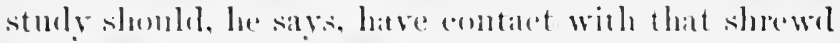

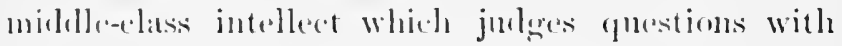
broales sympathes often, and on highore issures. In politics the evils springing from monopuly are sometimes grrater than these springing from incompe-

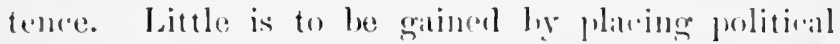
power exclusively in the hands of a small lestrieterl elass, even where it is the most enlightened elass.

"guoted in Isnden "Spectalor," Jamuary I, tsin), article " ciladstone's lirthlay."

"History of the Eightecuth Century, 111, 1. 233, ete. 
Class bias often does more to distort than education to expand the intellect. Rectitude is by no means always proportioned to intellectual development. A small wealthy class will be much less quickly and seriously injured by misgovernment than the great industrial community; it may, indeed, be benefited by a policy which is very injurious to the country at large. In the eighteenth century in Englaud, a small class had a monopoly of power, meanwhile shamefully neglecting the education, sanitary condition, and general well-being of the masses of the nation, who sank far toward utter ignorance and lawlessness. The following quotation from Addison's "Remarks on Italy," introduced by Lecky, in the course of his discussion, has much interest:-

"One may generally observe that the body of a people has juster views for the public good, and purof Addison. sues them with greater uprightness, than the nobility and gentry, who have so many private expectations and particular interests which hang like a false bias upon their judgments, and may possibly dispose them to sacrifice the good of their country to the advancement of their own fortunes; whereas the gross of the people can have no other prospect in changes and revolutions than of public blessings, that are to diffuse themselves through the whole state in general."

If Englishmen belonging to the highly favored and cultivated class can give such good reasons for popular government, it is to be expected certainly that Americans of corresponding position should furnish examples of writers maintaining emphatically the same view. No doubt there are among cultivated 
and well-to-do Americans many, fastidious until they become finical, who shrink from the turmoil of a democracy, and would willingly, if they could, limit political power to those having "a stake in the country," or standing on a high level of education. Among the best and wisest, however, there is no dislike of the plain people, and no desire that power should be anywhere else than in their hands. No American has come nearer to being born and bred in the purple than John Lothrop Motley; and his life, after reaching manhood, was largely passed at courts, - St. Petersburg, Vienna, Berlin, Dresden, the Hague, and London, - in which he was always a prime favorite of prinees and nobles, and beheld always the most favorable side of the systems whieh they sustained. Yet Abralıam Lincoln limself was not more sturdily democratie than Motley.

He writes: "I don't think there is any danger of my losing my American feelings, and my republican tastes... I I have a sincere belief that a Brobdignag people like ours is the most gignutit phenomenon that traveller or philosopher has ever seen or intaginerl, and that it is beraluse the giant is so big and so near and grows so fast, and fecels his ligness so much more and more every diyy, that one sees the superticial defects of his eomplexion and the wats on his nose... I I am most sincere when I say that I should never wish Amerio to be Anglicized in the aristocratio sense. . . I foel too keconly what it fearful price is paisl by the linglish people in order that this splendid aristocratey, with their parks and

1 To his wife, Letters, 1I, p. 294. 
castles and shootings and fishings and fox-huntings, their stately and unlimited hospitality, their lettered ease and learned leisure, may grow fat, ever to be in danger of finding my judgment corrupted by it."

Again he writes: ${ }^{1}-$

"For one, I like democracy. I don't say that it is pretty or genteel or jolly; but it has a reason for existing, and is a fact in America, and is founded on the inimitable principle of reason and justice. Aristocracy certainly presents more brilliant social phenomena, more luxurious social enjoyments. Such a system is very cheerful for a few thousand select specimens out of the few hundred millions of the human race. It has been my lot and yours to see how much splendor, how much intellectual and physical refinement, how much enjoyment of the highest character has been created by the English aristocracy; but what a price is paid for it! Think of a human being working all day long, from six in the morning to seven at night, for fifteen or twenty kreutzers a day, in Moravia or Bohemia, Ireland or Yorkshire, for forty or fifty years, to die in the workhouse at last. This is the lot of the great majority all over Europe; and yet they are of the same flesh and blood, the natural equals in every way of the Howards and Stanleys, Esterhazys and Lichtensteins."

More detailed and emphatic than the testimony of the great historians just quoted is that of President Eliot, of Harvard College, ${ }^{2}$ also a Boston Brahmin

1 To his eldest daughter, November 23, 1864, Letters, II, pp. 192, 193.

2 "The Working of the American Democracy." Phi Beta Kappa oration at Cambridge, June 28, 1888. 
of the highest caste (aceording to Dr. Holmes' well-known ranking), the heir of the careful culture of many ful euture of many generations, himself Fliot, of carefully trained and refined, and through position and ability among the chief of American educators. Dismissing the experience which Europe has had of democraey as entitled to little weight, when we are forming judgments, he declares that satisfactory evidenee coneerning the practical working of democratic institutions ean be gained only from the United States. Only there, has "a well-rooted democracy on a great scale ever existed."

"The first question I wish to deal with is a fundamental one: How wisely, and by what process, has the American people made up its mind npon public questions of supreme difficulty and importance? Not how will it, or how might it, make up its mind ; but how has it made up its mind? It is commonly sairl that the multitude, being ignorant and untrainerl, eannot reach so wise a conclusion upon questions of state as the cultivated few; that the wisiom of a mass of men can only be an average wisclom at the best; and that democracy, which in things material levels up, in things intellectual and moral, levels down. Even De Tocqueville says that there is a middling standard of knowledge in a democrney, to which some rise and others descend. Leet us put these speculative opinions, which have so plausible a sound, in contrast with American facts.

"The people of this comntry have haid three supreme questions to settle within the list hunded and thirty years: first, the question of independence of Great Britain ; secondly, the question of forming a 
firm federal union; and thirdly, the question of maintaining that union at whatever cost of blood and treasure. In the decision of these questions, four generations of men took active part. The first two questions were settled by a population mainly English; but when the third was decided, the foreign admixture was already considerable. That graver or more far-reaching political problems could be presented to any people, it is impossible to imagine. Everybody can now see that in each case the only wise decision was arrived at by the multitude, in spite of difficulties and dangers which many contemporary statesmen and publicists of our own and other lands thought insuperable. It is quite the fashion to laud to the skies the second of these three great achievements of the American democracy; but the creation of the Federal Union, regarded as a wise determination of a multitude of voters, was certainly not more remarkable than the other two. No government, - tyranny or oligarchy, despotic or constitutional, - could possibly have made wiser decisions or executed them more resolutely, as the event has proved in each of the three cases mentioned.

"In all three of the great popular decisions under consideration, most remarkable discernment, patience, and resolution were, as a fact, displayed. If these were the average qualities of the many, then the average mental and moral powers of the multitude suffice for the greatest deeds; if they were the qualities of the superior few infused into the many by speech and press, by exhortation, example, and leadership, even then the assertion that the operative opinions of the unlearned mass on questions of state 
must necessarily be foolish, their honesty only an ordinary honesty, and their sentiments vulgar, falls to the ground. The multitude, it would seem, either can distil essential wisdom from a seething mass of heterogeneous evidence and opinion; or can be inspired, like a single individual, from without and above itself. If the practical wisdom of the multitude inaction be attributed to the management or to the influence of a sagacious few, the wise result proves that these leaders were well chosen by some process of natural selection, instead of being designated, as in an oligarchy, by the inheritance of artificial privileges. . .

"There is a limited sense in which it is true that in the United States the average man predominates ; but the political ideas which have predominated in the United States, and therefore in the mind and will of the average man, - equality before the law, national independence, federation, and indissoluble union, are ideas not of average, but of superlative merit. It is also true that the eommon school and the newspaper echo received opinion, and harp on moral commonplaces. But unfortmately there are many accepted humane opinions and ethieal commonplaces which have never yet heen emborled in national legislation, - mueh less in international law, - and which may therefore still be repeated to some arlyantage. If that comprelousive commomplace, "Ye are all members one of another,' comld be ratizod in international relations, there would be an end of war and industrial isolation."

Presiclent Eliot enumerates fom forms of mental and moral activity of the highest usefuluess: tirst, 
that which maintains political vitality throughout the Federal Union; second, that which supports unsubsidized religious institutions; third, that which develops the higher instruction in the arts and sciences and trains men for all the professions; and, fourth, that which is applied to the service of corporations. All these forms of activity mark the American democracy. No disposition appears in the masses to oppress those better placed. "After observing the facts of a full century, one may say of the American democracy that it has contracted public debt with moderation, paid it with unexampled promptness, acquired as good a public credit as the world has ever known, made private property secure, and shown no tendency to attack riches, or to subsidize property, or in either direction to violate the fundamental principle of democracy, that all men are equal before the law. The significance of these facts is prodigious. They mean that as regards private property and its security, a government by the many and for the many is more to be trusted than any other form of government; and that as regards public indebtedness, an experienced democracy is more likely to exhibit just sentiments and practical good judgment than an oligarchy or a tyranny."

As to progress and reformation, continues President Eliot, combating here ideas expressed in Sir Henry Maine's “ Popular Government," nowhere else is religious toleration so thoroughly put in practice as in the United States; nowhere else has there been such well-meant and persistent effort to improve the legal status of women, in behalf of hospitals, asylums, reformatories, and prisons, to apply legislative 
remedies to acknowledged abuses and evils. For promptness in making physical forces and machinery do the work of men, the people of the United States incontestably surpass other peoples. The notion that democracy will hinder religious, political, and social reformation and progress, or restrain commercial and industrial improvement, is a chimera. Lastly, says President Eliot, no other land has succeeded so well in producing the gentleman, and that consummate fruit of society at its best, - the lady. "Since democracy has every advantage for producing in due season and proportion the best human types, it is reasonable to expect that science and literature, music and art, and all the finer graces of society will develop and thrive in America, as soon as the more urgent tasks of subduing a wilderness and organizing soeiety upon a new and untried plan are fairly accomplished." 1

Among English-speaking men, then, is there satisfaction with the freedom which they have inherited? At one end of the social scale there is no doubt an element which would, if it could, turn liberty into license, order into anarchy: it is, however, newly arrived,

General resipect and love for Anglosaxonfreedom among high and low.

1 In the "Century" magazine for August, 18: $)$, Prosilent Filiot furnishes, in an article called ". The forgotten Millons," an interesting supplement to his bli lieta kajpra address. To peoplo indium to ly" hyterical over the woes and sins of the present, an age which, whatever may be sail agisinst it, is the best age which the world has ever seen, this acenut of the simple, lomorable life of a plain Xew kngland town will afford profituble reading. For, as Mr. Eliot says: " I'his sequestered, wholesome, and contented community affords at fair type of the organization of basal American sonety. Dhe allowance marle for difference of climate, snil, diet, and local nsage, this is very morly the way in which from thirty to forty millions of the Anerican penplo live." 
unassimilated, and we may confidently look forward to its absorption into the strong and sound AngloSaxon environment. Again, among the well-placed, as regards means, position, and high education, both in England and America, are undoubtedly some who dread democracy, and who would, if they could, strengthen the hold upon the world of narrowing institutions which we are fast forsaking. The great public heart, however, whether we study its pulses among the masses or among those who by ability, culture, and place, are the leaders of the world, clings with love to our forms, upholds them with enthusiasm, and anticipates their full triumph with the highest lope. 


\section{CHAP'TER XX.}

\section{A FRATERNITY OF ENGLISII-SPEAKING MEN.}

Finalis, the question is to be answered whether in the Anglo-Saxon world there is any disposition toward proper brotherhood. Among the The idea of English-speaking races, thoughtful minds an Anglonow and then express the idea that a erhood. closer coming together of the various Anglo-Saxon bodies, isolated and seattered about the world, is at thing to be desired. In the British empire, in which it has come to pass that the great dependencies are connected with the mother-land by links searcely appreciable, Inperial Federation has grown to be a popular notion. The dream is entertained that all may become England, - that the distinetion between mother-land and dependeney $\begin{aligned} & \text { View of J. R. } \\ & \text { seeley. }\end{aligned}$ having been quite done away, a great world-Veniee may come into existenee, throngh which indeed the seas shall flow, - to unite, however, not to divide: because the seas are to be the easy highways through which fellow-citizens may speedily move in their intercourse with one another. $A$ still broader incorporation into a compact whole than even this has been thought of, and the idea expressed by men whom, in their respective communities, all revere. 
John Bright wrote in 1887 to the Committee for the Celebration of the Centennial of the American Of John

Constitution: "As you advance in the Bright. second century of your national life, may we not ask that our two nations may become one people?" Sir Henry Parkes, one of the foremost of Sir Henry statesmen of Australia, addressing the Parkes,
ier of NemSouth Wales. 25, 1887, said still more definitely: "I firmly believe it is within the range of human probability that the great groups of free communities connected with England, will, in separate federations, be united to the mother-country; ... and I also believe that in all reasonable probability, by some less distinct bond, even the United States of America will be connected with this great English-speaking congeries of free governments. I believe the circumstances of the world will develop some such new complex nationality as this, in which each of the parts will be free and independent while united in one grand whole, which will civilize the globe." Mr. Goldwin of Goldwin Smith, ', though believing a political union Smitb.

in the highest degree unlikely, says: "I prize and cherish as of inestimable value to us, all the moral union of the Anglo-Saxon race. I do not see why there should not, in the course of time, be an Anglo-Saxon franchise, including the United States."

Sir George Grey, at different times governor of an Australian colony, of New Zealand, and of South of Sir George Africa, one of the most illustrious of the Grey. men who have developed for England her 1 “'Macmillan's jíagazine," August, 1888. 
great possessions in the South Pacifie, eontemplates an eventual, though perhaps far-off league, between members of the English-speaking race, ${ }^{1}$ in which the United States will be not only included, but, displacing England, will become the leader.

Mr. J. C. Firth, a eitizen of New Zealand, who has travelled in America, sees "promise of a coming brotherhood, which, if wisely fostered, will inevitably bind together the English-speak-

Of J. C. FIrth. ing race all over the world for mutual help, for mutual blessing.... Not until, in the near or distant future, the Amerieans take a eommanding position in the coming eonfederation of the Englishspeaking race, can they elaim to wear the proud motto, 'per mare per terram.' Not till then will they hold their proper place by sea and land. . . . What are all difficulties before the miglity force existing in common laws, common literature, religion, love of freedom, common lome life, - above all, a common language: It needs but a conviction and establishment of a commmity of interest to enable the mighty forces I have deseribed, to work out in some coming time the confederation of the Engrishspeaking rave all over the world. . . Should such a eonfederation ever be established, and I venture th think the possession of a common langhage will ultimately secure it. one of the greatest sifeguards for the peare of the workl, for the welfare of our common humanity, will have berell obtatinet."."

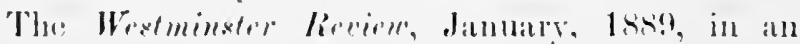
article entitled ". Folderation r.s. Witr;" "xpresses itself as follows: "It has been computed that, in-

1 Froude: Oceana, p. 312.

2 Our Kin across the Sua, 1355. 
cluding the population of the United States of America, some hundred and five millions of people Of the West. speak the English language, and belong minster Re- generally to the Anglo-Saxon race. Now,
view. supposing that England and the colonies united in forming an Imperial Parliament, to which delegates might be sent from each of our dependencies; and suppose the Parliament had for its function the consideration of imperial interests, leaving colonial matters to local legislation, it is manifest that the bond of union between the mother-country and her dependencies would be drawn much closer than at present, and greatly to the advantage of all. In this assembly, Canada, Australia, the South African Colonies, New Zealand, and the West Indian Islands would be represented, questions of general utility would be freely ventilated and fairly discussed, reciprocal trade regulations would be established on a satisfactory basis, and projects for mutual defence in case of war would be arranged. At present, the British empire possesses the most extensive territory and the largest population, together with the greatest amount of wealth and commerce, owned by any nation in ancient or modern times. We moupolize one-third of the world's trade; more than one-fifth of the world's population is ruled over by the Queen of England; our flag waves over oneeighth of the habitable globe. In time, and possibly not a very long time hence, the people of the United States, numbering at present more than sixty millions, may form a part of an Anglo-Saxon Confederation, which would then be, unquestionably, the strongest in the world, and which would unite 
the great Anglo-Saxon family by the strongest ties of any, - those of self-interest. Thus, were the union we have alluded to formed by England, her colonies, her Asiatic dependencies, and the United States of America, the important fact would be established that about one-fourth of the human race would have agreed to settle their disputes by arbitration instead of by the inhuman and costly process of war. 'The question now arises, How would the other powers of Europe profit by this example? When we consider that the weaker nations have everything to lose and nothing to gain by war, yet that they are obliged to retain, at the cost of heavy taxation, eonsiderable military forces to resist possible aggression, it is natural to suppose that they would be likely to join in a confederation which, to the extent of their relations with it, would assure them of immunity from disturbance; and therefore we may suppose that one by one the weaker nations will join the great Anglo-Saxon Union. It would then remain for four or tive of the principal governments of Europe to (onsider whether they would keep up enormous armies at ruinous taxations, with the result of augmenting public debt and increasing the discontent of their subjects, or whether they would agree to a system which would enable them to dishand their armies, lessen taxation, reduce debt, and banish discontent. It would eertainly be a question for autocrats to consider, but not for the'm only. The subjects of the great powers would also express their opinion, and there is little dould as to the form that opinion would take: for, juclging by the present strong tendency of European thought, 
the question will in some way solve itself at no distant period."

Such a citation of opinions, though long, cannot be uninteresting. It will be noted that the voices from the British dependencies are especially strong in favor of an English-speaking bond, and especially of the New cordial toward America. A conviction is Zealand Her. ald. growing, says the New Zealand Herald, of Auckland, "that one great destiny awaits all the branches of the English-speaking race, and that in working out that destiny the Americans and the colonists will take a by no means secondary part. The brotherhood which will ultimately lead to the recognition of this unity of mission is now undergoing a steady development."

The idea of some reconstitution of the family bond has found expression more often from citizens of Indiffereuce the British empire than from Americans, of Americans. though men are not wanting in America, in whose minds has arisen the conception of a doing away with the Anglo-Saxon schism as a thing possible and to be wished for. The prevailing mood among us, however, is that of self-sufficiency. Absorbed with problems and interests that seem nearer, we let the broad thought go.

If, however, the reader has followed with any sympathy and attention the story told in this book, he

Reasons in favor of eulti. rating frater. nal feelings among Eng. lish-speaking lands. will be prepared to see that if we form a link anywhere, our proper affiliation is with England, and her chiidren scattered east and west. There are, indeed, to-day,

1 For further evidence of the cordial fecling of Australia for America, see "Troblems of Greater Britain," p. 6is. Sec alio an article by R. H. Bakewell, of New Zealand, "The Loyalty of the Colonies," in the "Ninetecnth Century." for August, 1890 . 
as there were in the time of the American Revolution, two Englands and two Americas. Of one England, Lord Dundreary is the type; as of one America, the appropriate type is the tuft-hunting daughter of the plutoerat, who will sell soul and body to get Lord Dundreary for a husband. There is besides, the stalwart, manful England for which stand Gladstone, John Bright, and James Bryce; as there are in America the excellent "plain people," whom Abraham Lineoln loved and trusted. While Miss Moth flies at her aristocratic luminary, careless of the singeing she may receive, why should not the nobler England and the nobler Ameriea elasp hands? The English admit and have repented humbly of the folly and injustice by which we were driven to leave them. Says Thackeray: " "The foolish exactions, English readpetty ignominies, and the habitual inso- iners toadmit lence of Englishmen toward all foreigners, past mistakes. all colonists, all folk who dare to think their rivers as good as English rivers; the natural spirit of men outraged by our injurious domineering spirit, set Britain and our Ameriean eolonies to quarrel; and the astonishing blunders of the system adopted in England, brought the quarrel to an issue which I, for one, am not going to deplore. In less than seven years after Wolfe's vietory, the ignorant tyrmny of England over her Anerican colonies provoked the great struggle which terminated fifteen years later in the Declaration of Independence." Such acknowledgments of mistakes are most frecely made; the disposition is most earnest to make the mistakes grool. The sound English heart goes ont to those who, in

IIn "The Virginians." 
Gladstone's words are "our kin beyond the sea." Wrote a poet at a time when the two nations seemed drifting toward war:-

"Men say, Columbia, we shall hear thy guns : But in what tongue shall be thy battle-cry? Not that our sires did love in days gone by, When all the Pilgrim sires were little sons In merry homes of England! Back and see Thy satchelled ancestor! Behold, he runs To mine, and, clasped, they tread the equal lea To the same village-school, where side by side They spell 'Our Father'! Hard by, the twin pride Of that gray hall whose ancient oriel gleams Through yon baronial pines, with looks of light, Our sister-mothers sit beneath one tree.

Nor force, nor fraud shall hinder us! Oh, ye Who, north or south, on east or western land, Native to noble sounds, say truth for truth, Freedom for freedom, love for love, and God For God, - oh, ye who in eternal youth Speak with a living and creative flood The universal English, and do stand Its breathing book, - live worthy of that grand Heroic utterance! - parted, yet a whole, Far, yet unsevered, - children brave and free Of the great mother-tongue: and ye shall be Lords of an empire wide as Shakspere's soul, Sublime as Milton's immemorial theme, And rich as Chaucer's speech and fair as Shakspere's dream!" 1

The notion of an Anglo-Saxon brotherhood ought to have some interest for Americans. The sugges-

Sir Edwln Arnold's plan for an interuatlonal council. tion of Sir Edwin Arnold, made to President Harrison, was that there should be an international council to arbitrate all 
matters in dispute, from whose decisions there should be no appeal. Such a scheme would be in itself a loose kind of federation; and as far as a formal bond is concerned, without doubt it would be all that is expedient. As to a union, only one purely moral is possible or desirable. For some sueh clasping of hands, the world is certainly ripe. Through steam and electricity, time and space are annihilated. The seas no longer divide, but unite. Should the will for such fraternity be felt, there is no power of nature or man which could interfere to prevent. Had we but the will! We nurse too carefully old prejudices; we remember too long aneient injuries. We train our ehilılen, as we were trained ourselves, to execrate all things British, to think only of England's tyramny. Do we not know that more than lailf of England were, in the Revolution, really on our side, regarding our canse as their own, - and that the deseendants of the great masses who felt with us. prityed for us, and rejoiced in our suecess, now lobld England in their own hands" 1

We have been so over-hospitable in receiving all eomers that we alre in some linger of losing our eharater as an Anglo-saxm lambl. The Thirteen colonies were a fairly homogeneous body, with Coltic and Teutonic adnixtures too small to afferet apprectialsy the miss alunt them. With indepremilenee.

Necessity of doing nowiethlng to pre. vent Inclo. Saxon tracli. tione from becoming obncurind.

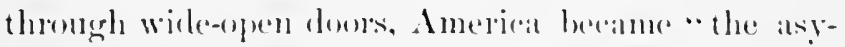
lum for the olpmessed of all nattons." With what result? 'Twenty-fom million of anr pepulation are 
descended from immigrants since 1790 , while twentyeight million are from the founders of the land. One in every six among us is of foreign birth, while one in every three has both parents of foreign birth. To such an extent are we overswept, stumned on the one hand by the Irish cry, weighted in another direction by inert millions just released from slavery, threatened in still another by an Asiatic flood, penetrated through and through with a Teutonic and Scandinavian inundation which, welcome though it is and closely allied though it is, cannot undertake our free life without a process of assimilation, — to such an extent is America overswept that it is natural for thoughtful men of the original stock to feel somewhat insecure, and to ask whether it may not some day be desirable and feasible to brace themselves against a flood which may possibly carry us quite away from our ancient moorings. Our system of public education, never too efficient, is in some quarters threatened with extinction. There are millions among us into whose minds our great traditions have never entered, or have entered only to be mocked at; while in the case of those of us who are of Anglo-Saxon blood, these traditions tend to become obscured and weakened. Precisely here may be found an important reason for a brotherly drawing toward those who, in spite of superficial differences, are yet substantially one with ourselves. As in a battle-line the electric touch of a comrade's elbow, when a rank dresses up before a row of hostile, levelled rifles, has often given new heart to a dispirited, failing soldier, reviving as by an electric current esprit de corps, patriotism, the fading recollection of a great cause 
for whieh arms have been assumed; so the toneh of the great comrade Anglo-Saxon peoples will bring to vivid eonseiousness in all the thought of the important things held in common, and a new appreciation of their value.

Every Anglo-Saxon should hold the leadership of his race to be something with which is bound up the welfare of the world. "It is not the result of aeeident merely, or of good fortune, $\begin{aligned} & \text { Benefits to } \\ & \text { the world } \\ & \text { from Anglo. }\end{aligned}$ manifestly, that the English raee has been $\begin{gathered}\text { fromonon } \\ \text { sanglo. } \\ \text { ship. }\end{gathered}$ the only race outside of quiet, eloistered Switzerland, - the only raee standing forward amidst fieree contests of national rivalries, - that has sueceeded in establishing and maintaining the most liberal forms of government. It is, on the eontrary, a perfectly natural outcome of organie development. The English alone have approaehed popular institutions through habit. All other raees have rushed prematurely into them through mere impatienee with halit, - have adopted democraey instead of cultivating it." 1

The French have possessed politieal freedom only since their Revolution; at the present moment, after a century of instability, living under a constitution strange to them, derived from that of Anglo-Saxon states, and which may fall to pieces at any lontr. The Germans have possessed no proper political frechom since the clays of the migration of the nations. and are so involvert in perils from neighbors east and west that they dare not give up for it the gevernment of a strong autociat. Russia presents a pirture of respotism from whirh it is seareply possible to hope

1 Woodrow Wilson in "Polit. Sci. Quar.," March, 1589, p. 169. 
that her people can ever be freed. How plain that the hopes of a well-ordered liberty in the world are bound up with the English-speaking race! Whatever enthusiasm for it individuals or classes may show, among Frenchmen, Germans, or Russians, the historic discipline of those stocks has not been such as to prepare them to maintain it. These nations have all, at one time or another, been crushed and spirit-broken. The Anglo-Saxon, on the other hand, has preserved for two thousand years the connected tradition of ordered constitutional freedom. It is flesh of his flesh and bone of his bone. The strength of the stock - perhaps it would be more just to say the peculiar circumstances of its position - have caused that it alone, among the great races of the modern world, has preserved the primeval liberty which at the outset was the possession of them all. That liberty is for human welfare the most precious of possessions, is a proposition which surely need not be argued. Scarcely less obvious is the proposition that the maintenance of ordered liberty in the world is bound up with the leadership of the Anglo-Saxon. Is this leadership in any way imperilled?

It is no doubt a far-away danger which threatens Anglo-Saxondom from any foreign power whatever, Possible perils but it is not foolish to take thought for from China. what may possibly sometime come about. Suppose the four hundred million of China should come forth to battle for dominion. The Chinese have of late grown enterprising and shown a disposition to forsake their home. They thrust themselves uncomfortably upon Americans, and still more uncomfortably upon the Anglo-Saxon nearer to them, in 
the South Pacific. Says Sir Henry Parkes: "The Chinese are a superior set of people, belonging to a nation of an old and deep-rooted civilization.... It is because I believe the Chinese to be a powerful race, capable of taking a great hold upon the country, and because I wish to preserve the type of my own nation in these fair countries, that I am and always have been opposed to the influx of Chinese."1 Unquestionably the Chinese have been badly treated. English and Americans deserve to suffer, but for the sake of civilization, the suffering ought not to go too far. As we plainly see, at last, the Chinese are quite capable of showing resentment; and we can be certain that with their vast numbers and in many ways advanced civilization, they are quite eapable of becoming formidable opponents. Mr. Firth, of New Zealand, says: "The Chinese difficulty is a direct consequence of the folly or avarice of our rulers, both in the British empire and the United States. ... In the interests of English and American commeree, the Chinese emperor was compelled, by the logic of canon law, to ardmit foreigners to reside and trade in eertain (hinese ports, similar treaty rights being granted to Chinese people to reside, trade, and work in the United States and in the British dominions." Mr. Firth goes on to say: "No one had any idea that the Chinese, eonservative and exelusive as they have always been, wonld ever avail themselves of this right. How great was the mistake: A vast emigration at ance set in to Australia and California, mutil there has been danger that large portions of the Enited States and Anstralia might

1 Dilke: Problems of (ireat Britain, p. 529. 
be overrun. In the Sandwich Islands, where the Chinese outnumber the Europeans and Americans, their bearing has become changed; they are no longer inoffensive and obedient. There is a possibility that the characteristics of Chinatown, in San Francisco, may appear on a scale vastly enlarged in a hundred cities, - that Anglo-Saxon lands, indeed, may become little better than Chinese colonies." So writes this spokesman of the English-speaking world of the South Pacific, and advises that England and America limit the annual immigration of Chinese into the United States and Australia to the numbers of English and Americans entering China as residents, - a course which would settle the present difficulty without abrogating the treaty. ${ }^{1}$

But suppose that China, following her new inspirations, should refuse to be limited? It is conceivable that the bland Asiatic, sensible at last of his injuries, may try to punish, perhaps to overwhelm. An outflow from the flowery kingdom is conceivable which would make prudent an Anglo-Saxon union. Australia and New Zealand confront a danger close at hand, with which to cope unassisted may become a task quite beyond their power. They may need behind them more even than the power of England, tied as the hands of England are liable to be through European complications that may any day arise. "Blood is thicker than water," said the American naval captain at the mouth of the Pei-ho, thirty years ago, when an English squadron was in difficulties with the Chinese forts; and he carried his ships to their assistance. The course of the captain was

1 Our Kin across the Sea, p. 181, etc. 
sustained at home. Blood should be held to be thicker than water in such a erisis as has been described. Our eourse toward Asia has been full of selfish blundering. The Anglo-Saxon deserves to suffer; he does not, however, deserve to be permanently erippled. Could the greatest of English-speaking lands look on unmoved while a Mongolian dominion was established in the South Pacific over AngloSaxon ruins? Such a danger is not probable, but only possible. Let us pass, however, to the consideration of a peril similar in kind, which is more liable to be sometime imminent.

Gladstone remarked not long since that the vital forees of Europe are becoming exhausted; that the bone and sinew have gone to Ameriea, Asia, Afriea, or Australia; that only two nations know how to eolonize - England and Russia; that they therefore alone have any future; that other nations are on the decline; and the time is not far off when they will lisalpear from Russa. among first-class powers. ${ }^{1}$ It is an ungracious thing to say, but much ean be affirmed to sustain the position, that of European nations, only England and Russia have a great future. All others are confined within narrow limits. "In the matter of colonies more than anything else, the proverb 'Turde venientibus oxsa' holds goods. England long ago swallowed all the fat piekings and left only meagre gleanings." 2 For other European people, Russial excepterl.

1 Novö̈ Vremya, of St. Petersburg, quoted by W. I). Foulk". "Slav or Saxon," p. 1.

2 Vambery in "The Formm," November, 18\$8, art. "Is the Power of

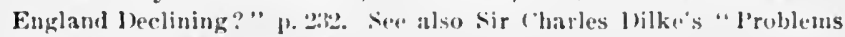
of Greater Britain," pp. 1 and kin. 
there is now no room for expansion were the ability to colonize ever so marked. No one fails to see the greatness of Russia and the certainty that it is to increase. In fact, there is no parallel in the history of the world to the growth of this centralized despotism; already it possesses nearly one-sixth part of the land on the globe, a territory lying contiguous, and however unfitted in parts for human occupancy through cold and sterility, to a large extent possessing all the conditions for calling out the utmost vigor of men. Her natural resources are boundless; both in Europe and Asia, Russia is for the most part a vast plain, much of which is very fertile, well watered, in every way fitted for agriculture; as to mineral wealth, no other land of the earth, probably, holds such stores of coal, iron, oil, silver, and gold.

The Slavic race, ignorant and strangely docile, full of patience and fortitude, is characterized also by a sketch of mighty energy, sluggish, indeed, but endurRussia. ing to the end, and submitting itself readily to outside guidance. Singularly enough, in Russia may be found a vigorous form of local self-government. The town-meeting in its best days was scarcely more alive in New England than in the mir, or Russian village. The tun-moot has always been held to be the best possible school for freedom, but in Russia freedom stops with the mir. Almost exclusively the people cultivate the soil: there is too little diversity of occupation to call out intelligence. The vast stretches of the empire prevent the contact of part with part, in friction which might strike out sparks of civilization. Whereas, among the Angles and Saxons, above the primary moot, came the moots of 
hundred, shire, and of the nation, the primitive Slavs stopped with the first step: the small neighborhoods, instead of uniting, were hostile to one another; so torn by dissensions in fact that the aid of foreigners was invoked to avert intolerable disorder. Hence the introduction, in the ninth eentury, of the line of Rurik, from Seandinavia, - still another of those brilliant, ubiquitous Norsemen, who gave the early mediaval world so many leaders. A period of Tartar domination followed, - of mereiless severity, - passing a way at last, but leaving a people aceustomed to an absolute, centralized tyranny under which they were depressed into utter serfdom. A sort of feudal system introduced by the line of Rurik survived the Tartar rule, and ont of this eame the nobility. As our own times are apluroached, Russia offers the speetacle of a people of serfs, bound to the soil and there regulating their life in the mirs, but with an absolute lord over them in the Czar, to Threalening character of whom they look as a sacred, almost a suher vast de. pernatural personage. A class of nobles, separated from the preople ly an impassable gulf, exists, but of a free middle class there is no trace. Though serfdom has been abolished, the pople are seareely raised. The antoratey of the Czar, on the other hambl. hats been strengthened through the diminution of the gower of the nobles, whose lands have lne'n bestowed upon the peasants. The preople are troaterl as if they were minors. "Neither a chatre in at college nol" a bed in a hospital can he endowed withont the intervention of the state." The Russian, all his life, is " like a soldier in his regriment, who matehes, halts, anrances, retreats, lifts his leg or his foot at the com- 
mand of the instructing sergeant." Under Nicholas, not a house of more than five windows could be built without govermment leave. Nine-tenths of the Russians are a peasantry, wholly ignorant, with habits of submission as a part of their very fibre. The moral and physical power of the Czar over them in the intense centralization is never relaxed. They are held as in a vice. As civilization grows in Russia, by a strange inversion it seems at present only to erect new bulwarks about despotism. The advance of knowledge "appears only to strengthen the hand of the master." The development of agriculture only fastens the peasant more firmly to the soil ; the opening of mines only adds horror to penal servitude; the introduction of steam and electricity, the central power controlling all means of intercommunication, only enables the autocrat to bring to bear his authority more easily upon any point he wishes to reach.

There is something awe-inspiring in the enormousness of the might which the autocrat of all the Russias is so rapidly rolling up. His subjects at present number one hundred and sixty million of souls living under conditions, indeed, beset with difficulties, but only such as serve to call into their best exercise the human energies, upon a territory so vast that even these multitudes seem a very sparse population. The Slav has extraordinary assimilating power. Eighty different races once occupied the empire, but there is not one which the Slav has not swallowed, or is not on the point of swallowing, making it in language, in body, and in soul, part of himself. Even the Anglo-Saxon appears to have no such power of 
assimilation. The Russians, proceeding from the little plateau of Valdai, in the northwest of European Russia, southward over such immense tracts, remain Russians still, only strengthened by what they have absorbed. There is no limit to Russia's aggressiveness. It rolls out of the north like a snow-ball, cold before civilization, in each decade a more crushing weight, always gathering a greater and greater volume. In the village communities land is assigned to families in proportion to their size, - a provision most favorable to multiplication.

What if, in another hundred years, Russia should become the dominant power of the world: It is worth while to scan closely the features of the empire which may be able, and is very likely to have the will, to reduce the human race to vassalage. Is there any hope that anything less dreary can come about in its social condition, a condition which it may have the power a century from now to attempt to make universal? No hope, except from that little class whom we have learned to regard with terror. the Nihilists. They belong to the small number of elucated men and women, for the most part nobles. Their effort is desperate, undertaken in the face of risks which have been presented to the world by most graphice pens and peneils. Often they are truly self-salcrifieing, alding in behalf of the peasants for whom they desire to shape a higher life. It has

1 The following demanls are said to have boun lad before dhe present Czar at his acession by the cxecutive commitere of the Nihilists:-

1. A general ammesty for politial offenters, and a convention of representatives of the poople to exanine the best forms of social and political life; to this convention deputies to be elosen by all classes without distinction. 
been well said that in their methods they are to be compared with John Brown. Like him, the impulse is the best; but maddened at the magnitude of the obstacles, they pursue almost the methods of insanity.

Such is Russia in her constitution, such in her history, such in her prospects. Shall we calmly say that the Anglo-Saxon race has no duty before it in view of such facts? It would be humiliation unspeakable to see the Czar installed in the position of dictator of the world, with submissive Englishspeaking races crouching at his footstool. Pride, however, is a low motive to which to appeal. We believe that the welfare of the human race is bound up with the development of Anglo-Saxon freedom. At present the Anglo-Saxon world is sharply sundered, the inharmonious parts holding one another aloof; and though substantially one in language, literature, institutions, and every detail of life, nursing old prejudices that promote a harmful fret. Though, to be sure, England confronts the one hundred and sixty million of Russia with three hundred million in her own empire, yet two hundred and fifty million of these are the Asiatics, over whom her dominion is confessed to be so precarious that it may be dissolved in an hour. Said Lord Randolph Churchill, of British dominion in India, "It is a thin coat of oil on the surface which preserves the calm of an ocean

2. No restriction of any kind on electors or deputies.

3. The government to grant, as provisional regulations, complete freedom of speech, of the press, and of public meeting.

The Nihilists solemnly promise to submit unconditionally to the decision of such an assembly as regards a proper constitution for Russia. 
of humanity and controls its storms." Undoubtedly, British rule has been beneficent; order has come out of ehaos; justice out of rapine; humanity after the spirit of murder. No bond of any strength, however, it is confessed, binds the confusion of Mahometans and idol-worshippers of a hundred kinds, to the whitefaced strangers who have come among them. A few hundred civil officials, a few thousand soldiers seattered about the immense peninsula, wield the power of England, their only safety being that the mastered cannot combine against them. But any day the closing hour of the English rule in India may strike. In 1857, that power hung by a hair, and its condition may any day be again as preearious.

The Anglo-Saxons of the British empire are some sixty millions, as the Americans are some sixty millions. It is only upon that stock and upon those whom that stock has assimilated that dependence can be placed. Russia alone nearly or quite at the present hour balanees the two together. Whose chances are to-day the more promising for rapid growth in the near future into compract, effective might, - those of the Slav or the Anglo-Sixon? Ilave we not here a consideration worth weighing in favor of Anglo-Saxon fraternity, in the expediency of making a good front against the Slav?

It is not merely or mainly fighting the slat of which the Anglo-saxon should think. Of eomerse, we will fight rather than go down, if barbarian Russia, having beeome still more the colossts of mations, is as ready with her bayonets in the future as she hats been in the past. It is lecter, however, to think of the indirect but mighty influence which would go 
forth into Russia, from a league of free states so powerful that she would be forced to respect them. Russia has the germs within her of freedom. Her vast hordes of peasants are capable of being guided into a free life. Among her nobles are heroes ready in the most desperate times, even to face torture and death to break the chains. In the line of Czars, even, come characters like Catharine and Alexander, of a humane and liberal spirit. Now, all free dispositions seem to be forced back. A noble youth comes upon the throne and begins reforms; but overcome by his environment, he soon grows reactionary: patriots, discouraged, fall into the madness of nihilism. Meantime, the vast despotism, in spite of the disintegrating forces within itself, keeps heaping up power upon power. If it becomes dominant, with nothing in the world that it needs to fear, how faint the likelihood that it can improve from within! Confronted, however, by freedom, as well armed as itself, as compact, as numerous, what hope that the forces within that make for good will at last prevail! An Anglo-Saxon fraternity must not come about in obedience to a low race pride. If that were the motive, the Slav would be more worthy to rule than we; for each one of those million soldiers is ready to give up life in a pathetic and thoroughly honest enthusiasm for holy Russia as the worthy mistress of nations. Is it beyond hope that if Anglo-Saxons must sometime confront Russia, they nay feel an enthusiasm equally honest and unselfish, while standing for ideas which are to bless mankind?

Tennyson sung in his youth of - 
"The parliament of man, the federation of the world,"

so far, no doubt, a Utopian dream, but who will say it may not some time be approached? Said Lessing once, in words which have often been regarded as startling, "According to my way of thinking the reputation of a zealous patriot is $\begin{gathered}\text { Goethe on the } \\ \text { virtue of pa- }\end{gathered}$ the very last that $I$ would covet; that is, trlotism. of patriotism which teaches me to forget that I am a citizen of the world." ' Lessing's heart demanded something far broader than what often passes under the name of patriotism. He loved to call himself a cosmopolite, and any national feeling which interfered with the most liberal humanity, love for the entire race, he felt to be vicious. He asserted that in history the individual had often been sacrificed to the State, and entertained the idea that a bocly of superior men might be constituted in every nation who should live above all narrowness, and striving to draw mankind into a brotherhood, should work together for the abrogation of national lines.- In a similar spirit Goethe exelaimed: "Altogether, mational latred is a emrons thing. You will always find it strongest and most violent in the lowest stage of enlture. But there is a stage where it vanishes completely, and where one feels himself to a certain extent above nations, and feels the weal and woe of a noighboring people as one's own. This degree of culture was conformable to my nature, and I laul been strengthened in it long lnefore my sixtieth year."

Who will maintain that a great part of what has passed in the world for patriotism, and been pratised 
to the skies as one of the chief of virtues, is, after all, Love of anything else than an expansion of selfishhigher than ness? The selfish man, pure and simple, lore of coun. . try. ${ }^{\text {lofe coun- }}$ is he who has no thought beyond what is wrapped in his own skin, and is utterly careless as to whether all beside flourish or suffer. Such unmixed selfishness, however, we may be sure, rarely, perhaps never, appears. Each human being has a certain environment, - his family, his religious sect, his political party, the State of which he is a citizen, - which he identifies with himself, and for whose welfare he schemes and labors. No doubt selfishness broadens toward a noble principle in proportion as the individual includes within the circle of his regard a wider and wider circle. Tet in the highest view, any limitation of the sympathies is to be regretted which prevents a thorough, generous going out of the heart toward the whole human race. In the great teacher, Christ, the eminent beauty is that from him love goes forth unrestrained; it knows no linits of family, city, country, or race. It is easy to conceive of a love of family, or of class, or of courtry, which may have a most unamiable side. When the riches of a man's heart are quite exhausted within these narrow circles, leaving only coldness or hatred for the world beyond, we see simply an expansion of selfishness, - more amiable, no doubt, than regard that is entirely self-centred, but a sentiment short of the highest. "A single life," says Lord Bacon, "docth well with churchmen, for charity will hardly water the ground where it must first fill a pool." 1 The philosopher has in mind the wealiness of human

1 Essays; "Of Marriage and Single Life." 
nature, and asserts that a man surrounded by a family will of neeessity exhaust his love within the confined eircle, having none left for the world at large; hence, let the priest, who should in an especial way be the servant of humanity, be a celibate. The ideal soul, however, it may be replied, will possess a store of eharity so abundant that the needs of the ground will be met as well as of the pool. It is something toward which the world must grow. The doetrine of Lessing and Goethe, now no doubt impracticable, we can yet see is elevated teaching, to follow which will not always be beyond the power of man. Look carefully at what has been admired as patriotism. If we go to Greece, how many are there among her heroes who, when they give themselves to sword or spear, have a thought beyond Greee? Bápßapo are all others, not precious and worthy to die for. If we go to Rome, it is simply for Rome that the heroes die, - for country; but there is no thought beyond the country. To die for that was the last refinement of the Roman virtus, the sublimest limit of honor. If the eountry were wrong, if it stood as a curse in the world rather than a blessing, it was the same. So the wild IIighlander or semi-barbarian mediaval prince for his first virtue held loyalty to his elan or gens, - Cimploell or Gordon, Orsini or Colomna, York or Lancaster: or to his suzerain lord, - confronting all else with the spear-point and the axe's edger. Louis XIV lived, ats he thomeght, for France, and to angrandize her latel waste the wortel elsewhere with tire and sword; and low often in every civilized land has at narrow national fecling in the hearts of soldiers and statesmen, baptized by a 
name held in honor, and lauded as a virtue beyond all price, brought misery upon millions!

There are signs, however, of something better. Our age is noteworthy through its tendency to unifiBlessings of cation. Through Cavour, disintegrated Italy unitication. has come together into a great and powerful kingdom under the leadership of the able house of Savoy. Still more memorably, Germany has been redeemed from the granulation which for so many ages past has made her a mere rope of sand, her petty principalities and kingdoms becoming plaited at length into a nation magnificent in size, power, and ability. Such coalescing can be regarded as only advantageous, if we look toward the general welfare of the human race. The blending of small nationalities into great States, and of States into still larger unions, which marks the world to-day, is a subject for rejoicing; because by such a gradual coalescing of related parts we are advancing toward a time when narrowing lines shall be done away, and men sit down together as one family.

Humanity at large will be benefited, but still more than this. By such political unification, the individual man is enlarged and lifted up. There is something in the remark of Froude: "The dimension and value of any single man depend upon the body of which he is a member. . . A A citizen of an imperial power expands to the scope and fulness of the larger organism, - the grander the organism, the larger and more important the unit that knows he belongs to it. His thoughts are wider, his interests less selfish, his ambitions ampler and nobler. .. . Behind each American citizen America is standing, and he knows 
it, - is the man that he is because he knows it. . . . A great nation makes great men; a small nation makes little men." 1

If the considerations presented have value, they weigh in favor of the position that English-speaking peoples should come into aceord. States For the abro. between which there exists some likeness $\begin{gathered}\text { gation of na- } \\ \text { lional distinc- }\end{gathered}$ must first draw toward one another, if the $\begin{gathered}\text { tions, like } \\ \text { must first seek }\end{gathered}$ world is to move in the direction of the like. fraternity of which the benevolent have dreamed. A brotherhood of humanity! How desirable a enlmination for the work of the high souls, who, during the two thousand years we have reviewed, have, each in his own generation, striven to sustain AngloSaxon freedom:

"The deatl of nations in their work began;

'They sowed the seed of federated man.

Dead nations were but selfish horles, and we

The first battalion of lumanity !

All living nations while our tokens shine, One after one shall wheel into our line;

Our free-born heritage shall be the guide

Ant bloodless order of their regicide.

'The seat shall join, not liuit; mountains stand

Dividling farm from farm, not land from land." 2

1 Oceana, pp. 335, 354;.

2 John boyle O'Reilly, Poem at Plymouth, August 1, 1589. 


\section{NOTE.}

Magka Cinarta, the Petition of Right, and the Bill of Rights were called by the Earl of Chatham the Bible of the English Constitution. Regarding, as is done in this book, the constitutional history of the entire Englishspeaking race, we can place two other memorable documents in the canon with the three mentioned. They are the Constitution of the United States, under which ordered liberty is secured for the larger division of the Englishspeaking race; and the British North American Act of 1867, which forms at present the Constitution of federated British America, and will, before long, probably furnish the model for the polity of Greater Britain in general. In the following Appendices, Magna Charta, the Petition of Right, and the Bill of Rights, are presented in full, the text in the case of Magna Charta being rendered from the Latin. The two remaining documents are too long to be reproduced here in full, and are therefore summarized. The résumé of the Constitution of the United States is based upon that of Professor Alexander Johnson, in the "Encyclopædia Britannica"; that of the Constitution of Canada, upon the abridgment, by the Hon. H. B. Witton of Ontario, contained in Lalor's "Cyclopædia of Political Science and Political Eeonomy." For the full text of the British North American Act of 1867, with an intelligent commentary, the reader is referred to the work of Hon. J. G. Bourinot, "The Constitution of Canada." 


\section{APPENDIX A.}

\section{MAGNA CHARTAI}

Or tue Great Ciarter of Kisg John, Graxted Jexe 15, A.D. 1215.

\section{(Translation from the Latin.)}

Jons, by the Grace of God, King of England, Lord of Ireland, Duke of Normandy, Aquitaine, anu Count of Anjou, to his Arehbishops, Bishops, Abbots, Earls, Barons, Jnsticiaries, Foresters, Sheriffs, Governors, Officers, and to all Bailiffs, and his faithenl subjeets, greeting. Know ye, that we, in the presence of God, and for the salvation of our soul, and the souls of all our ancestors and heirs, and unto the honour of God and the advancement of Holy Church, and amendment of our Realm, by alvice of our venerable Fathers, Stephen, Archbishop of Canterbury, Primate of all England and Cardinal of the Holy Roman Chureh; Ilenry, Arehbishop of Dublin; William, of London ; Peter, of Winchester; Jocelin, of Bath and Glastonbury ; Ifneh, of Lineoln ; Walter, of Woreester; William, of Cowntry; Benedict, of liohester-Bishops: of Master Pandulph, Sul-Deacon and Familiar of our Lard the Iope; Brother Aymeric. Naster of the Knights-Templars in England; and of the neble P'rsons, William Marescall, Larl of Pembroke; Willian, Sart of sialisbury; William, Larl of Warren; Willian, Farl of Arumlel; Alan de Galloway, Constable of Seotland; Warin FitzGerahl, Poter Fitzllerbert, and Hubert de Bursh, Seneschal of l'oitou; lugh de xeville, Matthew Fitzllerlert,

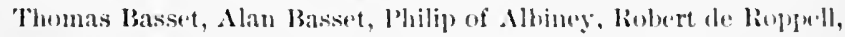
John Mareschal, John FitzHhgh, and others, our liegunen, have, in the first place, grinted to God, and by this onr present ('larter confirmet, for us and our heirs for ever:-

1. That the ('hurch of England shall he frese, and have her whole rights, and her liberties inviolahle; and wir will have them

$$
\text { IOld Soubh Leatlets, Cieneral Neries, No. } 3 .
$$


so observed, that it may appear thence that the freedom of elections, which is reckoned chief and indispensable to the English Church, and which we granted and confirmed by our Chartcr, and obtained the confirmation of the same from our Lord the Pope Innocent III., before the discord between us and our barons, was granted of mere free will; which Charter we shall observe, and we do will it to be faithfully observed by our heirs for ever.

2. We also have granted to all the freemen of our kingdom, for us and for our heirs for ever, all the underwritten liberties, to be had and holden by them and their heirs, of us and our heirs for ever: If any of our earls, or barons, or others, who hold of us in chief by military service, shall die, and at the time of his death his heir shall be of full age, and owe a relief, he shall have his inheritance by the ancient relief - that is to say, the heir or heirs of an earl, for a whole earldom, by a hundred pounds; the heir or heirs of a baron, for a whole barony, by a hundred pounds; the heir or heirs of a knight, for a whole knight's fee, by a hundred shillings at most; and whoever oweth less shall give less, according to the ancient custom of fees.

3. But if the heir of any such shall be under age, and shall be in ward, when he comes of age he shall have his inheritance without relief and without fine.

4. The keeper of the land of such an heir being under age, shall take of the land of the heir none but reasonable issues, reasonable customs, and reasonable services, and that without destruction and waste of his men and his goods; and if we commit the custody of any such lands to the sheriff, or any other who is answerable to us for the issues of the land, and he sliall make destruction and waste of the lands which he hath in custody, we will take of him amends, and the land shall be committed to two lawful and discreet men of that fee, who shall answer for the issues to us, or to him to whom we shall assign them; and if we sell or give to any one the custody of any such lands, and he therein make destruction or waste, he shall lose the same custody, which shall be committed to two lawful and discreet men of that fee, who shall in like manner auswer to us as aforesaid.

5. But the keeper, so long as he shall hare the custody of the land, shall keep up the houses, parks, warrens, ponds, mills, and other things pertaining to the land, out of the issues of the same land; and shall deliver to the heir, when he comes of full age, his whole land, stocked with ploughs and carriages, according as the 
time of wainage shall require, and the issues of the land can reasonably bear.

6. Ileirs shall be married without disparagement, and so that before matrimony shall be contracted, those who are near in blood to the heir shall have notice.

7. A widow, after the death of her husband, shall forthwith and without difticulty have her marriage and inheritance; nor shall she give anything for her lower, or her marriage, or her inheritance, which her husband and she held at the day of his death; and she may remain in the mansion house of her husband forty days after his death, within whieh time her dower shall be assigned.

8. No widow shall be distrained to marry herself, so long as she has a mind to live withont a husband; but yet she shall give security that she will not marry without our assent, if she hold of us; or without the consent of the lord of whom she holds, if she hold of another.

9. Neither we nor our bailiffs shall seize any land or rent for any debt so loug as the chattels of the debtor are suftieient to pay the debt; nor shall the sureties of the debtor be distrained so long as the principal debtor has suffieient to pay the debt; and if the prineipal debtor shall fail in the payment of the debt, not having wherewithal to pay it, then the sureties shall answer the debt; and if they will they shall have the lands and rents of the debtor, until they shall be satisfied for the debt which they paid for lim, unless the principal debtor can slow himself aequitted thereof against the sail sureties.

10. If any one lave borrowed anything of the Jews, more or less, and die before the debt be satisfied, there shall be no interest paid for that debt, so long als the heir is under age, of whomsoever he may hold; and if the debt falls into our hamls, we will only take the chattel mentioned in the deed.

11. And if any one shall die indebted to the Jews, his wife shall have her dower and pay nothing of that debt; and if the deceased left elilden wuder age, they shall have neessiries provided for then, aceording to the tenement of the decentsed; and ont of the residue the debt shall be paid, saving, however, the service due to the lords, and in like mamner shall it be done touching dehts due to others than the Jews.

12. Xo sentage or aid shall be inposed in rour kingdnm, unless by the general eouncil of our kingdom; except for lansoming our person, making our cldest sum a kuight, and onee for marrying our 
eldest daughter; and for these there shall be paid no more than a reasonable aid. In like manner it shall be concerning the aids of the City of London.

13. And the City of London shall have all its ancient liberties and free customs, as well by land as by water: furthermore, we will and grant that all other cities and boroughs, and towns and ports, shall have all their liberties and free customs.

14. And for holding the general council of the kingdom concerning the assessment of aids, except in the three cases aforesaid, and for the assessing of scutages, we shall cause to be summoned the archbishops, bishops, abbots, earls, and greater barons of the realm, singly by our letters. And furthermore, we shall cause to be summoned generally, by our sheriffs and bailiffs, all others who hold of us in chief, for a certain day, that is to say, forty days before their meeting at least, and to a certain place; and in all letters of such summons we will declare the cause of such summons. And summons being thus made, the business shall proceed on the day appointed, according to the advice of such as shall be present, although all that were summoned come not.

15. We will not for the future grant to any one that he may take aid of his own free tenants, unless to ransom his body, and to make his eldest son a knight, and once to marry his eldest daughter; and for this there shall be only paid a reasonable aid.

16. No man slall be distrained to perform more service for a knight's fee, or other free tenement, than is due from thence.

17. Common pleas shall not follow our court, but shall be holden in some place certain.

18. Trials upon the Writs of Novel Disseisin, ${ }^{1}$ and of Mort d'ancestor, ${ }^{2}$ and of Darrein Presentment, ${ }^{3}$ shall not be taken but in their proper counties, and after this manner: We, or if we should be out of the realm, our chief justiciary, will send two justiciaries through every county four times a year, who, with four knights of each county, chosen by the county, shall hold the said assizes ${ }^{4}$ in the county, on the day, and at the place appointed.

19. And if any matters cannot be determined on the day

1 Dispossession.

2 Death of the ancestor; that is, in cases of disputed succession to land.

${ }^{3}$ Last presentalion to a benefice.

"The word Asslze here means "an assembly of knights or other substantial persons, held at a certain time and place where they slt with the Justice. 'Assiea' or 'Assize ' is also taken for the court, place, or time at which the write of Assize are taken." - Thompson's Notes. 
appointed for holding the assizes in each county, so many of the knights and freeholders as have been at the assizes aforesaid shall stay to decide them as is necessary, according as there is more or less business.

20. A freeman shall not be amerced for a small offence, but only according to the degree of the offence; and for a great crime according to the heinousness of it, saving to him his contenement ${ }^{1}$ and after the same manner a merchant, saving to him his merchandise. And a villein shall be amerced after the same manner, saving to him his wainage, if he falls under our mercy ; and none of the aforesaid amerciaments shall be assessed but by the oath of honest men in the neigh bourhood.

21. Earls and barons shall not be amerced but by their peers, and after the degree of the offence.

22. No ecclesiastical person shall be amerced for his lay tenement, but according to the proportion of the others aforesaid, and not accorling to the value of his ecclesiastical benefice.

23. Neither a town nor any tenant shall be distrained to make bridges or embankments, unless that anciently and of right they are bound to do it.

24. No sheriff, constable, coroner, or other our bailiffs, shall hold "Pleas of the Crown.",

25. All comnties, hundreds, wapentakes, and trethings, shall stand at the old rents, without any increase, except in our demesne manors.

26. If any one holding of us a lay fee die, and the sheriff, or our bailiffs, show our letters patent of summons for debt which the Ilead man dis owe to us, it slatl be lawful for the sheriff or our bailiff to attach and register the chattels of the dead, found upon his lay fee, to the anount of the delst, by the view of lawful men, so as nothing be removed nntil our whole clear debt be paid ; and the rest shall he left to the exeeutors to fulfil the testament of the dearl; and if there be nothing due from him to us, all the chattels shall go to the use of the dead, saving to his wife and children their reasonable shares. ${ }^{3}$ nife."

1 "That by which a person subaints and which is earentlal to has rank in

${ }^{2}$ These are suits conducted in the name of the Crown against criminal offenders.

${ }^{3} A$ person's goods were dislded into three parts, of which one went to his wife, nnother to hie heirs, and a third he was at liberly to thapose of. If he had no child, his widow had half; and If he had children, but no wife, half was 
27. If any freeman shall die intestate, his chattels shall be distributed by the hands of his nearest relations and friends, by view of the Church, saving to every one his debts which the deceased owed to him.

28. No constable or bailiff of ours shall take corn or other chattels of any man unless he presently give him money for it, or hath respite of payment by the good-will of the seller.

29. No constable shall distrain any knight to give money for castle-guard, if he himself will do it in his person, or by another able man, in case he cannot do it through any reasonable cause. And if we have carried or sent him into the army, he shall be free from such guard for the time he shall be in the army by our command.

30. No sheriff or bailiff of ours, or any other, shall take horses or carts of any freeman for carriage, without the assent of the said freeman.

31. Neither shall we nor our bailiffs take any man's timber for our castles or other uses, unless by the consent of the owner of the timber.

32. We will retain the lands of those convicted of felony only one year and a day, and then they shall be delivered to the lord of the fee. ${ }^{1}$

33. All kydells ${ }^{2}$ (wears) for the time to come shall be put down in the rivers of Thames and Medway, and throughout all England, except upon the sea-coast.

34. The writ which is called procipe, for the future, shall not be made out to any one, of any tenement, whereby a freeman may lose his court.

35. There shall be one measure of wine and one of ale through our whole realm; and one measure of corn, that is to say, the London quarter; and one breadth of dyed cloth, and russets, and

divided amongst them. These sereral sums were called "reasonable sbares." Through the testamentary jurisdiction they gradually acquired the clergy often contrived to get into their own bands all the residue of the estate witbout paying the debts of the cstate.

1 All forfeiture for felony has been abolished by the 33 and 34 Vic. c. 23. It seems to have originated in the destruction of the felon's property being part of the sentence, and this "waste" belng commuted for temporary possession by the Crown.

2 The purport of this was to prevent enclosures of common property, or com. mlttlng a "Purpresture." These wears are now called " kettles" or "kettlenete" in Kent and Cornwall. 
haberjeets, that is to say, two ells within the lists; and it shall be of weights as it is of measures.

36. Nothing from henceforth shall be given or taken for a writ of inquisition of life or limb, but it shall be granted freely, and not denied. ${ }^{1}$

37. If any do hold of us by fee-farm, or by socage, or by burgage, and he hold also lands of any other by knight's service, we will not have the custody of the heir or land, which is holden of another man's fee by reason of that fee-farm, socage, ${ }^{2}$ or burgage; neither will we have the custody of the fee-farm, or socage, or burgage, unless knight's service was due to us out of the same feefarm. We will not have the custody of an heir, nor of any land which he holds of another by knight's service, by reason of any petty serjeanty ${ }^{3}$ by which he holds of us, by the service of paying a knife, an arrow, or the like.

38. No bailiff from lenceforth shall put any man to his law 4 upon his own bare saying, without credible witnesses to prove it.

39. No freeman shall be taken or imprisoned, or disseised, or outlawed, or banished, or any ways destroyed, nor will we pass upon him, nor will we send upon him, unless by the lawful judgment of his peers, or by the law of the land.

40. We will sell to no man, we will unt deny to any man, either justice or right.

41. All merchants shall have safe and secure conduct, to go out of, and to come into Fngland, and to stay there and to pass as well by land as by water, for buying and selline by the ancient and allowed eustoms, without any unjust tolls ; except in time of war, or when they are of any nation at war with us. And if there be found any such in our lard, in the beginning of the war, they shall be attached, withut damage to their herlies or sonds, mutil it he known unto us, or our chief justiciary, low our merchants be treated in the nation at war with us; and if ours be safe there, the others shall be safe in our dominions.

1Thls inportant writ, or " writ concerning hatred and malice," may have been the prototype of the writ of llabeas (orpus, and was granted for a similar purpose.

2 "socage" signifies lands hell by tenure of performing certain inferior oftices in husbandry, probatily from the old French word soc, a llungh-mare.

3Te tenure of giving the hing some small weapon of war in acknowledg. ment of lands held.

'Equiralent to putting him to his oath. Thls alludes to the Wager of Iaw, by whlch a defendant and his eleven supporters or " compurgators" could wear to his nonflabllity, and thls amounted to a verdict in his faror. 
42. It shall be lawful, for the time to come, for any one to go out of our kingdom, and return safely and securely by land or by water, saving his allegiance to us; unless in time of war, by some short space, for the common benefit of the realm, except prisoners and outlaws, according to the law of the land, and people in war with us, and merchants who shall be treated as is above mentioned.1

43. If any man hold of any escheat, ${ }^{2}$ as of the honour of Wallingford, Nottingham, Boulogne, Lancaster, or of other escheats which be in our hands, and are baronies, and die, his heir shall give no other relief, and perform no other service to us than he would to the baron, if it were in the baron's hand; and we will hold it after the same manner as the baron held it.

44. Those men who dwell without the forest from henceforth shall not come before our justiciaries of the forest, upon common summons, but such as are impleaded, or are sureties for any that are attached for something concerning the forest. ${ }^{3}$

45. We will not make any justices, constables, sheriffs, or bailiffs, but of such as know the law of the realn and mean duly to observe it.

46. All barons who have founded abbeys, which they hold by charter from the kings of England, or by ancient tenure, shall have the keeping of them, when vacant, as they ought to have.

47. All forests that have been made forests in our time shall forthwith be disforested; and the same shall be done with the water-banks that have been fenced in by us in our time.

48. All evil customs concerning forests, warrens, foresters, and warreners, sheriffs and their officers, water-banks and their kecpers, shall forthwith be inquired into in each county, by twelve sworn knights of the same county, chosen by creditable persons of the same county; and within forty days after the said inquest be utterly abolished, so as never to be restored: so as we are first

1 The Crow $n$ bas still technically the power of confining subjects within the kingdom by the writ " ne exeat regrio," though the use of the writ is rarely resorted to.

2 The word escheat is derived from the French escheoir, to return or bappen, and slgnifies the return of an estate to a lord, either ou failure of tenant's issue or on his committing felony. The abolition of Fendal tenures by the Act of Charles II. (12 Charles II. c. 24) rendered obsolete this part and many other parts of the Charter.

3 The laws for regulating the Royal forests, and administcring justice in respect of offences committed in their precincts, formed a large part of the law. 
aequainted therewith, or our justiciary, if we should not be in England.

49. We will immediately give up all hostages and eharters delirered unto us by our English subjeets, as seeurities for their keeping the peace, and yielding us faithful service.

50. We will entirely remove from their bailiwieks the relations of Gerard de Atheyes, so that for the future they shall have no bailiwick in England; we will also remove Engelard de Cygony, Andrew, Peter, and Gyon, from the Chancery ; Gyon de Cygony, Geoffrey de Martyn, and his brothers; Philip Mark, and his brothers, and his nephew, Geoffrey, and their whole retinue.

51. As soon as peace is restored, we will send out of the kingdom all foreign knights, eross-bowmen, and stipendiaries, who are come with horses and arms to the molestation of our people.

52. If any one has been dispossessed or deprived by us, without the lawful judgment of his peers, of his lands, eastles, liberties, or right, we will forthwith restore them to him; and if any dispnte arise upon this head, let the matter be decided by the five-andtwenty barons hereafter mentioned, for the preservation of the peace. And for all those things of which any person has, without the lawful judgment of his peers, been dispossessed or deprivel, either by our father king Henry, or our brother King Richard, and which we have in our hands, or are possessed by others, and we are bound to warrant and make good, we shall have a respite till the term usually allowed the erusaders; exeepting those things about which there is a plea depenting, or whereof an inquest hath been made, by our order before we undertook the erusade; but as soon as we return from our expedition, or if perehance we tary at home and do not make our expedition, we will immediately cause full justiee to be administered therein.

53. The sane respite we shall have, and in the same mamer, about administering justice, disafforesting or letting continue the forests, which IJenry our father, and unr brother Riehard, have afforested; and the same eoncenning the warlship of the lands which are in another's fee, but the warlship of which we have hitherto had, by reason of a fee held of us by knight's service; and for the abbeys founded in any otluer fee than our own, in whieh the lord of the fee says he has a right; and when we return from our expedition, or if we tarry at hone, and du not make our expedition, we will immediately do full justiee to all the complainants in this behalf. 
54. No man shall be taken or imprisoned upon the appeal ${ }^{1}$ of a woman, for the death of any other than her husband.

55. All unjust and illegal fines made by us, and all amerciaments imposed unjustly and contrary to the law of the land, shall be entirely given up, or else be left to the decision of the five-andtwenty barons hereafter mentioned for the preservation of the peace, or of the major part of them, together with the aforesaid Stephen, Archbishop of Canterbury, if he can be present, and others whom he shall think fit to invite; and if he cannot be present, the business shall notwithstanding go on without him; but so that if one or more of the aforesaid five-and-twenty barons be plaintiffs in the same cause, they shall be set aside as to what concerns this particular affair, and others be chosen in their room, ont of the said five-and-twenty, and sworn by the rest to decide the matter.

56. If we have disseised or dispossessed the Welsh of any lands, liberties, or other things, without the legal judgment of their peers, either in England or in Wales, they shall be immediately restored to them; and if any dispute arise upon this head, the matter shall be determined in the Marches by the judgment of their peers; for tenements in England according to the law of England, for tenements in Wales according to the law of Wales, for tenements of the Marches according to the law of the Marches: the same shall the Welsh do to us and our subjects.

57. As for all those things of which a Welshman hath, without the lawful judgment of his peers, been disseised or deprived of by King Henry our father, or our brother King Richard, and which we eithêr have in our hands or others are possessed of, and we are obliged to warrant it, we shall have a respite till the time generally allowed the crusaders ; excepting those things about which a suit is depending, or whereof an inquest has been made by our order, before we undertook the crusade: but when we return, or if we stay at home without performing our expedition, we will immediately do them full justice, according to the laws of the Welsh and of the parts before mentioned.

58. We will without delay dismiss the son of Llewellin, and all the Welsh hostages, and release them from the engagements they have entered into with us for the preservation of the peace.

1 An Appeal here means an "accusation." The Appeal here mentioned was a suit for a penalty in which the plaintiff was a relation who had suffered through a murder or manslaughter. One of the incidents of this "A Apeal of Death" was the Trial by Battle. These Appeals and Trial by Battle were not abolished before the passing of the Act 59 Geo. III. c. 46 . 
59. We will treat with Alexander, King of Scots, concerning the restoring his sisters and hostages, and his right and liberties, in the same form and manner as we shall do to the rest of our barons of England; unless by the eharters which we have from his father, William, late King of Scots, it ought to be otherwise; and this shall be left to the determination of his peers in our court.

60. All the aforesaid customs and liberties, which we have granted to be holden in our kingdom, as much as it belongs to us, all people of our kingdom, as well clergy as laity, shall observe, as far as they are concerned, towards their dependents.

61. And whereas, for the honour of God and the amendment of our kingdom, and for the better quieting the discord that has arisen between us and our barons, we have granted all these things aforesaid; willing to render them firm and lasting, we do give and grant our subjects the underwritten security, namely that the barons may choose five-and-twenty barons of the kingdom, whom they think convenient; who shall take care, with all their might, to hold and observe, and canse to be observed, the peace and liberties we have granted them, and by this our present Charter confirmed in this manner; that is to say, that if we, our justiciary, our bailiffs, or any of our oftieers. shall in any circumstance have failed in the performance of them towards any person, or shall have broken through any of these artieles of peace and security, and the offence be notified to four barons chosen out of the fiveand-twenty before mentioned, the said four barons shall repair to us, or our justiciary, if we are out of the realm, and, laying open the grievance, shall petition to have it redressed without delay : and if it be not redressed by us, or if we should chance to be out of the realm, if it should not be redressed by our justiciary within forty diys, reckoning from the time it has been notified to us, or to our justiciary (if we should be out of the realm), the four barons aforesaid shall lay the cause before the rest of the five-and-twenty barons; amd the said five-and-twenty barons, together with the community of the whole kinulum, shall distrain and distress us in all the ways in which they shall he able, hy seizing our eastles, lands. possessions, and in any other manner they can, till the grievance is redressed, aceorling to their pleasure; saving harmbes our own person, and the persons of our Queen and children; and when it is redressed, they shall bohave to us as before. And any person whatsoever in the kinglom may swear that he will obey the orders of the five-and-twenty barons aforesaid in the execution of the 
premises, and will distress us, jointly with them, to the utmost of his power; and we give public and free liberty to any one that shall please to swear to this, and never will hinder any person from taking the same oath.

62. As for all those of our subjects who will not, of their own accord, swear to join the five-and-twenty barons in distraining and distressing us, we will issue orders to make them take the same oath as aforesaid. And if any one of the five-and-twenty barons dies, or goes out of the kingdom, or is hindered any other way from carrying the things aforesaid into execution, the rest of the said five-and-twenty barons may choose another in his room, at their discretion, who shall be sworn in like manner as the rest. In all things that are committed to the execution of these five-andtwenty barons, if, when they are all assembled together, they should happen to disagree about any matter, and some of them, when summoned, will not or cannot come, whatever is agreed upon, or enjoined, by the major part of those that are present shall be reputed as firm and valid as if all the five-and-twenty had given their consent ; and the aforesaid five-and-twenty shall swear that all the premises they shall faithfully observe, and cause with all their power to be observed. And we will procure nothing from any one, by ourselves nor by another, whereby any of these concessions and liberties may be revoked or lessened; and if any such thing shall have been obtained, let it be null and void; neither will we ever make use of it either by ourselves or any other. And all the ill-will, indignations, and rancours that have arisen between us and our subjects, of the clergy and laity, from the first breaking out of the dissensions between us, we do fully remit and forgive: moreover, all trespasses occasioned by the said dissensions, from Easter in the sixteenth year of our reign till the restoration of peace and tranquillity, we hereby entirely remit to all, both clergy and laity, and as far as in us lies do fully forgive. We have, moreover, caused to be made for them the letters patent testimonial of Stephen, Lord Archbishop of Canterbury, Henry, Lord Archbishop of Dublin, and the bishops aforesaid, as also of Master Pandulph, for the security and concessions aforesaid.

63. Wherefore we will and firmly enjoin, that the Church of England be free, and that all men in our kingdom have and hold all the aforesaid liberties, rights, and concessions, truly and peaceably, freely and quietly, fully and wholly to themselves and their heirs, of us and our heirs, in all things and places, for ever, as is afore- 
said. It is also sworn, as well on our part as on the part of the barons, that all the things aforesaid shall be observed in good faith, and without evil subtilty. Given under our hand, in the presence of the witnesses above named, and many others, in the meadow called Runingmede, between Windsor and Staines, the 15th day of June, in the seventeenth year of our reign.

\section{APPENDIX B.}

\section{THE PETITION OF RIGHT.}

A.D. 1628. 3 Car. I. c. 1.

The Ietition exhibited to his Majesty by the Lords Spiritual and Temporal, and Commons, in this present Parliament assembled, concerning divers Rights and Liberties of the Subjects, with the King's Majesty's royal answer thereunto in full Parliament.

\section{To the Kivg's Most Excelleyt Majesty.}

IIumbly show unto our Sovereign Lord the King, the Lords Spiritual and 'Temporal, and Commons in I'arliament assembled, that whereas it is declared and enacted by a statute made in the time of the reign of King Edward I, eommonly called Statutum de Tallagio non concedendo, that no tallage or aids shall be laid] or levied by the king or his heirs in this realm, witlout the good-will and assent of the archbishops, bishops, earls, barons, knights, burgesses, and other the freemen of the eommonalty of this realm; antl by authority of parliament holden in the five and twentieth year of the reign of King Edward Third, it is declared and enacted that from theneeforth no person shonlel be compelled to make any loans to the king against his will, beeause such loans were against reason and the franchise of the land; and by other laws of this realm it is provided, that none slowld be charged by any charge or imposition ealled a benevolenee, nor by such like charere; by which statutes before mentioned, and other the gord laws and statutes of this realm, your subjects have inherited this freedom, that they shonk not be comprebled to contribute to any tax, tallage, aicl, or other like charge not set by eommon consent, in parliament. 
II. Yet nevertheless of late divers commissions directed to sundry commissioners in several counties, with instructions, have issued; by means whereof your people have been in divers places assembled, and required to lend certain sums of money unto your Majesty, and many of them, upon their refusing so to do, have had an oath administered unto them not warrantable by the laws or statutes of this realm, and have been constrained to become bound and make appearance and give utterance before your Privy Council and in other places, and others of them have been therefore imprisoned, confined, and sundry other ways molested and disquieted; and divers other charges have been laid and levied upon your people in several counties by lord lieutenants, deputy lieutenants, commissioners for musters, justices of peace and others, by command or direction from your Majesty, or your Privy Council, against the laws and free customs of the realm.

III. And whereas also by the statute called "The Great Charter of the liberties of England," it is declared and enacted, that no freeman may be taken or imprisoned or be disseised of his freehold or liberties, or his free customs, or be ontlawed or exiled, or in any manner destroyed, but by the lawful judgment of his peers, or by the law of the land.

IV. And in the eight and twentieth year of the reign of King Edward III, it was declared and enacted by anthority of parliament, that no man, of what estate or condition that he be, should be put out of his land or tenements, nor taken, nor imprisoned, nor disherited, nor put to death without being brought to answer by due process of law.

V. Nevertheless, against the tenor of the said statutes, and other, the good laws and statutes of your realm to that end provided, divers of your subjects have of late been imprisoned without any cause showed; and when for their deliverance they were brought before your justices by your Majesty's writs of Habeas Corpus, there to undergo and receive as the court should order, and their keepers eommanded to certify the causes of their detainer, no cause was certified, but that they were detained by your Majesty's special command, signified by the lords of your Privy Couneil, and yet were returned back to several prisons, without being eharged with anything to which they might make answer according to the law.

VI. And whereas of late great companies of soldiers and mariners have been dispersed into divers counties of the realm, and the 
inhabitants against their wills have been compelled to receive them into their houses, and there to suffer them to sojourn against the laws and customs of this realm, and to the great grievance and vexation of the people.

VII. And whereas also by authority of parliament, in the five and twentieth sear of the reign of King Edward III, it is declared and enacted, that no man shall be forejudged of life or limb against the form of the Great Charter and the law of the land; and by the said Great Charter and other the laws and statutes of this your realm, no man ought to be adjudged to death but by the laws established in this your realm, either by the customs of the same realm, or by acts of parliament: and whereas no offender of what kind soever is exempted from the proceedings to be used, and punishments to be inflicted by the laws and statutes of this your realm; nevertheless of late time divers commissions under your Majesty's great seal have issued forth, by which certain persons have been assigned and appointel commissioners with power and authority to proceed within the land, according to the justice of martial law against such soldiers or mariners, or other dissolute persons joining with them, as should comunit any murder, robbery, felony, mutiny, or other outrage or inisdemeanor whatsoever, and by such summary course and order as is agreeable to martial law, and, as is used in armies in time of war, to proceed to the trial and condemnation of such offenders, and them to cause to be exeeuted and put to death according to the law martial.

VIII. By pretext whereof some of your Majesty's subjects have been by some of the said commissioners put to death, when and where, if by the laws and statutes of the land they have deserved death, by the same laws and statutes also they might, and by no other ought to have been judged and executed.

IX. And also sundry grievous offenders, by colour theren claiming an excmption, have escaped the punishnents dhe to them by the laws and statutes of this your realm, by reason that divers of your officers and ministers of justice have minjustly refused on forborne to preceed against such offenders according to the sime laws and statutes, unom pretene that the said offenders were punishable only by martial law, and by anthority of such eommissions as aforesabl: which commissions and all other of like nature are wholly and directly contrary to the saill laws and statedes of this your realm.

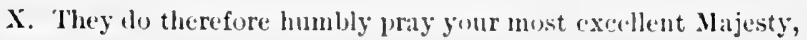


that no man liereafter be compelled to make or yield any gift, loan, benevolence, tax, or such like charge, without common consent by act of parliament; and that none be called to make answer, or take such oath, or to give attendance, or be confined, or otherwise molested or disquieted concerning the same or for refusal thereof; and that no freeman, in any such manner as is before mentioned, be imprisoned or detained ; and that your Majesty would be pleased to remove the said soldiers and mariners, and that your people may not be so burdened in time to come; and that the aforesaid commissions, for proceeding by martial law, may be revoked and annulled; and that hereafter no commissions of like nature may issue forth to any person or persons whatsoever to be executed as aforesaid, lest by colour of them any of your Majesty's subjects be destroyed or put to death contrary to the laws and franchise of the land.

XI. All which they most humbly pray of your most excellent Majesty as their rights and liberties, according to the laws and statutes of this realm; and that your Majesty would also vouclisafe to declare, that the awards, doings, and proceedings, to the prejudice of your people in any of the premises, shall not be drawn hereafter into consequence or example; and that your Majesty would be also graciously pleased, for the further comfort and safety of your people, to declare your royal will and pleasure, that in the things aforesaid all your officers and ministers shall serve you according to the laws and statutes of this realm, as they tender the honour of your Majesty, and the prosperity of this kingdom.

Qua quidem petitione lecta et plenius intellecta per dictum dominum regem taliter est responsum in pleno parliamento, viz. Soit droit fait come est desiré. Statutes of the Realm, v. 24, 25.

\section{APPENDIX C.}

\section{THE BILL OF RIGHTS.}

A.D. 1689. 1 Will, \& Mar. Sess, 2, c. 2.

Whereas the Lords Spiritual and Temporal, and Commons, assembled at Westminster, lawfully, fully, and freely representing all the estates of the people of this realm, did, upon the thirteenth 
day of February, in the year of our Lord one thousand six hundred eighty-eight, present unto their Majesties, then called and known by the names and style of William and Mary, Prince and Princess of Orange, being present in their proper persons, a certain declaration in writing, made by the said Lords and Commons, in the words following; viz :-

Whereas the late King, James II, by the assistance of diverse evil counsellors, judges, and ministers employed by him, did endeavour to subvert and extirpate the Protestant religion, and the laws and liberties of this kingdom:-

1. By assuming and exercising a power of dispensing with and suspending of laws, and the execution of laws, without consent of Parliament.

2. By committing and prosecuting divers worthy prelates, for humbly petitioning to be excused from concurring to the same assumed power.

3. By issuing and causing to be executed a commission under the Great Seal for erecting a court, called the Court of Commissioners for Ecclesiastical Canses.

4. By levying money for and to the use of the Crown, by pretence of prerogative, for other time, and in other manner than the same was granted by Parliament.

5. By raising and keeping a standing army within this kingdom in time of peace, without consent of Parliament, and quartering soldiers contrary to law.

6. By causing several good subjects, being Protestants, to be disarmel, at the same time when Papists were both armed and employed contrary to law.

7. By violating the freedom of election of nembers to serve in Parliament.

8. 13y prosecutions in the Court of King's Bench, for matters and canses eognizable only in Parliament; and by diverse other arbitrary and illegal courses.

9. And whereas of late years, partial, corrupt, and unqualified persons have been returned and served on juries in trials, and particularly diverse jurors in trials for high treason, which were not freeholders.

10. And excessive bail hath been required of persons committed in criminal cases, to elude the benefit of the laws made for the liberty of the subjects.

11. And excessire fiues have been imposed; and illegal and cruel punishments intlicted. 
12. And several grants and promises made of fines and forfeitures before any conviction or judgment against the persons upon whom the same were to be levied.

All which are utterly and directly contrary to the known laws and statutes, and freedom of this realm.

And whereas the said late King James II having abdicated the government, and the throne being thereby vacant, his Highness, the Prince of Orange (whom it hath pleased Almighty God to make the glorious instrument of delivering this kingdom from popery and arbitrary power) did (by the advice of the Lords Spiritual and Temporal, and divers principal persons of the Commons) cause letters to be written to the Lords Spiritual and Temporal, being Protestants, and other letters to the several counties, cities, universities, boroughs, and cinque ports, for the choosing of such persons as represent them, as were of right to be sent to Parliament, to meet and sit at Westminster upon the two-and-twentieth day of January, in this year one thousand six hundred eighty and eight, in order to such an establishment, as that their religion, laws and liberties might not again be in danger of being subverted; upon which letters, elections have been accordingly made.

And thereupon the said Lords Spiritual and Temporal, and Commons, pursuant to their respective letters and elections, being now assembled in a full and free representation of this nation, taking into their most serious consideration the best means for attaining the ends aforesaid, do in the first place (as their ancestors in like case have usually done), for the vindicating and asserting their ancient rights and liberties, declare :-

1. That the pretended power of suspending of laws, or the execution of laws, by regal authority, without consent of parliament, is illegal.

2. That the pretended power of dispensing with laws, or the execution of laws by regal authority, as it hath been assumed and exercised of late, is illegal.

3. That the commission for erecting the late Court of Commissioners for Ecclesiastical causes, and all other commissions and courts of like nature, are illegal and pernicious.

4. That levying money for or to the use of the Crown, by pretence of prerogative, without grant of parliament, for longer time or in other manner than the same is or shall be granted, is illegal.

5. That it is the right of the subjects to petition the king, and all commitments and prosecutions for such petitioning are illegal. 
6. That the raising or keeping a standing army within the kingdom in time of peace, unless it be with consent of parliament, is against law.

7. That the subjects which are Protestants may have arms for their defence suitable to their conditions, and as allowed by law.

8. That election of members of parliament ought to be free.

9. That the freedom of speech, and debates of proceedings in parliament, ought not to be impeached or questioned in any court or place out of parliament.

10. That excessive bail ought not to be required, nor excessive fines imposed ; nor cruel and unusual punishments inflicted.

11. 'That jurors ought to be duly impanelled and returned, and jurors which pass upon men in trials for high treason ought to be freeholders.

12. That all grants and promises of fines and forfeitures of particular persons before conviction, are illegal and void.

13. And that for redress of all grievances and for the amending, strengthening, and preserving of the laws, parliament ought to be held frequently.

And they do claim, demand, and insist upon all and singular the premises, as their undoubted rights and liberties; and that no declarations, judgments, doings, or proceedings, to the prejudice of the people in any of the said premises, ought in any wise to be drawn hereafter into consequence or example.

To which demand of their rights they are particularly encouraged by the declaration of his Ilighness the l'rince of Orange, as being the only means for obtaining a full redress and remedy therein.

llaving therefore an entire confidence that his said llighness the l'rince of (1)range will perfect the deliveranee so far advanced by hin, and will still preserve them from the violation of their rights, which they have here asserted, and from all other attempts upon their religion, rights, and liberties;

If. The satid Lords spiritual and Temporal, and Commons, assembed at Westminster, do resolve, that William and Mary, P'rince and l'rincess of ()range, be, and be declared, King and gueen of England, Frauee, and Ireland, and the dominions theremnto belonging, to hold the Crown and royal dignity of the said Kingdoms and dominions to them the said l'rinee and P'rincess during their lives, and the life of the survivor of them; and that the sole and full "xereise of the regal power be only in, and executed by, the said Prince of (1range, in the names of the said prince and 
Princess, during their joint lives; and after their deceases, the said Crown and royal dignity of the said kingdoms and dominions to be to the heirs of the body of the said Princess; and for default of such issue to the Princess Anne of Denmark, and the heirs of her body; and for default of such issue to the heirs of the body of the said Prince of Orange. And the Lords Spiritual and Temporal, and Commons, do pray the said Prince and Princess to accept the same accordingly.

III. And that the oaths hereafter mentioned be taken by all persons of whom the oaths of allegiance and supremacy might be required by law, instead of them; and that the said oaths of allegiance and supremacy be abrogated.

I, A. B., do sincerely promise and swear, That I will be faithful and bear true allegiance to their Majesties King William and Queen Mary :

So HELP ME GoD.

I, A. B., do swear, That, I do from my heart abhor, detest, and abjure as impious and heretical, that damnable doctrine and position, that Princes excommunicated or deprived by the Pope, or any authority of the See of Rome, may be deposed or murdered by their subjects, or any other whatsoever. And I do declare, That no foreign prince, person, prelate, state, or potentate, hath, or ought to have, any jurisdiction, power, superiority, pre-eminence, or authority ecclesiastical or spiritual, within this realm:

So Help ME God.

IV. Upon which their said Majesties did accept the Crown and royal dignity of the kingdoms of England, France, and Ireland, and the dominions thereunto belonging, according to the resolution and desire of the said Lords and Commons contained in the said declaration.

V. And thereupon their Majesties were pleased, that the said Lords Spiritual and Temporal, and Commons, being the two Houses of Parliament, should continue to sit, and with their Majesties' royal concurrence make effectual provision for the settlement of the religion, laws, and liberties of this kingdom, so that the same for the future might not be in danger again of being subverted; to which the said Lords Spiritual and Temporal, and Commons, did agree and proceed to act accordingly.

VI. Now in pursuance of the premises, the said Lords Spiritual and Temporal, and Commons, in parliament assembled, for the ratifying, confirming, and establishing the said declaration, and 
the articles, clauses, matters, and things therein contained, by the force of a law made in due form by authority of parliament, do pray that it may be declared and enacted, That all and singular the rights and liberties asserted and claimed in the said declaration, are the true, ancient, and indubitable rights and liberties of the people of this kingdom, and so shall be esteemed, allowed, adjudged, deemed, and taken to be, and that all and every the particulars aforesaid shall be firmly and strictly holden and observed, as they are expressed in the said declaration; and all officers and ministers whatsoever shall serve their Majesties and their successors according to the same in all times to come.

VII. And the same Lords Spiritual and Temporal, and Commons, serionsly considering how it hath pleased Almighty God, in his marvellous providence, and mereiful goodness to this nation, to provide and preserve their said Majesties' royal persons most happily to reign over us upon the throne of their ancestors, for which they render unto llin from the bottom of their hearts their humblest thanks and praises, do truly, firmly, assuredly, and in the sincerity of their hearts, think, and do hereby recognize, ackunwedge, and declare, that King James II having abdicated the government and their Majesties having accepted the Crown and royal dignity aforesaid, their said Majesties did become, were, are, and of right ought to be, by the laws of this realm, our sovereign liege Lord and Lady, King and Queen of Fngland, France, and treland, and the dominions theremto belonging, in and to whose princely persons the royal state, Crown, and dignity of the same realms, with all honours, styles, titles, recalities, prerogatives, powers, jurisdictions and authorities to the same belonging and appertaining, are most fully, rightfully, and entirely invested and incorporated, uniterl, and amnexerl.

VIII. And for preventing all questions and divisions in this realm, by reason of any pretended titles to the Crown, and for proserving a certainty in the succession thereof, in and upon which the unity, peace, tranpuillity, and safety of this matim, doth. under Gol, wholly consist and depend, the satid torts spiritual and 'T'mjoral, and Commoss, do beserele their Majesties that it may be enacted, established, and declared, that the Crown and rewal gencroment of the said kingrloms and dominions, witl all and singular the premises theremuto belouging and appertaining. shall he aml continue to their said Majesties, and the survivor of them, dhring their lives, and the life of the survivor of them. And that the 
entire, perfeet, and full exercise of the regal power and government be only in, and executed by, his Majesty, in the names of both their Majesties during their joint lives; and after their deceases the said Crown and premises shall be and remain to the heirs of the body of her Majesty: and for default of such issue, to her Royal Highness the Princess Anne of Denmark, and the heirs of her body : and for default of such issne, to the heirs of the body of his said Majesty : and thereunto the said Lords Spiritual and Temporal, and Commons, do, in the name of all the people aforesaid, most humbly and faithfully submit themselves, their heirs and posterities, forever: and do faithfully promise, That they will stand to, maintain, and defend their said Majesties, and also the limitation and succession of the Crown herein speeified and contained, to the utmost of their powers, with their lives and estates, against all persons whatsoever that shall attempt anything to the contrary.

IX. And whereas it hath been found by experience, that it is inconsistent with the safety and welfare of this Protestant kingdom, to be governed by a Popish prince, or by any king or queen marrying a Papist, the said Lords Spiritual and Temporal, and Commons, do further pray that it may be enacted, That all and every person and persons that is, are or shall be reconeiled to, or shall hold communion with, the See or Chureh of Rome, or shall profess the Popish religion, or shall marry a Papist, shall be excluded and be forever incapable to inherit, possess, or enjoy the Crown and government of this realm, and Ireland, and the dominions thereunto belonging, or any part of the same, or to have, use, or exercise any regal power, authority, or jurisdiction within the same; and in all and every such case or cases, the people of these realms shall be and are hereby absolved of their allegiance; and the said Crown and government shall from time to time descend to, and be enjoyed by, such person or persons, being Protestants, as should have inherited and enjoyed the same, in case the said person or persons so reconciled, holding eommunion, or professing, or marrying as aforesaid, were naturally dead.

$\mathrm{x}$. And that every king and queen of this realm, who at any time hereafter shall come to and succeed in the Imperial Crown of this kingdom, shall, on the first day of the meeting of the first parliament, next after his or her coming to the Crown, sitting in his or her throne in the House of Peers, in the presence of the Lords and Commons therein assembled, or at his or her coronation, before such person or persons who shall administer the coronation 
oath to him or her, at the time of his or her taking the said oath (which shall first happen), make, subscribe, and audibly repeat the declaration mentioned in the statute made in the thirteenth year of the reign of King Charles II intituled 'An Act for the more effectual preserving the King's person and government, by disabling l'apists from sitting in either House of Parliament.' But if it shall happen, that such king or queen, npon his or her succession to the crown of this realm, shall be under the age of twelve years, then every such king or queen shall make, subseribe, and audibly repeat the said declaration at his or her coronation, or the first day of meeting of the first parliament as aforesaid, which shalt first happen after such king or queen shall have attained the said age of twelve years.

XI. All which their Majesties are contented and pleased shall be declared, enacted, and established by anthority of this present parliament, and shall stand, remain, and be the law of this realm forever; and the same are by their said Majesties, by and with the adviee and consent of the Lords Spiritual and Temporal, and Commons, in parliament assembled, and by the authority of the same, declared, enacted, or established accorlingly.

XIr. And be it further leclared and enacted by the anthority aforesaid, That from and after this present session of parliament, no clispensation by non obstente of or to any statute, or any part thereof, shall be allowed, but the same shall be held void and of no effect, except a dispensation be allowed of in such statute, and exrept in such cases as shall be specially provided for by one or more bill or bills, to be patsed during this present session of farliament.

XIII. I'rovided that no chater, or grant, or pardom granted before the three and twentioth day of october, in the year of our Iord one thousand six hundered dighty-nine, shall be any ways imperanderl or invalidated by this act, lnt that the same shall be and remain of the same forrere and effect in law, and no othere, than as if this act harl never leen mate, - Statutes of the Roalm, vi. $112-14 i$. 


\section{APPENDIX D.}

\section{A SUMMARY OF THE CONSTITUTION OF THE UNITED STATES.}

THE Constitution is in seven articles. The first article relates to the organization and powers of Congress, which consists of a Senate and House of Representatives. Representatives are to be inhabitants of the State for which they are chosen, to be twentyfive years old at least, and are to serve two years. Each House of Representatives thus lasts two years, and this period is usually known as a Congress: the fiftieth Congress expired March 4, 1889, having completed the first century of the Constitution. Representatives are assigned to States in proportion to the population, and this fact forced the provision for a decennial census, the first appearance of such a provision in modern national history. Besides the Representatives from the States, a few delegates from the Territories have seats in Congress, possessing the right to debate but not to vote. The House elects its Speaker and other officers, and has the power of impeachment.

The legislature of each State elects two Senators, to serve for six years ; and no State can be deprived of its equal share of representation, except by its own consent. The Senators are divided into three classes, the term of one class expiring every two years. Senators are to be at least thirty years old, and must be inhabitants of the States from which they are chosen, and citizens of the United States for at least nine years previous to their election. The VicePresident presides over the Senate, having no vote unless in case of an equal division.

All officers of the United States are open to impeachment by the House of Representatives, the impeachment to be tried by the Senate, and the penalty to be no more than removal, and disqualification to serve further under the United States. When the President is tried, the Chief Justice of the Supreme Court presides. 
The members of both Houses are privileged from arrest and from being questioned elsewhere for words spoken in debate. Each House passes on the election of its own members; but an Aet of Congress may control the Acts of the State Legislature as to time, place, and manner of elections, except as to the place of choosing Senators, in which the Legislature remains supreme. The two Houses cannot adjourn to another place, or for more than three days, unless by common consent. Their members are paid by the United States, and must not be office-holders or receive any office created or increased in pay during their term of service in Congress.

When a bill passes both Houses it goes to the President. If he signs it, it becomes law. If he holds it without signing for ten days (Sundays excepted) it becomes law, unless the final adjournment of Congress comes in the ten days. If the President decides to veto a bill he returns it, with a statement of his objections, to the House in which it originated. It can then only become law by the vote of two-thirds of both Houses.

The powers of Congress are: to lay and collect taxes, duties, imposts, and excises; to borrow money ; to regulate foreign and domestic commeree; to make rules for naturalization and bankruptcy laws; to coin money, regulate the value of foreign coins, and fix the standard of weights and measures; to punish the eounterfeiting of Federal securities and current coin ; to establish postoffices and post-roads; to establish patent and copyright systems; to establish courts inferior to the Supreme Court; to pminish offences on the high seas or against international law ; to deelare war, grant letters of marque and reprisal, and nake rules for eaptures; to raise and support armies, no appropriation to be for more than two years; to provide and maintain a navy; to make articles of war; to use the militia of the states in exeeuting Federal laws, suppressing insurretions ant repelling invasions; to provide for organizing, arming, ant diseiplining this militia, leaving the States to appoint the oflicers and earry ont the system; to establish a national eajutal or Fenteral distriet, and to exereise exchusive powers of legislation over it, and over sites for forts, dock.yaris, ete, bought hy purmission of the states; and finally, to make all laws whieh shall he necessary and proper for earrying into exeention the foregring powers, and all other powers vestent by this Constitution in the forrermuent of the Lnited states, or in any department or oflice thereof.

'The following prohibitions must also be noted: The Federal 
Government shall not suspend the privilege of the writ of habeas corpus except in case of rebellion or invasion, when the public safety requires it. Congress must not pass any bill of attainder or ex post facto law, tax exports, gire commercial preference to the ports of one State over those of another, lay direct taxes except in proportion to census population, or grant any title of nobility. Money is to be taken from the treasury only in consequence of appropriations made by law. And no person in the service of the United States may accept any gift or title from a foreign power without consent of Congress. The States are forbidden to make treaties, to grant letters of marque and reprisal, to coin money, to emit bills of credit, to make anything but silver a legal tender, to grant any title of nobility, to pass a bill of attainder, ex post facto law, or law impairing the obligation of contracts. They are forbidden (except by consent of Congress) to lay any duties on imports or exports, except inspection charges, to be paid into the Federal treasury; to lay any tonnage duties; to keep troops (a word which does not cover militia) or ships in peace; to make any agreement with another State or with a foreign power; or to engage in war unless actually invaded.

The President is to be a native citizen, at least thirty-five years old, and at least fourteen years a resident within the United States. $\mathrm{He}$ is paid by the United States; and his salary is not to be increased or diminished by Congress, during his term. He is sworn to execute his office faitlfully, and to preserve, protect, and defend the Constitution of the United States. In case of his death, resignation, or inability (by impeachment or otherwise), the VicePresident succeeds him; and in case of the inability of both, the members of the Cabinet succeed in a prescribed order (according to the Presidential Succession Act of 1886). The President has the veto power already described, sends messages to Congress on the state of the Union or on special subjects, convenes either House or both on extraordinary occasions, receives foreign envoys, commissions officers of the Lnited States, and oversees the execution of the laws passed by Congress. He makes treaties; but no treaty is valid unless passed by the Senate by a two-thirds vote of those present. He appoints ministers and consuls, judges, and all other officers whose appointment Congress has not vested in other officers; but presidential appointments must be confirmed by the Senate, though the President may make temporary appointments during the recess of the Senate, to hold until the end of their next 
session. He is commander-in-chief of the army and navy, and has power of pardon or reprieve for offences against Federal laws, except in case of impeachment. And he may call on each head of a department for an opinion in writing on any subject relating to his department. The last clause has evolved the Cabinet, a term not known in the Constitution. When Congress has by law organized a department, its leading officer is called its Secretary. There are now eight departments, - those of state, of the treasury, of war, of the navy, of the post-office, of the interior, of justice, and of agriculture. The Seeretaries are selected by the President and are confirmed by the Senate, but are not responsible to any one but the President. Nor is he bound by their individual opinions, or even by a unanimous opinion from one of their periodical meetings. They are his advisers only.

The people have no direct vote in the ehoice of President and Vice-President: they choose Electors, each State having as many Electors as it has Senators and Representatives together; and the Electors choose the President and Vice-President. The Electors are to be chosen in such manner as the Legislature of each state shall direct; and this plenary power of the Legislatures was the source of the unhappy disputed election of 1876-7. Lintil 1887 Congress refused to provide for necessary proof of the State's action, and clained the power to provide from time to time for emergencies. Now, provision is male by the klectoral comnt Aet of 1887 , for the State's certification of its votes; and the certificate which comes in legal form is not to be rejectoll but by a vote of both Ilouses. If there is no miajority of electoral sotes for l'resident, the llonse of Representatives chooses one from the three names lighest on the list, each state having une voth. The Electors were meant to exereise perfect frechom of choice, an intention at present completely frustrated.

The Constitution provides for one sulpeme Court, having original juriscliction in eases affecting foreign ministers and (onsuls, and tlose to which a state shall be a party, and alprellate juriselietion from such subordinate ('enrts as Comeress shall from time to time

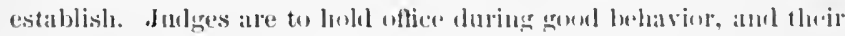

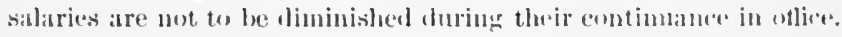
Federal courts deal with all cakes in law or chuity arising muler the Constitution, or the laws of treattics matule under it ; with all eatses affeeting public ministers and consuls, ar adniralty or maritime law; with suits by or against the Lnited states; atul with 
suits by one State against another, by a State against citizens of another State, by a citizen of one State against a citizen of another, by a citizen of a State against citizens of his own State when the question is one of a grant of land from different States, by a State or its citizens against foreigners, or by a foreigner against an American. The Supreme Court now consists of a Chief Justice and eight Associate Justices; below this there are nine Circuit Courts, each consisting of a Supreme Court Justice and a Circuit Judge; and fifty-six District Courts, each with a District Judge. Each Circuit comprises several States; and the Snpreme Court Justices, in addition to their Circuit work, meet in bank annually in Washington. The Districts cover each a State, or a part of a State. The Federal Courts are the principal agent in securing the power of the national government over individuals; and a most important agent in securing to the national government its supremacy over the States. A most important provision of the Constitution is the grant of jurisdiction to Federal Courts in cases involving the construction of the Constitution, or of laws or treaties made under it. It was not until 1816 that the right of the Federal Courts to exercise this power was clearly established, and the Constitution thus became what it professed to be, "the supreme law of the land."

The States are bound to give credit to the public records of other States, to accord citizenship to the eitizens of other States, to return criminals fleeing from other States, and to return "persons held to service or labor" under the laws of another State. The Federal government is to guarantee a republican form of government to each of the States, and to protect each of thein against invasion, or, on application of the Legislature or Governor, against domestic violence. The Constitution provides that it is to go into force as soon as nine of the thirteen States shall ratify it, and that any future amendment, when passed by two-thirds of both Houses, and ratificd by the Legislatnres or conventions of three-fourths of the States, shall become a part of the Constitution. By application of the Legislatures of two-thirds of the States, a new convention, like that which framed the Constitntion, may take the place of the two Houses of Congress in proposing amendments.

Ten amendments were adopted so soon after the ratification of the Constitution that they may fairly be considered a part of the original instrument. They were dne to a general desire for a "Bill of Rights." They state expressly the general principle 
already given, that the Federal government is restricted to granted powers, while those not mentioned are reserved "to the States respectively or to the people." Somewhat later came the XIth Amendment, affeeting the judicial power, and the XIIth affecting the Electoral College. By the XIIIth, XIVth, and XVth, adopted since the Civil War, slavery was swept away, national authority magnified against State assumption, and the right to vote secured to all citizens withont account "of race, color, or previous condition of servitude."

The Constitution was meant only as a scheme in outline, to be filled up afterwards and from time to time, by legislation. The idea is most plainly carried out in the Federal justiciary ; but it is visible in every department. It has carried the Constitution safely through a century which has radically altered every other civilized government. The members of the convention of $178 i$ showed their wisdom most plainly in not trying to do too much; if they had done more they would have done less.

\section{APPENDIX E.}

\section{SUMMARY OF THE CONSTITUTION OF C.INAIA.}

The Dominion of Canada consists of the seven federated l'rovinces, - Queber, Nova seotia, Now Brunswiek, Prince bolward's Island, Ontario, Manitolst, and British Columbia, together with vast unorganizal territories.

In accorlanes with the provisions of the British North American Art of 18tio, which regulates the constitutions of Canalal, the

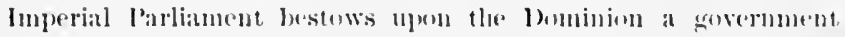

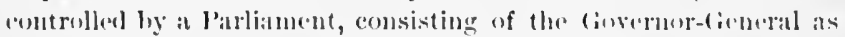
representative of the Queren of lingland, a sinatte, atul a llouse of

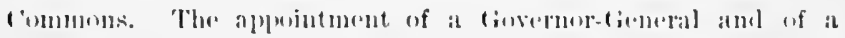
fommander-in-elhief of the military and niavil forese of canatil

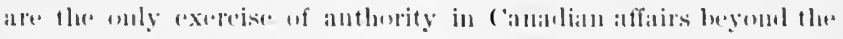
rontrol of the ('analian l'arliament; and the one remiluler left to show that the age of colenial tutelage is net motirely outgrown.

The senate comprises serenty-eight nembers. lach senatır 
must be at least thirty years old, a native-born or naturalized subject of Great Britain, and the possessor of property in his own Province to the value of $\$ 4000$, over and above his debts and liabilities. Appointment to the Senate rests nominally with the Crown, but virtually with the ministry of the Dominion; for under "responsible government," the premier pro tem. governs. Senatorial appointments are for life unless the appointee resigns, turns traitor, becomes bankrupt, or forswears allegiance to the Crown of England. 1

The number of members in the House of Commons is not fixed definitely, as in the membership of the Upper House, but varies with the returns of the decennial census. Quebec has sixty-five members in the Commons, and this number remains the same whatever may be the change of population in that Province; and the proportion this number of members bears to the number of the population of Quebec, after the census of that Province is taken, determines the members to be returned by the whole country; as each Province is entitled to send members to Parliament in the same ratio to its number of inhabitants that sixty-five bears to the population of the Province of Quebec. At present Quebec has a member for every 20,900 of her population; the other Provinces have members in the same proportion, except certain less populous Provinces that were specially excepted. The total number of Representatives at present is two hundred and ten. The roting for members of Parliament is by ballot, practically almost every owner or occupant of a house possessing the suffrage.

The Governor-General, like the constitutional sovereign he represents, keeps aloof from party in the state. He governs solely through his Ministers, who are his advisers; and so long as they have a majority of the people's Representatives at their back, he must hearken to their counsel. In this he has no choice. In the most extreme case, the utmost stretch of his authority only permits him to exercise the royal prerogative, dismiss his Ministers, dissolve the Parliament, and obtain a new expression of the will of the people. In a constitutional way, as advised by the Ministry, he speaks as with the voice of the nation; were he to speak otherwise, his words would have no authority. Each Minister of the Crown

1 The Senate of Canada, like the Upper Houses in general of the British Empire, is weak. A tendency prevails in the Empire to exchange the nominated for elective Upper Houses; sometimes the Upper House is dispensed with entirely. Dilke: Problems of Greater Britain, p. 505. 
is required to have a seat in Parliament; as the Lower House controls the finanee, the Ministers of the more important departments are generally members of that House, in order there fully to explain the operations of their departments.

The public business controlled by the Dominion goverument is transacted through thirteen departments, each of which is controlled by a member of the Ministry. 1. The Interior; 2 . Finance; 3. Public Works; 4. State; 5. Railways and Canals; 6 . Agrieulture; 7. Postal-service; 8. Justice; 9. Marine and Fisheries; 10. Customs; 11. Inland Revenue; 12. Militia and Defence; 13. That of President of the Council. The branches of public business coming under control of the Dominion government are : management of trade, commerce, indireet taxation, and the public debt; postal-service; the census and statisties ; militia and defence; payment of publie officers; lighthouses, navigation, shipping, and quarantine ; fisheries ; curreney, banking, coinage, and legal tender; weights and measures; bankruptey; patents and inventions; naturalization laws and laws of divoree; penitentiaries and criminal law ; railways, canals, and telegraphs, if extending beyond the limits of a single Province; and, in general, "such classes of subjects as are expressly excepted in the enumeration of the classes of subjeets, by this Aet exelusively assigned to the Legislatures of the Provinces."

A Lieutenant-Governor for each Province is appointed by the Dominion government. Each I'rovince, moreover, has a Legislature: in Ontario, Manitoba, and British Columbia, the Legislature consists of a single ehamber of Representatives, eleeted by a broad suffrage. The remaining Provinces have, besides the popular chamber, an Lpper lIouse: the Lpper IIouse, in the case of l'rinee Edward's Island, like the popular chamber, is eleetive; while in the case of Quebee, Nova Scotia, and New Brunswiek, it is noninated. Each l'rovince is left to itself to regulate such affairs as concern itself solely ; viz., the management of its public lands, the appointment of officers of justice, except judges (who are appointed by the lominion government); edueation; asylums, hospitisls, and charities; jails, prisons, and reformatories, except penitentiaries; municipal institutions; shop, tavern, and other license's; locil works; the solemnization of marriages; property and civil rights; administration of justice in provineial eourts, both of civil and erininal jurisdiction; the appuintment of magistrates and justionsof-the-peace; emisration so far as concerns provincial lands; and 
generally all matters of a merely local and private nature. No Province has the power to organize or maintain a military force; and the Dominion government has the power to disallow any enactments of the local Legislatures which are ultra rires. In each Province the Lieutenant-Governor has his Ministry, who cannot remain in office unless sustained by a majority of the Representatives of the people. The machinery of government is directly responsive to public opinion. Publicists, both English and American, have referred to the Canadian system as virtually one of the most democratic in existence.

It is interesting to note that as regards local government, there has been in Canada a complete revival of most ancient methods. In the local government of Ontario, called by Sir Charles Dilke the best in the world, an elected Reeve and four deputies make up each township council; and the Reeves, each with his four, from all the townships of a county, assembling, constitute together the Countycouncil, which thus reproduces the old shire-moot. In Quebec, also, the County-council is made up of the Mayors of the municipalities; but in Ontario and Manitoba the ancient name of Reeve is used. 1

The main difference between the Constitutions of Canada and the United States is that in Canada the central power is far stronger. The Dominion Parliament keeps in its own hands the criminal law and that of divorce, the appointment of judges, the nomination of the Lientenant-Governors of Provinces, the militia system, - all of which belong in the United States to the separate States. The Dominion has a veto, virtually exercised by the Prime Minister, though in the name of the Crown, upon the legislation of the Provinces. No such veto exists in the United States, if the local laws are constitutional.

Sir Henry Parkes, premier of New South Wales, is authority for the statement that the Constitution of Canada is to be the model for federated Australia. ${ }^{2}$ 


\section{INDEX.}

Adams, Brooks, in Atlantic Monthly, cited on the origin of the Constitution of the United States, 234.

Adams, Herbert B., in Jobns Hopkins Ilistorical and Political Traets, "The Germanic Origin of New England Towns," cited, $116,276$.

Adams, John, on the value of the New Fingland town-meeting, 284.

Adams, Samuel, life of, by the writer, quoted, on the "Coming on of the American Revolution," 199, etc.; on the American Tories, 227 , etc.; on the New England town-meeting, 278 , etc.

Addison, his "Remarks on Italy" quoted on the political competeney of the plain people, 334 .

fitheling, an Anglo-Saxon noble, 5.

Agitators, lower comeil of the army in $36 i t i, 1+1$.

"Agrcenent of the People," the tirst, liti, 141, ete. ; the second. 11:4!, 1.:', etc.

Alabana, local goversment in, 2ak.

Alfrel, King, his conservative instincts and intluenee, 21 .

Allen, W. F., on the government of Americall cities, 2 ?.y.

Ameriea, diseovered at a critical period for Anglo-saxon freedoun, 6.3 (soe United States).

Anlurry, his "Travels" rited on liatership of Massachusetts in American lievolution, 21li.

Anglo-sitxons, their primitive home aud condition, :2, etc.; their eonquest of Britain, 15, ete, ; their conversion to Christianity, 19; development of their polity, 20 , etc.; influence upon them of the Danes, 22, 23; their array at $\mathrm{H}$ iastings, 31 , 32; their prowess, 34 ; their overthrow by the Normans, 35.

Anglo-Saxon freedom, characteristies of, 4, ete.; why valuable, views of Jolm Stuart Mill and \&. Toulmin Smith, 12, ete.: its depression under Edward the Confessor, 23; its submergence at the Norman concuest, 35 ; to some extent restored through Magna Charta, 51 ; contended for by Wat Tyler and the peasants in the 14th century, 77; by Jack Cade and his followers in the 15 th century, 89 ; on the point of perishing umler 'ludor rule, 93 ; and under Stuart rule, 10:; thorouglily revived by the limleprendents in libti, 140, etr.; depuesserl once more at the Restorat im, 11:3; the American lievolution, an of fort for its vindication, 2:00; establisherl and formulated in the Constitution of the linited states, 2.32, etc.; its edncative power considered by Sir T. L. May, 2:i!; by J. Toulmin smith, :260; restorml to England and her deprendenejes siuce lieform litl of 15:20 and its successors, 2ti3, etc.; aldopted in part by lurope in genseral, 271; possilvility of its adoption in India, 2:2: to loe inlministercel only

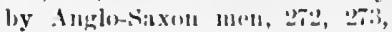
also : bor ; destinesl for the douninion of the worlu, : rots, ete; love 
for it of the plain people, 327, Battle Abbey, present appearance 328 ; of the high-placed and culti- of, 29 , etc.

vated, 328, etc.; connection with Bayne, Peter, his "Chief Actors of it of the high-placed and cultivated sometimes discreditable, 332 , etc. ; importance of a spirit of brotherhood among those inheriting it, 343 , etc.

Anne, Queen, crisis at her death, 173.

Arnold, Sir Edwin, on the identity of the English-speaking race, 317, 318.

Arnold, Matthew, on the identity of the English-speaking race, 314 ; on German “ Corporalişm," 331.

Australia, tirst accurately defined by Captain James Cook, 247; present condition of, 249 ; long used as a prison, 265 ; possesses responsible government, 266 ; its federation to be probably on the Canadian model, 266 (note); practically independent, 267 ; experience of, with large cities, 299 ; embarrassments of, from danger of Chinese encroachment, 322 .

Bacon, Lord, his "Essays" cited, on a narrowing of sympathies, 366.

Bagehot, his " English Constitution" cited, on changes in the temper of Parliament under the Tudors and Stuarts, 107; on the fusion of the executive and legislative powers in English government, 242 (note) ; on England as a "disguised republic," 256 (note).

Ball, John, his sermons to the peasants in the 14th century, 74 .

Bancroft, his "History of the United States" cited on causes of American Revolution, 198; on derivation of English Constitution from Anglo-Saxon sources, 213.

Bath, city of, as illustrating abuse of borongh representation in 18th century, 183. the Puritan Revolution" cited, 325 .

Belgium, partially adopts AngloSaxon freedom, 271 .

Bemis, E. W., in Johns Hopkins University Stndies, cited, 288, 289, 296.

Bewdley, as illustrating abuses of borough representation in 18 th century, 183.

Bil] of Rights, passed by Parliament, 1689, 167 ; full text of, Appendix C.

Birmingham, city of, unrepresented in 18 th century, 183 .

Black Death, of 1348 , its effect on economic condition of England, 72.

Blackstone, his "Commentaries" cited on Parliament's freedom from restraint, 233 .

Bluntschli, cited, on value of townmeeting, 283.

Board of Trade, its mistaken policy in 17 th and 18 th centuries, 199.

Borough, a more strictly organized township,18; character and polity of, in the Norman epoch, 45 ; insignificance of members for, in the early Parliaments, misfortunes of, 66 ; largeness of life much curtailed in 15 th century, 87 ; destruction of the franchise in, 181 ; "rotten boroughs," 182 ; their political degradation under George III, 183; improved condition of, at the present time, 261 .

Bright, John, on England and America as two nations, but one people, 344 .

Brotherhood of English-speaking men, views of J. R. Seeley, 343; of John Briglit, of Sir Henry Parkes, of Goldwin Smith, of Sir George Grey, 344; of J. C. Firth, 345 ; of the Westminster Reviero, reasons for its expediency, 346 ; 
as keeping vivid Anglo-Saxon traditions, 352 ; as seeuring Anglo-Saxon ascendency, 35t; as leading toward a brotherhood of the human raee, 365 , ete.

Browning, Osear, his " Modern England" eited on the Reform Bill of 1832,253 .

Brunswick, House of, of little mark, but pledged to constitutional rule, 173.

Bryee, James, his " American Commonwealth" eited, 235, 237, 264, 271, 279, 2918, 300, 315, 316, 332; in Johns Hopkins University Studies, 5th series, IX, 242.

Buekingham, as illustrating aluses of borough representation in $18 \mathrm{tl}_{1}$ century, 183.

Buekle, his "IIistory of Civilization in England" eited on England as saved by American resistance in American Revolution, 225, 231.

Burgesses, House of, in Virginia, 120 ; its inclependent temper, 125.

Burke, Edmund, on importance of preserving representative claracter of llouse of Commons, 1ss: his speeeh on the Stamp Act, 20s; his doctrine of representation, 211; his position as regarils America, 2e: believes Fugland saved by Ameriean resistance, 2w; opposes the radicals, 22:1; consistent in opposing French levolution, 2:3; laments the fall of the lourbons, 25.

Bute, shire of, as illustrating abuses of representation in 18 th century, $1 \times 5$.

Cabinet, origin and importanee of, in the linglislı polity, 17.t: its great modern signiticance, 25í.

Canden, 1ard, (hief Hustive of the common l'leas, his speech on the Stamp A.t, :mo: lis josition not that of the Colonies, 21:3: ealls Massachusetts the "ring-leading colony" in American Revolution, 216.

Canada, why it remained to England in Ameriean Revolution, 246; influenee there of exiled Ameriean Tories, 247; present condition of, 249; long neglect of, by the lome government, 2(is; becomes a federation with responsible government in 1867 , $26 t ;$; local self-govermment in, its practieal independence, $26 \%$ (and note); diffieulties before, 32:; summary of Constitution of, Appendix E.

Carlyle, his "Life and Letters of Cromwell" eited, 161.

Carnegie, his "Triumphant Democracy," 328.

Cass, Lewis, his influence in developing Michigan, $28 \mathrm{~s}$.

Catharine II, of Russia, has ideas of reform in 18 th century, 251.

Ceorls, their equality in primitivo Anglo-Saxon society, 3; analogous in condition to Anerican eitizen, 9 ; they sink into villeinage, 2:3.

Chamberlain, Mellen, eited, on the legral status of the Thirteen Colonies, 1:4; on causes of Ameriean Revolution, 2'1 lievolution as a strife, not of countries, lut of pirties, 220.

Clanpter llouse, at Westminster, tirst home of Parliament, 6 it.

Charles I, his arbitrary beginning, $107,10 \mathrm{~s}$; summons the Short and the lolig Parliament, 1640, 1:31; lifs slort-lived prulence, 1:3; elaraeter of lis party, 1:H, etc.; at Edgehill, 1:5; at Nischy, 1:ss; lis duplecity in the hamels of his enemies, 1:4:; , lenoun'ed in (iraml Army linmonstrunce, 14tis hisexecution, 1.51.

('harles 11, King in Sootland, 16it!, 155: restorel to Englisle throne, 1ivin, low: lowetits coming from lis bad charateter, 165. 
Charters, colonial, originally incorporations of trading companies, "perverted" into constitutions, 195,234 ; of medireval guilds, their relation to the Rigid Constitution, 234.

Chatham, Pitt, Earl of, his speech on the Stamp Act, 208; his position not that of the colonists, 213 ; strongly their friend, believes their cause that of the English Whigs, 221 ; thought English freedom was saved by the American Revolution, 222.

China, possible perils from, to Anglo-Saxon freedom, 354, etc.

Christian, commentator on Blackstone, cited, 232, 262.

Church, in early times protects the people, 49, 94, 95; under Henry VIII divorced from Rome and made Anglican, 95 ; its subserviency under Henry VIII, 96, 97; sanctions the jus divinum under the Stuarts, 104; its character under Laud, 108; its devotion to royalty at the Restoration, 163 ; at first sustains James II, 165; sides with the Tories, 170; hostile to Reform Bill of 1832, 254.

Chnreh, Alfred, his "Henry V", cited, 83.

Cities, their satisfactory administration in Fngland, 261; their size and multiplication in the United States, 299; difficulties of their government, 300,301 ; suggestions as to improvement of, 302 , etc.; ideas as to, of Hon. Seth Low, 302, etc.; grounds for a hopeful view, 304, etc.

Civil War, English, breaks out 1642, the parties, 134, 136.

Cobden, on a reformed upper House for Parliament, 261.

Coleridge, his early enthusiasm for free ideas, 251.

Colonial exhibition of 1886, scene at opening of, 269,270 ; as an illustration of the essential identity of Fnglish-speaking men, 318 , etc.

Colonies, the Thirteen, their establishment in America, 110, etc.; their condition in the middle of the 18th century, 192 , etc.; they claim to owe allegiance to King, not Parliament, but are not consistent, 196; the eeclesiastical grievance, 197 ; the commercial grievance, 198; their welfare sacrificed to English arlvantage, 200 ; assert through Franklin, in 176;; allegiance to King, but not Parliament, 202; donbt as to their constitutional position, 202,203 ; effect upon, of fall of Quebec, 203 ; exasperated by Grenville's policy, 204, etc.; their position not that of Pitt and Camlen, 213; superior in political wisdom to the mother-conntry, 214; influenced by a discreditable reason partly, united by the Stamp Act in resistance to England, 217; patriots in, embarrassed by the number of Tories, 225; become the United States with small constitntional change, 235 ; the new colonial empire managed on different principles, 246 ; how constituted, 246, etc., 264; Sir T. Erskine May on freedom of, $26 \mathrm{ss}$.

Comines, Philippe de, on English parliamentary government in 15 th century, 84.

Comitatus (see Gesith).

Commercial class, rises in importance, for the most part nonconformists, recruited by foreign immigrants, 171 ; tends to plutocracy, 175; its good influence as regards freedom, 198; its selfish treatment of the colonies, 199.

Commons, first represented in national council in 13 th century, 57 ; representation fully established under Edward I, 60. 
Commons, House of, definitely separated from House of Lords, 68 ; becomes the active and aggressive force of Parliament, 81; ceases to be fairly representative, 85 ; its character depressed by restriction of the franchise, 8i; preponderates over House of Lords under the Tudors, 98; gains in spirit under Elizabetls, 103 ; jourual of, cited, 150,154 ; abolishes kingship and House of lords, 1649, 164; its decline in character during 1sth century, 175 ; a majority of, returned by 1 irt; individuals, 186 ; people declare it not representative of them, 189; furnishes model for United States House of Representatives, 240; worst corruption of, in 1816; 25:; supremacy of, established in 1832 , becomes then truly representative, 255 ; its present omnipotence in English politics, 202 (sce also Parliament).

Commonwealth, English, its birth, career, and orerthrow, 15 , ete.

Congress, its resemblance to Parliament, 240, 241.

Connecticut, acreement of the towns Hartford, Wethersfield, and Windsor, its related to a Rigid Constitution. 2:34.

Constitution, Federal, of the United States, unipueness of the illea, 232 ; its value in at polity, 2:33; its origrin, 2\%: its provisions of English derivation, 2:5, 23:; the Presildent the King of the 18th ecutury, 2as; Electoral Creighton, M., his "Simon de MontCollege borrowed from Holy fort" quoted, 5s.

Roman Empire, 239; Congress Cromwell, Oliver, named "Ironfrom l'arlianent, 's10; supreme Court from linglish precelents, "4t: ahmiration for, of Sir 11. Maine, 24t; substantially unelangrel since 17s!, 27t; a similar one some day experlient for England, sti3; enthusiastio celebration of its centennial as in- dicating respect for it, 327,328 ; summary of, Appendix D.

Convocation, assembly of the Church, approves absolutism under James I, 104.

Cook, Captain Jannes, explores coasts of Australasia, 247.

Coote, H. C., his "Romans of Britain" cited, 16, 17 (note).

Coroner, eleeted in the shire-moot, 115.

Corruption, of Parliament, in 18th century, 177, ete.; in American cities, 300, etc.; Iilke's hopeful view as to its disappearance in English-speaking world, 307 (note).

Cortes, the national assembly of Spain, 62; orerthrown in 16 th century, 103.

Cotton and Payne, their " Euglish Colonization and Dependenec" quoted, 22:2.

County, unimportant in New England, 118; inportant in Virginia, its organization, 120 ; seene at conrt of, 121; important in Pennsylvania, 127; not changed at lievolutiou, : 2:ir (sec also Shire).

County Councils, established in Fngland in 1stis, signifieance of, 260.

Comnty system, of local self-government in Ameriea, 2-7; prevaled until Civil II atr generally in the South, get, ete.

Cowell, his "Interpreter" aulvocates jus dirinun under James cates.

sille" by l'rince Rupert at Marston Moor, at Nitseby, 1:ks; at tirst not in favor of popular governmont, 1tt; reconeiled with the army leoember, biti, 1tit lis prowess in litti, 14:; his lrish campaign, danger at llunbar, $15 i$; vietoriuus there and at Wor- 
cester, 158; becomes hostile to Edward II, deposed by Parliament, the Rump, 159; dissolves it, 1327,68 .

160; as l'rotector, 160; Milton's Edward III, growth of power of panegyric upon, 161.

Curia Regis, King's Court under the Norman and Angevin Sovereigns, 44.

Dakota, North and South, local government in, 294.

Danes, effect of their incursions, $22,23$.

Declaration of Rights, 1688, 166, 167.

Deerfield, Franklin Co., Mass., town-meeting at, 279 , etc:

De la Mare, Sir Peter, speaker of the Good Parliament, 69.

Democracy (see Plain People).

Denmark, partially adopts AngloSaxon freedom, 271.

De Tocqueville, on the Constitution, 232, 241; on value of New England town-meeting, 283, 284; on feebleness of French colonization, 288.

Dilke, Sir Charles, his " Problems of Greater Britain" cited, 266, $267,272,299,318,328$.

Dissenters (see Non-conformists).

Dobell, Sidney, his Sonnets quoted, 350 .

Domesday Book, description of, 40, 41.

Dunbar, Cromwell's victory at, 158.

East India Company, chartered 1600 , beginuing of British dominion in India, 111.

Eaton, Dorman B., cited, 188.

Edgehill, battle of, 1642, 137 .

Edinburgh, restriction of the franchise in 18th century, 184 .

Edward the Confessor, decay under him of the Anglo-Saxon polity, 23.

Edward I, importance of his influence, 59 ; his character, 60 ; great. development under him of representative government, 61 . Parliament under, 69.

Edward IV, decay of power of Parliament under, 92.

Elbe, country near mouth of, the primitive Anglo-Saxon home, described, 2.

Electoral College, borrowed from Holy Roman Empire for Federal Constitution, a failure in practice, 239.

Eliot, President, of Harvard, on the success of democracy, 336 , etc.

Elizabeth, accedes, 1558, rising temper of Parliament under, 99; her character and rule, 100 ; effect of her popularity, 102.

Emerson, Ralph Waldo, on the value of the New England townmeeting, 284.

England, its germ in the ancient Teutonic communities, 10; its unbroken development to the present day, 15 ; its fitness for representative government in 1265,54 , 55 ; freedom preserved to it by American Revolution, 222; its masses pro-American in American Revolution, 224; its greatness apparently destroyed by loss of the Thirteen Colonies, 245; acquires at once a new colonial empire, 246 ; much sympathy in, at first, for the French Revolution, 251 ; reaction from this, 252 ; becomes in modern times practically a republic, 263 ; present embarrassments of, from the Irish question, 322 , 323 ; love in, for Anglo-Saxon freedom, 328 .

Earl, Anglo-Saxon noble, 5.

Farmers, rise of class of, in 14th century, 71.

Feudalism, rise of, among the Saxons, 22, 23; its Frankislı and Norman development, 39 ; estab- 
lishment of the latter in England, 40; in full sway under Stephen, 43.

Filmer, Sir Robert, his absolutist theories, 164.

Firth, J. C., of New Zealand, on a coming brotherhood of Englishspeaking men, 345 ; on the Chinese, 355 , 356 .

Folk-moot (see Moot).

Forteseue, Sir John, on Lancastrian England, 84, 179.

Fox, Charles James, believes Eng- Free-laborers, rise of class of, 72 .

lish freedom preserved by Amer- Friends of the People, democratic ican Revolution, 222; eulogizes Montgomery, Ameriean general killed at Quebec, 224; favors parliamentary reform, 250 ; favors self-goverument in colonies, 264.

France, dying out in, of popular freedom, 168; saves cause of the colonies in Ameriean lievolution, 226; contrast between her constitution-makers and those of America, 23; ; rejoices in apparent downfall of England in American Revolution, 245; excesses of Revolution in, arrest the progress of reform in England, 250, 251; partially adopts Anglo-Saxon freelom, 271; instability of her freedom, 25.3 .

Franchise, right of, lield by the ceorls, 5; interfered with by incipiont foulalism, 2,; possessed as to focil matters by the peoplo, mulin r the Norman Kings, 52; possesserl by the yeometr as to diction of knights-of-the-shire, (fis: greatly restrictinl in 14:? 86,87 ; people try to vinclicate it numler Jack Cale, !n); broad franchise proposerl by the English Commonwealth, 15is: cansess of its great linitation in the shires after 1tiks, 17!, 1:4): in the loronghs, 1s1, 1s: ; A. Blaml, of Virginia, on, in Great Britain, 213: its educative effect after 15:\%,
255 ; its extension in England at present, 258.

Franklin, Benjamin, at the bar of the House of Commons in $176 t$, 202.

Franks, their origin and polity, 3s, 39.

Frederick II (Hohenstanfen), institutes in Italy popular assemblies, 62.

Freedom (see Anglo-Saxon Freedom). society at end of the 18 th century, 250.

Freeman, E. A., cited, 2, 7, 9, 10,53, $86,116,118,11 !), 25 \%$.

Froissart, his "Clironicles" on the Peasant Rebellion in the 15th century, it.

Fromle, on benefit to indivicluals from unification of nations, 368 .

Galloway, an American Tory, testifies in Honse of Commons as to strength of his pitrty, 22ti.

Galpin, S. A., in Walker's Statistical Atlas, cited, 2iti.

Gardiner, S. R., eiterl, \$8, 133, 1:38, $15 i 2,15 \%$

Georec 11l, his education and character, "2ls, 21!) ; his embarrassments in dealing with the Thirteen Colunies, 2.21, ete.

Georye, llenry, on deaty of the mediaval yeomen, 1:5: his selieme of lamb-holding a revival of the primitive teumre, 2yize.

(iermany. its partial adoption of Anglo-sison freedom, 271; its present groatuess dne rather to its rulers than its perple, isin, 331 .

fiesith, retinue of the leretega, 7 ;

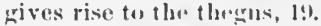

dilalstone, eomordes io Aurrion the primary among binglish-sjuaking lands, 312; on jeislency and fear of liberty at Oxfort University, 
333 ; on coming greatness of England and Russia, 357.

Glasgow, restriction of franchise in, in 18th century, 184.

Gneist, Rudolph, his constitutional history cited, 2, 96, 162 .

Godwin, William, his "History of the Commonwealth" cited, 144.

Goethe, on a narrow national feeling, 365 .

Gordon, his "History of the Independence of the United States," on a New England town-meeting, $117,118$.

Grace, ex-mayor of New York, on municipal government, 302 .

Graud Remonstrance, of the Loug Parliament, November, 1641, 133.

Grand Army Remonstrance, 1647, 147 , etc.

Greeks, jgnoralit of representation, 7.

Green, Jolın Richard, his " History of the English People," "Short History of the English People," and " Making of England," cited, $3,16,68,70,75,79,81,97,105$, 178, $189,309$.

Green, Thomas Hill, his "Works" quoted on the results of the English Commonwealth, 162.

Grenville, George, enforces revenue laws in the Thirteen Colonies, 204; believes the American cause anti-Whig, 222.

Grey, Earl, supporter of the Reform Bill of 1532, 254.

Grey, Sir Gcorge, on a league of the English-speaking race, 344 .

Guizot, his "History of the English Revolution," cited, 145 ; on necessity to existence of the United States, of preserving English traditions, 324 .

Hallam, his " Middle Ages " cited, 7; his "Constitutional History" cited, 164.

Hammond, Dr. W. G., denies presence of representation in early
Anglo-Saxon polity, 6 (note); on the value of a ligid Coustitution, 233.

Hampden, John, parliamentary leader in 1640, 131; his popularity, his views, his death, 137.

Harold, his accession, 24; his embarrassments at Hastings, 28; his appearance and character, 31 ; his death, 35.

Hastings, present appearance of battle-field of, importance of the battle, 25.

Henrietta Maria, Queen of Charles I, 132.

Henry I, character of his rule, 43.

Henry II, puts down feudalism, 43; establishes the jury-system in England, 44, 45.

Henry III, confirms Magna Charta, 50 ; defeated at Iewes by Simon de Montfort, 57.

Henry IV, power of Parliament at time of his accession, 81 .

Henry $\mathrm{V}$, his popular and heroic qualities, 82; his democratic spirit, 83.

Henry VI, growth of idea of jus divinum uuder, 86.

Henry VII, weakness of the nobility under, 94.

Henry VIIl, great increase of royal power under, 94 ; strikes down the Clurch, 95 ; his character and influence, 96 , etc.

Heretoga, the primitive army-leader, 7 .

High Commissiou, Court of, its establishment and character, 101, 102 ; its activity under the Stuarts, 106.

Holland, its ocean-war with the Commonwealth, 158; an oligarchy at end of 17th century, 16s; partially adopts Anglo-Saxon institutions, 271 .

Howard, George E., his "Introdnetion to the Local Constitutional History of the United States" 
cited, $3,9,113,116,119,120,126$, $127,286,290,294,296,297$.

Juguenots, their number in England after the Revocation of the Edict of Nautes, 172.

Hundred, the division between the tun and the seire, 6 .

Hungary, partially adopts AngloSaxon institutions, 271 .

Hutchinson, Thomas, his "History of Massachusetts Bay" cited, 216.

Illinois, local government in, 290 , etc.

Immigration, in Bryce's view so far not injurious to the United States, 316; danger to be apprehentled from, in the future, 324 , 325.

Imperial Federation, a popular irlea in British Empire, 343.

ludeuted servant, analogous to the lat, ?; condition of, in early Virginia, 123.

Independents, their rise and prineiples, 139 ; seize the power in England in 1648, 147; illeas of the party, 154; difticulties in their way, 155 ; establish a Council of State, 15ij; make war ayainst Ireland, Scotland, and Hollaul. 157, 15x: disseusions amoug them in $165 \% 3,15 \%$.

Inllia, character of English fominion in, 24s; village-ommunities of, as showing a capacity for self-covernment, 271 ; a native administ ration for, antivipated, :2::.

Inliana, local government in, 2ra:.

Internationul hivier, on municipal goverument, 302 .

International tribunal, sngrestiol by Sir Elwin Arnole, 318.

lowa, local govermment in, 28it, 'my.

Ireton, army-leader in English ('ivil War, 139; at first not in favor of popular government. 14 ; reeonciled at army prayer. meeting, December, 1647, 145; prepares Grand Army Remonstrance, 147 ; prepares other army manifestoes, 150 ; prepares the second Agreement of the People, 152.

Irisl, sustain American cause in American Revolution, 226; heary immigration into Ameriea, 277 , 278; England embarrassed by question concerning, 322,323 ; embarrassment to America from, 352.

Ironsides, name given Cromwell and his troopers at Marston Moor, by Prince Rupert, 138; advocate popular goverument, 140 ; their manifestoes, 143, etc.; win their chiofs to their side, their prayer-meeting, 145 ; their prowess in 1648, 147; in Ireland, 157 ; at Dunbar and Worcester, 158.

ltaly, death of freedom in, 168 ; partially adopts in modern times Anglo-Saxon freedom, 271 .

Jack Cade, justice and dignity of his cause in 15 th century, 8!), etc. James I, his antocratic ideas, 105. James 11, his accession, his evil policy, and good effect of it, 16ii, liti.

Iamestown, settled, 1607, charactor of the settlement, 111 .

Iefferson, Thomas, on the value of the New England town-meeting, ats.

dohn, aceession of, 4ti; Magna C'harta extorted from, 47; his insincerity aml doatl, 50.

Johns llopkins l niversity, llistori('1l and Pulitical Tracts of, cited, $3, \mathrm{~s}, ! 1,115,116,27 \mathrm{~s}$.

Josplith of Austria, favors reform, 2sl.

Jury, trial by, established in kingland loy llanry $11,4.5$.

Jus dirinm, not plaimed ly Norman Kings, t2; illeas gains strongth in $15 t h$ century, \&is; be- 
comes portentous under the Lecky, W. II., his "History of the Stuarts, 104; revives after overthrow of Commonwealth, 163, 164 ; falls out of favor in middle of 18th century, 177 ; in vogue once more under George III, 218. 18th Century " eited, 171, 180, 190, $194,211,212,214,216,2 \% 2,223$, $225,226,227,231,284,288,333$.

Lee, Richard Henry, his admiration of New England, 284.

Leeds, misrepresented in the 18th century, 183.

Kansas, local government in, 287, 293.

Kenilworth, home of Simon de Montfort, 55, 56 .

Kentueky, interested in the public schools since the Civil War, 296.

King, appears in Anglo-Saxon polity, how evolved, 18; partly hereditary and partly eleetive, 19; how modified by the Normans, 42; power of, depressed nnder Henry IV, 81; power of, nearly doubled under Henry VII, 93 ; still further ịcreased under Henry VIII, 94; absolutism claimed for, by the Stuarts, 105; swept away by the Rump, 1649, 154; restored under Charles II, 165 ; holds title to the colonies, 195; inconsistency of, as regards the colonies, 196; in " responsible government" becomes powerless, 257.

Knights-of-the-shire, appear in Parliament of 1265,57 ; the champions of the Commons, 64; elected in part by yeomen, 179; in 18th century still the best part of the House of Commons, 180.

Legislatures, disposition in the United States at present to distrust, 275 .

Leslie, David, nearly defeats Cromwell in eampaign of Duubar, 157.

Lessing, G. E., on a narrow national feeling, 365 .

Liberal party, rise of, in England in 18 th century, 190.

Lieber, Dr. Francis, on representation, 53.

Locke, John, lis seheme of a captain-general for the colonies, 199 .

Long Parliament (see Parliament).

Iords, House of, definitely separated from House of Commons, 68; its weakness under Henry VII, 94 ; impotence under Henry VIII, 96 ; swept away by the Commonwealth, 1649, 154 ; power of, over the Commons in 18 th century, 175,185 ; analogy between, and the United States Senate, 240, 241 ; opposes Reform Bill of 1832, 254; threatened with abolition, 255; its modern impotence, 258 (see also Parliament).

Louisiana, its retention of Freneh forms when admitted to the Union, 237 .

Lrts, a class below the ceorls, Low, Hon. Seth, on need for Eng3 ; analogous to Indians and in- land of a Rigid Constitution, dented servants, 9 .

Langton, Stephen, Archbishop of Canterbury, his importance in securing Magna Charta, 49.

Latimer, Bishop Hugh, his aecount of his yeoman father, 134 .

Jaud, William, Archbishop of Canterbury, instrument of Charles $I$, in attempt to seeure absolutism, 108; his fall, 132. 263 ; on municipal government, 302 , ete.

Lowell, James Russell, on constitutional restraints, 233 ; on value, to the Cnited States of preserving English traditions, 324.

Macaulay, Mr., English Radical writer, condemns Burke, 223.

Macaulay, T. B., his "History of 
England" eited, 15, 62, 100, 164, $166,169,178,183$.

Magna Charta, extorted from King John, 4i ; summary of, 48,49 ; its frequent confirmations, appearance of the copy of, in British Mnsenm, 50; full text of, Appen$\operatorname{dix} A$; its relation to the idea of a Rigid Constitution, 234.

Maine, Sir Henry, his "Ancient Village Communities" cited, 8, 27 ; lis " Popular Government" cited, 21; derives United States Constitution mainly from English preeedents, $234,238,240,241$, 242,243 ; his admiration for Federal Constitntion, 244, 262.

Manchester, unrepresented in 18 th century, 183.

Manor, Norman name for tunscipe, 44.

Mansfielı, Lord, chief-justice of England, his speech on the Stamp' Act, 209.

SIark, the primitive 'lentonic village, 3.

Marston Moor, battle of, 138.

Mary Stuart (Queen of Scots), as a promoter of Anglo-Saxon free(lom, ! : ).

Mary 'Tulor (Bloody Mary), gool effeet of her misrule in arousing linglame !s, !n.

Mary, Quewn of IIilliam III, acerdes, 11\%.

Marylaul, its early polity, 125; in the 1sth century, 1!t.

Massatiusetts, settleyl, 116; polity allopted, 117, 1!2: : ecolesiastio:al in before American licvolution, $1 ! 17$; lealler in the American lipvolution, 2lli (note).

Massey, his "llistory of the Reign of tieorge IlI" "itud, 231). "2it.

Mamlint, his "Short View of the Nabols, rich adventurers in 1sth New lingland Culonies" riterl, "2li (not: $)$.

May, Sir T. Erskine (Iorl Farn- Naseby, battle of. 1:2s. burough), in Eneyeloperlia Brit- Sution (The New lonk), wn Inu-

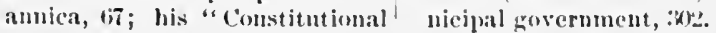

History of England" cited, 181, $183,185,187,259,263,268,283$.

Michigan, loeal government in, 287 , etc.

Middlesex electors, mass meetings of, over case of Wilkes, 189.

Mill, Jolun Stuart, on educative power of representative government, 12, 13, 283.

Milton, John, his panegyric on Cromwell, 161.

Minnesota, local government in, 294.

Mir, the Slavic village community, 7 ; popular govermment in, 63 , 358.

Missouri, local government in, 287 , 293 ; does not appreciate the township, 294.

Monasteries, dissolution of, under Henry VIII, !6.

Montesquieu, influence of " Esprit des Lois" on Constitutionmakers of the Lnited States, $242,256,257$.

Moot, assembly of the people, its place of meeting in primitive times, its functions, 5; of the tun analogous to the New Vinglaud town-meeting. 9; it persists umler incipient fumlalism, 24; of the shire combines with the Curice lirgis, 44 ; primordial cell of Anglo-Sixon freclom, its eondition in early America, 127, etr.; its present conlition in Ameriea, 25i5, ete.

More, Sir 'Thonas, testifies as fo the decay of the yeomanry, 1:3.

Morley, Jolun, his "life of Cobden" eited, 26il.

Iotley, .J. Lothrop, his faith in democracy, 335, 33*i.

century, their intluence in l'arliaminus, istis.$$
\text { nicipal zovormment, .ktz. }
$$ 
Navigation Laws, of 17 th, and 18th centuries, oppress the colonies, 199.

Nebraska, local government iu, $290,293$.

Newcastle, Duke of, his connection with parliamentary corruption in 18th century, 188.

New England, settlement of, 112 ; its character changed by foreign immigration, 277 (see also Massachusetts).

New Model, reconstituted army of the English Commonwealth, 138.

New Shoreham, illustrates political corruption of 18th century, 184 .

Newspapers, the great, established in middle of 18 th century, their good influence, 189.

New York, its early polity, 126; its condition in 18th century, 193; position and temper of, at outset of American Revolution, 215; difficulties of government in city of, 300 .

New Zealand, mapped out by Captain Cook, 247; present condition of, 249.

New Zealand Herald, The, on an English-speaking brotherhood, 348.

Non-conformists, their services to freedom, 162; all Whigs, the commercial class identified with, largely recruited by immigrant refugees from Catholic lands, 171; their pro-American sympathies, 224.

Non-resistance, to arbitrariness of kings, favorite theme of the clergy in time of Charles II and James II, 164.

Normandy, importance to England of loss of, 46 .

Normans, they land at Hastings, 27 ; their battle array, 32 ; their danger, 34; their origin and character, 38,39 .

North, Iord, on embarrassment from pro-American feeling in
England in American Revolution, 222.

North Carolina, local government in, since Civil War, 297.

Norway, adopts Anglo-Saxon institutions, 271.

Odo, Bishop of Bayeux, at Hastings, 34 .

Ohio, early constitution of, 286; of its local government, 293 .

Old Sarum, as illustration of corruption in borough representation, 183.

Opposition, function of the, in Responsible Government, 258.

Ordinances, royal, regarded under Stuarts as superseding legislation, 106.

O'Reilly, John Boyle, his poem at Plymouth, Aug. 1, 1889, quoted, 112,369 .

Oxford, illustrates political corruption of 18 th century, 184.

Parish, rises in importance, 113, 114 ; its form when transplanted to Virginia, 119; unchanged in American Revolution, 237.

Parkes, Sir Henry, on an Englishspeaking fraternity, 344 ; on the superiority of the Chinese, 355 .

Parliament of 1265,57 ; of 1295,60 ; how related to the witenagemote, 63; how constituted under Edward I, 64; division into two Houses in 1341, 68; good Parliament of 1376,69 ; its hostility to the peasants in 1380,79 ; deposes Richard II and elects Henry IV, its great power under Henry IV, its aristocratic temper, 81 ; reactionary in spirit in middle of 15th century, 85, etc.; shrinks into an oligarchy, 88; loses power under the Tudors, 98 ; described by Sir Thomas Smith, 100; its spirit rises under the Stuarts, 107; Short and Long, 131; passes Grand Remonstrance, November, 1641, ar- 
rest of the Five Members resisted Pitt, the elder (see Chatham).

by, 133; at war with the King, Pitt, William (the younger), de1642,136 ; negotiates a peace with Charles I, 1648, 149; purged by Pride and becomes the Rump, 150 ; ideas of the Rump, 150 , ete. ; dissolved by Cromwell, 1653, 160; subserviency of, under Charles II, 16t; passes the Bill of Rights, 1689,167 ; recognized as supreme in 18 th century, 173 ; its corruption, 177 . ete. ; its arbitrary assumption in the case of Wilkes, 189 ; assumes jurisdiction over eolonies, 197 ; agitation for reform in, begins with the Wilkes troubles, 223; furnishes a model for the Congress of the Cniter States, 240, 241 ; bottom of abuse reached in 1816, 252; reformed in 1832,255 ; its working under Responsible Government, 257, 258 (see also Lords and Commons). nounces the war against Ameriea, 225 ; introluces the question of parliamentary reform in 1782 , 250 ; leads aristocratic England against revolutionary France, 252; initiates colonial self-goverument, 264.

Plain people, their love for AngloSaxon freedom, 327, 328; their political competeney, view of $J$. Toulmin Smith, 3\&); of Bryce, 332; of Lecky, 333; of Addison, 334 ; of Motley, 335 , 336; of President Eliot of Harvard, 337, ete.

Plantagenets, their masterful qualities, 105.

l'ymouth, settled, 1620, character of the settlers, 112; the method of settlement at, deseribed, 115.

Pombal, in Portugal, favors reforms, 251.

Patriotism, when narrow, a mere expinsion of selfishuess, 201; view of Lessing, of Goethe, 365; a narrow patriotisin condemned, 3 itik, ete.

Peasants, rebellion of, in 1380 , under Wat Tyler, 75, etc.; under Jack Cade, in 1450, 89, etc.

Pelh:m, prime minister, 1745-1754, honest himself, but stoops to bribery, 178.

Penusy'lvania, early polity of, 126 : in 18 th century, 194; temper of, at outset of American Revolutiou, 215.

Petition of Kight, 1628, 107; text of, Appenulix $\mathrm{H}$.

Petty, Sir Willian, his "Political A rithmetic" quoterl, 171.

Phelau, his "History of Tennessee" quoterl, 1:2.?

Phillips, his " (ieschichte les AngelSächsischen Rechts" quotrul, 3.

P'ietoll, J. Allanson, on loral sclfgovernment in Ameria, $34 ;, ; \%$.

l'ilgrims of Plymouth revert in lyme, solm, parliamentary lealer their polity to old ways, 113.

Poor whites, origin of, in the South, 123.

Portugal partially adopts AngloSaxon freedom, 271.

Presbyterians, as a party in the English Civil War, 130; oppose Independents in the field, $1 \mathrm{Hi}$.

Presidlent of the Inited States, his likeness to English King of $18 \mathrm{th}$ century, 2:38.

Preston, battle of, in $1648,147$.

l'retender, his doubtful birth and character, 173 .

l'rice, 1)r. Richard, leading non-eonformist, his pro-Americal sympathies, 2at.

Proctor, K. A., on illentity of the two branches of the Finglishspeaking race, $314,315$.

Public opinion make's itself folt first in midcllo of 1sth century, 1k!! its great power at presion, 2.5.1.

Publication of parliamentary debites, sahutary intluence from, [k9.

in English Civil War, 131; his 
great authority, 136 ; his views, his death, 137 .

Quakers embarrass the patriots in American Revolution, 226.

Quarter Sessions, Court of, rise of, under Edward III, 82; supersedes in part the shire-moot, 114 ; transplanted to Virginia, 120 ; continues to administer the county in Virginia and the South, 193, 237.

Quebec, effect of the fall, in 1759, upon the Thirteen Colonies, 203.

Ramsay, his "History of the American Revolution" cited, 226.

Ransome, his "Rise of Constitutional Government in England" cited, 104, 182.

Reform Bill of 1832, first introduced, March, 1831, its provisions, 253; its second introduction, 254; its passage and happy results, $25 \overline{5}$; supplemented in 1867 and 1884, 256.

Reformation helps in England the power of the Crown, 96.

Reign of 'Terror in France, reaction from excesses of, 251.

Representation in politics an AngloSaxou idea, 9; first appears as regards the national council in 1213,46 ; its vitality in the early shire-moot, 52 ; its value, conditions necessary for its successful practice, 53,54 ; those conditions satisfied in England, 55; appears in Parliament of 1265,57 ; confirmed under Fdward I, 60; in Spain, Germany, Italy, and France, 62 ; a burden rather than a privilege at first, 65 ; its character in New Eugland, 128; its decay in England in 18 th century, 175; degeneracy of, in the English shires, 178, ctc.; power over, of the nobles and the rich, 180 ; of 'Thirteen Colonies, Chatham's view of, 208; Camden's and Mansfield's, 209; Burke's,
Yorge's, and Lecky's, 211; Richard Bland of Virginia on, iu Great Britain, 213; fairly secured to the English nation in 1832, 255. Representatives, House of, of United States, modelled on English House of Commons, 240.

Responsible Government, its origiu, 174 ; description of, 257 , 258 ; bestowed upon the new colonial empire, 266.

Restoration, reaction from ideas of the Commonwealth at, 163.

Revolution of 1688, momentous character of the crisis, 167 , etc. ; merely a restoring of the old system, 169; its partial character, 174.

Revolution, American, how it came on, 192 , etc. ; a struggle of parties, not.countries, 218 , etc. ; supported by a strong minority in Parliament, by a large party outside, 221.

Revolution, French, excesses of, arrest progress in England, 250, 251.

Rhode Island, agreement of settlers in 1637 a germ of the Constitution, 234.

Richard I, his bad rule, 46 .

Richard II, his bearing before the rebellious peasants, 75 ; his portrait in Westminster Abbey, 76 ; at Wat Tyler's death, 77; his treachery, 78 ; his absolutism and deposition, 80.

Richard III, his accession, 92.

Richmond, Duke of, pro-American in American Revolution, 224.

Rivington, his "Independence the Object of Congress in America" cited, 216.

Robiuson, John, pastor of the Pilgrim Fathers, 112.

Rogers, J. Thorold, his "History of Agriculture and Prices" cited, 65,77 .

Roman de Rou, Norman poem on the Conquest, $30,31,33$. 
Romilly, Sir Samuel, on political Separatists, sect of the Pilgrim corruption in his time, 187 .

Rousseau, his wide influence, 251.

Kump (see Parliament).

Runnymede, as seen from Windsor Castle, 47.

Rupert, Prince, at Edgehill, 137; at Marston Moor and Naseby, 138.

Rushworth, his " Historical Collections" cited, $142,147$.

Russell, Lord John, introduces the Reform Bill in 1831, 253.

Russia, her great future predicted by Gladstone, 357; sketch of her empire, of luer people and institutions, 358; of her history, 35!); characteristics of the present rlespotism, 360; her vast power, 361 ; as a rival of Auglo-Saxondom, 362 , ete.

Kyley, Gulielmus, his "Placita Parliamentaria" cited, 6 .

Sabine, Jorenzo, his "American Ioyalists" cited, $2 * 27$.

Salisbury, illustrates abuses of representation in the 18 th century, 183.

Suturdty Reriev, The, Iondon, on Strafford and his policy, 275.

Scoteh, Vane negotiates Solem League and Covenant with, 1:35; defeated by C'romwell at l'reston, lits, 117; crown Charles 11, in 164!), and make war on English Commonwealth, 15\% ; defeaterl at 1unbar and Worcester, J5,4; immigrants larincly Tory in Ameri-

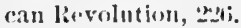

Seeliy, J. li., his "kxpatusion of kuerland" rited, on lealership of New kinglanel in Ameriean Raver lntion, zlli (note); on Imperial Folloration, iifis.

Self-Jenying Urdiname, of limb, $1:$ ins.

Scritte, of thu liniterl Stites, anal. ory lwetwern, and the llowse of lorik, 210); a fortumate (reation of the Constitution-makers, '2.1.

Fathers, 112.

Shaw, Albert, on local government in lllinois, in Johns Hopkins University Studies, eited, 2:0.

Ship-money, an illegal exaction under Charles I, 10?.

Shire, its character in primitive times, 18 ; misfortumes to representations in, 180 (see also Moot).

Simon de Montfort, his origin, 54 ; convenes the Parliament of 1265 , 57 ; his death and influenee, 58.

Slav (see Russia).

Slavery, reasons for its development in Virginia, 123.

Smith, Adam, his " Wealth of Nations" cited, 199; favors setting free the Thirteen Colonies, 222.2.

Smith, Goldwin, on a moral union of the Anglo-Saxon race, 344 .

Smith, J. Toulmin, his "Local SelfGoverument anil Centralization" cited, 3, 14, 53, 54, 283, 324), 330 .

Social compact on boarl the " Mayflower," its relation to a Rigid Constitution, 2:3t.

Solemu Leagne and Covenant, negotiated hy Vane with the seoteh, $164: 3,13 \mathrm{~s}$.

South, in United States, Virginia leader and typical colony of, 111, gus; change of spirit in, since the Civil War, :2:k5.

South Africa, becomes an Jinglish possession, 247; present condition of, 24!).

Soutls ('arolina, its early polity, 125 ; temper at ontset of Ameriean levolution, 216.

Sonthey, his "arly enthusiasm for free iuleas, 2ul.

siatin, destruction of fromlom in, ltik; partially alophs .Inglo-saxon froedom, 角.

Stamp drt, colouies exasperaterl by, aki; delbate on, in Jarliament,

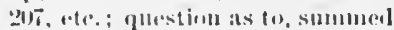
up, :211. :-11: importance of debatte ofl, to linglamd, 21:. 
Stanley, Dean, his "Memorials of Taylor, Hannis, his "Origin and Westminster Abbey" quoted, 76. Growth of the English Constitu-

Star-Chamber, Court of, its establishment and character, 101, 102; active under the Stuarts, 106. tion" citcd, 2, 50, 81, 121, 253, 256.

Tennessee, interested in public schools since the Civil War, 296.

States-General, in France, loses Tennyson, Alfred, his ode at openpower and disappears, 168.

Statute of Laborers, of 14 th century, 72,73 .

Stephen, King, sway of feudalism in his reign, 43.

Story, "On the Constitution," cited, 196. ing of the Colonial Exhibition, $1886,269$.

Texas, interested in public schools since Civil War, 296.

Thackeray, Rev. S. W., his "Land and the Community" cited, 83, 262.

Stoughton, on high character of the New England settlers, 214.

Strafford, Wentworth, Earl of, agent of absolntism of Charles I, 108; his execution, 132; Traill's Life of, referred to, 275 .

Stuarts, their incompetency as rulers, 105; general lack of manly and womanly worth, 173; abridge the franchise, 182.

Stubbs, his "Constitutional History"' cited, $2,42,48,49,52,58$, $60,95,100$.

Sudbury, illustrates abuses in borough representation, 184 .

Sugar Act, hardship of its operation in Thirteen Colonies, 200.

Supervisor, office of, in TownshipConnty system of local government, 126, 289.

Supporters of the Bill of Rights, Society of the, their democratic ideas, 223.

Supremacy, Act of, under Elizabeth, 100, 101.

Supreme Court of the United States, based on English precedents, 241.

Sweden, partially adopts AngloSaxon freedom, 271.

Tacitus, his "Germania" cited, 2.

Taillefer, the Norman minstrel at Hastings, story of, 32,33 .

Taswell-Langmead, his " English Constitutional History " cited, 2, $22,60,70,86,100$.

Thackeray, W. M., on mistake of England in the American Revolution, 349 .

Thegns, class of, originate from the Gesith, 19.

Theows, slaves of the Anglo-Saxons, 4.

Thomson, his "Historical Essay on Magna Charta" cited, 51.

Thorongh, policy of Laud and Strafford under Charles I, 108.

Tobacco, importance of, in determining the form of Virginia society, 123.

Tories, their origin and principles in England, 170; doubtfnl struggle with Whigs at opening of 18th century, 172; their connection with parliamentary corruption, 178; of America, their strength, 225 , etc.; their high position and character, $22 \pi$; pathetic circumstances of their exile, 228, etc.; in Eugland, favor in modern times self-government in colonies, 265.

Town-meeting of New England, analogous to ancient folk-moot, 9 ; early New England townmeeting, 117; not changed by the Revolution, 237; its present condition, 277, etc.; drawbacks of, 283 ; tributes to its value, 284.

Town-system of local self-government, described, 276 , etc.; carried by New Englanders to the West, 285. 
Township-County system of local self-government, its germ found in New York, 126; prevalent in Middle and Western States, 277 ; as found in Michigan, 289, 290; in Illinois, 292, 293; in Wisconsin, Nebraska, Ohio, Indiana, Missouri, Kansas, 293; in Iowa, Minnesota, the Dakotas, 294.

Traill, his "Life of Strafford" cited, 275.

Tucker, Dean, favors freedom of the Thirteen Colonies, 222.

Tudors, their arbitrary temper, 100 (why partially thwarted, 102); their masterful qualities, 105; create rotten boroughs, 182.

Tun, of the primitive Teutonic mark, 3 ; reprodnced to some extent in New England, 116.

Unification, a tendency toward, among modern nations, benefits from it to humanity and to the individual, 3i8, 36 \%

Uniformity, Act of, under Elizabeth, $100,101$.

United States, polity of, compared with that of Anglo-Saxons, 8, 9; germ to be found in early Teutonic communities, 10 ; adopt Federal Constitution, 235; base it on English precedents, 2ist; etc.; contrast between founders of, and those of other republics, $23 t ;$; stability of, due to great amonnt of Fingland imberded in them, 243; condition of moral population in, as regarls the popular moot, 2ist, etc.; Township-County system likely some day to become uniform type of local government in, 2:18; condlition of urban propulation in, rapid increase in size and mumber of cities not necessarily an evil, 2.4); government of cities the one rouspisuoms failure of, 300: people of, of undoubted AngloSaxon stock, :313; testimony 10 this of Mattlew Arnold, 314; of
R. A. Proctor, 314, 315; of Bryce, 315, 316; of Sir Edwin Arnold, 317,318 ; embarrassments of, at present moment, 323,324 ; indifference in, to idea of an AngloSaxon brotherhood, 348 .

Universities, English, almost uniformly hostile to political progress, 333.

University of Oxford, advocates absolutism under James 1, 105; dislike of liberty in, in present century, 333.

Vamberry, Arminius, on the colonial position of England, 357.

Vane, the writer's " Life of Young Sir Henry" eited, 139, 141, etc.; $145,154,155,162$.

Vane, Young Sir Henry, negotiates the Solemn Leaguc and Covenant, 138; not at first in favor of popular liberty, 145 ; condenus exeeution of Charles I, 150 ; quarrels with Cromwell, 159; his "Healing Question," '235.

Vietoria, Queen, at opening of the Colonial Exhibition in 1856,269 , 270.

Villeinage, origin of, 23; grades and charaeter of, under Norman Kings, 45; condition of, in 14th century, $70, \pi 1$.

Virginia, company, chartered, 16iot, beginning of English colonization of America, 111; development of polity in, 11s, ete.; reproluces contemporary England, 119; her parishes, vestries, comnties, and Courts of Quarter sessions, 11!, etc.; her condition in 18th century, 193: ecelesiastical gricrance in, 197; temper of, at ontset of American lievolution, 215; loc:al government in, since Civil War, 2:n;.

Voll Dlaurer, his "Mark-Yerfassung " rited, ".

Waitz, hiss " Dentsche V'rrassungsgeschichte" eited, "2. 
Walpole, Horace, on transferrence of the true English to America, 110 ; believes American Revolution saves English freedom, 222 . Walpole, Sir Robert, his connection with parliamentary corruption, 188.

Wapentake, name for hundred, 18. Washington, his position as compared with that of Wat Tyler and Jack Cade, 91 ; fears strength of the Tories in American Revolution, 226; celebration of centennial of his inauguration, April 30, 1889,327 .

Wat 'Tyler, leader of peasant rebellion in 1380,76 ; his death and character, 77.

Waterloo, battle of, brings cessation of reaction against French Revolution, 252.

Weser, scene at mouth of river, 2 .

West, settlement of the, in United States, 285.

West Indies, assured to England, 248 ; character of her dominion in, 249.

West Virginia, local government in, 297.

Westminster Review, The, on misappreciation of England by Anerica, 219; on India, 272; on an Englisl-speaking brotherhood, 345, etc.

Whigs, their origin and principles, 170; affiliated with nonconfornists and the commercial class, 171 ; doubtful struggle with Tories at beginning of 18tl century, 172; their connection with parliamentary corruption, 178; favor self-government in the colonies, 265.

Whitlocke, his "Memorials" cited, 147.

Wilkes, England roused from apatliy by case of, 189 .

William I (the Conqueror), lands at Hastings, 27 ; instance of his tact, 28; his generalship and bravery, 34 ; as a victor, 35 ; his character, 36 ; nature of his rule, 40; maintains a large portion of the old order, 41.

William II (Rufus), character of his rule, 43 .

William III (of Orange), his accession, 167 ; his eliaracter, 172, 173; stoops to bribery, 178 .

William IV, and Reform Bill of $1832,255$.

William Grindecobbe, heroic peasant in $1380,78$.

Wilson, Woodrow, cited, 353.

Windsor Castle, view from, 47.

Winsor, Justin, his " Narrative and Critical History of America " cited, 194, 220.

Winthrop, John, settles Boston, 116.

Wisconsin, local government in, 290, 293.

Witenagemote, origin of, 20 ; persists under the Norman Kings, 43 ; how developed into Parliament, 63.

Worcester, battle of, 1651, 158.

Wordsworth, his early enthusiasm for freedom, 251.

Writs of Assistance, Thirteen Colonies exasperated by, 205.

Wyatt's rebellion, against Mary Tudor, 99.

Yeomen, their rise, character, and position, 65; as settlers of New England, 121, 122; give strength to the Rommdheads in the Civil War, 134; their value as soldiers, 136; have an influence in electing knights-of-the-slire, history of their decline, 179; rapid in 18th century, 180; their revival anticipated, 311.

Yonge, his "Constitutional History of England "' cited, 211, 265.

Yorkshire freeholders, mass-meetings of, 189.

Zincke, F. Barham, on future greatness of the English-speaking race, 309 , etc. 



UNTVERSITY OF CALIFORNIA LIBRARY, LOS ANGELES

\section{COLLEGE LIBRARY}

University of Calliomia

SOUTHERN REGIONAL LBRARY FACIUTY

405 Hiligard Avenue, Los Angeles, CA $90024-1388$

Retum this material to the library from which in was borrowed.

$A \cup G$

Colles

iery 


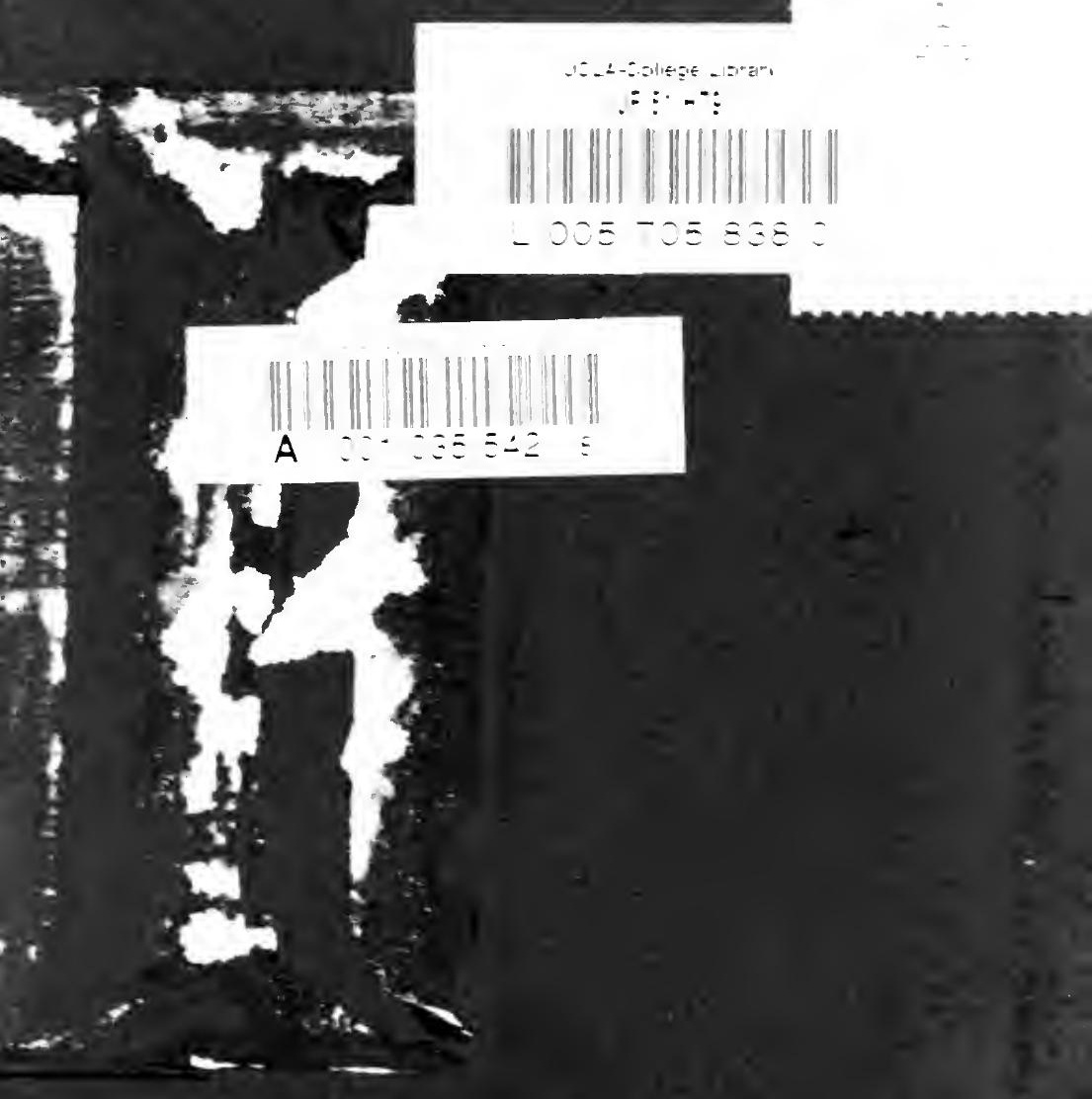




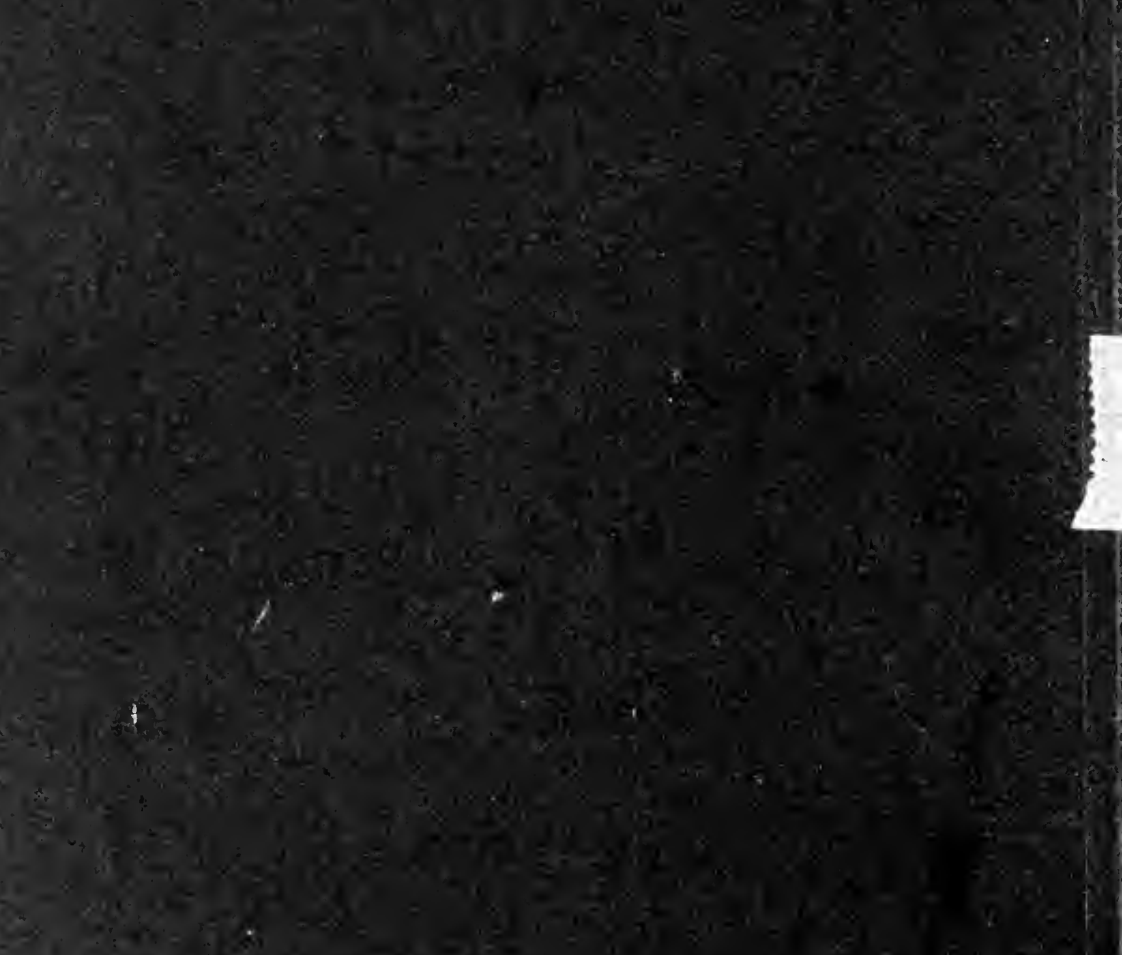

$x$

$\frac{3}{3}$ 